\title{
4 FERNALD
}

$$
\text { FEMP-25/8 }
$$

1995

SITE ENVIRONMENTAL REPORT
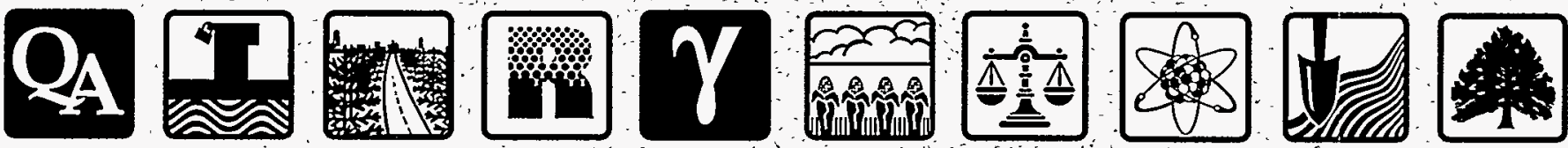

U.S. DEPARTMENT OF ENERGY FERNALD FIELD OFFICE CONTRACT

$D E-A C 24-920 R 21972$

JUNE 1996

DISTRIBUTION OF THIS DOCUMEVT IS UMIMTED

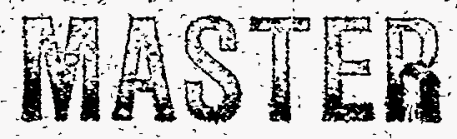

BY THE SITE RESTORATION SERVICES DEPARTMENT FERNALD ENVIRONMENTAE RESTORATION MANAGEMENT CORPORATION 
Ohio Field Office

Fernald Area Office

P. O. Box 538705

Cincinnati, Ohio $45253-8705$

(513) 648-3155

TOCT 311996

DOE-0015-97

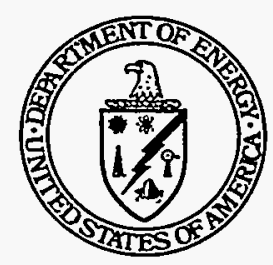

Dear Fernald Stakeholder:

\section{SUPPLEMENTAL ADDENDUM TO THE 1995 SITE ENVIRONMENTAL REPORT}

Enclosed for your information and reference is an addendum to the Fernald Environmental Management Project's 1995 Site Environmental Report. This addendum clarifies errors which were not identified during the final editing stage of the report.

The addendum comprises the following:

- $\quad$ Shaded text in reference to changes in the Executive Summary and in Chapter 5;

- Figure 43 in Chapter 6 has been footnoted to explain the change in units reported;

- Changes to Tables 11 and 17, found in Appendix A, have been highlighted for easy reference; and,

- Table 31, Fernald - OEPA Sampling Comparison, has been added for reference to surface water sampling for uranium and radium.

Please insert the enclosed addendum pages into the 1995 Site Environmental Report.

Please accept my sincere apology for any inconvenience or confusion these errors may have caused. If you have any questions regarding the addendum or the 1995 Site Environmental Report, please contact Kathi Nickel at (513) 648-3166.

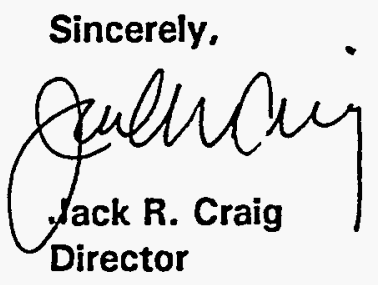

FEMP:Nickel

Enclosure: As Stated 
P. O. Box 538705

Cincinnati, Ohio 45253-8705

(513) $648-3155$

ALP 171996

DOE-1362-96

Dear Fernald Stakeholder:

\section{ADDENDUM TO THE 1995 SITE ENVIRONMENTAL REPORT}

The recently issued 1995 Site Environmental Report and companion summary booklet incorrectly identified the 1995 estimated dose to the maximally-exposed individual as 0.1 millirem (mrem). The correct estimated dose to the maximally-exposed individual was $\mathbf{1 . 0}$ mrem. This dose represents approximately one percent of the U.S. Department of Energy (DOE) guideline of $100 \mathrm{mrem}$ per year from all pathways. Please note this correction in the 1995 Site Environmental Report Executive Summary, Page XV; Chapter Seven, Estimated Radiation Doses for 1995, Page 143; and the 1995 Site Environmental Report Summary booklet, Page 11.

We apologize for any inconvenience this may have caused. If you have any questions regarding this report, please contact Kathi Nickel at (513) 648-3166.

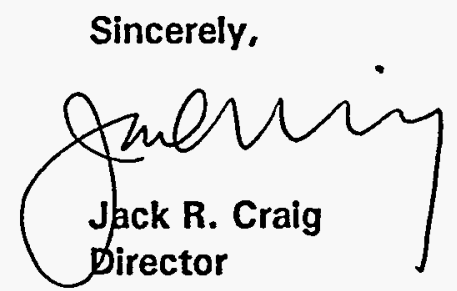

FEMP:Nickel

(2) Recycled and Recyclable 


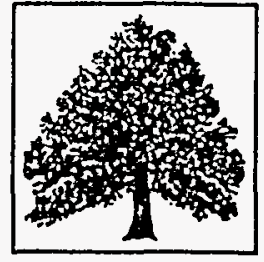

Department of Energy

Ohio Field Office

Fernald Area Office

P. O. Box 538705

Cincinnati, Ohio $45253-8705$

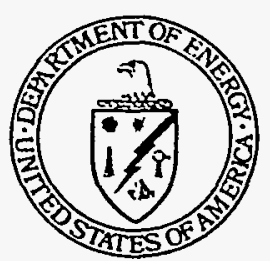

(513) 648-3155

SEP Q 9 ISSO

DOE-1302-96

Dear Fernald Stakeholder:

\section{SITE ENVIRONMENTAL REPORT}

Enclosed for your information and reference is the Fernald Environmental Management Project's 1995 Site Environmental Report. This report presents results from the environmental monitoring conducted during 1995 as well as a summary of the site's compliance status during the year.

This Site Environmental Report was prepared by Fernald Environmental Restoration Management Corporation (FERMCO) for the Department of Energy, Fernald Area Office (DOE-FN). Both organizations have reviewed the document to ensure that valid and accurate environmental monitoring data are reported. This report is distributed to local, state and federal agencies; Congress; the public; and the media.

If you have any questions regarding this report, please contact Johnny Reising at (513) 648-3139.

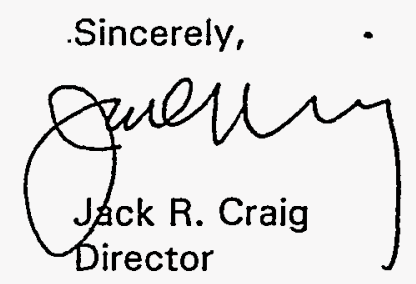

FN: Reising

Enclosure: As Stated 
$\therefore+8$

FEMP-2518

SPECIAL

UC-707

\section{5}

\section{SITE ENVIRONMENTAL REPORT}

Prepared for

U.S. Department of Energy

Fernald Field Office

CONTRACT DE - AC24 - 92 OR21972

Prepared bY

Site Restoration Services Department

Fernald Environmental Restoration Management Corporation 
Notice This report was prepared as an account of work sponsored by an agency of the United States government. Neither the United States government or any agency thereof, nor any of their employees, nor any of its contractors, subcontractors nor their employees, make any warranty, expressed or implied, or assume any legal liability or responsibility for the accuracy, completeness, or usefulness of any information, apparatus, product, or process disclosed, or represent that its use would not infringe privately owned rights. Reference herein to any specific commercial product, process, or service by trade name, manufacturer or otherwise, does not necessarily constitute or imply its endorsement, recommendation, or favoring by the United States government or any agency thereof. The views and opinions of authors expressed herein do not necessarily state or reflect those of the United States government or any agency thereof, or Fernald Environmental Restoration Management Corporation, its affiliates or its parent companies.

This report has been reproduced from the best available copy.

Available to DOE and DOE contractors from:

The Office of Scientific and Technical Information

P.O. Box 62

Oak Ridge, TN 37831

Prices available from (615) 576-8401, FTS 626-8401.

Available to the public from:

The National Technical Information Service

U.S. Department of Commerce

5285 Port Royal Road

Springfield, VA 22161

Printed Copy Price: A11

Microfiche Price: A01

(3)

This document was reproduced on recycled and recyclable paper. 


\section{DESCLAMVIRR}

Portions of this document may be allegible in electronicinage products. Images are produced from the best avallable coriginal document. 


\section{DISCLAIMER}

This report was prepared as an account of work sponsored by an agency of the United States Government. Neither the United States Government nor any agency thereof, nor any of their employees, make any warranty, express or implied, or assumes any legal liability or responsibility for the accuracy, completeness, or usefulness of any information, apparatus, product, or process disclosed, or represents that its use would not infringe privately owned rights. Reference herein to any specific commercial product, process, or service by trade name, trademark, manufacturer, or otherwise does not necessarily constitute or imply its endorsement, recommendation, or favoring by the United States Government or any agency thereof. The views and opinions of authors expressed herein do not necessarily state or reflect those of the United States Government or any agency thereof. 


\section{Table of Contents}

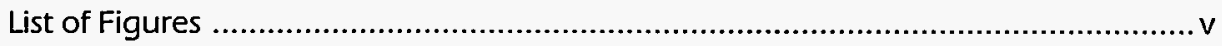

List of Tables ......................................................................................................... vi

Acronyms and Abbreviations ...................................................................... vii

Conversion Tables .................................................................................

\section{Executive Summary}

Environmental Monitoring ................................................................................ xii

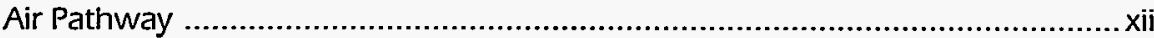

Radon Monitoring ................................................................................ xiii

Liquid Pathway: Effluent and Surface Water ................................................

Liquid Pathway: Groundwater ........................................................... xiv

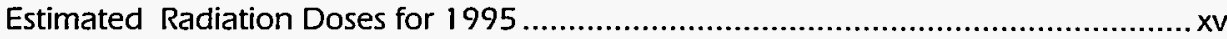

Dose Attributable to Radon ................................................................ XV

Chapter 1 - Introduction to the Site 1

The Fernald Site Mission: Environmental Compliance and Restoration ....................... 2

An Overview of Former Production Operations ............................................ 2

Handling and Storing Radioactive and Hazardous Materials ........................... 4

Environmental Restoration Activities ...................................................... 8

UNH Neutralization Project ....................................................... 8

Vitrification Pilot Plant ..................................................................... 9

Thorium Nitrate Stabilization ............................................................... 9

Plant 4 Decontamination \& Decommissioning (D\&D) ........................... 9

Environmental Program Information ............................................................. 10

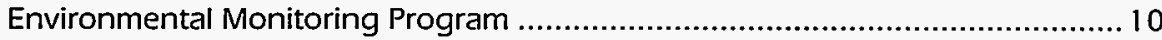

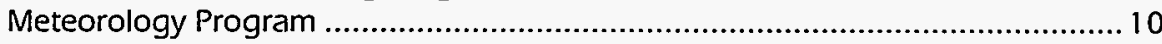

Waste Minimization Program .................................................................. 13

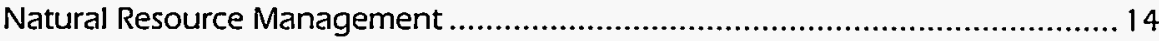

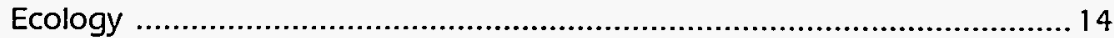

Threatened and Endangered Species ................................................... 15

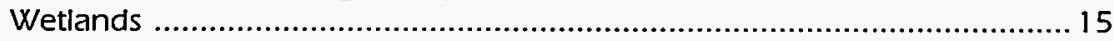

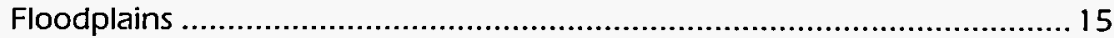

Cultural Resources ........................................................................ 15

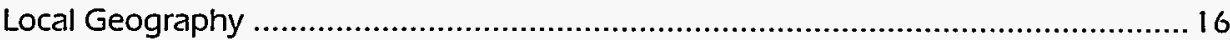

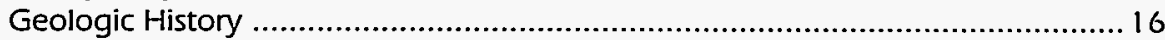

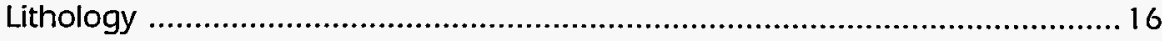

Groundwater Hydrology ................................................................. 18

Surface Hydrology ................................................................................... 19

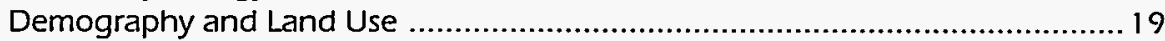

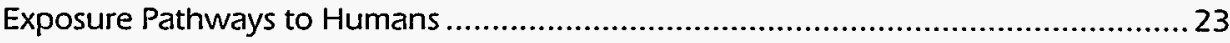

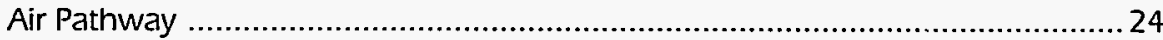

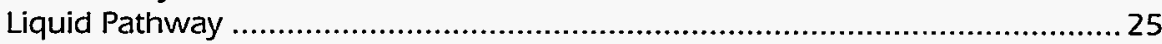

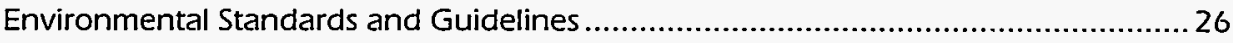

Chapter 2 - Fundamentals of Radiation and Health Hazards $\quad 29$

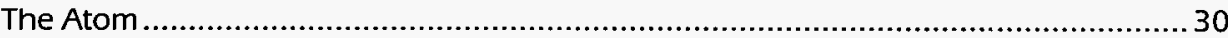

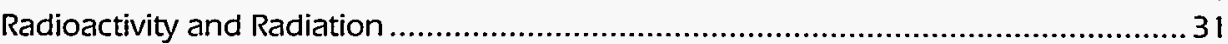

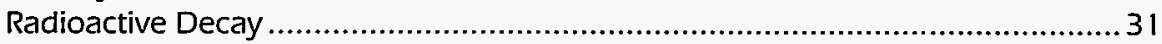

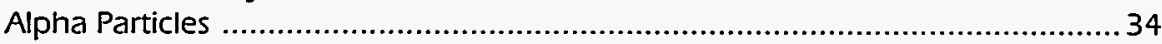

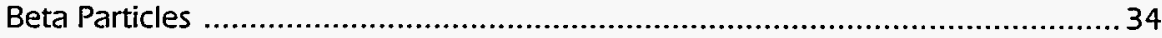

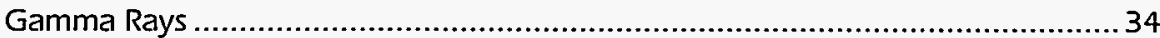

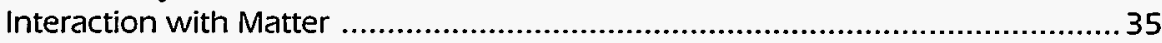

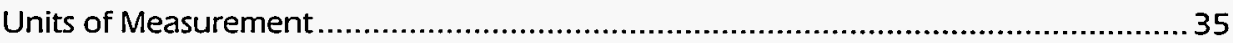

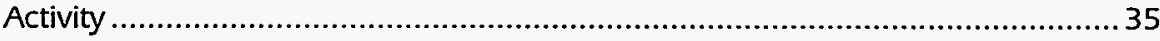

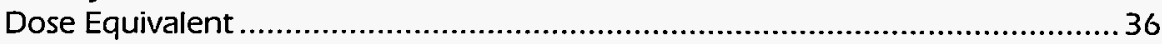




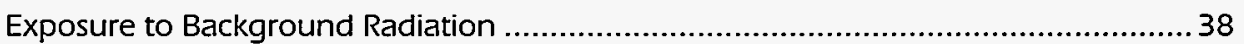

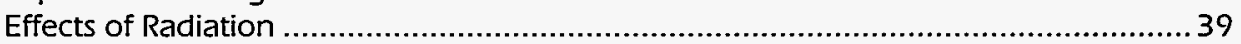

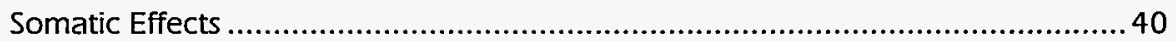

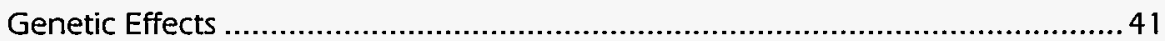

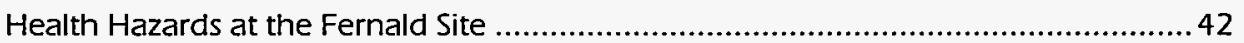

Definitions of Terms ............................................................................ 42

Laws Regulating Health Hazards ..................................................................... 43

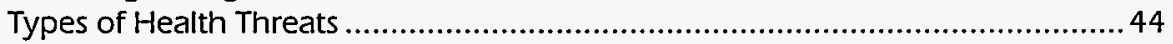

$\begin{array}{ll}\text { Chapter } 3 \text { - Environmental Compliance Summary } & 47\end{array}$

Compliance Status .................................................................................. 48

Comprehensive Environmental Response, Compensation, and Liability Act .......48

Superfund Amendments and Reauthorization Act ..................................50

Resource Conservation and Recovery Act ......................................... 52

Federal Facility Compliance Act ............................................................ 53

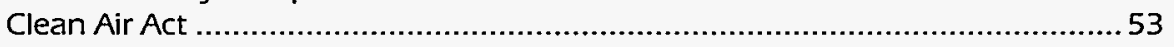

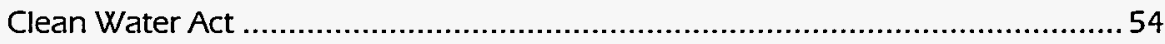

NPDES Effluent Regulation ............................................................. 54

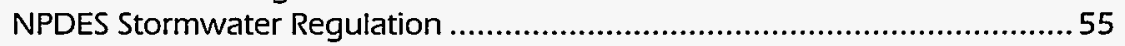

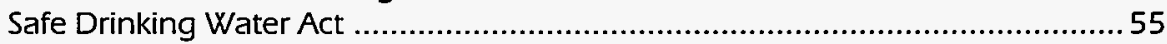

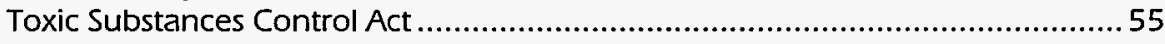

Ohio Solid Waste Act ...................................................................... 57

Federal Insecticide, Fungicide, and Rodenticide Act ................................... 57

National Environmental Policy Act ......................................................... 57

Endangered Species Act ................................................................. 58

10 CFR 1022 - Compliance with Floodplain/Wetlands Review Requirements .... 59

Executive Order 12898, "Federal Actions to Address

Environmental Justice in Minority and Low-income Populations" ...................59

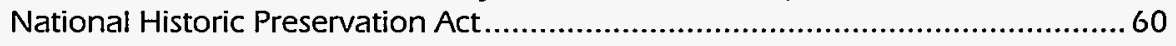

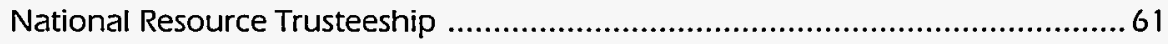

Major Accomplishments and Issues ......................................................61 61

Comprehensive Environmental Response, Compensation, and Liability Act .......61

OU1 Record of Decision Signed in March 1995 .....................................62 62

Dewatering Excavation Evaluation Program (DEEP) ..............................6 62

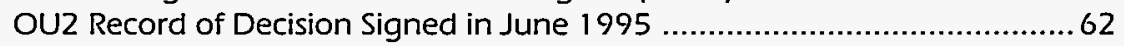

OU3 Record of Decision for Interim Remedial Action Signed in July 1994 ...64

OU3 Remedial Investigation, Treatability Studies, and Feasibility Study ........ 64

OU4 Remedial Design Work Plan Approved in June $1995 \ldots \ldots \ldots \ldots \ldots \ldots \ldots \ldots . . . . .65$

Vitrification Pilot Plant .......................................................................65 65

OU5 Feasibility Study/Proposed Plan and Record of Decision .....................65 65

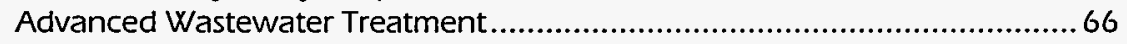

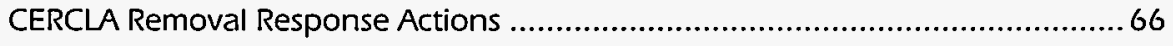

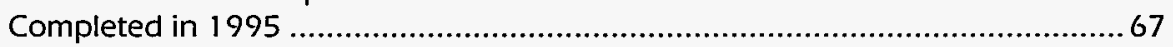

Removal Action No. 1 - Contaminated Water Beneath FEMP Buildings .......67 67

Removal Action No. 30 - Seepage Control

at the South Field and Inactive Flyash Pile ........................................6 67

Removal Actions Ongoing (Excluding Combined RCRAVCERCLA Activities) .........67

Removal Action No. 3 - South Groundwater Contamination Plume ............667

Removal Action No. 9 - Removal of Waste Inventories .........................67

Removal Action No. 12 - Safe Shutdown .............................................68 68

Removal Action No. 15 - Scrap Metal Piles ............................................68 68

Removal Action No. 17 - Improved Storage of Soil and Debris ........................68

Removal Action No. 26 - Asbestos Removals ...................................... 70

Resource Conservation and Recovery Act ................................................ 70

Stipulated Amendment to Consent Decree (SACD) ....................................70

Changes/Additions to Wastestreams in 1995 Facility RCRA Annual Report ... 70

Thorium Management ................................................................... 71

RCRA Closures .............................................................................. 71

RCRA Routine Groundwater Monitoring

Program - Director's Final Findings and Orders .................................. 73 
Removal of Site Product Inventories ........................................................ 73

Safety \& Health Self-Assessment Program ..................................................... 74

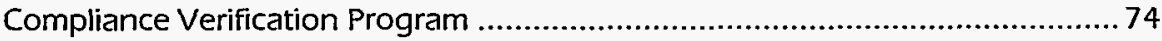

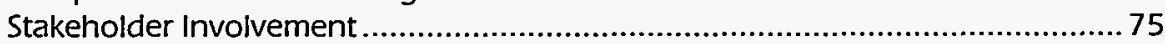

DOE Complex-wide Performance Indicator Status ....................................... 76

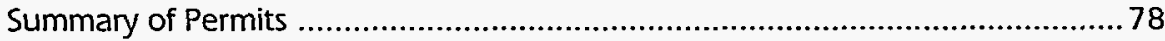

$\begin{array}{ll}\text { Chapter } 4 \text { - Air Pathway Monitoring } & 79\end{array}$

Monitoring for Radioactive Pollutants ...................................................... 81

Air Sampling for Radioactive Particulates .............................................. 81

Monitoring Plant $1 \&$ Plant 4 Decontamination \& Decommissioning ...................86 86

Soil Sampling for Uranium ........................................................................ 86

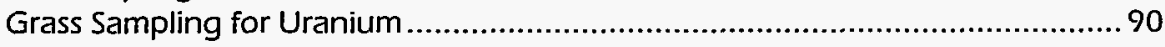

Produce Sampling for Uranium ............................................................ 91

Milk Sampling for Radionuclides ............................................................... 93

Beef Cattle Sampling for Radionuclides ................................................. 93

Monitoring for Direct Radiation ........................................................... 94

Monitoring for Nonradioactive Pollutants .................................................. 94

Chapter 5 - Liquid Pathway: Effluent and Surface Water Monitoring 97

Monitoring for Radioactive Pollutants .............................................................. 98

Effluent Sampling for Radionuclides .................................................. 98

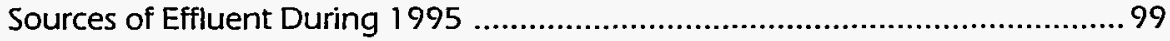

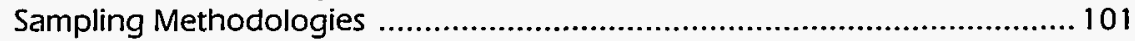

Results of Laboratory Analyses .......................................................... 103

Surface Water Sampling for Radionuclides ................................................ 104

Sampling Methodologies .............................................................. 104

Results of Laboratory Analyses ......................................................... 106

Sediment Sampling for Radionuclides ....................................................... 107

Sampling Methodologies .............................................................. 107

Results of Laboratory Analyses .......................................................... 109

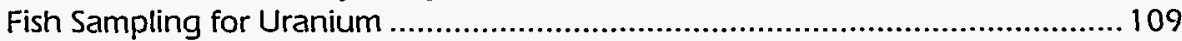

Sampling Methodologies .............................................................. 109

Results of Laboratory Analyses ............................................................ 111

Monitoring for Nonradioactive Pollutants ........................................................ 111

Chapter 6 - Liquid Pathway: Groundwater Monitoring 113

History of Groundwater Monitoring at the Site................................................... 114

Fernald Site Groundwater Remedy .............................................................. 119

Routine Groundwater Monitoring Activities for 1995 .......................................119

Radiological Environmental Monitoring (Private Well) Program ....................... 120

RCRA Groundwater Monitoring Program ................................................. 123

South Plume Removal Action Monitoring Program ....................................... 124

KC-2 Warehouse Well Monitoring Program ............................................. 127

Coal Pile Runoff Basin Monitoring Program ............................................. 127

Additional Groundwater Activities for 1995 ....................................................... 129

On-Site Disposal Facility (OSDF) Predesign Monitoring Program ...................... 129

Perched Groundwater Water Removal Action Monitoring .............................. 130

Public Water Supply Program .................................................................... 132

Archeological Findings ............................................................... 132

Establishing a Site Comprehensive Environmental Monitoring Program ............. 133

$\begin{array}{ll}\text { Chapter } 7 \text { - Estimated Radiation Doses for } 1995 & 135\end{array}$

Methodology for Calculating Total Radiation Dose ........................................ 136

Environmental and Dose Modeling ............................................................ 136

Air Pathway Dose Calculations ................................................................ 137

Estimated Doses from Airborne Emissions ................................................ 137

Estimated Dose from Eating Foodstuffs Produced near the Fernald Site............ 139

Direct Radiation Dose ........................................................................ 140 
Liquid Pathway Dose Calculations

Estimated Dose from Drinking Well Water

in the Area around the Fernald Site

Estimated Dose from Drinking Great Miami River Water .............................. 142

Estimated Dose from Eating Fish from the Great Miami River ......................... 142

Total of Doses to a Maximally-Exposed Individual .................................................. 142

Significance of Estimated Radiation Doses for 1995 ......................................... 143

$\begin{array}{lr}\text { Chapter } 8 \text { - The Radon Monitoring Program } & 145\end{array}$

Introduction to Environmental Radon ........................................................... 146

The Radon Monitoring Program at Fernald .................................................... 148

Long-term, Time-integrating Radon Monitoring ......................................... 148

Routine Long-term Monitoring .............................................................. 149

Continuous Radon Monitoring ............................................................ 149

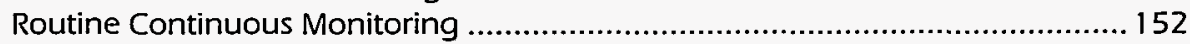

Special Project Monitoring ........................................................................ 152

1995 Environmental Radon Monitoring Results ........................................ 154

Uncertainties With Environmental Measurements ........................................ 154

Quality Assurance of the Radon Monitoring Program ........................................ 155

Estimated Fenceline Radiation Dose from Radon ........................................ 157

$\begin{array}{ll}\text { Chapter 9 - Quality Assurance for the Environmental Monitoring Program } & 159\end{array}$

Sitewide CERCLA Quality Assurance Project Plan .............................................. 160

Data Quality Objectives ................................................................ 160

Quality Assurance: Field Activities ................................................................. 160

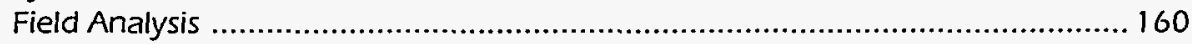

Field Documentation .................................................................. 161

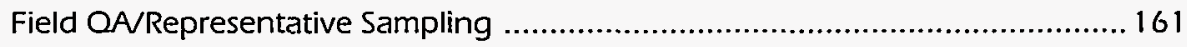

Sample Custody ............................................................................... 162

Analytical Laboratory Quality Assurance ........................................................ 162

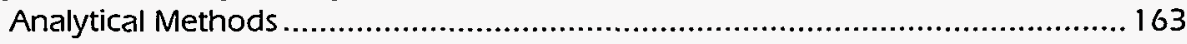

Analytical Performance ..................................................................... 163

Detection of Data Problems and Corrective Action ..................................... 163

Independent Evaluations of the Fernald Site Laboratories ................................. 164

DOE's Environmental Measurements Laboratory ...................................... 164

USEPA's Discharge Monitoring Report .................................................... 164

Commercial Proficiency Environmental Testing ....................................... 165

Split Sampling Program ................................................................... 165

Contract Laboratory Quality Assurance ................................................... 166

\section{Appendices}

Appendix A - Fernald Site Environmental Monitoring Data for 1995 ..................... A - 1

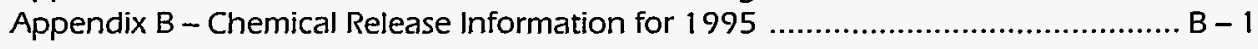

Appendix C - Fernald Site Removal Action Summary ..................................... C - 1

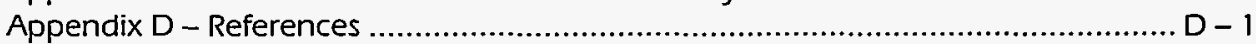

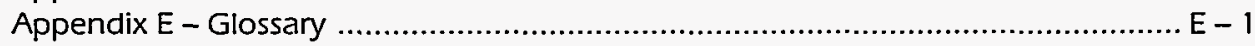




\section{List of Figures}

1

2

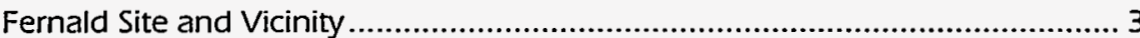

Former Site Production Process .............................................................. 5

Fernald Site Perspective ......................................................................... 6

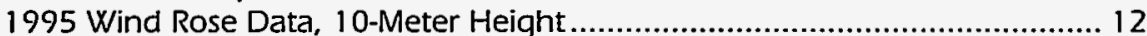

1995 Wind Rose Data, 60-Meter Height..................................................... 12

Annual Precipitation Data, 1985 - 1995 ...................................................... 13

Cross-Section of the New Haven Trough, Looking North ............................... 17

Buried Valley Aquifer Underlying the Fernald Site and Vicinity ........................ 20

Great Miami River Drainage Basin .................................................................. 21

Major Communities in Southwestern Ohio .................................................... 22

General Air Pathways to Humans ............................................................ 24

General Liquid Pathways to Humans ...................................................... 25

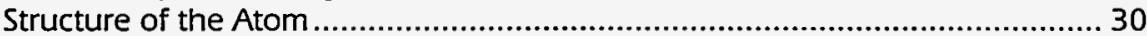

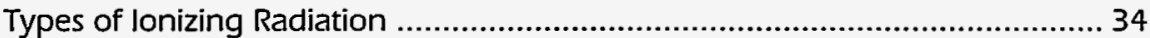

Comparison of Disintegration Rate ............................................................. 35

Organs Affected by Substances Found at the Fernald Site ............................... 37

Exposure to Background Radiation ............................................................. 38

Breakdown of Average U.S. Radiation Exposures ............................................ 39

Fernald Remediation .................................................................................. 51

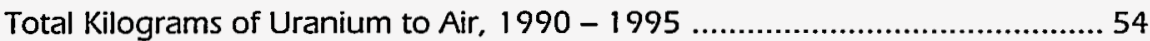

NPDES Effluent and Stormwater Monitoring Locations ................................... 56

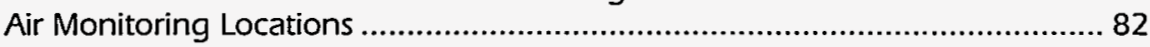

Average Uranium Concentrations in Air, $1991-1995$................................... 84

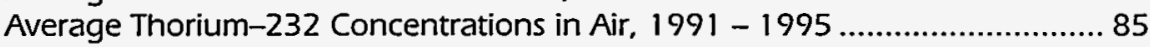

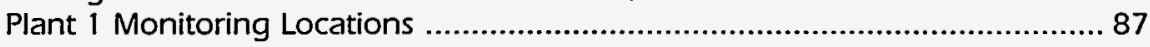

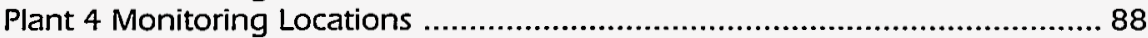

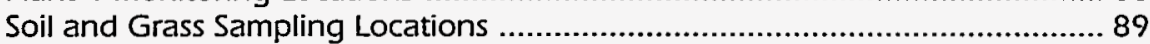

Range of Total Uranium Occurring in Surface Soils ....................................... 90

Produce Sampling Locations ................................................................ 92

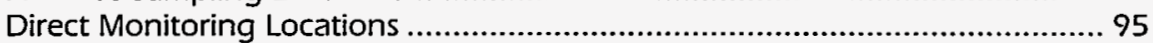

Fernald Site Effluent Flow Diagram ............................................................... 100

Area of Controlled Stormwater Runoff .................................................. 102

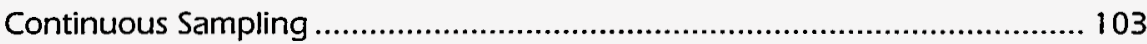

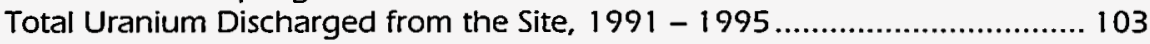

Surface Water Sampling Locations ......................................................... 105

Average Uranium Concentrations in Surface Water, 1991 - $1995 \ldots \ldots \ldots \ldots \ldots \ldots . . . .1106$

Sediment Sampling Locations ...................................................................... 108

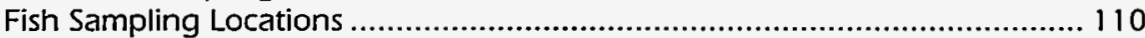

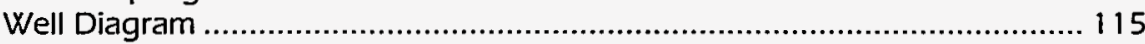

Areas of the Great Miami Aquifer Requiring Remediation ............................ 117

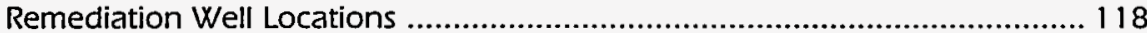

Private Well Monitoring Locations .......................................................... 121

Average Uranium Concentrations in Private Wells, $1991-1995$................... 122

South Plume Removal Action Monitoring and Pumping Wells ....................... 125

RCRA, KC-2 Warehouse and Coal Pile Runoff Monitoring Locations ............... 128

Location for the Onsite Disposal Facility ....................................................... 131

Department of Energy Dose Limits ......................................................... 139

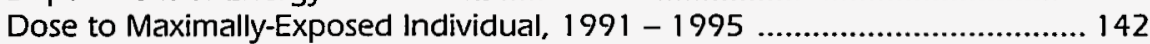

Decay Chains ..................................................................................... 147

Selected Offsite and Fenceline Radon Monitoring Locations ........................ 150

Onsite Passive Environmental Radon Monitoring Locations Near the Silos .... 151

Selected Continuous Radon Monitoring Locations ....................................... 153

Measurement Uncertainity .................................................................... 155 


\section{List of Tables}

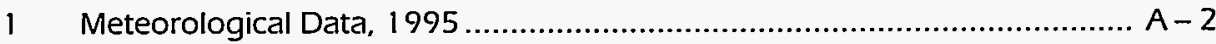

2 Estimated Population Distribution within $80 \mathrm{~km}$ (50 miles)

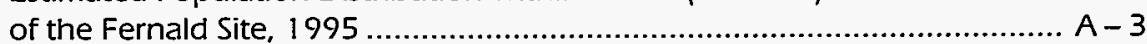

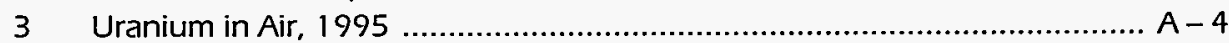

4 Radionuclides in Air, 1995 ................................................................. A

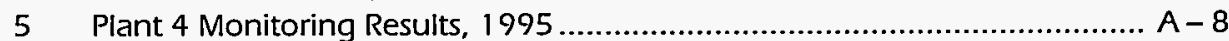

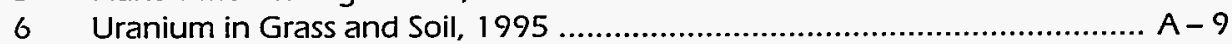

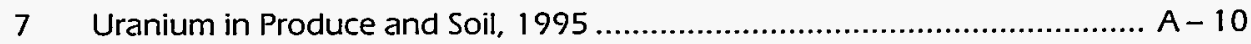

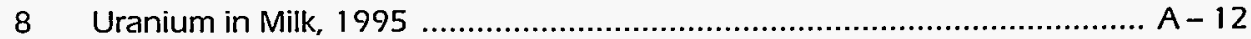

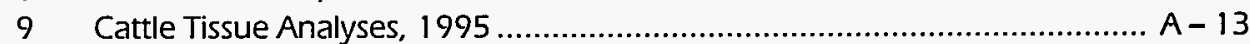

10 Environmental TLD Direct Radiation Measurements, $1995 \ldots \ldots \ldots \ldots \ldots \ldots \ldots \ldots . . . . . . . . . . . . . . .14$

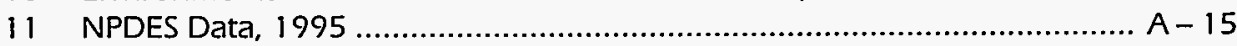

12 Radionuclides Discharged to the Great Miami River, 1995 ......................... A - 18

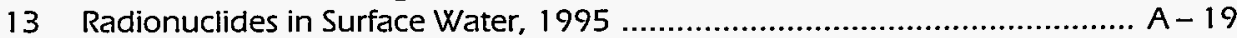

14 Radionuclides in Great Miami River, Paddys Run, and Storm Sewer Outfall Ditch Sediments, 1995 .................................... A -21

15 Uranium Concentrations in Fish from the Great Miami River, 1995 ............. A - 22

16 A NPDES Noncompliance Summary, 1995 ................................................ A - 23

$16 B$ Gross Alpha Data Greater than or Equal to

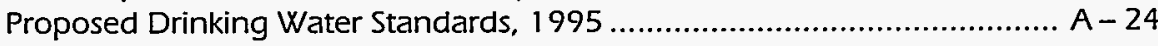

17 Uranium in Private Wells, 1995 ............................................................ A - 25

18 Summary Statistics and Trend Analysis for Routine Monitoring Program Wells Constituent Concentrations Above Final Remediation Levels, 1988-1995 Data ................................. A - 26

19 Comparison with Background and Statistical Means of Nine Constituents with Results Above Final Remediation Levels (FRLS), 1988-1995 ............... A - 30

20 Comprehensive Groundwater Samples with Uranium Concentrations

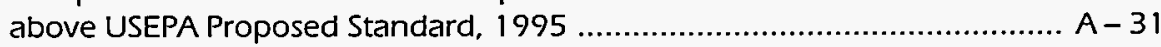

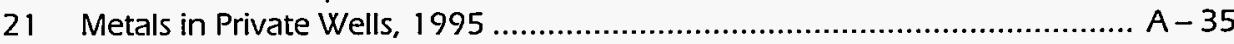

22 Nonradioactive Substances above Primary Drinking Water Standards, 1995 ...................................... A - 38

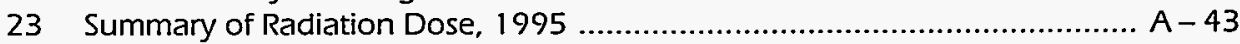

24 Estimated Airborne Emissions for the Fernald Site, 1995 .......................... A - 44

25 Radon in Air, 1995 ........................................................................ A - 45

26 DOE Quality Assessment Program for Environmental Radionuclide Analyses Fernald Site Laboratories Performance Results, 1995 ..................... A - 46

27 USEPA Quality Assurance Program for Wastewater Analyses Fernald Site Laboratories Performance Evaluation, 1995 ........................... A - 47

28 Proficiency Environmental Testing

Quality Assurance Program for Water Analyses, 1995 .............................. A - 48

29 Fernald Site - OEPA Sampling Comparison, $1995 \ldots \ldots \ldots \ldots \ldots \ldots \ldots \ldots \ldots \ldots \ldots . . . . . . . . . . . \ldots-50$

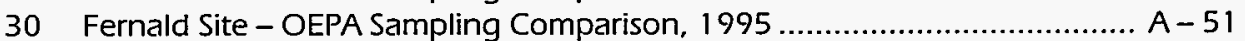




\section{Acronyms and Abbreviations}

ACA Amended Consent Agreement

AEC Atomic Energy Commission

AHF Anhydrous Hydrogen Fluoride

AIRDOS EPA Dose Model: AIRDOS-EPA (MO-79)

ALARA As Low As Reasonably Achievable

AMS Air Monitoring Station

ANSI American National Standards Institute

ARAR Applicable or Relevant and Appropriate Requirement

ASER Annual Site Environmental Report

AwwT Advanced Wastewater Treatment

BAT Best Available Technology

BDN Biodenitrification Facility

BMP Best Management Practices

BRA Baseline Risk Assessment

BSL Biodenitrification Surge Lagoon

CAA Clean Air Act

CERCLA Comprehensive Environmental

Response, Compensation, and

Liability Act

CFR Code of Federal Regulations

Ci Curie

Co Carbon Monoxide

CPID Closure Plan Information and Data

csou Comprehensive Sitewide Operable

Unit

CWA Clean Water Act

CX Categorical Exclusion

D\&D Decontamination and Dismantling

DCG Derived Concentration Guideline

DE Drum Equivalent

DFO Director's Final Findings and Orders

DOE Department of Energy

DQO Data Quality Objective

EA Environmental Assessment

EDE Effective Dose Equivalent

EIS Environmental Impact Statement

EM Environmental Monitoring

EML Environmental Measurements Laboratory

ESA Endangered Species Act

ES\&H Environment, Safety, and Health

ETS Effluent Treatment System

FACA Federal Advisory Committee Act

FEMP Fernald Environmental Management Project

FERMCO Fernald Environmental Restoration Management Corporation

FFCA Federal Facility Compliance Agreement

FFCAct Federal Facility Compliance Act
FIFRA Federal Insecticide, Fungicide, and Rodenticide Act

FMPC Feed Materials Production Center

FONSI Finding of No Significant Impact

FRL Final Remediation Level

FS Feasibility Study

FS/PP Feasibility Study/Proposed Plan

GQAPP Groundwater Quality Assessment

Program Plan

HSL Hazardous Substances List

HWMU Hazardous Waste Management Unit

IAWw Interim Advanced Wastewater

Treatment

ICRP International Commission on

Radiological Protection

IROD Record of Decision for Interim

Remedial Action

LDR Land Disposal Restriction

MCL Maximum Contaminant Level

$\mu \mathbf{C i}$ microcurie

mrem millirem

NAAQS

NCP

National Ambient Air Quality

Standards

National Oil and Hazardous

Substances Pollution Contingency

Plan

NCRP National Council on Radiation

Protection and Measurements

NEPA

NESHAP

National Environmental Policy Act

National Emission Standards for

Hazardous Air Pollutants

NOD Notice of Deficiency

NON Notice of Noncompliance

NOV Notice of Violation

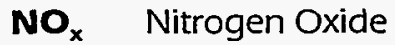

NPDES National Pollutant Discharge

Elimination System

NPL National Priorities List

NRC National Response Center

NRC Nuclear Regulatory Commission

NTS Nevada Test Site

OAC Ohio Administrative Code

ODH Ohio Department of Health

OEPA Ohio Environmental Protection

OHPO Ohio Historic Preservation Office

ORNL Oak Ridge National Laboratory

ORO Oak Ridge Operations

OSHA Occupational Safety and Health

Administration

ou Operable Unit

PCB Polychlorinated Biphenyls

PCi picocurie 


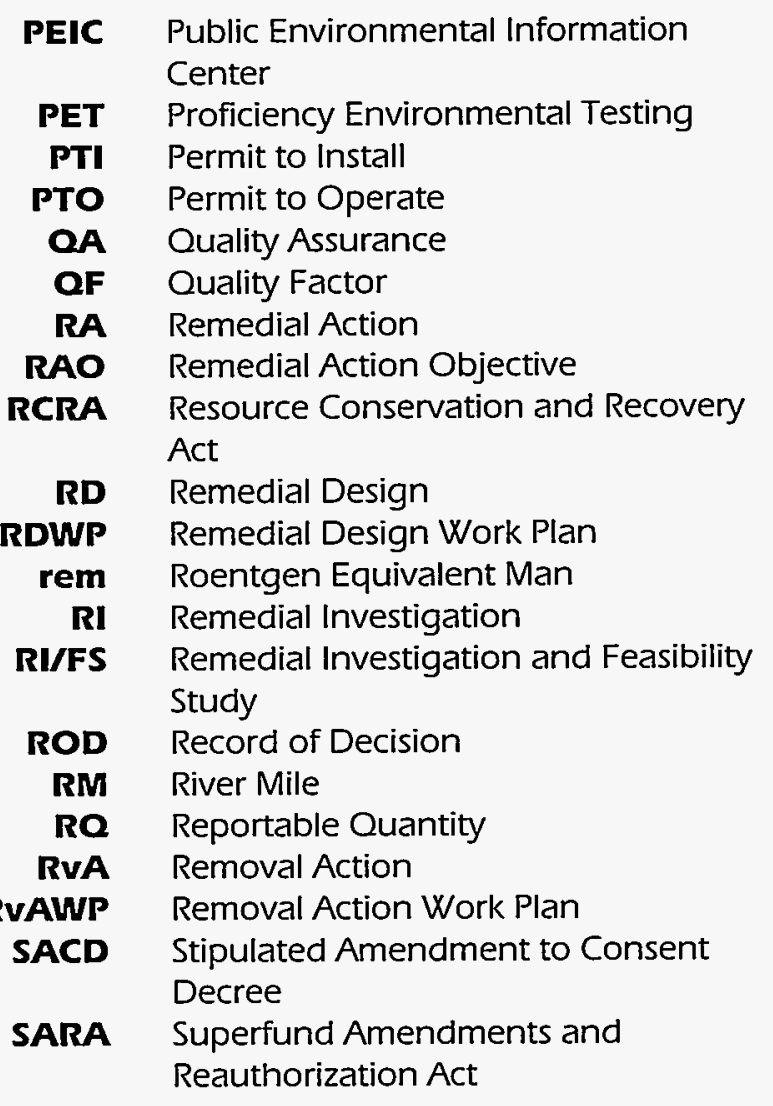

SCO Sitewide CERCLA Quality Assurance Project Plan

SDWA Safe Drinking Water Act

SER Site Environmental Report

SERC State Emergency Response Commission

SHPO State Historic Preservation Officer

$\mathrm{SO}_{2}$ Sulfur Dioxide

SPCC Spill Prevention Control and Countermeasure

SSOD Storm Sewer Outfall Ditch

SU Standard Units

SWMU Solid Waste Management Unit

SWRB Stormwater Retention Basin

TLD Thermoluminescent Dosimeter

TSCA Toxic Substances Control Act

TSDF Treatment, Storage, and Disposal Facility

UNH Uranyl Nitrate Hexahydrate

USEPA U.S. Environmental Protection Agency

voc Volatile Organic Compounds

WEMCO Westinghouse Environmental Management Company of Ohio

WM/PP Waste Minimization/Pollution Prevention 


\section{Conversion Tables}

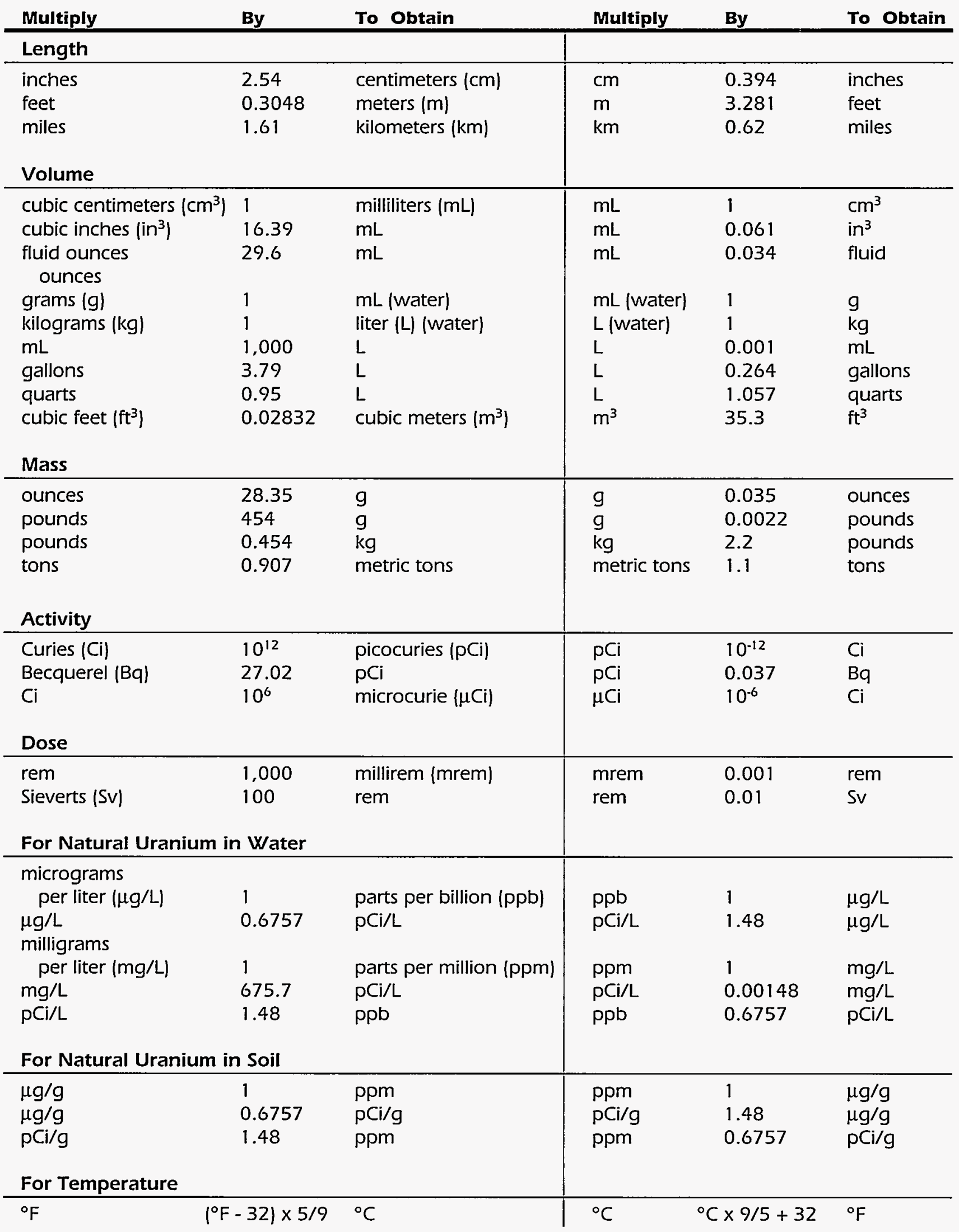




\begin{tabular}{|lrll|}
\hline Multiple & Decimal Equivalent & Prefix & Symbol \\
\hline $10^{6}$ & $1,000,000$ & mega- & $\mathrm{M}$ \\
$10^{3}$ & 1,000 & kilo- & $\mathrm{k}$ \\
$10^{2}$ & 100 & hecto- & $\mathrm{h}$ \\
10 & 10 & deka- & $\mathrm{da}$ \\
$10^{-1}$ & 0.1 & deci- & $\mathrm{d}$ \\
$10^{-2}$ & 0.01 & centi- & $\mathrm{c}$ \\
$10^{-3}$ & 0.001 & milli- & $\mathrm{m}$ \\
$10^{-6}$ & 0.000001 & micro- & $\mu$ \\
$10^{-9}$ & 0.000000001 & nano- & $\mathrm{n}$ \\
$10^{-12}$ & 0.000000000001 & pico- & $\mathrm{p}$ \\
$10^{-15}$ & 0.000000000000001 & femto- & $\mathrm{f}$ \\
$10^{-18}$ & 0.000000000000000001 & atto- & $\mathrm{a}$ \\
& & & \\
\hline
\end{tabular}


EXECUTIVE
SUMMARY

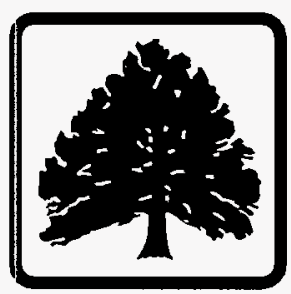




\section{Executive Summary}

The Fernald site is a Department of Energy (DOE)-owned facility that produced high-quality uranium metals for military defense for nearly 40 years. DOE suspended production at the site in 1989 and formally ended production in 1991. Although production activities have ceased, the site continues to examine the air and liquid pathways as possible routes through which pollutants from past operations and current remedial activities may leave the site.

The Site Environmental Report (SER) is prepared annually in accordance with DOE Order 5400.1, General Environmental Protection Program. This 1995 SER provides the general public as well as scientists and engineers with the results from the site's ongoing Environmental Monitoring Program. Also included in this report is information concerning the site's progress toward achieving full compliance with requirements set forth by DOE, U.S. Environmental Protection Agency (USEPA), and Ohio EPA (OEPA).

For some readers, the highlights provided in this Executive Summary may provide sufficient information. Many readers, however, may wish to read more detailed descriptions of the information than those which are presented here. All information presented in this summary is discussed more fully in the main body of this report. 


\section{Environmental Monitoring}

The Fernald Environmental Monitoring Program plays a key role in the effort to investigate the effects that years of operation have had on the local environment. Environmental monitoring primarily examines the air and water pathways; other program components address contamination risks associated with cleanup procedures. A summary of air and liquid pathway results is presented below.

\section{Air Pathway}

Monitoring the air pathway incorporates results not only from the air monitoring stations but also from soil, grass, produce, and milk sampling. (Radon monitoring is discussed separately below.) Overall, the air monitoring data from 1995 were consistent with data from 1994, and with the exception of short-term opacity excursions, all Boiler Plant emissions were well below permit limits.

Data collected from fence line air monitoring stations showed that average concentrations of uranium were all less than $1 \%$ of the DOE standard. Airborne emissions for 1995 were estimated to be $1.67 \mathrm{~kg}$ (3.67 lbs). Airborne uranium emissions steadily dropped after processing operations were discontinued in 1989 , and they have remained relatively constant since 1991 .

Uranium concentrations in offsite soil samples ranged from $0.0043 \mathrm{pCi} / \mathrm{g}$ to 0.13 $\mathrm{pCi} / \mathrm{g}(0.0063 \mathrm{ppm}$ to $0.19 \mathrm{ppm})$ and are within the range of naturally occurring uranium concentrations in Ohio soil. Previous environmental monitoring has shown some onsite and nearby offsite soils to have elevated concentrations of uranium due to the deposition of airborne uranium released during the production period.

The 1995 results from grass sampling indicated that uranium concentrations are within the range of historical concentrations and suggest that 1995 emissions have not significantly affected uranium concentrations in grass.

Home-grown sweet corn and tomatoes are two of the major crops sold from roadside stands within $5 \mathrm{~km}$ ( 3 miles) of the site. Local residents also grow and sell beets, potatoes, apples, lettuce, pumpkins, cucumbers, and peppers. Uranium concentrations in produce in 1995 were consistent with previous years' data. Laboratory analyses did not detect any significant differences in uranium concentrations between produce grown near the site ( 0 to $5 \mathrm{~km}$ or 0 to 3 miles) and produce grown at distant locations ( 11 to $42 \mathrm{~km}$ or 7 to 26 miles).

Uranium concentrations from the local dairy's milk were comparable to those from a background dairy in Indiana. The data demonstrated that milk from the local dairy is not affected by site emissions. 
Measurements of direct radiation indicate that levels increase with proximity to the K-65 silos. However, these levels are $80 \%$ lower than radiation levels measured in 1991 prior to the addition of the bentonite layer within the K-65 silos. These measurements are consistent with the fact that the silos contain radium and its decay products which contribute to the direct radiation in the vicinity.

\section{Radon Monitoring}

Radon is transported through the air pathway and is, therefore, discussed here. However, radon monitoring results are reported separately in this Site Environmental Report from the air pathway in order to improve the presentation of information and regulations that are unique to radon.

In 1995, the average fence line radon concentration was $0.7 \pm 0.4 \mathrm{pCi} / \mathrm{L}$. This concentration is less than the 1994 average concentration of $0.8 \mathrm{pCi} / \mathrm{L}$, but it is well below the guideline of $3.0 \mathrm{pCi} / \mathrm{L}$. For comparison, the average background concentration measured in 1995 was $1.3 \mathrm{pCi} / \mathrm{L}$.

\section{Liquid Pathway: Effluent and Surface Water}

\section{SEE ADDENOUM}

The effluent and surface water component of the liquid pathway is monitored to determine any impacts from the Fernald site on the Great Miami River and Paddys Run. The Environmental Monitoring Program examines the effluent and surface water results, along with sediment and fish results because they are also part of the liquid pathway.

Approximately $179 \mathrm{~kg}$ (394 lbs) of uranium were discharged to the Great Miami River during 1995. Of that total, $22.6 \mathrm{~kg}$ (49.7 lbs) were from Manhole-175 and $138.2 \mathrm{~kg}$ (304 lbs) were from South Plume/Stormwater Retention Basin pumping during the first 10 months of the year. The remaining $17.9 \mathrm{~kg}(39.4 \mathrm{lbs})$ were a combination of all effluents as measured at the Parshall Flume during November and December 1995.

The liquid effluent discharged to the Great Miami River resulted in a slightly higher measurement of uranium at the downriver sampling location than the upriver location. However, the downriver concentration was consistent with 1994 sampling results. Paddys Run continued to show effects of stormwater runoff from the site. Although the average uranium concentration at the nearest offsite sampling location was higher than in 1994, it was only $1.05 \%$ of the DOE guideline for drinking water. (That guideline is used for comparison purposes only since there is no established guideline for uranium in surface water.)

Radionuclide concentrations in the Great Miami River and Paddys Run sediments for 1995 were consistent with previous years' data and did not indicate a build-up of radioactive pollutants in the sediment. 
In 1995, fish from three locations along the Great Miami River were sampled for uranium. Results indicated that uranium concentrations were no greater in fish caught downstream of the site effluent line than in those caught upstream.

The National Pollutant Discharge Elimination System (NPDES) permit specifies sampling locations, sampling and reporting schedules, discharge limits, water quality standards, and other restrictions on the Fernald site effluents discharged to the Great Miami River and Paddys Run. Out of the 2,367 NPDES samples taken at internal and external monitoring locations in 1995, there were 37 violations of NPDES limits at Manhole-175, the final NPDES monitoring point before effluents are discharged to the river. The violations concerned the dissolved oxygen and suspended solid concentrations of effluent released to the Great Miami River.

\section{Liquid Pathway: Groundwater}

The site carefully monitors the groundwater beneath and in the vicinity of the site to identify and track the movement of pollutants which may be present in the Great Miami Aquifer. In 1995 the Fernald site routinely sampled 33 private wells for total uranium. Three of these wells, each of which is in an area of known ground water contamination, had an average uranium concentration above the proposed USEPA standard of $13.5 \mathrm{pCi} / \mathrm{L}$ ( $20 \mathrm{ppb}$ ). Of these 33 wells, 32 wells were also sampled for several metals. One well showed a concentration of lead at or above the Primary Drinking Water Standard as listed for the control of lead. Additionally, as is common for an area with high natural concentrations of iron and manganese, such as the area surrounding the Fernald site, several private wells showed concentrations of these two metals above the USEPA Secondary Drinking Water Standards.

Aside from the private well sampling program, the Fernald site conducts comprehensive groundwater sampling of several site-owned wells. In 1995, the site sampled 157 on- and offsite wells for uranium, and 50 wells showed detections above the proposed USEPA guideline of $13.5 \mathrm{pCi} / \mathrm{L}(20 \mathrm{ppb})$. All of the offsite locations were in the South Groundwater Contamination Plume area. This comprehensive program also sampled those wells for 11 metals and 31 Volatile Organic Compounds that have Primary Drinking Water Standards. Of these 42 constituents, 11 were detected above their primary standards in more than one well. Three other constituents showed single detections above the secondary standard. 


\section{Estimated Radiation Dose for 1995}

Scientists calculate potential radiation doses to nearby residents by utilizing mathematical models which include offsite radionuclide concentrations determined through environmental monitoring and sampling.

In 1995, the hypothetical maximally-exposed individual living nearest the Fernald site, exclusively consuming local foodstuffs and fish, along with drinking water from a well in the Fernald area, could have received a maximum committed effective dose of approximately $0.1 \mathrm{mrem}$. (This dose is exclusive of the dose received from radon.) This dose can be compared to the limit of 100 mrem for all pathways (also exclusive of radon) that was established by the International Commission on Radiological Protection and adopted by DOE.

\section{Dose Attributable to Radon}

Just as radon monitoring results are discussed separately from the air pathway monitoring results, the dose attributable to radon is discussed separately from the rest of the estimated radiation dose for 1995.

As discussed above, the radon concentration measured at the site fence line in 1995 was $0.7 \pm 0.4 \mathrm{pCi} / \mathrm{L}$. The effective dose calculated from this concentration was estimated to be $504 \mathrm{mrem}$, and it includes the annual dose received from average background levels of radon (approximately 200 mrem per year). 



\section{INTRODUCTION TO THE SITE}

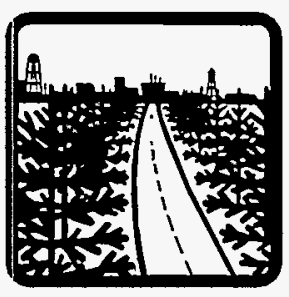




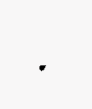




\section{Introduction to the Site}

The Fernald Environmental Management Project (FEMP), which is owned by the Department of Energy (DOE) and operated by the Fernald Environmental Restoration Management Corporation (FERMCO), focuses entirely on environmental restoration and waste management activities. Because the Fernald site was formerly a uranium metals processing facility, scientists have closely investigated the site and surrounding areas to determine the nature and extent of radioactive contamination. Remedial techniques are then developed accordingly.

This Site Environmental Report (SER) documents the results of the Environmental Monitoring Program for calendar year 1995. In accordance with DOE Order 5400.1, General Environmental Protection Program, the information in the 1995 SER is current from January 1, 1995, through December 31,1995 . In order to put the information presented in this report into perspective, Chapter One contains the following introductory sections:

- The Fernald Site Mission: Environmental Compliance and Restoration, a historical overview of the site's former operations and a description of its current cleanup mission and site restoration activities;

- Environmental Program Information, a description of site activities aimed at monitoring environmental quality;

- Local Geography, an introduction to the physical, ecological, and human characteristics of the area;

- Exposure Pathways to Humans, an examination of the physical and biological surroundings as possible routes for contaminants to reach local communities; and

- Environmental Standards and Guidelines, a description of the various standards with which the Fernald site must comply to protect the local environment. 


\section{The Fernald Site Mission: Environmental Compliance and Restoration}

Since 1989, the mission at the Fernald site has been one of environmental compliance and restoration. However, when the site was established in the early 1950s, its primary mission was to process uranium metal.

Shortly after the end of World War II, the United States recognized a need for new facilities to produce uranium metal in support of defense activities. Existing facilities, developed for the war effort, were neither economical to operate nor capable of meeting increasing demands. The Atomic Energy Commission (AEC) required an increase in the quality and quantity of uranium metal as well as improvements in the control and safety of production operations.

After evaluating several sites, the government selected a 425-hectare (1,050-acre) area, about $27 \mathrm{~km}$ ( 17 miles) northwest of downtown Cincinnati, Ohio, as the site for a new production facility (see Figure 1). This facility was sited just north of Fernald, Ohio, a small farming community. The government broke ground on May 16, 1951, and produced the first uranium derby at the site's Pilot Plant on October 11, 1951. The major portion of construction was complete by 1954 .

In general, the relative importance and corresponding funding of the former production and environmental activities reflect the course of U.S. Defense history from the end of World War II until today. Uranium-metal production reached a peak during the height of the Cold War in the 1950s and 1960s. During the late 1970s, funding for production and supporting organizations, including environmental monitoring, was significantly reduced. Production accelerated again in the early 1980s when the United States increased defense spending. By the late 1980s, however, an increasing demand for environmental accountability, combined with a decreasing demand for uranium metal at other DOE facilities, led DOE to change the site's mission from uranium production to environmental restoration.

Production was suspended in July 1989. In October 1990, DOE transferred management responsibility for the site from its Defense Programs organization to the Office of Environmental Restoration and Waste Management. In February 1991, DOE announced its intention to formally end the production mission and submitted a closure plan to Congress, which became effective in June 1991.

\section{An Overview of Former Production Operations}

Although production at the Fernald site ended in 1989, a brief overview of the former production operations will provide the reader with a perspective on the ongoing Environmental Monitoring Program and other environmental investigations. 
Figure 1: Fernald Site and Vicinity

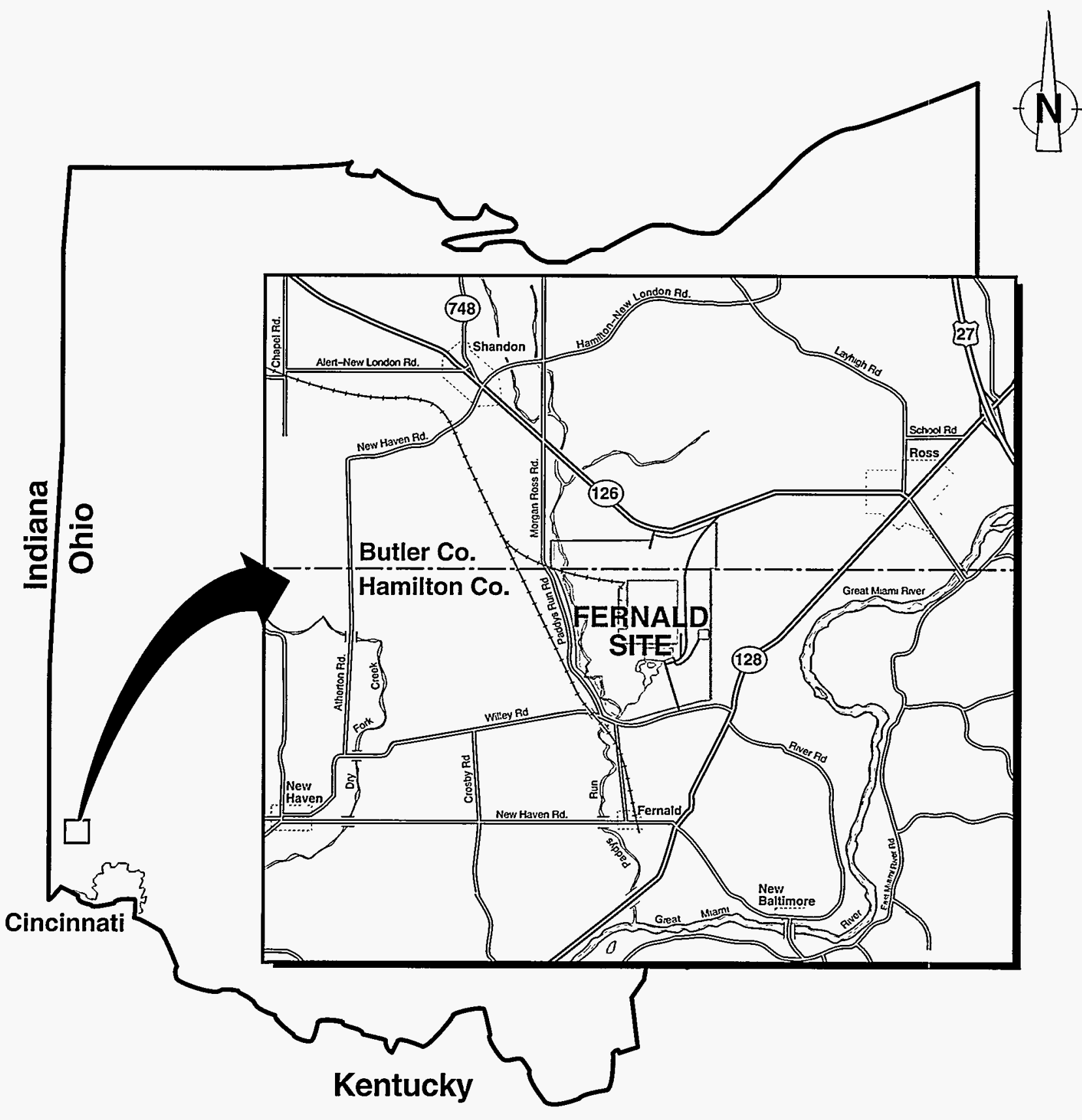

The Fernald Site covers about 425 hectares (1,050 acres). 
The major steps in the production process are highlighted in Figure 2. A variety of materials were used in the process, including many received from other DOE sites. Even materials such as floor sweepings, dust collector residues, and production residues were recycled in order to recover as much uranium as possible.

\section{DEPLETED AND ENRICHED URANIUM}

Much of the uranium processed at Fernald was depleted in the uranium-235 isotope; that is, it contained less than $0.71 \%$ uranium- 235 , the concentration found in naturaliy occurring uranium. (Isotopes are discussed in Chapter Two, Fundamentals of Radiation and Health Hazards.) During the years of production at Fernald, the uranium processed contained various concentrations of uranium-235, ranging from depleted to slightlyenriched up to $2 \%$.
The first production steps involved chemical processing that ended with an intermediate product commonly called green salt (uranium tetrafluoride, $\left.\mathrm{UF}_{4}\right)$. The green salt was then blended with magnesium-metal granules, placed in a closed reduction pot, and heated in furnaces in Plant 5 (see Figure 3, building ID No. 65). The product of this operation was a mass of uranium metal called a derby.

Some derbies were sent directly to other DOE sites, while the site remelted the remainder, along with uranium scrap-metal recovered from earlier production, and poured them into graphite molds to form ingots. Ingots varied in weight, size, and shape according to how they were to be used at other DOE sites. Machining of these ingots occurred in Plants 6 and 9, after which the billets (machined ingots) were shipped to other DOE sites, principally the Savannah River Site in Aiken, South Carolina, and the Hanford Site in Richland, Washington.

\section{Handling and Storing Radioactive and Hazardous IMaterials}

Although the site no longer produces uranium metals, it continues to store materials once used here and at other DOE sites. Some of the radioactive and hazardous materials that were handled or stored onsite during 1995 include:

\section{Radioactive}

- Dilute hydrogen fluoride,

- Magnesium fluoride $\left(\mathrm{MgF}_{2}\right)$ contaminated with uranium,

- Pitchblende ore residues containing radium stored in the $\mathrm{K}-65$ silos,

- Radioactive materials in the waste pits,

- Scrap metal contaminated with uranium compounds,

- Thorium and thorium compounds stored within the production area,

- Uranium compounds, and

- Uranium metal. 


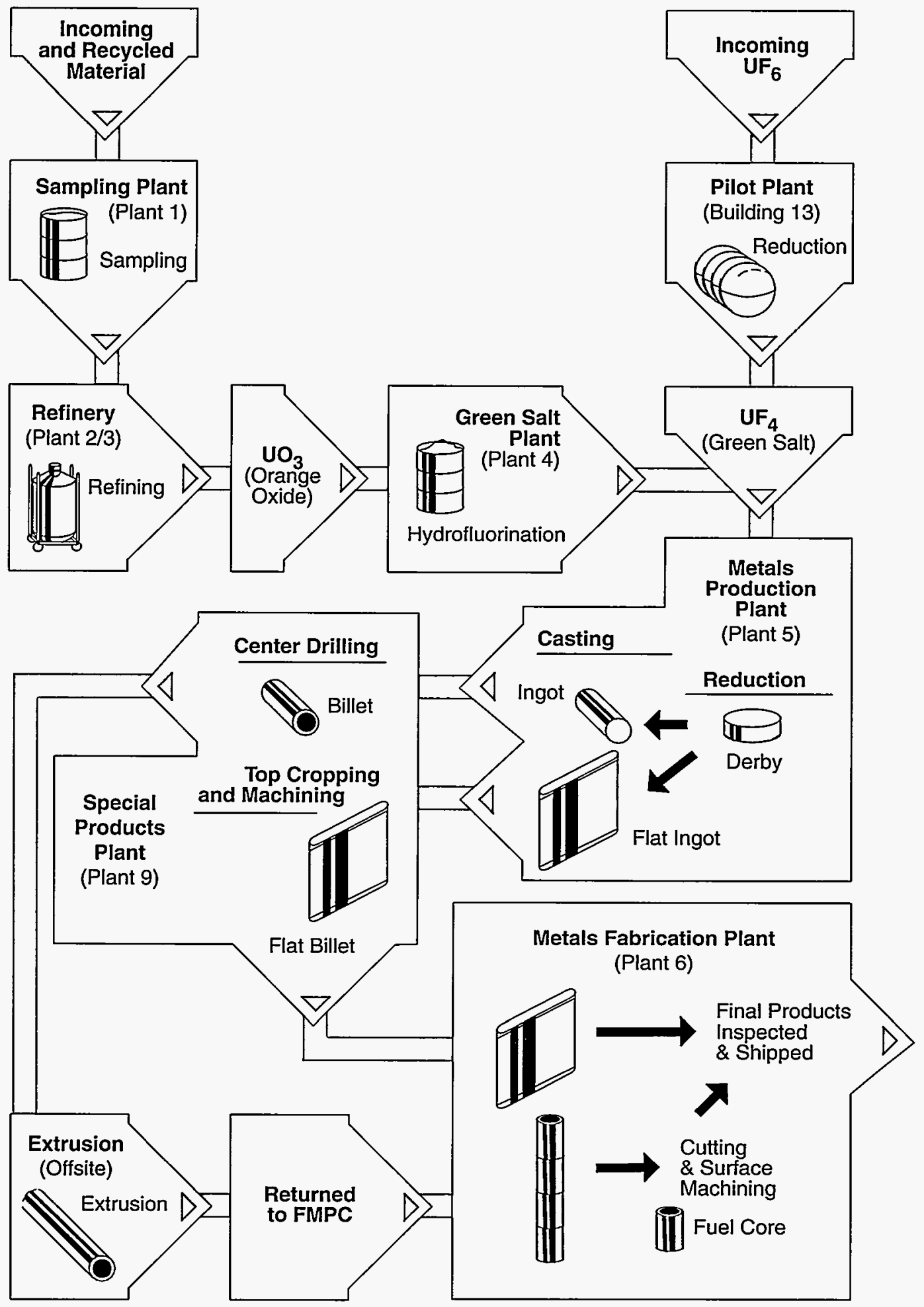


Figure 3: Fernald Site Perspective

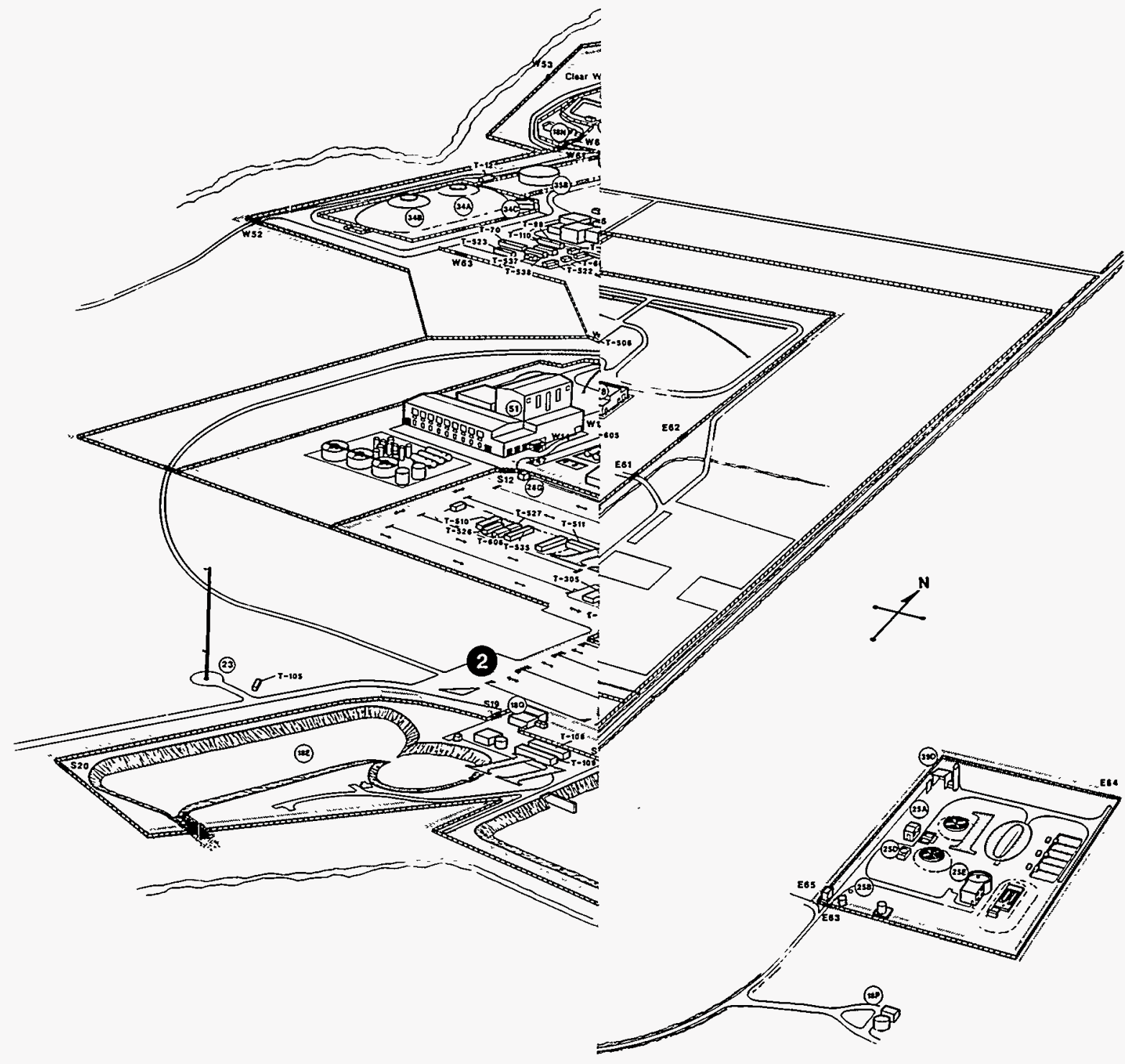


Figure 3: Fernald Site Perspective

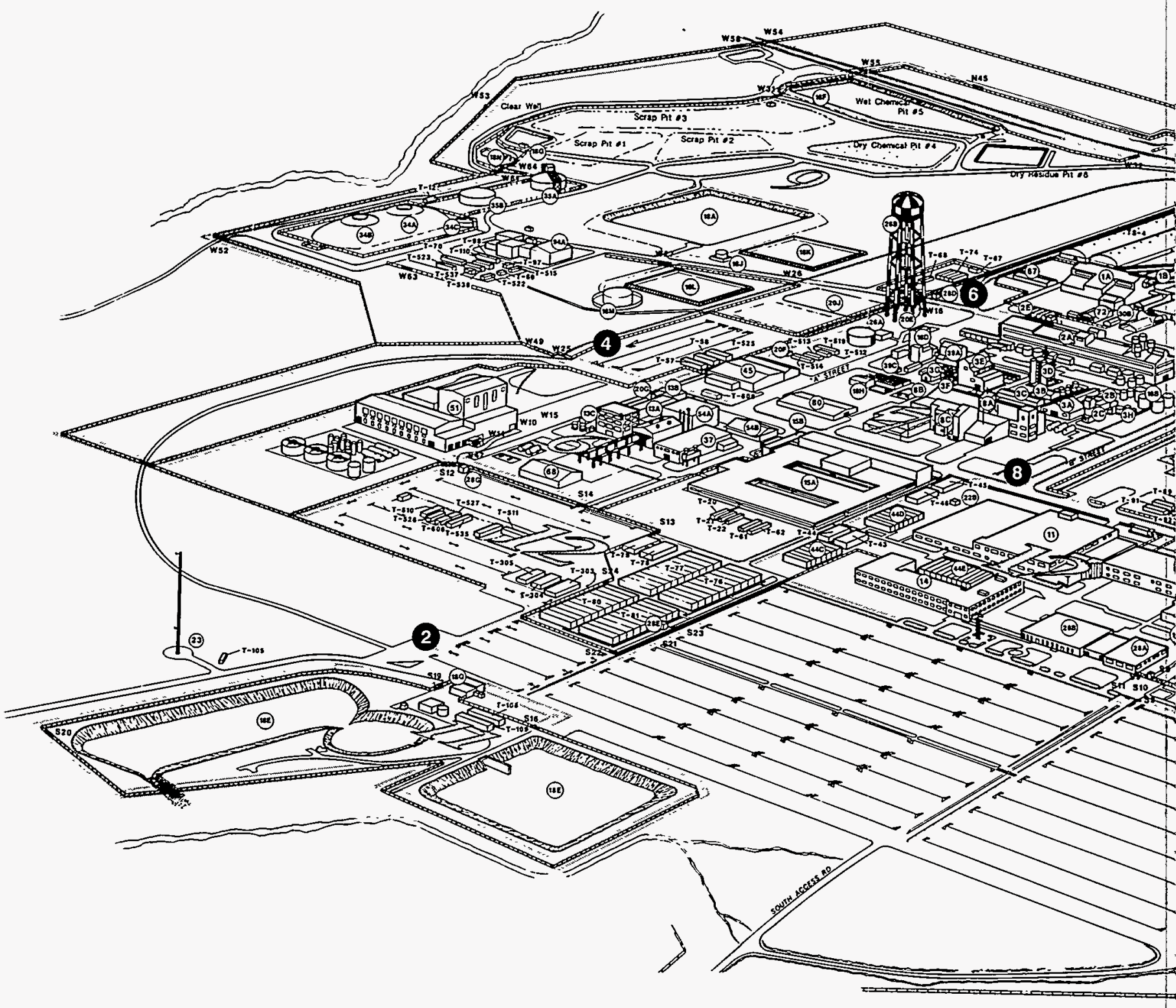




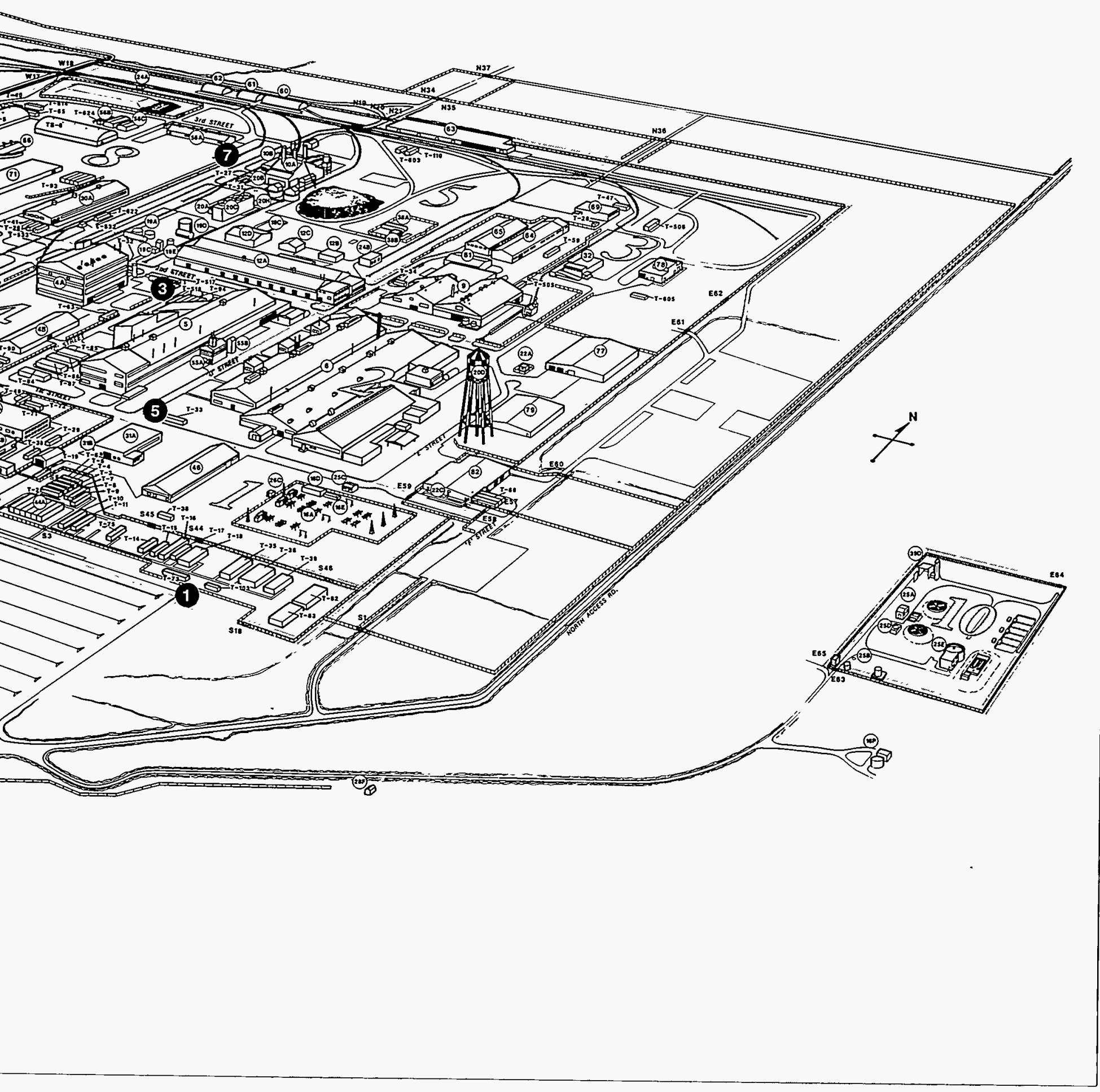




\section{Building Identification}

\begin{tabular}{|c|c|c|c|c|c|}
\hline $\begin{array}{l}\text { Building } \\
\text { ID No. }\end{array}$ & $\begin{array}{l}\text { Grid } \\
\text { Coordinates }\end{array}$ & Title & $\begin{array}{l}\text { Building } \\
\text { ID No. }\end{array}$ & $\begin{array}{l}\text { Grid } \\
\text { Coordinates }\end{array}$ & Title \\
\hline 00 & $\star \star$ & General & $22 c$ & A-5 & Truck Scale \\
\hline la & $C-3$ & Preparation Plant & 23 & $\star$ & Meteorological Tower \\
\hline ib & $C-3$ & Plant I Storage Building & $24 a$ & $D-3$ & Railroad Scale House \\
\hline $2 a$ & B-3 & Ore Refinery Plant & $24 b$ & $C-4$ & Railroad Engine Building \\
\hline $2 \mathrm{~b}$ & B-3 & Lime Handling Building & $25 a$ & * & Chlorination Building \\
\hline $2 c$ & B-3 & Bulk Lime Handling Building & $25 b$ & * & Manhole-175 \\
\hline $2 d$ & B-3 & Metal Dissolver Building & $25 c$ & A-5 & Sewage Lift Station Building \\
\hline $2 \mathrm{e}$ & $C-3$ & NFS Storage and Pump House & $25 d$ & $*$ & U.V. Disinfection Building \\
\hline $3 a$ & $B-3$ & Maintenance Building & $25 \mathrm{e}$ & * & Digester Control Building \\
\hline $3 \mathrm{~b}$ & B-3 & Ozone Building & $26 a$ & $\mathrm{~B}-3$ & Pump House - H.P. Fire Protection \\
\hline $3 c$ & $B-3$ & Control House & $26 b$ & B-3 & Elevated Water Storage Tank \\
\hline $3 d$ & $B-3$ & NAR Towers & $28 a$ & A-4 & Security Building \\
\hline $3 e$ & B-3 & Hot Raffinate Building & $28 \mathrm{~b}$ & $A-4$ & Human Resources Building \\
\hline $3 f$ & $\mathrm{~B}-3$ & Digestion Fume Recovery & $30 a$ & $C-3$ & Chemical Warehouse \\
\hline $3 g$ & B-3 & Refrigeration Building & $30 \mathrm{~b}$ & $\mathrm{C}-3$ & Drum Storage Warehouse \\
\hline $3 h$ & B-3 & Refinery Sump & 31 & A-5 & Engine House - Garage \\
\hline $4 a$ & B-4 & Green Śalt Plant & 32 & D-5 & Magnesium Storage \\
\hline $4 b$ & B-4 & Plant 4 Warehouse & $34 a$ & $B-1$ & K-65 Storage Tank - North \\
\hline $4 c$ & B-4 & Plant 4 Maintenance Building & 340 & B-1 & K-65 Storage Tank - South \\
\hline 5 & $B-4$ & Metals Production Plant & $35 a$ & $C-1$ & Metal Oxide Storage Tank - North \\
\hline 6 & B-5 & Metals Fabrication Plant & $35 b$ & B-1 & Metal Oxide Storage Tank - South \\
\hline $8 a$ & B-3 & Recovery Plant & 37 & A-3 & Pilot Plant Annex \\
\hline $8 \mathrm{~b}$ & B-3 & Maintenance Building & 38 & $D-4$ & Propane Storage \\
\hline $8 c$ & B-3 & Rotary Kiln/Drum Reconditioning & $39 a$ & B-3 & Incinerator Building \\
\hline 9 & $C-5$ & Special Products Plant & $39 \mathrm{~b}$ & $\mathrm{~B}-3$ & Shelter Storage Building \\
\hline $10 a$ & D-4 & Boiler Plant & $39 c$ & B-3 & Incinerator Building Sprinkler \\
\hline $10 \mathrm{~b}$ & D-4 & Boiler Plant Maintenance Building & & & Riser House \\
\hline 11 & A-4 & Service Building & $44 a$ & $A-5$ & Trailer Complex — 6-Plex (East) \\
\hline $12 a$ & $C-4$ & Maintenance Building (Main) & $44 c$ & A-3 & Trailer Complex - 7-Plex (South) \\
\hline $12 b$ & $C-4$ & Cylinder Storage Building & $44 d$ & A-3 & Trailer Complex - 7-Plex (North) \\
\hline $12 c$ & $\mathrm{C}-4$ & Lumber Storage Building & $44 \mathrm{e}$ & $A-4$ & Trailer Complex - 10-Plex \\
\hline $13 a$ & A-3 & Pilot Plant Wet Side & 45 & $\mathrm{~B}-3$ & Rust Engineering Building \\
\hline $13 b$ & A-3 & Pilot Plant Maintenance Building & 46 & $A-5$ & Heavy Equipment Garage \\
\hline $13 c$ & A-3 & Sump Pump House & 51 & $A-2$ & $\mathrm{UF}_{6}$ to $\mathrm{UF}_{4}$ Reduction Facility 11 \\
\hline 14 & $A-4$ & Administration Building & $53 a$ & $A-4$ & Occupational Safety \& Health \\
\hline 15 & A-3 & Laboratories & $53 \mathrm{~b}$ & $A-4$ & In-Vivo Building \\
\hline $16 a$ & A-5 & Main Electrical Station & $54 a$ & A-3 & UF $_{6}$ to UF $_{4}$ Reduction Facility I \\
\hline $16 \mathrm{~b}$ & $A-4$ & Electrical Substation & $54 \mathrm{~b}$ & $A-3$ & Pilot Plant Warehouse \\
\hline $18 a$ & $C-2$ & Biodenitrification Surge Lagoon & $55 a$ & $8-4$ & Slag Recycling Plant \\
\hline $18 \mathrm{~b}$ & $\mathrm{~B}-\overline{3}$ & General Sump & $55 b$ & $B-4$ & Slag Recycling Pit/Elevator \\
\hline $18 \mathrm{c}$ & $C-4$ & Coal Pile Runoff Basin & 56 & D-3 & CP Storage Warehouse \\
\hline $18 d$ & B-3 & Biodenitrification Towers & 60 & D-3 & Quonset Hut \#1 \\
\hline $18 \mathrm{e}$ & $\star$ & Stormwater Retention Basin & 61 & D-3 & Quonset Hut \#2 \\
\hline $18 f$ & D-1 & Pit 5 Sluice Gate & 62 & D-3 & Quonset Hut \#3 \\
\hline $18 g$ & $C-1$ & Clearwell Pump House & 63 & D-4 & KC-2 Warehouse \\
\hline $18 \mathrm{~h}$ & B-3 & BDN Effluent Treatment Facility & 64 & D-5 & Thorium Warehouse \\
\hline $18 \mathrm{k}$ & $\mathrm{B}-2$ & Methanol Tank & 65 & D-5 & (Old) Plant 5 Warehouse \\
\hline 181 & $C-2$ & Low Nitrate Tank & 66 & $\mathrm{C}-3$ & Drum Reconditioning Building \\
\hline $18 \mathrm{~m}$ & B-2 & High Nitrate Tank & 67 & $\mathrm{C}-3$ & Plant I Thorium Warehouse \\
\hline $18 n$ & $\bar{B}-2$ & Hiah Nitrate Storage Tank & 68 & $A-3$ & Pilot Plant Warehouse \\
\hline $19 a$ & $\bar{C}-4$ & Main Metal Tank Farm & 69 & D-5 & Decontamination Building \\
\hline $19 \mathrm{~b}$ & $A-3$ & Pilot Plant Ammonia Tank Farm & 71 & C-3 & General In-Process \\
\hline $20 a$ & $C-4$ & Pump Station and Power Center & & & Storage Warehouse \\
\hline $20 \mathrm{~b}$ & D-4 & Water Plant & 72 & $\mathrm{C}-3$ & Drum Storage Building \\
\hline $20 c$ & $C-4$ & Cooling Towers & 73 & & Fire Brigade Training \\
\hline 20d & B-5 & Elevated Storage Tank & & & Center Building \\
\hline & & (Potable $\mathrm{H}_{2} \mathrm{O}$ ) & 77 & C-5 & Finished Products Warehouse \\
\hline $20 \mathrm{e}$ & B-3 & Well House \# 1 & 78 & * & New D\&D Facility \\
\hline $20 f$ & $\mathrm{~B}-3$ & Well House \#2 & 79 & $B-5$ & Plant 6 Warehouse \\
\hline $20 a$ & A-3 & Well House \#3 & 80 & B-3 & Plant 8 Warehouse \\
\hline $20 \mathrm{~h}$ & D-4 & Process Water Storage Tank & 81 & $C-5$ & Plant 9 Warehouse \\
\hline $20 \mathrm{j}$ & $\mathrm{B}-2$ & Lime Slurry Pits & 82 & B-5 & Receiving \& Incoming \\
\hline $22 a$ & B-5 & Gas Meter Building & & & Materials Inspection Area \\
\hline $22 \mathrm{~b}$ & $A-3$ & Storm Sewer Lift Station & \multicolumn{3}{|c|}{$\begin{array}{l}\text { - Outside of Perimeter Security Fence } \\
\star \star \text { NOTE: Any Unidentified Area is Referred to as } 00 \text { General }\end{array}$} \\
\hline
\end{tabular}




\section{Hazardous}

- Heavy metals,

- Hydrochloric acid,

- Laboratory chemicals,

- Methanol,

- Nitric acid,

- Process waste,

- Sodium hydroxide, and

- Sulfuric acid.

The site has repackaged some materials into new drums and removed materials no longer needed since production ended. For example, thorium previously stored in a deteriorating above-ground silo, in bins, and in drums on an outdoor pad has been repackaged in new drums and stored in a warehouse. The Fernald site continues to reduce its inventory of radioactive and hazardous materials once used in production by disposing of them at designated waste disposal facilities.

\section{Environmental Restoration Activities}

In fulfillment of its current mission, the site continues to strive for compliance with all environmental regulations while working toward site restoration. During 1995 , this was evident in many activities that will contribute to the final remediation of the Fernald site. Some of the more prominent activities during 1995 are described next.

\section{UNH Neutralization Project}

During 1995, approximately 200,000 gallons of Uranyl Nitrate Hexahydrate (UNH) was safely neutralized and prepared for disposal. Essentially uranium dissolved in nitric acid, UNH was an intermediate compound in the uranium recovery process during the production years at Fernald. Due to its high acid content, UNH became a Resource Conservation and Recovery Act (RCRA) issue when DOE declared the material to be waste.

Formerly stored in tanks in and around the former Refinery Plant (Plant 2/3), the UNH solution was diluted with water, neutralized with magnesium hydroxide, and filtered. Solid waste resulting from the process was placed in 55-gallon drums and shipped to the Nevada Test Site (NTS) for disposal. Uranium was removed from the liquid filtrate through the Advanced Waste Water Treatment facility. The liquid filtrate was tested for heavy metals and acid content to confirm its acceptability for discharge to the Great Miami River under Fernald's current National Pollutant Discharge Elimination System permit, regulated by Ohio Environmental Protection Agency (OEPA).

The first phase of the UNH project began March 24, 1995, with in-situ (in-place) neutralization of about $10 \%$ of the UNH material. The second phase began June 
15 , when dedicated pipelines, pumps and tanks were placed in operation. The project was safely completed on September 25, 1995.

\section{Vitrification Pilot Plant}

In 1995, construction continued on the vitrification Pilot Plant to convert residues from silos 1,2 and 3 into a glass form that is stable, durable, and safe for permanent disposal. Vitrification (glassification) will reduce the mobility of hazardous substances and significantly reduce the volume of materials requiring disposal. Radium-bearing residues from the two K-65 silos will be heated in a high-temperature furnace under controlled conditions to form a glass-like substance. Radon gas, a principal product of radium radioactive decay, will be trapped in the vitrified material to eliminate further emissions

\section{Future Land Use at the Fernald Site}

The Fernald Citizens Task Force (CTF) focused its future use recommendations on creating a broad understanding of how the Fernald site could best be used following remediation, rather than identifying specific land use plans for the property. The CTF believes specific uses of the property should be determined (within the general guidelines established by the CTFI closer to the time of reuse by the people most impacted by that use. Following those guidelines, it was recommended that residential and agricultural uses be avoided on the property. However, productive use of the land was considered important as well. Accordingly, remediation levels recommended by the CTF allow for all other uses, including the potential for recreation and industry. The CTF also recommended that a substantial buffer area separate the planned on-site disposal cell and any other uses of the property. of radon to the environment. The vitrified residues will be containerized, transported, and disposed at NTS.

The Pilot Plant is scheduled to do test operations using non-radioactive surrogate material beginning in mid-1996. Current schedules call for actual silo wastes to be fed into the furnace beginning in 1997.

\section{Thorium Nitrate Stabilization}

\begin{abstract}
Almost 6,000 gallons of thorium nitrate, a contaminated acid waste stream, were treated and solidified safely in 1995 in full compliance with environmental regulations. Disposition of the acid eliminates a potential threat to workers and the environment and clears the path for decontamination and dismantlement activities to continue without disruption.
\end{abstract}

The final rinse of the thorium nitrate tank was completed November 9, 1995, less than two months after Chem-Nuclear, FERMCO's subcontractor, began processing the material and six months after FERMCO and Chem-Nuclear began designing the treatment system. During the project, 369 drums of solidified thorium cement were generated.

\section{Plant 4 Decontamination \& Decomissioning (D\&D)}

In support of the Fernald site's accelerated remediation plan, Plant 4 D\&D activities began in March 1995. Plant 4, a four-story structure, was built in 1953 to house the chemical processes (hydrofluorination) which produced green salt (described on page 4). The building is being emptied, cleaned and stripped down to its structural steel framework. Final demolition is scheduled to be completed in fiscal year 1996 (October 1, 1995 - September 31, 1996). 


\section{Environmental Program Information}

The Fernald site conducts environmental program activities to monitor environmental quality in the area surrounding the site. Some of these activities include the Environmental Monitoring Program, the Meteorology Program, the Waste Minimization Program, and Natural Resource Management, which are described below.

\section{Environmental Monitoring Program}

Federal and state waste management requirements applied during the site operation period are still in effect because of the onsite waste storage. Earlier regulations were often less stringent, and the consequences of past operations are still evident. Today, Fernald site personnel continue to investigate these effects on the environment. The Environmental Monitoring Program plays a key role in this effort. Like any complex program or investigation, the Environmental Monitoring Program was developed after careful consideration of many components. For example, former site production processes which involved both radioactive and nonradioactive materials resulted in air and liquid releases to the environment. The monitoring program is largely based upon the flow of these materials through the air and liquid pathways. Additional program components address contamination risks associated with cleanup procedures.

Environmental monitoring activities seek to determine the amount of radioactive and nonradioactive materials that leave the site and enter the surrounding environment. In short, this year-round Environmental Monitoring Program has several responsibilities:

- Ensure the site has procedures in place to detect any unexpected release of materials so that corrective actions can be taken,

- Closely monitor releases to ensure air emission and liquid effluent standards and guidelines are not exceeded,

- Evaluate the impact of site activities (past and present) on the environment,

- Estimate the radiation dose that area residents may be exposed to as a result of former production operations and current cleanup activities at the site, and

- Measure progress in correcting problems from past operations and in implementing improved environmental management practices.

\section{Meteorology Program}

The Fernald site's meteorological monitoring system was installed in August 1986. The meteorological tower is 60 meters ( 197 feet) tall, with monitoring equipment at both the 10-meter (33-foot) and 60-meter (197-foot) heights. The tower instruments measure wind speed and direction, ambient air temperature, relative humidity, barometric pressure, solar radiation, and precipitation (see Table 1 on page A-2 for a partial summary). 
The meteorological instruments are inspected and re-calibrated regularly to ensure they are functioning properly. The system is down during routine maintenance periods but not for a length of time that significantly affects the database. While the system is down, it is possible to obtain a limited amount of meteorological data from the Greater Cincinnati-Northern Kentucky International Airport, located about $27 \mathrm{~km}$ (17 miles) south of the site.

Meteorological data gathered at the site are primarily used to evaluate climatic conditions at the site. The Environmental Monitoring Program uses atmospheric models to determine how airborne effluents are mixed and dispersed. These models are then used to assess the impact of operations on the surrounding environment, in accordance with DOE requirements.

Airborne pollutants are subject to existing weather conditions. Wind speed and direction, rainfall, and atmospheric stability play a role in predicting how pollutants are distributed in the environment. Weather data, particularly wind speed and direction, provide guidance in collecting environmental samples and determining sites for monitoring stations.

Figures 4 and 5 (on the next page) are annual wind roses, which illustrate the average wind speed and general direction measured at the 10-meter (33-foot) and 60meter (197-foot) levels in 1995. The prevailing winds were from the west, west-southwest and southwest (10\% each or $30 \%$ total) at the 10 -meter level. The prevailing winds at the 60 -meter level were from the south-southwest (10\%) and from the west-southwest (11\%) during 1995.

The prevailing west and southwest winds occur as the result of the general westto-east flow of air at the midlatitudes of the earth. The winds blowing from the northeast were usually a result of drainage winds which frequently occur overnight along the Great Miami River basin. Overnight, during periods of cooling, the earth cools more rapidly at higher elevations. The cooler, more dense air will then flow down to areas of lower elevation. Hence, air can drain down a valley creating a light downhill breeze. Consequently, as the proper conditions occur, cooler, more dense air flows from higher elevations farther up the Great Miami River basin toward the lower elevations to the south-southwest.

In 1995, the precipitation measured at the Fernald site was $114.8 \mathrm{~cm}$ (45.21 inches), which is higher than the average annual precipitation of $104 \mathrm{~cm}$ (41 inches) for 1965 through 1994. Figure 6 shows 1995's total precipitation for the area in relation to the annual precipitation amounts recorded since 1985. (Precipitation totals for 1985 through 1992 were taken from the measurements made at the Greater Cincinnati/Northern Kentucky International Airport because of a computer software problem at the site meteorological tower. This problem was corrected, and the 1993 through 1995 totals were taken from measurements made at the Fernald site.) 


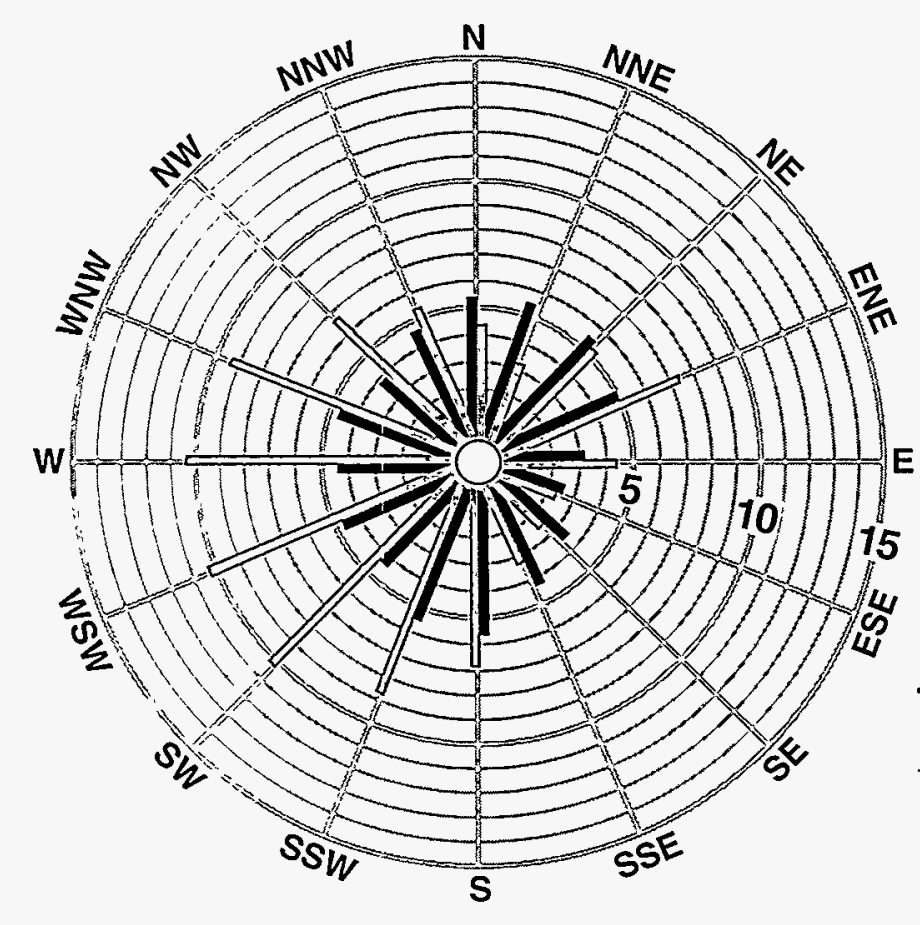

3309

\section{LEGEND}

Average wind speed from this direction.

Percentage of time that the wind blew from this direction.

Figure 5: 1995 W/ind Rose Data, 60-Meter Height

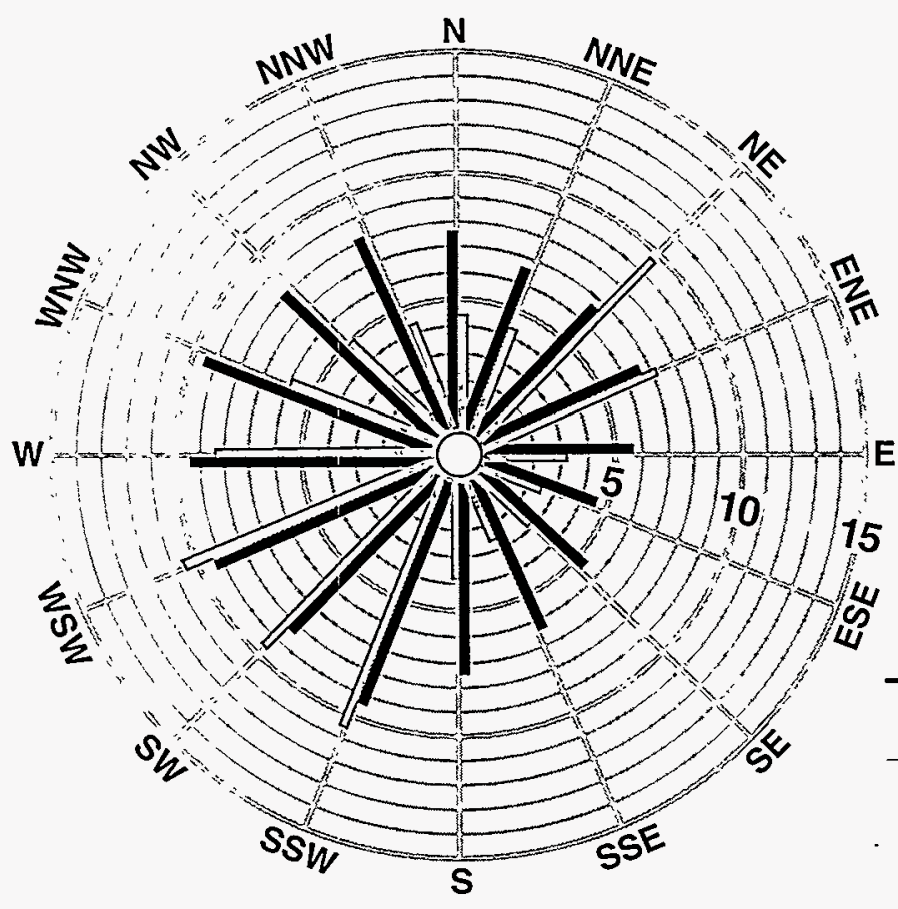

3309

\section{LEGEND}

Average wind speed from this direction. Percentage of time that the wind blew from this direction. 


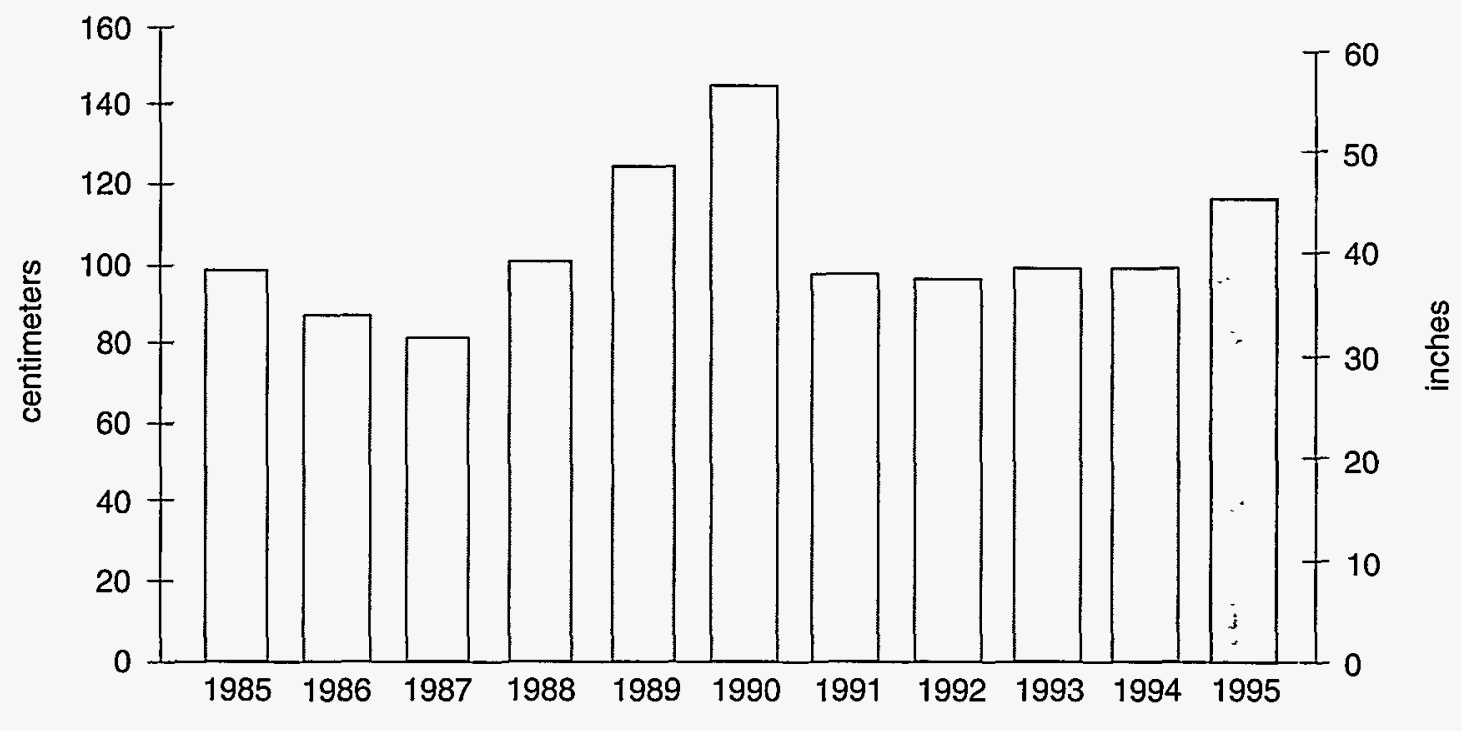

Precipitation totals prior to 1993 are from the Greater Cincinnati - Northern Kentucky International Airport. Totals from 1993 through 1995 are from the site.

\section{Waste Minimization Program}

Environmental remediation activities generate significant amounts of waste requiring management. At first glance, waste minimization does not seem to apply to remediation work becausethe goal of waste minimization is to reduce the total amount of waste generated. However, the real challenge of the Waste Minimization Program is to reduce the amount of secondary waste generated during remediation and to recycle or reuse primary waste, as appropriate.

The Waste Minimization Program at the Fernald site has been recognized by DOE as a benchmark program for applying waste minimization and pollution prevention principles at a remediation site. Fernald has developed an exceptional model for project planning and project integration to ensure that the most cost-effective decisions are made and that communications between all organizations are ongoing and effective.

The Waste Minimization Program created waste disposition options for project activities. When evaluating waste dispositions, dependency on disposal is reduced when alternatives exist. The idea is to drive waste toward more cost-effective options, such as sanitary waste or reuse. 
Waste minimization accomplishments in 1995 are listed below:

- 109 metric tons (120 tons) of scrap metal were decontaminated and released for resale or recycle through the Material Release Facility;

- One Pollution Prevention Opportunity Assessment was performed on RCRA sample lines;

- The FEMP Reuse Waste Minimization Board realized a cost savings of over $\$ 80,000$;

- 10,000 lbs of aluminum cans were donated to local schools, and over 1,600 laserjet cartridges were sent to a local vendor for refurbishment;

- $10,000 \mathrm{~m}^{3}$ of office paper and cardboard were recycled;

- $34.8 \mathrm{~kg}$ (76.7 lbs) of Freon ${ }_{\mathrm{TM}}$ were recovered or recycled from drinking fountains and air conditioning units;

- Controlled area trash segregation program realized a cost savings of $\$ 162,159.00$.

\section{Natural Resource Management}

The management of natural resources will be an ongoing process as long as there is federal ownership of the site. Natural resources have aesthetic, ecological, educational, historical, recreational, and scientific value to the United States. Discussions on the following topics provide information on the natural resources found on Fernald property:

- ecology;

- threatened and endangered species;

- wetlands;

- foodplains; and

- cultural resources

\section{Ecology}

Representative of the regional ecology, the area's natural vegetation is comprised of a broad-leafed deciduous forest, dominated by maple hardwoods. Some of these naturally wooded areas still exist north of the site and in the Paddys Run (a small creek beginning north of the site and flowing southward along the site's western boundary) watershed to the west. Sixty-two acres immediately north of the production area were planted with white and Austrian pines as part of a 1973 environmental improvement project. Non-native grasslands cover most of the remainder of the site, and local dairy farmers leased site pastures for their herds to graze, consistent with the property's former agricultural uses. The plant diversity provides abundant cover for deer, eastern cottontails, woodchucks, and bobwhite quail; predatory birds, such as red-tailed hawks, have also been observed on Fernald site property. Song sparrows, blue jays, cardinals, and robins nest in the pine plantations, while Paddys Run is home to numerous species of small fish, including minnows, darters, and shiners.

Between 1986 and 1991, biologists from Miami University in Oxford, Ohio, conducted a comprehensive ecological study of the site. In addition to collecting ex- 
tensive ecological baseline data, they also studied plants and animals to determine if any species were being stressed by former site operations. Based on statistical analyses, the study concluded that the site's impact on the natural habitat did not appear to be different from the ecological impact of any other local industrial site.

\section{Threatened and Endangered Species}

The Endangered Species Act states that all federal agencies must seek to conserve federally-listed, threatened, and endangered species. The site conducted surveys in 1994 and 1995 to update information on any threatened or endangered species that may be found onsite. The results of the surveys showed that good to excellent habitat exists along Paddys Run and the Storm Sewer Outfall Ditch for the federally-listed endangered Indiana bat (Myotis sodalis). The surveys also found habitat for the state-listed, endangered cave salamander (Eurycea lucifuga) in one onsite well, an offsite well, and a ravine in the northern section of the site. A population of state-listed, threatened Sloan's crayfish (Orconectes sloanii) was found in the northern sections of Paddys Run. There are also several species of threatened and endangered migratory birds that pass through the site. Some of the birds actually spotted onsite include the northern harrier (Circus cyaneus), northern waterthrush (Seiurus noveboracensis), and dark-eyed junco (Junco hyemalis).

\section{Wetlands}

Wetlands are defined as areas covered or saturated with water for enough time to support water-loving vegetation. A wetland delineation was conducted onsite in December 1992 and January 1993. A total of 15 hectares (36 acres) of freshwater wetlands were delineated. Delineated wetlands included 11 hectares ( 27 acres) of palustrine forested wetlands, 3 hectares ( 7 acres) of drainage ditches/swales, and 1 hectare ( 2 acres) of isolated persistent emergent and scrub/shrub wetlands.

\section{Floodplains}

Floodplains within the Fernald site property are confined to the north-south corridor containing Paddys Run. Outside of the site boundaries, the 100- and 500-year floodplains of the Great Miami River extend west of the Big Bend region, which is east of the site. It also extends northward along Paddys Run from the confluence of the two waterways past the southern boundary of the site.

\section{Cultural Resources}

Factors such as geologic setting, surface waters, soils, vegetation, and climate determine the population and cultural growth of an area. The site and surrounding area are located in a region of rich soil and many sources of water, such as the Great Miami River. As a result, the area has a rich cultural resource diversity. This diversity is evident by the number of historical periods represented in the area's history. These periods include the Paleo-Indian Occupation (12000 BC -8000 BC), Archaic Occupation (8000 BC - $1000 \mathrm{BC}$ ), Woodland Tradition (1000 BC$1000 \mathrm{AD}$ ), Mississippian Tradition (1000 AD - $1660 \mathrm{AD}$ ), and Historic Times (1660 AD - present). 


\section{Local Geography}

A variety of regional physical, ecological, and human characteristics form the context in which environmental monitoring results must be analyzed. By studying various elements of the local geography, scientists and engineers are better able to identify the impact of former production activities. Remedial techniques are then designed to restore the physical environment to its original state or to an established cleanup standard. The following sections describe several of the characteristics of these elements, beginning with the geologic origins of the area.

\section{Geologic History}

About 450 million years ago, in the Late Ordovician period, sediments were deposited in a shallow sea. These sediments solidified over time to become predominantly shale with alternating thin layers of limestone. These strata are known universally as the Cincinnatian Series. The shale is the relatively impermeable bedrock underlying the site.

An ancient river cut into the shale bedrock to about 60 meters ( 200 feet) below the present-day Great Miami River, forming a channel named the New Haven Trough. Later, the Illinoisan and Wisconsin glaciers (about 40,000 years ago and 10,000 years ago, respectively) advanced into the area during the Pleistocene epoch. These glaciers crushed rocks as the ice moved southward from the arctic region. As the glaciers receded, they filled the trough with sand and gravel sediments. ${ }^{3}$

The last of the glaciers in the Fernald area deposited a relatively impermeable glacial till over the sands and gravel. A mix of clay, silt, sand, gravel, and cobbles, this glacial till is unevenly deposited throughout the area and makes up the local overburden.

The Great Miami River and its tributaries have eroded significant portions of the overburden and left terrace remnants, which stand higher than surrounding bottom lands of the river valley. The Fernald site lies on top of one of these terrace remnants, about 177 meters ( 580 feet) above sea level. The property rises to 213 meters ( 700 feet) at the northern boundary of the site and slopes downward to 168 meters (550 feet) at Paddys Run. North and south-southwest of the site, the hills peak at about 260 meters ( 850 feet) and 235 meters ( 770 feet), respectively. The elevation of the Great Miami River, east of the site, is about 165 meters (540 feet), while the land rises gently to about 183 meters ( 600 feet) west of the site. Figure 7 (on page 17) presents a cross-section of the area.

\section{Lithology}

Lithology is the study, classification, and mapping of rocks and rock formations. This science is vital in determining the location, flow, and direction of groundwa- 
Figure 7: Cross-Section of the New Haven Trough, Looking North

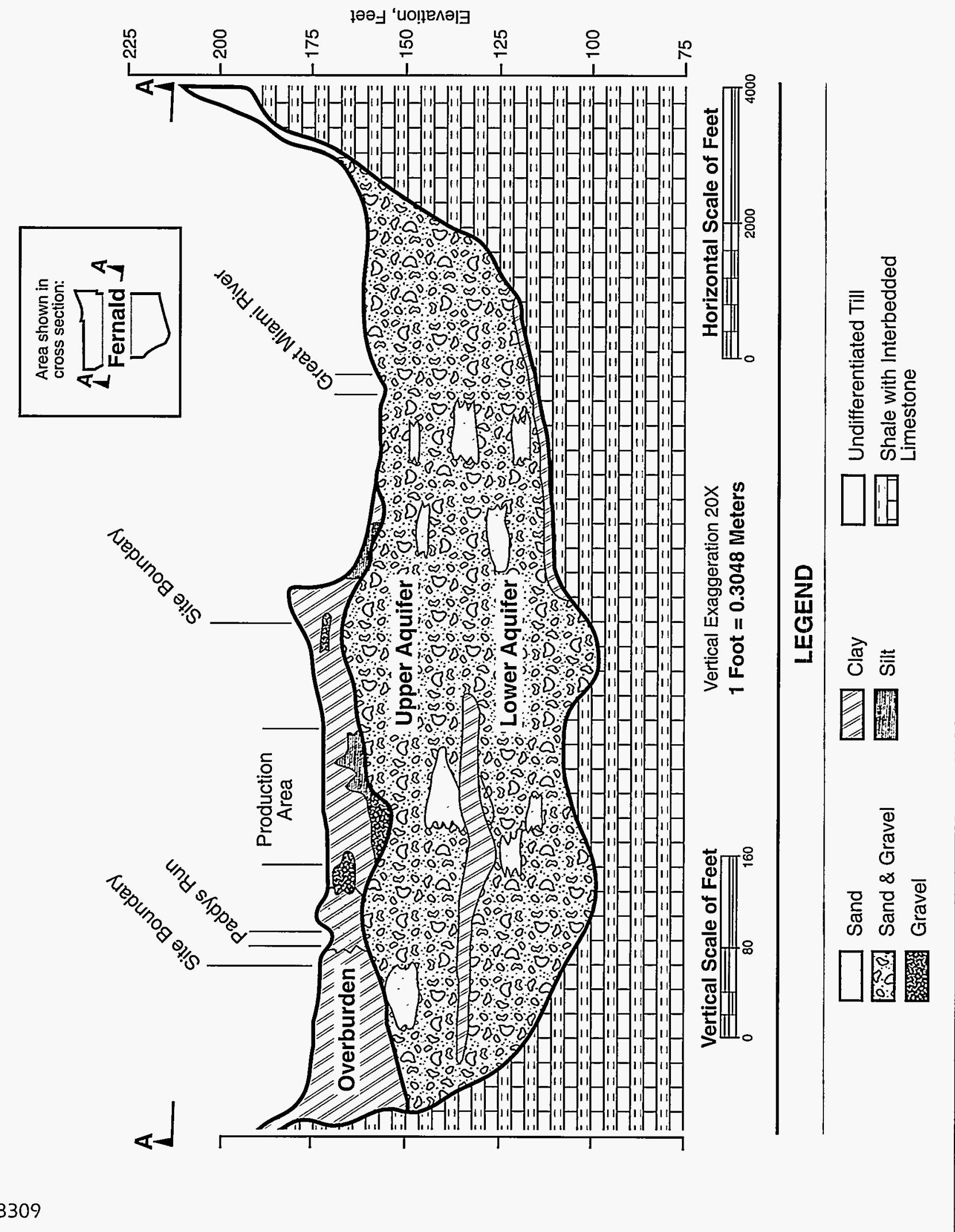


ter. The shale underlying the site forms the floor and valley walls of the New Haven Trough and is generally between 18 and 60 meters ( 60 and 200 feet) below the ground surface. The elevation of the bedrock surface varies from 100 meters (330 feet) above sea level south of the production area to 122 meters ( 400 feet) just north of the site. ${ }^{4}$

The layer of sand and gravel filling the New Haven Trough is up to 60 meters (200 feet) thick. This relatively porous material makes up the Great Miami Aquifer. About 30 to 38 meters (100 to 125 feet) below the surface of the Fernald site, the sand and gravel is divided by a greenish-black silty clay layer, about 3 to 6 meters (10 to 20 feet) thick. ${ }^{4,5}$ Data collected as part of the ongoing Remedial Investigation and Feasibility Study (RI/FS) suggest that the clay layer extends from west of Paddys Run to the center of the production area and is present beneath the waste pit area. The clay layer does not extend east or south of the production area.

A silty clay glacial till overlies the sand and gravel aquifer. This dense overburden, ranging in thickness between 6 and 15 meters ( 20 and 50 feet), varies in composition both vertically and horizontally. The elevation of the base of the overburden is 165 meters (540 feet) above sea level..$^{4,5,6}$ The silty clay overburden continues north and east of the site, where it rests upon the shale bedrock. However, in the lower reaches of Paddys Run and the Storm Sewer Outfall Ditch, the clay has eroded, exposing the underlying sand and gravel and giving the aquifer direct contact with surface runoff.

\section{Groundwater Hydrology}

Hydrology is the study of the properties, distribution, and circulation of water through the local environment. While surface hydrology, discussed in the next section, is the study of drainage systems like rivers, streams, and rainwater runoff, groundwater hydrology focuses on the movement of water below the earth's surface.

Groundwater beneath the site exists in the glacial overburden as perched water in a sand and gravel aquifer and, to a much lesser extent, in the underlying bedrock. Perched water occurs when water sinking through the earth from the surface is trapped above very dense clay. Some of this perched water may slowly seep through the clay, but most remains trapped. At Fernald, perched water is generally found between 0.3 and 3 meters ( 1 to 10 feet) below the surface. Perched water in the glacial overburden occurs sporadically and is not a sufficient source of drinking water. In the overburden, water does not move as easily as water in the sand and gravel aquifer below because most perched water occurs in isolated pockets. ${ }^{7}$

Water sinking through the glacial overburden quickly collects in the sand and gravel aquifer, saturating it. Most water is prevented from sinking further by the nearly impermeable rock floor. The top of the aquifer is about 25 meters ( 82 feet) beneath the site, and the aquifer is between 38 and 53 meters ( 125 and 175 feet) 
thick. As shown in Figure 8 (on the next page), the groundwater in the sand and gravel aquifer is moving east under the waste pit and production areas, while on the southern edge of the facility, groundwater moves generally to the south. These groundwater flow data are used to track and forecast the movement of contaminants that may be found in the aquifer.

There may be groundwater even deeper in the slightly permeable rock layers below the sand and gravel aquifer; however, this water is essentially trapped in cracks and fissures and does not contribute any significant amount to the entire flow system.

\section{Surface Hydrology}

Fernald is part of the Great Miami River drainage basin, although it is above the floodplain (see Figure 9 on page 21). Natural drainage from the site to the Great Miami River is primarily via Paddys Run, a small creek beginning north of the site and flowing southward along the site's western boundary.

This intermittent stream begins losing flow to the underlying sand and gravel aquifer south of the Waste Pits Area. Finally, about $2.4 \mathrm{~km}$ (1.5 miles) south of the site, Paddys Run empties into the Great Miami River.

In addition to natural drainage through Paddys Run, site runoff from the former production area and Waste Pits Area was collected, treated, and discharged to the Great Miami River via the Advanced Wastewater Treatment Facility beginning January 27, 1995. The river, about $1 \mathrm{~km}$ ( $0.6 \mathrm{mile})$ east and south of the site, runs in a southerly direction and flows into the Ohio River about $39 \mathrm{~km}$ ( 24 miles) downstream of the site. Although turbulence makes the Great Miami River unsafe for swimming, some people do fish there. The segment of the river between Fernald and the Ohio River is not designated as a source of public drinking water.

The average flow rate for the Great Miami River in 1995 was 99 cubic meters per second (3,490 cubic feet per second), measured daily approximately $16 \mathrm{~km}$ (10 river miles) upstream of the effluent discharge. Flow rate also fluctuates throughout the year. In 1995, the maximum rate was $909 \mathrm{cms}(32,100 \mathrm{cfs})$ measured in August; the minimum flow was $17 \mathrm{cms}(599 \mathrm{cfs})$ measured in January. ${ }^{8}$

\section{Demography and Land Use}

Scattered residences and several villages, including Fernald, New Baltimore, Ross, New Haven, and Shandon, are located near the site (see Figure 10). Downtown Cincinnati is approximately $27 \mathrm{~km}$ (17 miles) southeast of the site, and the cities of Hamilton and Fairfield are 10 to $13 \mathrm{~km}$ ( 6 to 8 miles) to the northeast. There is an estimated population of 14,600 within $8 \mathrm{~km}$ ( 5 miles) of the site, and an estimated 2.74 million within $80 \mathrm{~km}$ (50 miles). Table 2 on page A-3 shows an estimate of population distribution in the surrounding areas. 


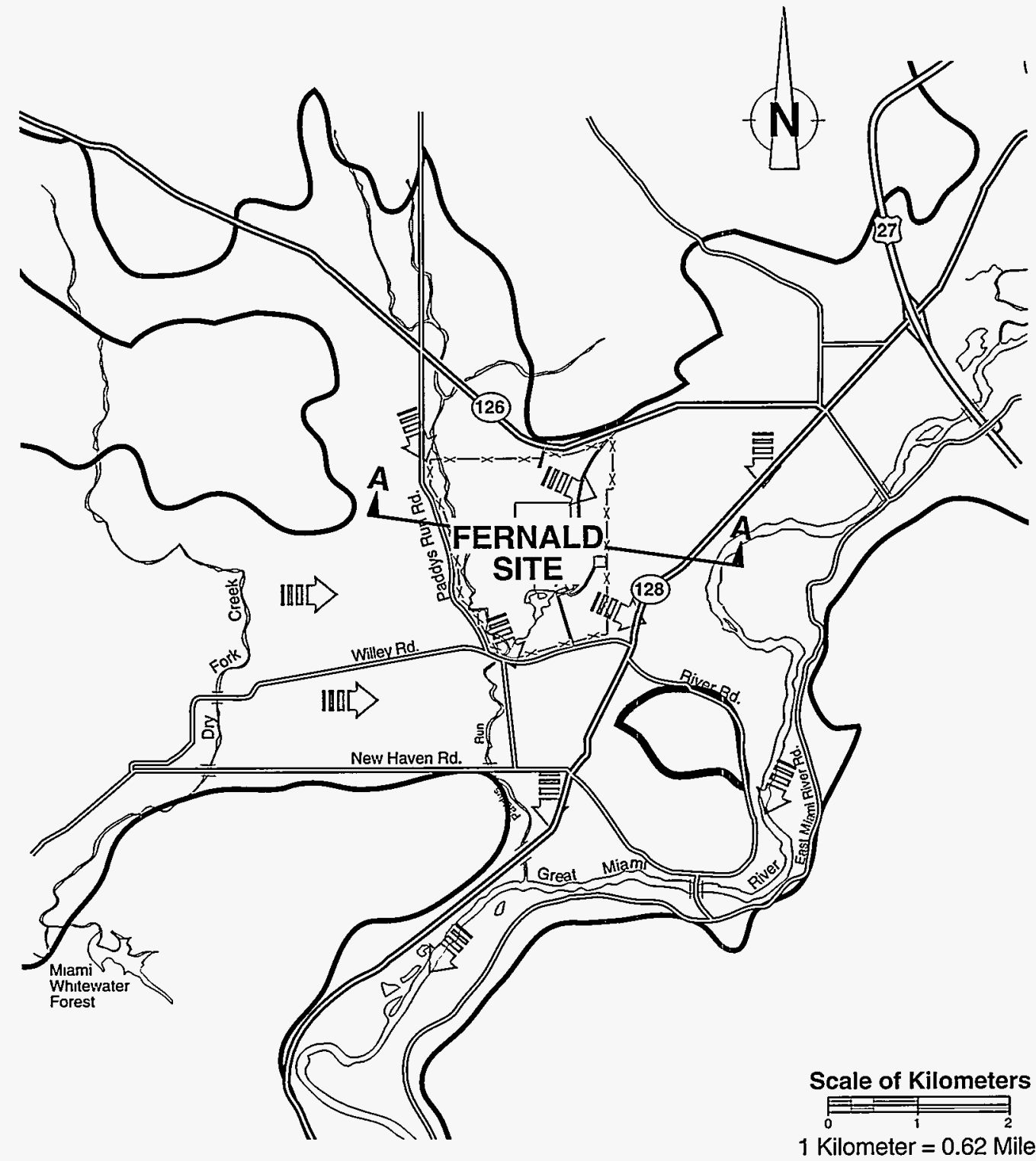

\section{LEGEND}

Buried Valley Aquifer

IIID General Direction of $\times$ - $\times$ Plant Perimeter

A A Location of Cross-Section 


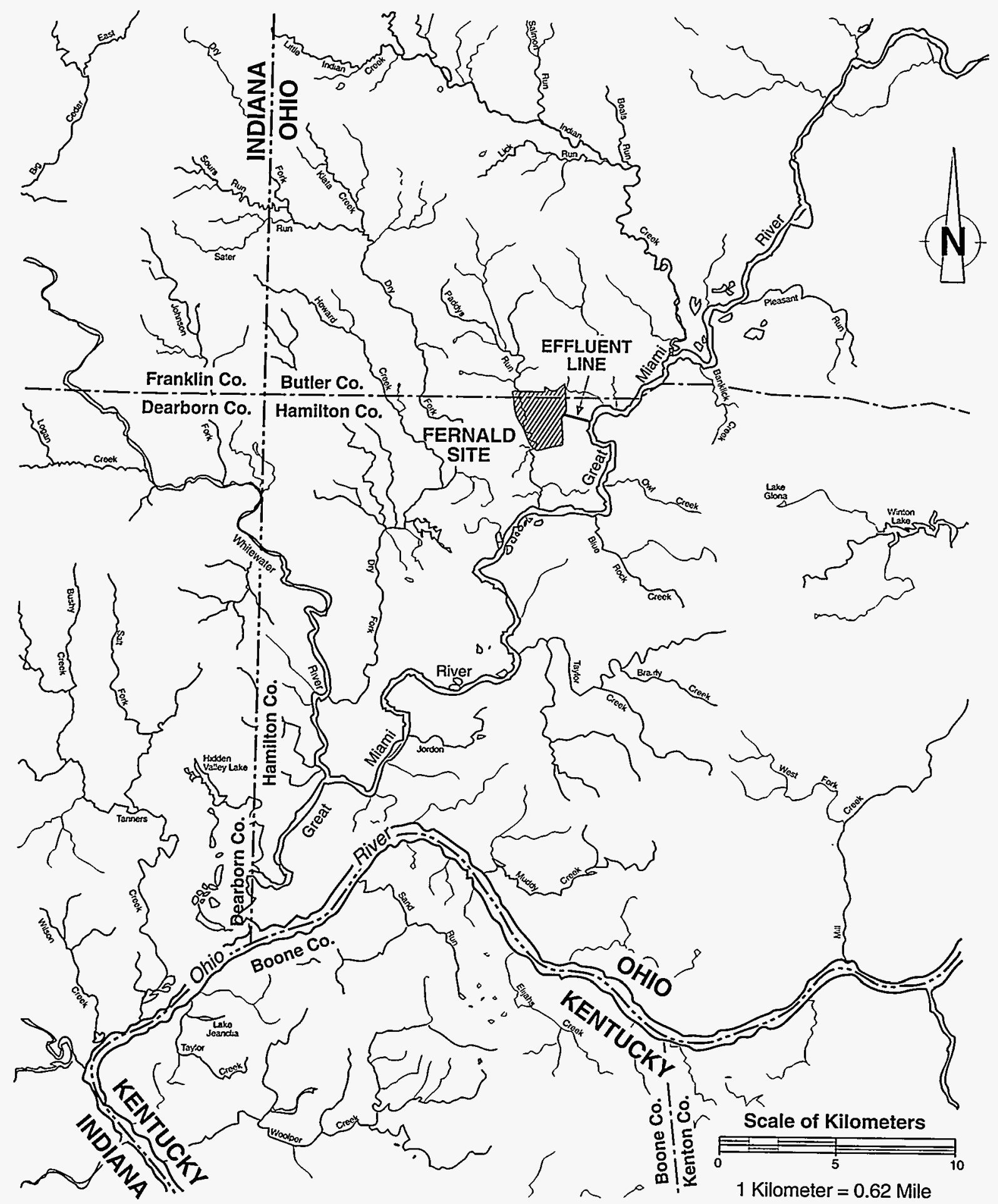


Figure 10: Major Communities in Southwestern Ohio

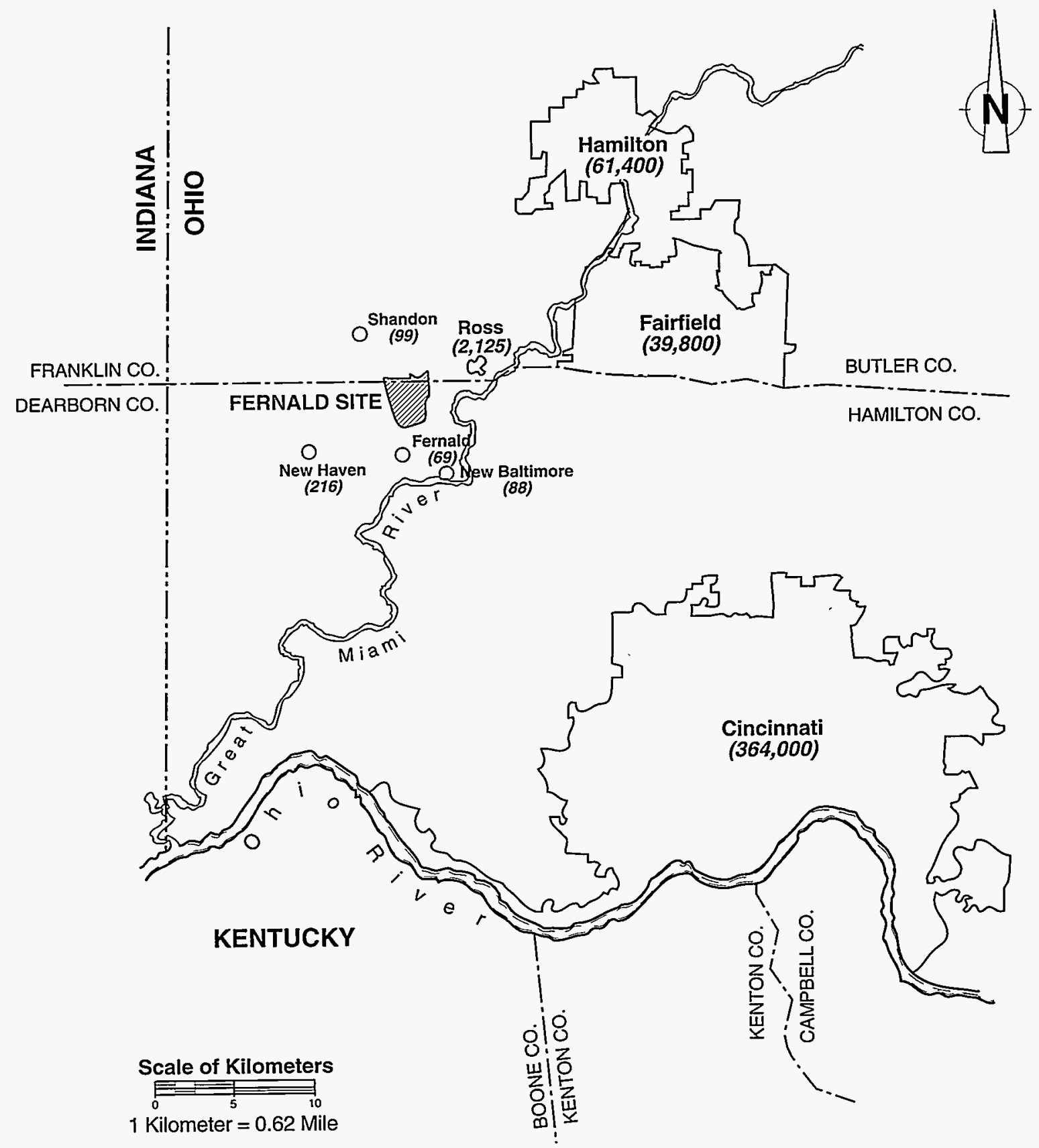

\section{LEGEND}

O Population in parenthesis estimated in 1989

$\square$ Population in parenthesis from 1990 U.S. Census Figures 
The area's major economic activities rely heavily on the physical environment. Farming and raising beef cattle account for the majority of the land use in the area. Major crops include field corn, sweet corn, soybeans, and winter wheat. Several nearby farms also sell produce locally or in nearby urban markets.

Other important commercial products from the area include sand, gravel, and water from the aquifer. Many gravel pit operations exist along the Great Miami River valley. A water company is located $2 \mathrm{~km}$ (1.25 miles) upstream of the site's effluent discharge to the river; presently, this company pumps about $76,000 \mathrm{~m}^{3}$ (20 million gallons) of groundwater per day, for sale primarily to Greater Cincinnati industries.

\section{Exposure Pathways to Humans}

To protect the local environment, the Environmental Monitoring Program focuses on exposure pathways. A pathway is a route by which materials could travel between the point of release and the point of delivering a radiation or chemical dose to a person. These pollutants may reach people directly via a primary pathway, through contaminated air or water, or through a secondary pathway, such as the food chain. One example of a secondary pathway is the air-to-soil-to-rootsto-produce-to-human pathway. In this scenario, a gas or dust particle released from a stack settles on a field or a plant and is absorbed into the soil. A plant may then absorb the pollutant through its roots; the chemical would then pass into the rest of the plant, including the edible portions.

This scenario presents a simplified pathway materials may take. The actual route can be very complex, and the quantity of material that could eventually reach people would be very small. To develop an understanding of the complexity, take another look at the pathway and consider that not all materials released settle out of the air; some fraction may be washed out by rain and enter surface water or groundwater. Of the fraction that does settle, not all falls onto fields, and not all of that fraction on fields is absorbed by the roots of plants. This process of dilution and separation continues until some small fraction of what is released in the air may reach the leaves or fruit of the plant. Although certain plants, animals, and soils may concentrate specific materials and are, therefore, important points in pathways that should be sampled, pathways frequently overlap, and it is difficult to trace them precisely. Environmental sampling and analysis are performed to detect the presence and concentration of pollutants throughout the air and liquid pathways.

Although both radioactive and nonradioactive materials can reach people through the same pathways, the pathway scenarios presented here and throughout the report will focus on radioactive contamination because this is of significant concern at Fernald. Much of this report, as well as the Environmental Monitoring 
Program itself, focuses on radioactive contamination. Uranium is the major radioactive pollutant at the site; however, some of the uranium processed was recycled from nuclear reactors and contains trace concentrations of fission products (such as strontium-90 and cesium-137) and transuranics (such as neptunium-237, plutonium-239, and plutonium-240). These trace nuclides are radioactive and also exist in the environment as a result of fallout from weapons testing and emissions from other nuclear facilities.

To organize the many existing pathways, the Environmental Monitoring Program centers on two major pathways: air and liquid. These pathways provide a basis for the environmental sampling program and direct which environmental samples and models will be used in estimating dose. (Direct radiation, a third pathway, is monitored with radiation detection instruments that measure radiation emitted directly from the site, particularly from the $\mathrm{K}-65$ silos. Direct radiation is discussed further in Chapter Four.) The following sections describe how materials may follow the air and liquid pathways and briefly describe environmental monitoring procedures.

\section{Air Pathway}

The air pathway includes the airborne pollutants that may be carried from the site through emissions and direct radiation (see Figure 11). Stack and building vent

\section{Figure 11 : General Air Pathways to Humans}

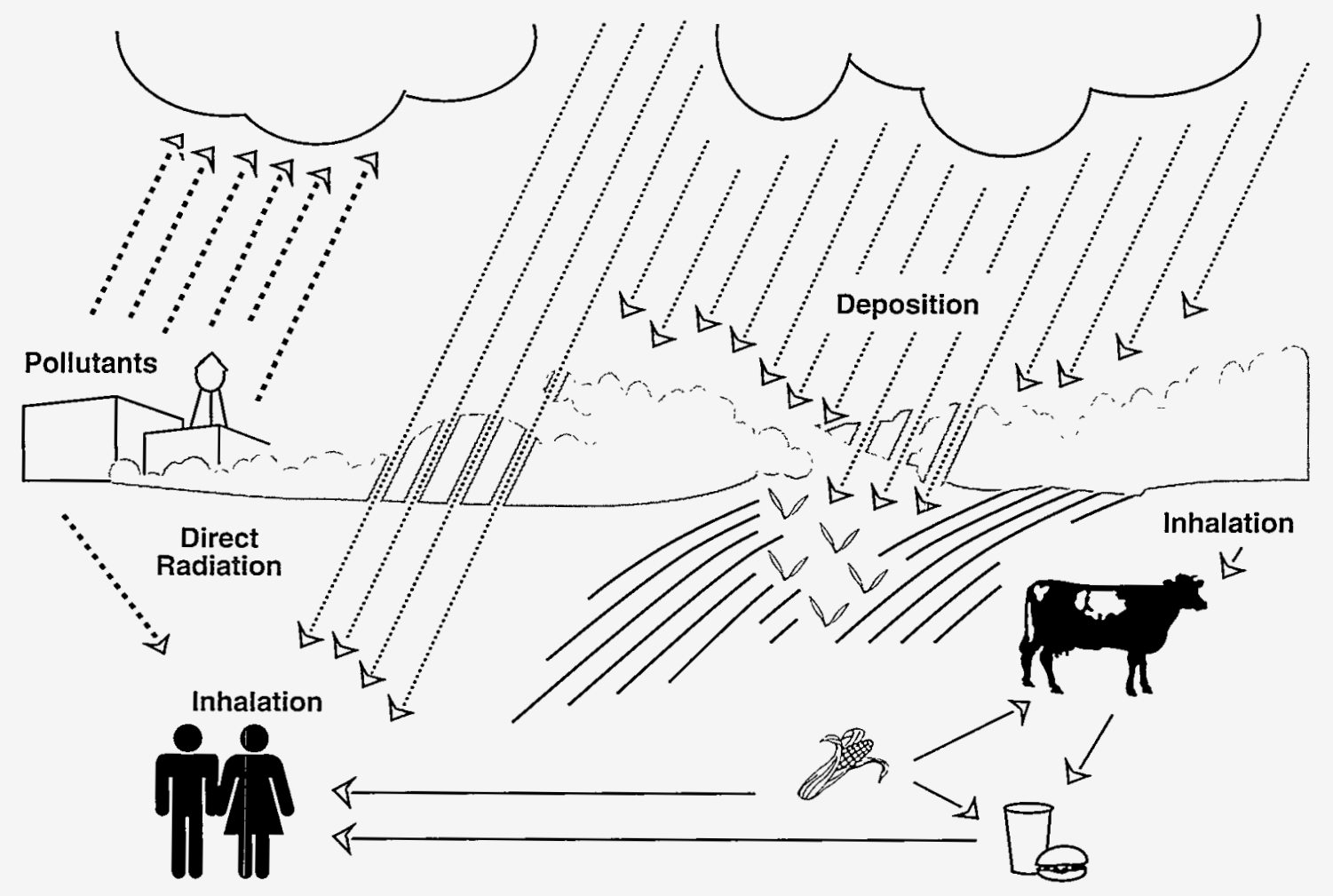


emissions are obvious sources of pollutants, but dust from construction and remediation activities, waste handling, and wind erosion are also potential sources. The form and chemical makeup of pollutants influence how they are dispersed in the environment as well as how they may deliver radiation doses. For example, fine particles and gases may be inhaled, while larger, heavier particles tend to settle and deposit on grass or soil. Chemical properties determine whether the pollutant will dissolve in water, be absorbed by plants and animals, or settle in sediments and soils.

For the environmental scientist, the first step in monitoring the air pathway is to measure the pollutants at the point of release. Measurements may include particle size distributions, chemical form of pollutant, temperature and velocity of the pollutants as it leaves the stack. All of these factors and others can influence dispersion and behavior of pollutants. It is also possible to estimate the concentration of contaminants in the air once the emissions pass through the stack. The site operated 20 air monitoring stations 24 hours a day, seven days a week, during 1995 to monitor these air emissions.

\section{Liquid Pathway}

The liquid pathway includes all releases that could carry waterborne pollutants (see Figure 12). The principal liquid pathways include the effluent discharge line

Figure 12: General Liquid Pathways to Humans

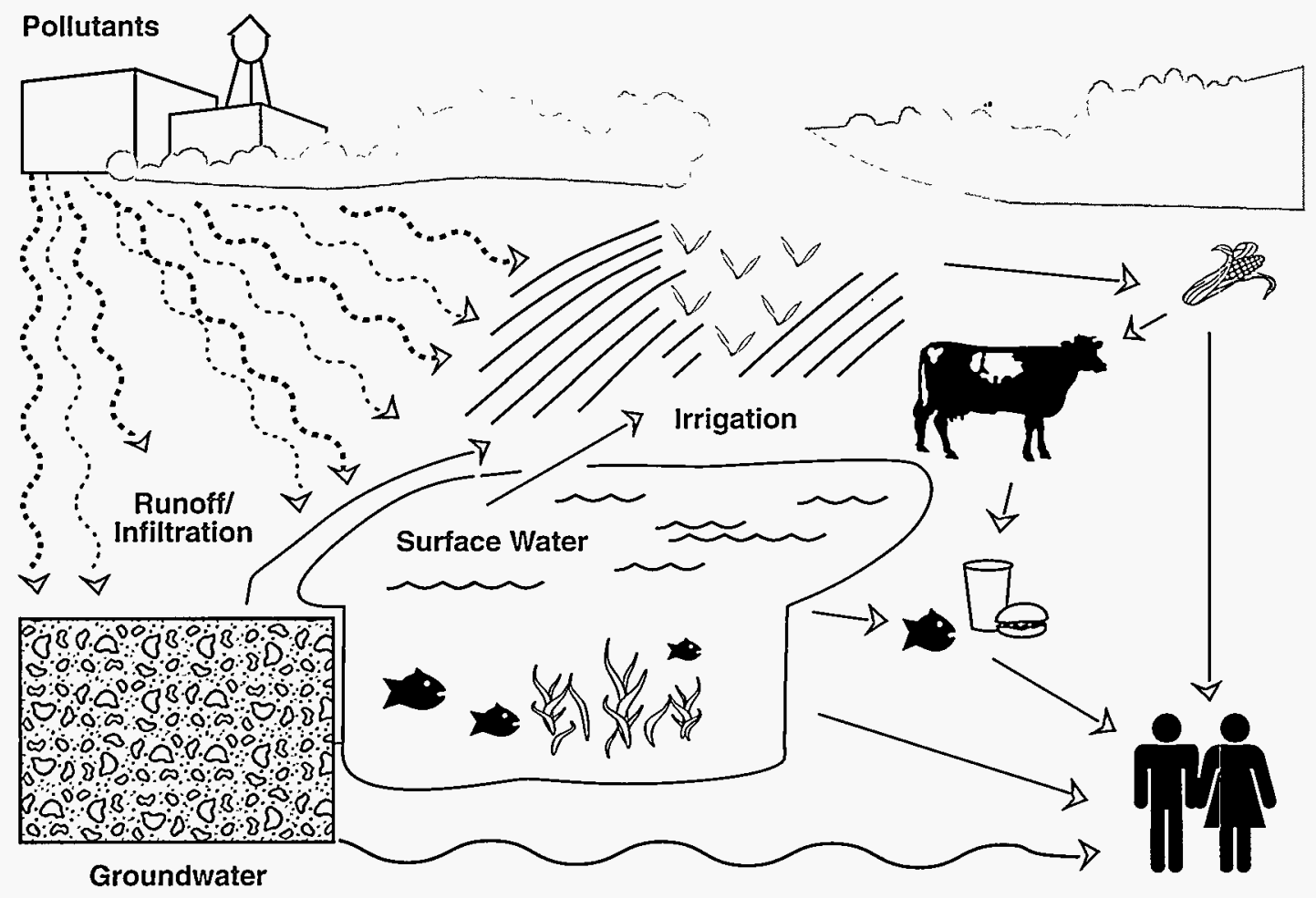


to the Great Miami River, the overflow spillway from the Stormwater Retention Basin, which discharges to Paddys Run, uncontrolled stormwater runoff (much of which also flows to Paddys Run), and groundwater. The first step in monitoring the liquid pathway is to sample the effluent streams as they leave the site. The potential dose that could be delivered via the liquid pathway can be estimated by the type and concentration of each pollutant. Some pollutants in the liquid effluent may be carried along as suspended solids, which eventually settle out as sediment in the stream bed; other pollutants are dissolved in the water and could be absorbed by plants and animals.

Sediment sampling in Paddys Run and the Great Miami River provides information on whether pollutants are accumulating in the stream beds. Fish sampling can show whether pollutants are being absorbed by aquatic animals and how much radioactive material could reach people if they eat fish from the Great Miami River. Fish are known as biological indicators because they can concentrate certain pollutants as they come into contact with them. Therefore, the longer-term influence of the site can be measured through fish sampling.

Groundwater is an important component of the liquid pathway because it is the source of water for homes and farms in the area. Extensive sampling of the wells onsite and in the surrounding area provides information about the aquifer. By sampling the aquifer in many locations and at varying depths, scientists can determine the extent of any contamination.

Each pathway has specific standards and guidelines which define the allowable dose limits for the pathway, and these are discussed in the next section.

\section{Environmental Standards and Guidelines}

As part of data analysis, scientists compare the data to established standards and guidelines whenever possible. These standards and guidelines have been established by many national and international scientific and government groups, including the National Council on Radiation Protection and Measurements (NCRP), the International Commission on Radiological Protection (ICRP), United States Environmental Protection Agency (USEPA), Ohio EPA (OEPA), and DOE. These groups have studied the effects of radioactive and nonradioactive materials moving through the many environmental pathways to people. From this information, standards and guidelines have been established to ensure protection of employees, people in the surrounding communities, and the environment.

DOE adopts standards recommended by various groups of experts and publishes them in DOE orders, thereby establishing the recommendations as limits to be met by DOE facilities. For example, DOE Order 5400.5, Radiation Protection of the Public and the Environment, defines the guidelines for radiation exposure to the public based upon recommendations of the ICRP.,10 Through reports and other 
guidance, the ICRP recommended a system of dose limits. Almost all countries with nuclear programs have adopted these recommendations, which provide a scientific basis for radiological protection and the selection of dose limits.

Once DOE publishes a standard in a DOE Order, such as 5400.5, each DOE site must meet the limits of radiation exposure established in that order. These limits refer to the amount of exposure that a person beyond a facility's boundary could receive from breathing the air or drinking the water. The standards in DOE Order 5400.5 require that routine activities not cause a member of the public to receive an annual effective dose from all radioactive sources (except radon and its decay products) greater than 100 mrem. This dose, known as the primary dose limit, is in addition to natural background radiation. (Chapter Two, Fundamentals of Radiation and Health Hazards, gives basic information about radiation and its measurement.) Underlying all rules and requirements is the philosophy of keeping exposures As Low As Reasonably Achievable ( $A L A R A)$. Therefore, DOE expects doses from its operations to be just a small fraction of the 100 mrem per year limit.

In addition to the requirements of the primary dose limit and the ALARA process, DOE is subject to several pathway and source-specific limits defined in other federal regulations. These imposed dose limits include, but are not restricted to, doses from the air pathway and from the liquid pathway. For example, the Clean Air Act states that the air pathway (air emissions and fugitive emissions from a facility) cannot contribute more than a 10 mrem effective dose in one year to a member of the public. Again, doses from radon and its decay products are covered separately. ${ }^{11}$ For drinking water, DOE operations cannot contribute more than a 4 mrem effective dose in one year to a member of the public. ${ }^{12}$

DOE Order 5400.5 also establishes guidelines for concentrations of radionuclides in air emissions and in liquid effluent. These concentrations, referred to as $D e$ rived Concentration Guidelines (DCGs), are initial screening levels that enable site personnel to review emissions and effluent data and determine if there is a need for further investigation.

The Fernald site follows these standards and guidelines in its daily operations and must provide monitoring results on a regular basis to DOE, USEPA, and OEPA in reports that include the following:

- Annual Radionuclide Air Emissions Report to DOE and USEPA;

- National Pollutant Discharge Elimination System (NPDES) Monthly Discharge Monitoring Report to OEPA;

- Effluent Information System/Onsite Discharge Information System to DOE; and

- Monthly Consent Agreement Report to USEPA.

This SER compares the results of the site's monitoring program to specific standards for various pollutants. Some pollutants do not yet have standards and DCGs 
established. Furthermore, there are instances where standards do not exist for specific media, such as uranium in soil, grass, produce, or fish. Where no standards or guidelines are available, other points of reference are presented in order to help the reader assess the impact of site operations. For example, results are compared with background data from areas unaffected by the site activities. Fernald scientists look for trends by comparing results from 1995 with results from previous years.

The remainder of this report discusses some basic facts about radiation and other health hazards, compliance activities, and the Environmental Monitoring Program for 1995. 

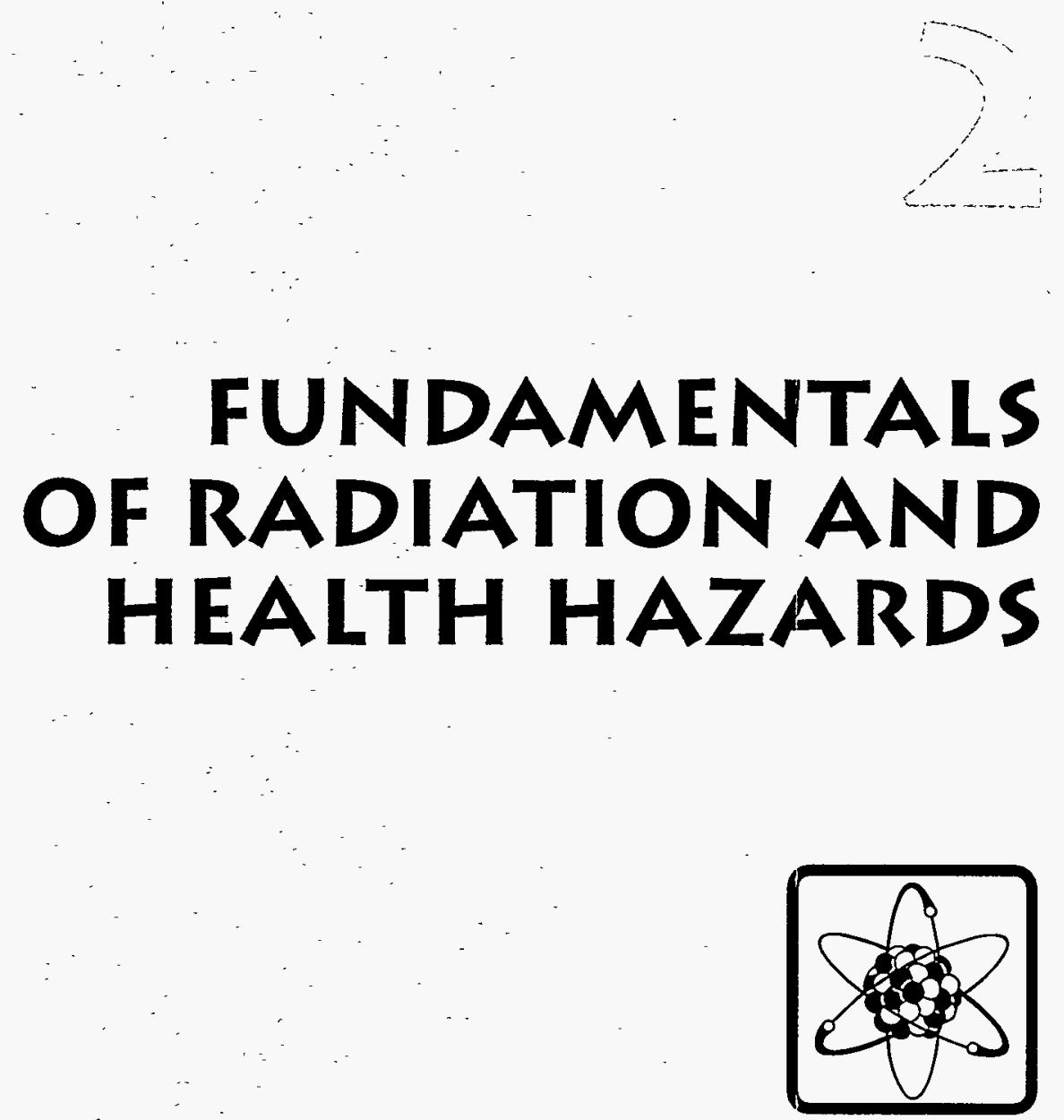



\section{Fundamentals of Radiation and Health Hazards}

Since radioactive materials and hazardous chemicals are stored at the Fernald site, it is important to understand the possible health hazards associated with these materials. Also, terms unique to radiation and its potential health effects are used extensively throughout this report. As a result, some of the important information in the report may be difficult for the non-scientist to interpret. This chapter provides a way to put that information into perspective and includes the following topics:

- The atom,

- Radioactivity and radiation,

- The units used to measure radiation,

- Background radiation,

- The effects of radiation,

- Definitions of terms,

- Laws regulating health hazards, and

- Types of health threats.

Readers who are already familiar with the concepts and terms used in the study of radiation and other health hazards may wish to proceed directly to Chapter Three, the Environmental Compliance Summary. 


\section{The Atom}

The world is made up of atoms. Atoms consist of two basic parts:

- The nucleus, and

- The electrons orbiting the nucleus.

The nucleus is made up of protons, which are positively charged, and neutrons, which have no charge. Protons and neutrons are similar in size, and both are considerably larger than electrons (about 1,800 times more massive). Therefore, the weight and mass of the atom is principally concentrated in the nucleus. The electrons circling the nucleus have a negative charge. Atoms tend to move toward a

Figure 13: Structure of the Atom

The Nucleus of an Atom The nucleus has many protons (white) and neutrons (orange). Notice that there are never two protons touching each other. Similar to a magnet, the positively charged protons repel each other. There must be neutrons separating the protons.

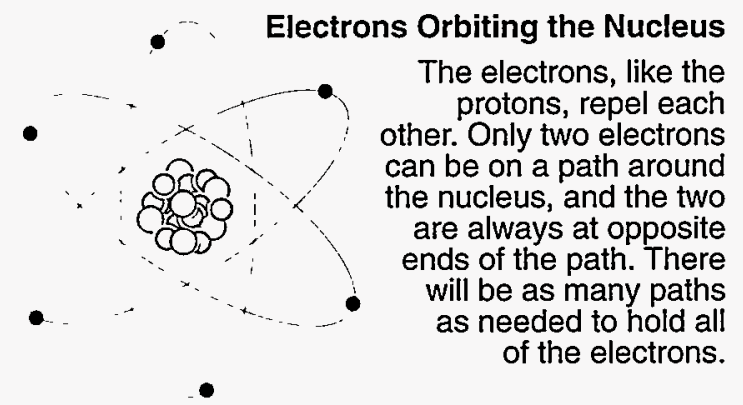

The Hydrogen Nucleus

The hydrogen nucleus always has one proton and can have zero, one or two neutrons. The protons are

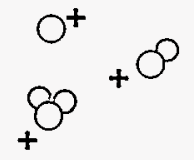
positive and the neutrons are neutral.

\section{The Hydrogen Atom}

The hydrogen atom consists of the nucleus and the electron orbiting the nucleus. Since the hydrogen atom has one proton, it must have one electron to be electrically neutral. neutral state in which the negative electrical charge of the orbiting electrons balances the positive charge of the nucleus. To keep the atom electrically neutral, the number of electrons in an atom must equal the number of protons (see Figure 13).

Protons and electrons have many characteristics similar to magnets. Just as opposite magnetic poles are drawn toward each other, protons and electrons are attracted toward each other. This attraction keeps the electrons orbiting around the nucleus. The electrons are not pulled into the nucleus because of the electrons' energy, which keeps them constantly moving and away from the protons. The energy in the electrons and the attraction of the electrons to the protons balance each other and keep the electrons in orbit. Just as energy in the electrons keeps them orbiting, energy in the nucleus keeps the protons and neutrons together.

The number of protons in the nucleus is referred to as the atomic number, and it is the identifier of the atom. If the atomic number changes, then the number of electrons and the chemical properties of the atom change. For example, for an atom to be hydrogen, it must have one proton. If a hydrogen atom were to gain a proton, it would no longer be hydrogen; it would be helium, which has two protons. Uranium, the substance of most concern at this site, has 92 protons. Since protons are positively charged, the atom must also have 92 electrons for it to be electrically neutral. 
The sum of the protons and neutrons in the nucleus is called the mass number. Unlike protons, the number of neutrons contained in a specific atom can vary since neutrons have no charge and do not need to be balanced by electrons. Therefore, the mass number can vary. For example, a hydrogen atom always has one proton, but it can have either zero, one, or two neutrons. The different hydrogen atoms are called isotopes of hydrogen. Isotopes are labelled with their mass number. A hydrogen atom without a neutron is referred to as hydrogen, where 1 is the mass number. The hydrogen isotope with one neutron is referred to as Deuterium, and the isotope with two neutrons is referred to as Tritium.

Most of the uranium at the Fernald site contains 146 neutrons to go with the 92 protons present in every uranium nucleus; therefore, the mass number is 238 (146 neutrons +92 protons $=238$ ). Uranium- 234 has 142 neutrons +92 protons; uranium-235 has 143 neutrons + 92 protons; and uranium-236 has 144 neutrons + 92 protons. All isotopes of uranium are radioactive. Radioactivity and radiation are described in the next section.

\section{Radioactivity and Radiation}

Radioactivity is a process in which a nucleus of an unstable atom spontaneously decays or disintegrates. Radiation is the energy that is released as particles or waves when the disintegration or decay of the nucleus occurs. This section includes a discussion of radioactive decay and the three main forms of radiation at the FEMP produced by radioactive decay:

- Alpha particles,

- Beta particles,

- Gamma rays.

It should be noted, however, that not all radioactive substances emit all three types of radiation. The differences between alpha particles, beta particles, and gamma rays will be clarified in the discussions that follow.

\section{Radioactive Decay}

Atoms are radioactive because of the number of protons and neutrons or because they have too much energy to remain stable. By emitting radiation, the nucleus releases energy and moves toward a more stable, less energetic state and eventually becomes a stable atom. Radioactive decay occurs everywhere on earth because of naturally occurring radioactive elements. When most radioactive elements decay, the resulting atom is also radioactive. This is called a radioactive decay chain. There are four natural radioactive decay chains. A common chain begins with uranium-238 and ends with non-radioactive lead-206 (this isotope of lead is stable, which means it does not decay). Each of the various radioactive atoms (radionuclides) created during the decay sequence has its own natural rate of decay. 
The amount of time it takes for a radioactive substance to lose half of its radioactivity, or for half to become the next element in the chain, is its half-life. All decay chains found in nature begin with an isotope with an extremely long half-life. It is assumed that these atoms were formed at the same time as all the other atoms on earth and are still present because their half-lives are comparable to the age of the earth.

The uranium decay sequence is common in nature and at the Fernald site. (The uranium and thorium decay chains are presented on the next page and in Figure 49: Decay Chains, Chapter 8.) Uranium-238 emits an alpha particle (two protons and two neutrons) and becomes thorium-234. Then a neutron in thorium-234 becomes a proton and an electron. The electron is emitted as a beta particle and additional energy is given off in the form of a gamma ray. Then thorium-234 decays to protactinium-234. The decay process proceeds in this manner until the element becomes stable as lead-206. Much of the uranium and thorium at the Fernald site has been chemically purified and separated from other elements shown in the decay series. Elements separated from uranium and thorium are some of the wastes stored onsite. The material stored in the $\mathrm{K}-65$ silos (radium$226)$ is an example of such waste.

\section{Addressing Homeowner Concerns about Uses of W/ell Water}

Several homeowners near the Fernald site have expressed concern as to why well water with low concentrations of natural uranium may be acceptable for household utility uses such as washing clothes, bathing, and watering plants, but may not be acceptable for drinking or cooking. To some, this may seem inconsistent and cause misunderstanding.

The key to understanding why the water is acceptable for external uses is an understanding of how alpha particles, of prime concern when dealing with uranium, deliver a radiation dose. Alpha particles are large, charged particles that readily interact with other materials. This interaction prevents the particles from ever penetrating very deeply. Even the most energetic alphas from uranium are stopped by the outer layers of dead skin.

However, inside the body, there are no protective dead cell layers to prevent the alpha particles from interacting with live organ cells; all emitted energy is delivered as dose to the organ. The alpha-emitting radionuclide may also be incorporated into specific kinds of cells, depending on its chemical properties. For example, the body processes several radionuclides as though they were calcium; predictably, they end up being deposited in the bones. Research has shown that uranium tends to concentrate in the bone and, to a lesser extent, in the liver, kidneys, and other tissues.

Independent of its associated radiation hazards, uranium also has a chemical toxicity. Studies on animals have indicated that uranium is toxic to the kidney at concentrations of approximately $70,000 \mathrm{pCi} / \mathrm{L} .{ }^{13}$

Although the concentrations of concern in these studies are several thousand times greater than the concentration of uranium in local groundwater, it is desirable to limit the intake of uranium. While no measurable increase in health effects can be expected by drinking water with slightly higher than typical background concentrations of uranium, decreasing the amount of uranium ingested may provide valuable peace of mind to those concerned. And, even with slightly higher uranium concentrations, the water is still acceptable for external, household utility use. 
Nuclides

of the Uranium

Decay Chain

Nuclides

of the Thorium

Decay Chain

\begin{tabular}{|c|c|c|}
\hline Isotope & Half-life & Radiation \\
\hline Uranium-238 & $4,500,000,000$ years & alpha \\
\hline Thorium-234 & 24 days & beta, gamma \\
\hline Protactinium-234m & 1.2 minutes & beta, gamma \\
\hline Uranium-234 & 250,000 years & alpha, gamma \\
\hline Thorium-230 & 80,000 years & alpha, gamma \\
\hline Radium-226 & 1,622 years & alpha, gamma \\
\hline Radon-222 & 3.8 days & alpha \\
\hline Polonium-218 & 3.05 minutes & alpha \\
\hline Lead-214 & 26.8 minutes & beta, gamma \\
\hline Astatine-218 & 2.0 seconds & alpha \\
\hline Bismuth-214 & 19.7 minutes & beta, gamma \\
\hline Polonium-214 & 0.000164 second & alpha. gamma \\
\hline Thallium-210 & 1.3 minutes & beta, gamma \\
\hline Lead-210 & 22 years & beta, gamma \\
\hline Bismuth-210 & 5.0 days & beta \\
\hline Polonium-210 & 138 days & alpha. gamma \\
\hline Thallium-206 & 4.2 minutes & beta \\
\hline Lead-206 & Stable & none \\
\hline Isotope & Half-life & Radiation \\
\hline Thorium-232 & $14,000,000,000$ years & alpha \\
\hline Radium-228 & 6.7 years & beta \\
\hline Actinium-228 & 6.13 hours & beta, gamma \\
\hline Thorium-228 & 1.9 years & alpha, gamma \\
\hline Radium-224 & 3.64 days & alpha, gamma \\
\hline Radon-220 & 55 seconds & alpha \\
\hline Polonium-216 & 0.16 second & alpha \\
\hline Lead-212 & 10.6 hours & beta, gamma \\
\hline Bismuth-212 & 60.5 minutes & alpha, beta, gamma \\
\hline Polonium-212 & 0.000000304 second & alpha \\
\hline Thallium-208 & 3.1 minutes & beta, gamma \\
\hline Lead-208 & Stable & none \\
\hline
\end{tabular}

EXAMPLE To illustrate the idea of half-life, let's look at the isotope thorium-234. Its half-life is 24 days. If you started with 1,000 atoms of thorium-234, after 24 days you would have 500 . The other 500 atoms would have decayed into protactinium$234 \mathrm{~m}$. After another 24 days you would have 250 , and so on. The half-life of some isotopes, such as uranium-238, is very long. The middle column in the uranium and thorium decay chain examples contains the half-life periods of the elements in the decay chain. All the radionuclides in the Uranium Chain can be thought of as "potential" lead-206 atoms. This will be the case many billions of years into the future when all natural radioactive isotopes will have decayed to their stable end products. 


\section{Alpha Particles}

Alpha particles consist of two protons and two neutrons and have a positive charge. Because they are charged, they interact with other atoms by scattering off other charged particles, or depositing their energy by interacting with the material. Moreover, because of their large size and charge, alpha particles do not travel very far when emitted -

\section{Figure 14: Types of lonizing Radiation}

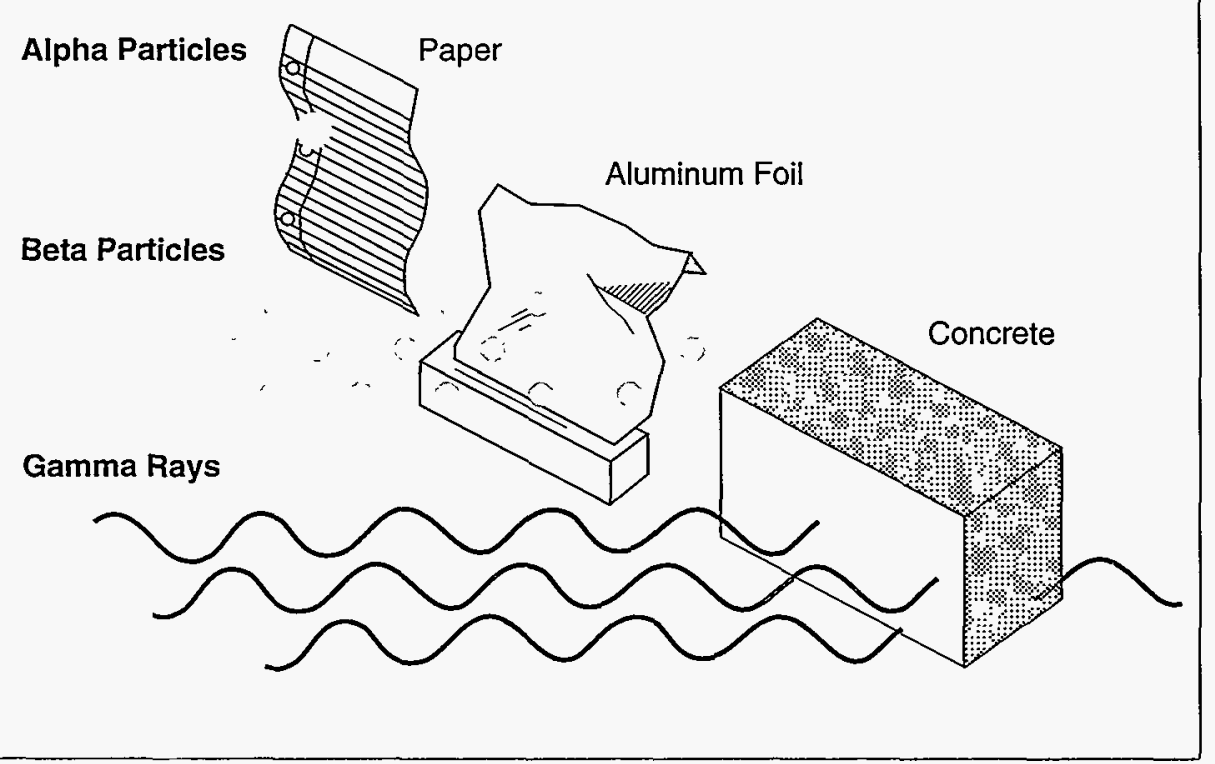

1 to 8 centimeters

( 0.4 to 3 inches) in air.

They are unable to penetrate any solid material, such as paper or skin, to any significant depth (see Figure 14). However, if alpha particles are released inside the body, they can damage the soft internal tissues because they deposit all their energy in a very small volume. Uranium decays by emitting alpha particles, so if uranium particles are inhaled or swallowed, the emitted alpha particles may damage internal tissue. Some other radionuclides present at the Fernald site that decay by emitting alpha particles include thorium-228, -230 , and -232 .

\section{Beta Particles}

Beta particles are electrons that carry a negative electrical charge. They are much smaller than alpha particles and travel at nearly the speed of light; thus, they can travel approximately 2 to 4 meters ( 6 to 12 feet) in air and, as shown in Figure 14, penetrate solid materials about $1 \mathrm{~cm}(0.4 \mathrm{inch})$. Beta particles interact with other atoms in ways similar to alpha particles, but because they are smaller, faster, and have less charge, they cause less concentrated damage when interacting with tissue. Thorium-234, a decay product of uranium-238, emits beta particles.

\section{Gamma Rays}

Gamma rays are bundles of electromagnetic energy which behave as though they were particles. These pseudo-particles are called photons. They are similar to visible light, but of a much higher energy. For example, $\mathrm{X}$-rays are a type of high-energy electromagnetic radiation, and excessive exposure to X-rays can damage the body. Gamma rays are generally more energetic than X-rays. They can travel long distances and can penetrate not only skin, but also, depending on 
their energy, can penetrate substantial distances into solid materials such as concrete or steel (see Figure 14). Gamma rays are often released during radioactive decay along with alpha and beta particles. Some of the materials stored in the $\mathrm{K}-65$ silos decay by emitting gamma rays. Potassium- 40 is an example of a naturally occurring radionuclide found in all human tissue that decays by emitting a relatively high-energy gamma ray. The typical human body contains about 110,000 picocuries of potassium-40. (Units of radiation are discussed below.)

\section{Interaction with Matter}

When radiation interacts with other materials, it affects the atoms of those materials principally by knocking the negatively charged electrons out of orbit. This causes the atom to lose its electrical neutrality and become positively charged. An atom that is charged, either positively or negatively, is called an ion. Anything that creates an ion is said to be ionizing.

\section{Units of Measurement}

To measure the effect of radiation, scientists have developed ways to measure levels and intensity of radiation. Some of these measurement units are technical and may require some explanation. Additional terms are included in the glossary of this report (see Appendix E).

\section{Activity}

Activity is the number of nuclei in a material that decays per unit of time. An amount of radioactive material that decays at a rate of 37 billion atoms per second has an activity of one Curie (Ci). Smaller sub-units of the Curie are often used in

\section{Figure 15: Comparison of Disintegration Rate*}

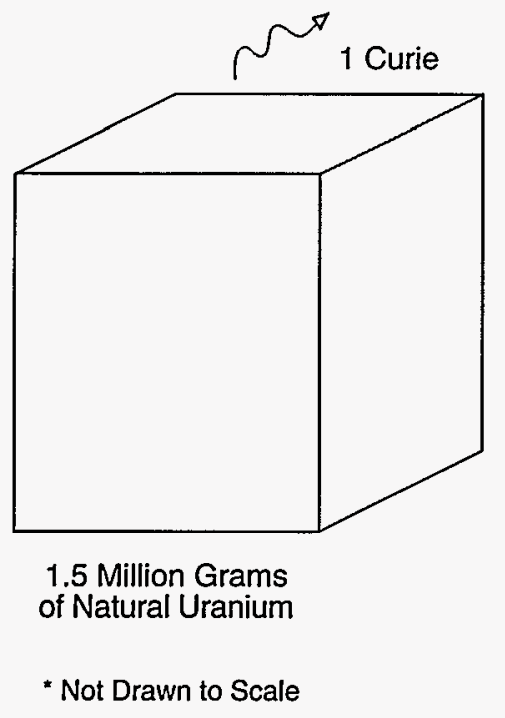
this report. Two common units are the microcurie $(\mu \mathrm{Ci})$, one millionth of a Curie, and the picocurie $(\mathrm{pCi})$, one trillionth of a Curie. The amount of radioactive material required to emit one Curie depends on the disintegration rate. For example, about one gram of radium-226, with a half-life of 1,622 years, emits one Curie of activity. On the other hand, it would require about 1.5 million grams of natural uranium, which has a half-life of 4.5 billion years, to equal one Curie because natural uranium is less radioactive than radium-226. Radon-222, with a half-life of only 3.8 days, is even more radioactive than radium-226, and only 0.0000065 gram of radon-222 is needed to equal one Curie (see Figure 15). 


\section{Dose Equivalent}

When a person comes into contact with radiation, that person has been exposed to radiation. Dose equivalent is a measure of the amount of radiation that is delivered to the body. Alpha, beta, and gamma radiation affect the body to different degrees. To take these different effects into account, each type of radiation is assigned a quality factor $(\mathrm{QF})$. The more damaging the type of radiation, the higher the QF. For beta and gamma radiation, the $\mathrm{QF}$ is one. For alpha radiation, the $\mathrm{QF}$ is 20 . The $\mathrm{QF}$ number is multiplied by an absorbed dose to calculate an exposed person's dose equivalent. Dose equivalent is used when comparing the effects of different types of radiation. The Roentgen equivalent man (rem) unit is used to express dose equivalent. The more rem, the higher the potential damage. Because the amount of radiation we receive from background and the Fernald site is so small, millirem (mrem) is often used instead of rem. One mrem is equal to $1 / 1000$ of a rem.

The term dose is used in four different ways in this report: organ dose, effective dose, committed effective dose, and whole body dose.

In this report, we use the term dose frequently. Unless specified differently, that term will be used in place of the term dose equivalent.
The organ dose is the amount of radiation received by an individual organ in the body. The amount of radiation any organ will absorb depends upon a variety of factors (for example, the way the radiation entered the body and the type of radiation). Therefore, when discussing the organ dose, scientists often refer only to the organ of greatest importance called the critical organ. The critical organ varies from situation to situation. It is determined based on things such as the amount of radiation received, the chemistry of the radionuclide, the sensitivity of that organ to the particular form of radiation, and the importance of that organ to the body. Based on the radionuclides found onsite, scientists have identified the critical organs as the lung, kidney, and bone surface (endosteum). Figure 16 shows which organs are most affected by various substances found at the site.

The effective dose expresses how much of a health risk radiation doses pose to individuals. To determine the effective dose, scientists first estimate each organ dose. Then, because some organs are more sensitive to radiation than others, the organs are given different weighting factors (see shaded box on the next page), similar to quality factors. The greater the risk an organ has of developing cancer and the more important that organ is to human health, the higher the weighting factor. The weighting factor is multiplied by the organ dose for each organ. These numbers are then added together to give the effective dose.

The National Council on Radiation Protection and Measurements (NCRP) and International Commission on Radiological Protection (ICRP) recommend that an individual not be exposed to more than 100 mrem effective dose per year for all pathways (over and above the amount a person receives from background and 
medical radiation). This recommendation applies to the general public for long-term, continuous exposures. ${ }^{14}$ The DOE guideline for dose to members of the public is 100 mrem per year from all

\section{Figure 16: Organs Affected by Substances} Found at the Fernald Site

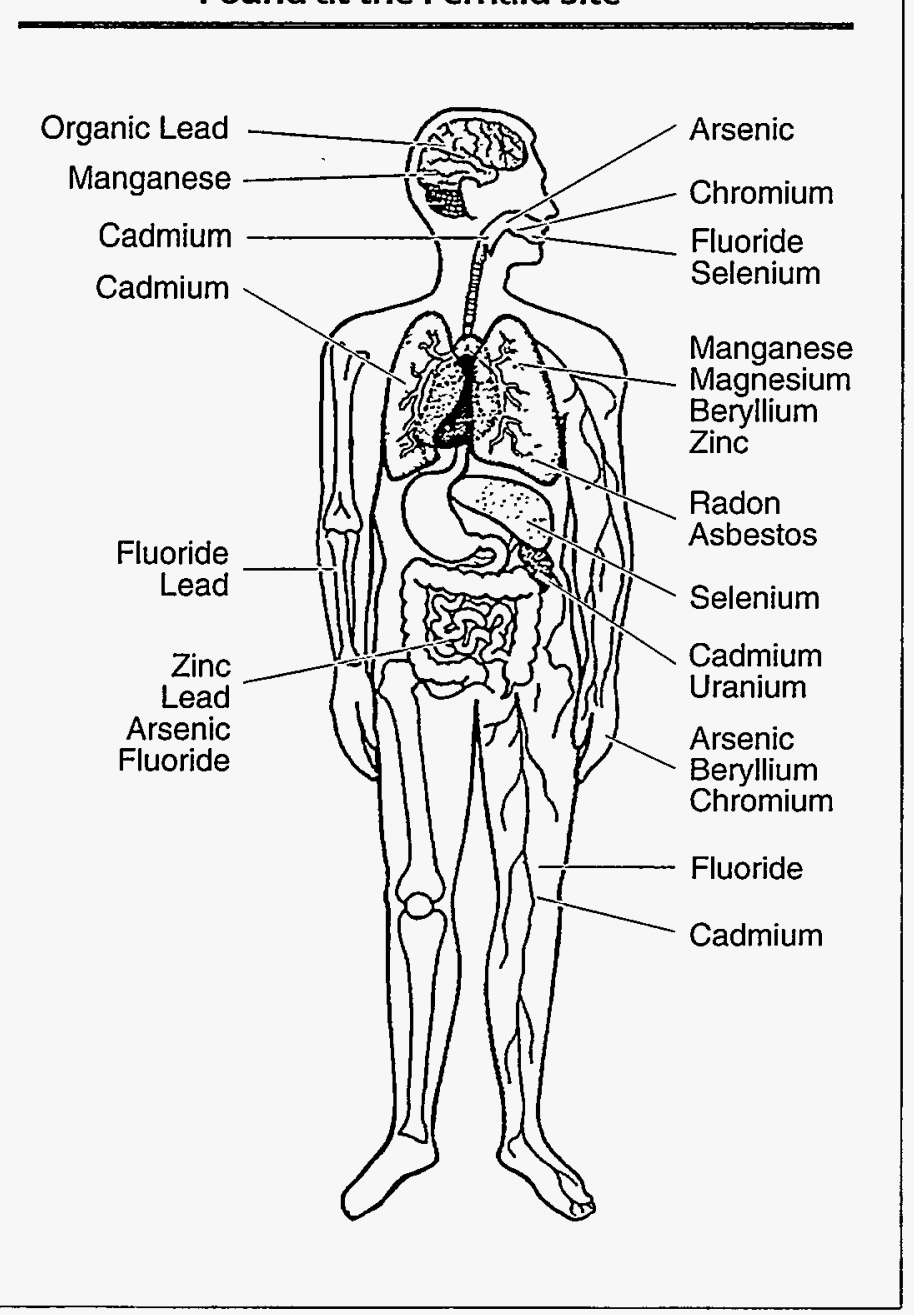

pathways (excluding radon). The National

Emission Standards for Hazardous Air Pollutants (NESHAP) limit for effective dose is 10 mrem per year from radionuclides (except radon) released via the air pathway. ${ }^{11}$

The committed effective dose is the total amount of radiation an individual receives over a specified period of time from radioactive materials inside the body. When a person breathes or eats something that contains radioactive materials, the radiation within those materials is not all released at once. Half of the radiation is released over a period of time equal to the half-life of the radioactive material. Meanwhile, the body excretes radioactive materials at various rates determined by the individual's metabolism and the biochemistry of the radioactive material. Scientists have developed the concept of the committed effective dose to estimate the total amount of radiation one will receive over time (generally a 50-year period) from the radioactive materials taken into the body in a given time period.

The whole body dose is the amount of radiation an individual receives when the entire body is irradiated evenly by direct (gamma) radiation. The majority of the dose recorded at the Fernald site is a whole body dose due to external radiation.

\begin{tabular}{cc} 
Organ or Tissue & Weighting Factor \\
\hline Gonads & 0.25 \\
\hline Breasts & 0.15 \\
\hline Red Bone Marrow & 0.12 \\
\hline Lungs & 0.12 \\
\hline Thyroid & 0.03 \\
\hline Bone Surfaces & 0.03 \\
\hline Remainder & 0.30 \\
\hline
\end{tabular}

In the chart at left, "Remainder" means the five other organs with the highest dose (e.g., liver, kidney, spleen, thymus, adrenal, pancreas, stomach, small intestine, or upper and lower large intestine. but excluding skin, lens of the eye, and extremities). The weighting factor for each of these organs is 0.06 . Thus, the collective weighing factor of these five organs making up "Remainder" is 0.30 . 


\section{Exposure to Background Radiation}

The dose terms defined in the preceding paragraphs apply to more than just the radiation we may be exposed to from facilities like the Fernald site. All people are constantly exposed to other background and man-made sources of radiation. Such radiation includes the decay of radioactive elements in the earth's crust, a steady stream of high-energy particles from space called cosmic radiation, naturally occurring radioactive isotopes in the human body (like potassium-40), medical procedures, man-made phosphate fertilizers (phosphates and uranium are often found together in nature), and even household items like televisions. ${ }^{15}$ In the United States, a person's average annual exposure to background radiation is 360 mrem. ${ }^{14}$ The DOE guidelines (as well as other radiological guidelines) apply to exposure individuals receive in addition to background radiation and medical procedures.

As the Exposure to Background Radiation Chart shows, radon is the largest contributor to background radiation (see Figure 17). At an average of 200 mrem per year, naturally occurring radon accounts for more than half of the background dose in the United States. ${ }^{10}$ (Radon is discussed further in Chapter Eight.)

Figure 17: Exposure to Background Radiation

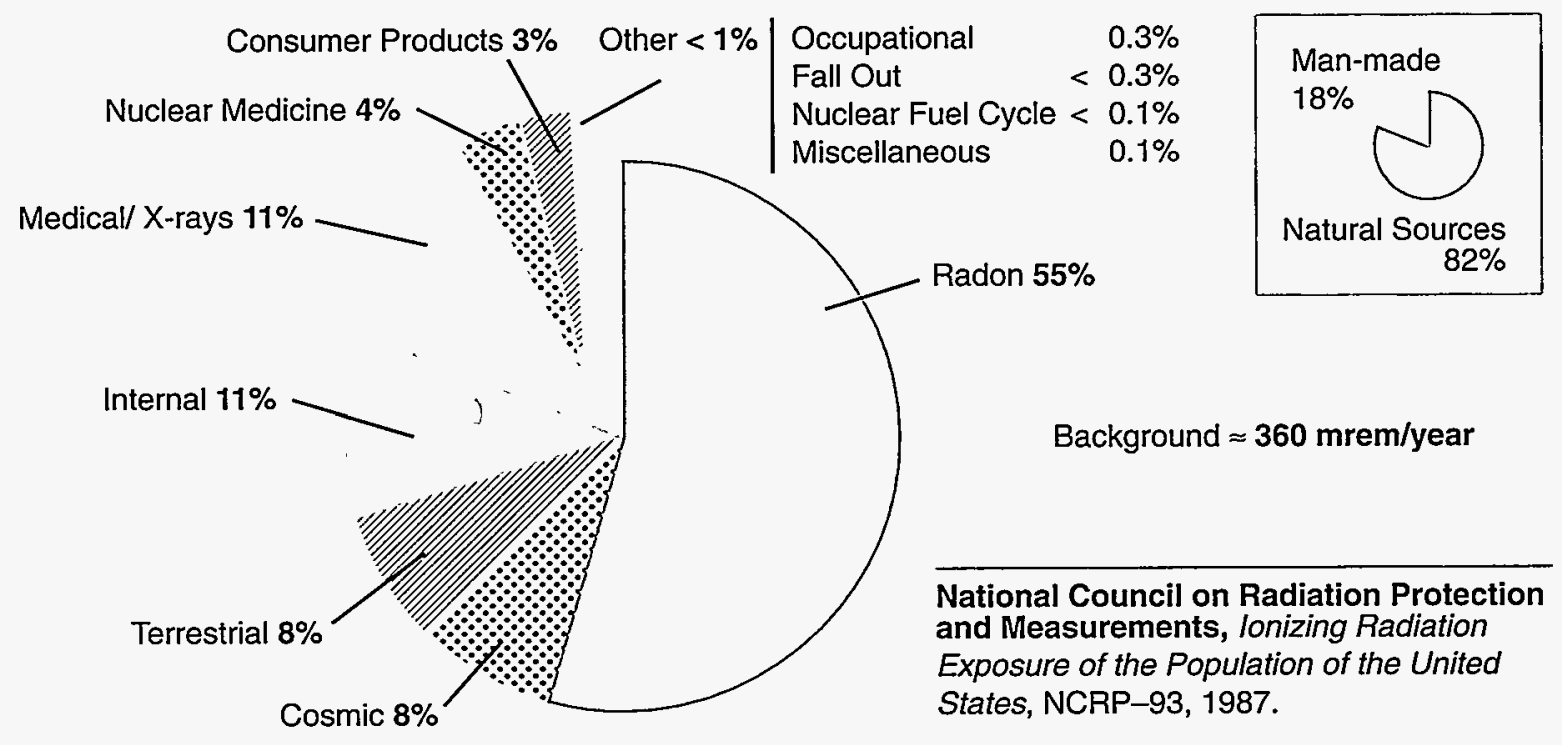


Figure 18: Breakdown of Average U.S. Radiation Exposures

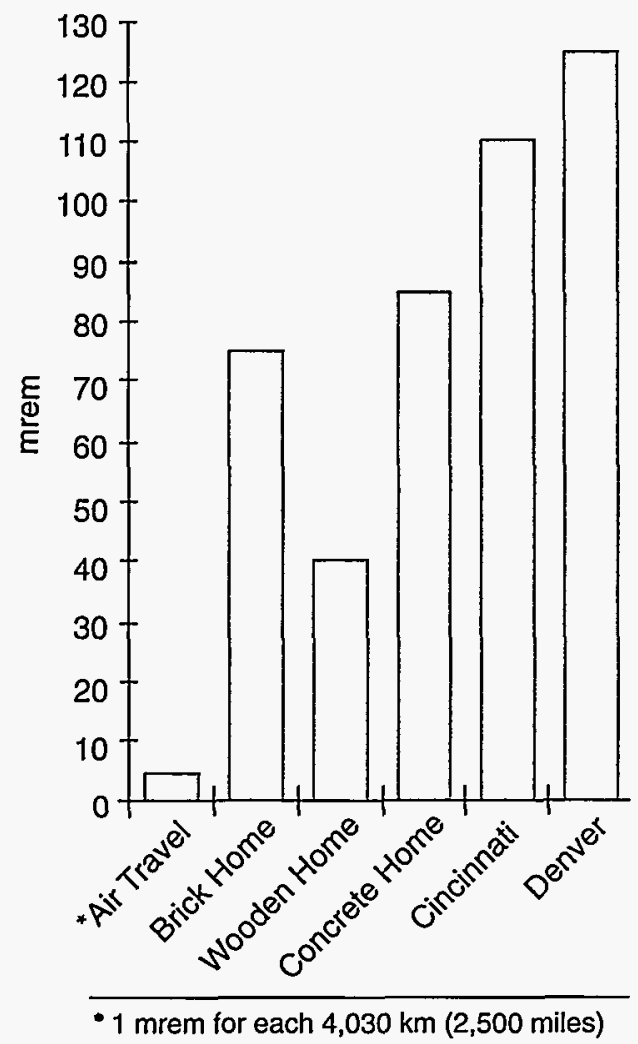

Background radiation dose will vary in different parts of the country. For example, living in the Cincinnati area will produce an annual exposure level of approximately $110 \mathrm{mrem}$, while living in Denver will produce an annual exposure level of approximately $125 \mathrm{mrem}$. This difference can be attributed to soil composition and distance above sea level. Another factor which affects annual radiation dose is the type of building material used in homes. Figure 18 shows that the annual dose received from living in a brick or concrete house is about two times greater than from living in a wood frame house. Also shown in Figure 18 is that a single round trip flight from Cincinnati to London (or the equivalent) produces an exposure of approximately 4 mrem. ${ }^{16}$ In comparison, the dose received at the site's fenceline from an entire year is approximately $1.0 \mathrm{mrem}$, excluding radon.

One way to measure how much radiation we are exposed to is to complete a personal radiation dose worksheet, like the one on the next page. The next section provides information on the effects of low-level radiation, whether it is naturally occurring or originates from a facility like the Fernald site.

\section{Effects of Radiation}

The effects of radiation on humans are divided into two categories, somatic and genetic. Somatic effects develop in the directly exposed individual, including a developing fetus. Genetic effects are those that are observed in the offspring of the exposed person.

Because we are constantly exposed to both natural and man-made sources of radiation, and because the body has the capacity to repair damage from low levels of radiation, it is extremely difficult to determine the effects from low-level radiation. This section explains why this is true and how somatic and genetic effects may occur. 
Personal Background Radiation Dose Worksheet*

Source of Radiation

Annual Dose (mrem)

\begin{tabular}{|c|c|c|}
\hline \multicolumn{3}{|l|}{ Earth and Sky } \\
\hline & Cosmic radiation at sea level & 26 \\
\hline & $\begin{array}{l}\text { Cosmic radiation above sea level } \\
\text { Add } 1 \text { mrem for every } 100 \text { feet above sea level } \\
\text { (Cincinnati is approximately } 600 \text { feet above sea level.) }\end{array}$ & \\
\hline & $\begin{array}{l}\text { Jet plane travel/high altitude exposure to cosmic radiation } \\
\text { Add } 1 \mathrm{mrem} \text { for every } 2,500 \text { miles flown }\end{array}$ & \\
\hline & Terrestrial Radiation & 28 \\
\hline & Radon (background) & 200 \\
\hline & Nuclear testing fallout & 5 \\
\hline Your Body & & 40 \\
\hline Television Viewing & $\begin{array}{l}\text { Add } 0.15 \text { mrem for every hour of viewing per day } \\
\text { (For example, if you watched an average of } 4 \text { hours of TV a day } \\
\text { in } 1993 \text {, add } 0.6 \text { mrem.) }\end{array}$ & \\
\hline \multicolumn{3}{|c|}{ Medical X-ray and Radiopharmaceutical Diagnosis } \\
\hline \multicolumn{3}{|c|}{ Add 10 mrem for each chest $X$-ray } \\
\hline \multicolumn{3}{|c|}{ Add 500 mrem for lower gastrointestinal-tract $X$-ray procedure } \\
\hline \multicolumn{3}{|c|}{ Add 300 mrem for each radiopharmaceutical examination } \\
\hline Total & & \\
\hline
\end{tabular}

* The information is drawn from two major sources:

- BEIR Report-III-National Academy of Sciences, Committee on Biological Effects of lonizing Radiations,

"The Effects on Populations of Exposure to Low Levels of lonizing Radiation," National Academy

of Sciences, Washington. DC, 1980, and

- National Council on Radiation Protection and Measurements Report No. 93, 1987.

\section{Somatic Effects}

Continuous exposure to low levels of radiation can produce gradual somatic changes over extended time. For example, someone may develop cancer from man-made radiation, background radiation, or some other source not related to radiation. Because all illnesses caused by low-level radiation can also be caused by other factors, it is presently impossible to determine individual health effects of low-level radiation. However, there are a few groups of people under medical observation because they have been exposed to higher levels of radiation. These include the survivors of Hiroshima and Nagasaki, uranium miners in the United States and eastern Europe, a group of workers who used paint containing radium, early users of X-ray machines, some DOE employees working in the defense facilities, and people suffering from illnesses where radioactive material was used for treatment. 
Even after studying the health effects of radiation on these groups of people, scientists are still not able to determine with certainty how much cancer, if any, may have been caused by low-level radiation. Those individuals exposed to high levels of radiation are at greater risk. We know this because at these higher radiation doses, we see that the number of radiation effects increases as the level of radiation dose increases.

A whole-body dose of 1,000 rem of radiation delivered instantaneously will probably kill a person. A dose of 600 to 1,000 rem causes severe sickness, but there is some chance for recovery. A dose of 200 to 600 rem causes some sickness with a very good chance for recovery. A dose of 100 to 200 rem could possibly cause some vomiting, but probably no demonstrable long-lasting effects. ${ }^{17}$

Significant clinical symptoms of radiation probably will not be seen in individuals who have been exposed to less than $100 \mathrm{rem} .{ }^{18}$ Most scientists believe that there are no directly observable short-term radiation effects on human beings exposed to less than 10 rem because the biological damage created by this level of radiation is too small to result in near-term clinical symptoms.

Estimates on the value of the threshold level for radiation effects, if such a level exists, vary significantly. As mentioned above, some scientists believe it could be as high as $10 \mathrm{rem} .{ }^{17}$ Others insist there is no threshold level below which radiation exposure is safe. ${ }^{19}$ They feel there is always a direct relation between the amount of radiation to which people are exposed and the number of related radiation effects.

Somatic effects have been documented only at high radiation levels. These include clouding (cataract formation) of the lens of the eye, lowered fertility rate, and a reduced number of white cells in the blood. Problems caused by radiation seen in the development of the embryo result from large doses, not the low levels characteristic of background radiation. Therefore, the most likely somatic effect of low-level radiation is believed to be a small increased risk of cancer. ${ }^{15}$

\section{Genetic Effects}

A single ionizing event has the potential to cause a genetic effect. To understand this, it is helpful to look at the structure of a human cell.

Human cells normally contain 46 chromosomes - 23 transmitted from the mother and 23 from the father. These 46 chromosomes contain about 10,000 genes which are passed to the offspring and determine many physical and psychological characteristics of the individual.

Radiation can cause physical changes or mutations in these genes. Chromosome fibers can break and rearrange, causing interference with the normal cell division 
of chromosomes by affecting their number and structure. A cell can rejoin the ends of a broken chromosome, but if there are two breaks close enough together in space and time, the broken ends from one break may join incorrectly with those from another. This can cause translocations, inversions, rings, and other types of structural rearrangement. ${ }^{15}$ Radiation is not the only cause of such changes. Spontaneous mutations and chemically induced mutations have been observed.

The mutated genes from one parent can be passed to offspring. They typically have no effect on the offspring as long as the genes from the other parent are not mutated in the same way. However, the genes stay in the chromosomes of the offspring and are passed on to following generations. In reproducing, if both parents pass similar mutated genes to the offspring, the mutation would become present in the characteristics of the offspring. ${ }^{17}$

There is no evidence that there are radiation levels below which chromosomes are not affected; however, genetic effects of radiation have never been clearly demonstrated to occur in people. ${ }^{20,21}$

\section{Health Hazards at the Fernald Site}

Aside from radiation and its effects, there are other health hazards associated with the Fernald site. In order to understand these other health hazards, it is helpful to be familiar with the terminology and laws that define and regulate these hazards.

\section{Definitions of Terms}

Many terms refer to substances that are subject to regulation under one or more federal environmental laws. State laws and regulations also provide similar terminology that may be confused with the federally defined terms. Many of these terms appear to be synonymous and are easily confused.

A hazardous chemical, as defined by the Occupational Safety and Health Administration (OSHA), is any chemical which is a physical hazard or a health hazard. Physical hazards include combustible liquids, compressed gases, explosives, flammables, organic peroxides, oxidizers, pyrophorics, and reactives. A health hazard, on the other hand, is any chemical for which there is good evidence that acute or chronic health effects occur in exposed people. Among the list of hazardous chemicals are carcinogens, irritants, corrosives, neurotoxins, and agents that damage the lungs, skin, eyes, or mucous membranes.

A hazardous material, as defined by the Department of Transportation, is a substance or material in a quantity and form which may pose an unreasonable risk to health and safety or property when transported in commerce. With more than 16,000 entries, the Hazardous Materials Table includes explosives, oxidizing 
materials, corrosives, flammables, gases, poisons, radioactive substances, and agents capable of causing disease.

A hazardous substance is any substance designated under Section 311 of the Clean Water Act; any element, compound, mixture, solution, or substance designated as hazardous under Section 102 of Comphrensive Environmental Response, Compensation, and Liability Act (CERCLA); any listed or characteristic Resource Conservation and Recovery Act (RCRA) hazardous waste; any toxic or pollutant listed under Section 307 of the Clean Water Act; any hazardous air pollutant listed under Section 112 of the Clean Air Act; and any imminently hazardous chemical substance or mixture subject to Section 7 of the Toxic Substances Control Act.

A hazardous waste is a solid waste that must be treated, stored, transported, and disposed of in accordance with applicable requirements under Subtitle $\mathrm{C}$ of RCRA. Hazardous wastes may cause or significantly contribute to an increase in mortality or an increase in serious irreversible, or incapacitating reversible, illness. These kinds of wastes may also pose a substantial present or potential hazard to human health or the environment when improperly treated, stored, transported, disposed of, or otherwise managed. Hazardous wastes are either listed in the regulations promulgating RCRA or are "characteristic" wastes. "Characteristic" hazardous wastes include those that are ignitable, corrosive, reactive, or toxic. All RCRA Subtitle $C$ listed or characteristic hazardous wastes are also CERCLA hazardous substances. ${ }^{22}$

\section{Laws Regulating Health Hazards}

Some of the federal laws that regulate health hazards are discussed below. The first, $C E R C L A$, provides for the remediation of hazardous substances at National Priority List (Superfund) sites. As well, CERCLA has its own reporting and response requirements when a hazardous substance released to the environment exceeds a reportable quantity.

RCRA Subtitle $C$, as previously discussed, provides for the safe treatment and disposal of hazardous waste and regulates hazardous waste management practices for generators, transporters, and owners and operators of treatment, storage, and disposal facilities.

Section 6 of TSCA authorizes USEPA to initiate civil actions regarding hazardous chemical substances or mixtures which present an imminent and unreasonable risk of serious or widespread injury to health or the environment. There is no "list" of imminently hazardous chemical substances or mixtures, but USEPA currently regulates Polychlorinated Biphenyls (PCB), fully halogenated chlorofluoroalkanes, asbestos, and hexavalent chromium under Section 6 of TSCA. 
The Clean Air Act established the National Emission Standards for Hazardous Air Pollutants (NESHAP). There are many hazardous air pollutants, including asbestos, benzene, beryllium, coke oven emissions, inorganic arsenic, mercury, radionuclides, and vinyl chloride.

\section{Types of Health Threats}

There are many types of potential health threats (aside from the radioactive risks already discussed) related to the hazardous substances at the site. They should all be addressed and understood by both area residents and onsite workers so the substances will be handled properly and safely or avoided whenever possible. Carcinogens, corrosives, explosives, flammables, irritants, and poisons/toxins are all potentially harmful.

Carcinogens are substances that have the potential to cause cancer. A common carcinogen at the Fernald site is asbestos. When asbestos particles are inhaled into the lungs, they may damage the alveoli (the air sacs lining the lungs). This damage makes the lungs more susceptible to cancer, especially in smokers.

Corrosives are chemicals that cause a substance to wear away or deteriorate. Many common chemicals are potentially corrosive. For example, vapors from ammonia may be corrosive to the eyes, respiratory system, and other moist tissues. Blindness may result from a large exposure to these vapors.

Explosions can occur in many situations. If an unstable solid or liquid changes suddenly into a quickly expanding gas, especially in a tightly closed container, an explosion can occur. Rapid nuclear fission may also cause a substance to explode. During these explosions, energy is released, often in the form of heat and sometimes radiation. This energy release may cause injury resulting from the impact of debris or burns to exposed skin.

Flammable materials are any materials which can be easily set on fire and burn readily. Paints, gases, and fuels are common flammable materials at the site. Hydrogen, for example, is a very flammable gas. An obvious health hazard associated with flammable material is the potential for burns.

An irritant is a substance which causes an organ or any part of the body to become inflamed or sore. 1,1,1-trichloroethane, a common solvent used at the site, can be an irritant to the skin and the eyes upon contact.

Poisons and toxins are substances that may cause illness or death when ingested or absorbed into the body. Nearly all chemicals have the potential to become poisonous or toxic when used improperly or in excessive amounts. A toxin that destroys nerves or nervous tissue is called a neurotoxin. 
The next chapter, "Environmental Compliance Summary," presents the Fernald site's status with several environmental regulations. The environmental monitoring data are presented in Chapters Four, Five, and Six. Chapter Seven presents a discussion of the estimated radiation doses to which the people near the site might be exposed and how these results were calculated. Then, Chapter Eight discusses the Radon Monitoring Program and presents the 1995 radon monitoring and dose results. 


\section{ENVIRONMENTAL COMPLIANCE SUMMARY}

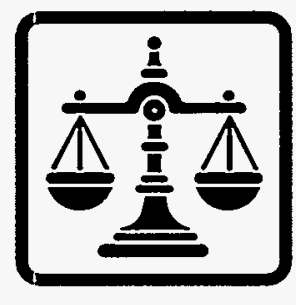




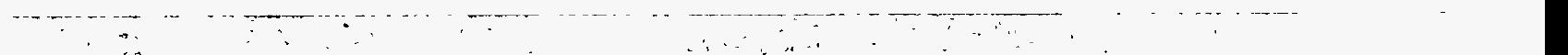




\section{Environmental Compliance Summary}

The Fernald site (a Superfund site planned for total remediation) must comply with environmental requirements established by a number of agencies governing daily operations at the site. These requirements fall into four general categories:

- Requirements imposed by federal statutes and regulations;

- Requirements imposed by state and local statutes and regulations;

- Requirements imposed by DOE Orders and directives; and

- Site-specific requirements imposed through agreements with regulatory agencies.

Because these requirements are initiated by several different sources, enforcement likewise falls under several federal, state, and local agencies. The United States Environmental Protection Agency (USEPA) develops, promulgates, and enforces environmental protection regulations and technologybased standards as directed by statutes passed by Congress. USEPA Region 5 implements the Comprehensive Environmental Response, Compensation, and Liability Act (CERCLA) process, with the active participation of the State of Ohio EPA (OEPA). For some programs, USEPA has authorized the State of Ohio to enforce its regulatory program in lieu of the federal program. For these programs, Ohio promulgates state regulations which must be at least as stringent as the federal requirements and may be more stringent than the federal requirements. OEPA has authorized programs that issue permits, review compliance reports, inspect facilities and operations, and oversee compliance with the Resource Conservation and Recovery Act (RCRA), the Clean Air Act (CAA), the Clean Water Act (CWA), and the Safe Drinking Water Act. The site is also subject to several legal agreements with USEPA Region 5 and/or OEPA. DOE Headquarters issues directives to its field offices and conducts compliance audits. In addition, the Fernald site conducts internal audits.

This chapter summarizes the Fernald site's progress toward achieving full compliance with all environmental regulations. It is divided into two main sections - "Compliance Status" and "Major Accomplishments and Issues." Additionally, the status of several environmental permits is discussed within the appropriate regulatory categories. This summary covers calendar year 1995 as required by DOE reporting requirements. 


\section{Compliance Status}

This section presents a summary of the Fernald site's compliance status with respect to federal and state environmental regulations.

\section{Comprehensive Environmental Response, Compensation, and Liability Act}

The Fernald site is on the National Priorities List (NPL), a list of sites requiring environmental cleanup under CERCLA, as amended. Consistent with the requirements of CERCLA Section 120, a Consent Agreement was signed by DOE and USEPA in April 1990 which outlined activities and schedules to be performed in order to remedy the site conditions. This agreement was amended in September 1991. Collectively, the Consent Agreement and the Amended Consent Agreement, jointly referred to as the ACA, divided the Fernald site into operable units (OUs) to more effectively manage the study portions (defined on page 49 of this chapter) of the CERCLA remedial response process. The OUs were defined as presented in the following table, based on their location or the potential for similar technologies to be used in site remediation.

\begin{tabular}{|c|c|c|}
\hline OU & Descriptive Title & Description \\
\hline OU1 & Waste Pits Area & $\begin{array}{l}\text { - Waste Pits } 1-6 \\
\text { - Clearwell } \\
\text { - Burn Pit } \\
\text { Berms, liners, and soil within the OU boundary }\end{array}$ \\
\hline OU2 & Other Waste Units & $\begin{array}{l}\text { - Solid Waste Landfill } \\
\text { - Inactive Flyash Pile } \\
\text { - Active Flyash Pile (now inactive) } \\
\text { - North and South Lime Sludge Ponds } \\
\text { - Other south field disposal areas } \\
\text { Berms, liners and soil within the OU boundary }\end{array}$ \\
\hline OU3 & $\begin{array}{l}\text { Former } \\
\text { Production Area }\end{array}$ & $\begin{array}{l}\text { Production area and production-associated facilities and equipment } \\
\text { (includes all above- and below-grade improvements) including, but not } \\
\text { limited to: } \\
\text { - all structures, equipment, utilities, effluent lines, K- } 65 \text { transfer line } \\
\text { - wastewater treatment facilities } \\
\text { - fire training facilities } \\
\text { - coal pile } \\
\text { - scrap metals piles } \\
\text { - drums, tanks, solid waste, waste, product, feedstocks, thorium }\end{array}$ \\
\hline OU4 & Silos $1-4$ & $\begin{array}{l}\text { - Silos } 1 \text { and } 2 \text { (containing K-65 residues) } \\
\text { - Silo } 3 \text { (containing cold metal oxides) } \\
\text { - Silo } 4 \text { (empty and never used) } \\
\text { - Decant tank system } \\
\text { - Berms and soil within the OU boundary }\end{array}$ \\
\hline OU5 & Environmental Media & $\begin{array}{l}\text { - Groundwater } \\
\text { - Surface water and sediments } \\
\text { - Soil not included in the definitions of OUs } 1-4\end{array}$ \\
\hline $\mathrm{CSOU}$ & $\begin{array}{l}\text { Comprehensive } \\
\text { Statewide } \\
\text { Operable Unit }\end{array}$ & $\begin{array}{l}\text { A comprehensive unit encompassing OUs } 1-5 \text { to ensure that actions } \\
\text { taken under the individual OUs are protective of human health and the } \\
\text { environment on a site-wide basis. This is not a specific site area. }\end{array}$ \\
\hline
\end{tabular}


The ACA provided schedules for the completion of the ongoing remedial investigation (RI) and feasibility study (FS) activities for each operable unit; initiated removal actions, which are tasks undertaken to abate immediate threats to the environment and public health; and provided a mechanism for the site to add additional removal actions on a yearly basis. The following table presents explicit 1995 completion dates from the ACA for the various activities - RI, baseline risk assessment (BRA), FS, and proposed plan (PP) - which culminate in the selection of CERCLA remedial action in the record of decision (ROD).

\begin{tabular}{ll}
\hline OU & ACA-explicit 1995 Deadline CERCLA Remedial Response Activities \\
\hline OU1 & - No ACA-explicit deadlines for CERCLA remedial response activities during 1995. \\
OU2 & - Draft OU2 ROD; submitted to USEPA February 3. (Original ACA-explicit submittal date was \\
& January 5; however, with USEPA concurrence, the date was changed to February 4 to accommo- \\
date an extended public comment period.) & - Draft OU3 RI/FS/PP; submitted to USEPA September 11. \\
OU3 & - No ACA-explicit deadlines for CERCLA remedial response activities during 1995. \\
OU4 & Draft OU5 ROD; submitted to USEPA August 2. (Original ACA-explicit submittal date was July \\
OU5 & 3; however, with USEPA concurrence, the date was changed to August 2 to accommodate an \\
& extended public comment period.) \\
CSOU & No ACA-explicit deadlines for CERCLA remedial response activities during 1995. \\
\hline
\end{tabular}

Figure 19 presents an overview of how the various activities mentioned above, and subsequent activities, fit together to lead to CERCLA remedial action for OUs 1-5.

In very broad terms, the remedial response process for remediating sites under CERCLA consists of three general phases. The first phase is site characterization. This phase determines what contaminants are present and at what levels, and also evaluates the potential impacts of those contaminants on human health and the environment. Activities associated with this phase are the RI and the BRA.

The second phase is remedy selection. This phase develops and evaluates different cleanup alternatives and, with appropriate public involvement, selects a remedy. Activities associated with this phase are the FS, PP, and public comment period, which culminate in the selection of CERCLA remedial action in the ROD and its attached responsiveness summary (RS).

The first and second phases discussed above are commonly referred to as the "study" portions of the process. The final phase is actual site cleanup.

As shown in Figure 19, the study phases of the process at Fernald are essentially complete for the entire site and actual cleanup has started. Initial characterization of the entire Fernald site began in 1986. In 1991, a segmented RI and FS began, which completes site characterization and supports remedy selection for all five study areas (operable units) targeted for remediation; this process is substantially 
complete. By the end of 1995, there were signed Records of Decision, which document remedy selection, for four of the five operable units. The ROD for OU5 was submitted in August 1995 with approval expected in early 1996. All selected remedies have been approved by USEPA with the concurrence of OEPA. It should be noted that a Record of Design for Interim Remedial Action (IROD) was signed by DOE and USEPA in July 1994 in order to provide for quicker progress in the decontamination and dismantlement of buildings and support structures, thereby lessening their potential immediate threat to the environment. The IROD will be followed by a Final OU3 ROD, scheduled for submittal in July of 1996, which will address treatment and disposition of the materials resulting from the performance of the interim remedial action.

The selected cleanup options primarily use technologies and process options that have been successfully implemented at CERCLA sites throughout the country. For the one innovative technology selected (which is vitrification, the OU4 selected remedy), extensive testing at Fernald has proven its applicability to the site. Accordingly, there do not appear to be any significant technical issues that would prevent timely implementation of the selected and proposed remedies at the site. Fernald has begun implementation of its cleanup remedies; indeed, construction has begun on a vitrification pilot plant, which will turn radioactive sludges into a glass-like form. CERCLA requires that remedial action for a particular OU begin within 15 months of the date that its ROD is signed, so actual cleanup activities will be underway for the entire site in a matter of months. In addition, 32 shortterm removal actions, designed to eliminate or control contamination sources prior to final cleanup, have been completed or are now in progress at Fernald.

\section{Superfund Amendments and Reauthorization Act}

The Superfund Amendments and Reauthorization Act of 1986 (SARA) amended CERCLA and was enacted, in part, to clarify and expand CERCLA ("Superfund") requirements. The SARA Title III, Section 312 Emergency and Hazardous Chemical Inventory Report for 1995 was completed and submitted to OEPA and other local emergency planning/response organizations in February 1995. The report lists the amount and location of hazardous substances stored or used in amounts greater than the minimum reporting threshold during any one given 24 hour period.

The SARA Title III, Section 313 Toxic Chemical Release Inventory Report was submitted to OEPA and USEPA by July 1, 1995. The report is required for any toxic chemical or chemical category (as listed in the appropriate Federal Regulation), that is manufactured, processed, or otherwise used at a facility in quantities greater than the respective reporting threshold during a period of one calendar year. The Toxic Chemical Release Inventory Report lists routine and accidental releases, as well as information about the activities, uses, and waste for each reported toxic chemical. The report also includes source reduction and recycling information as required by the Pollution Prevention Act of 1990. 


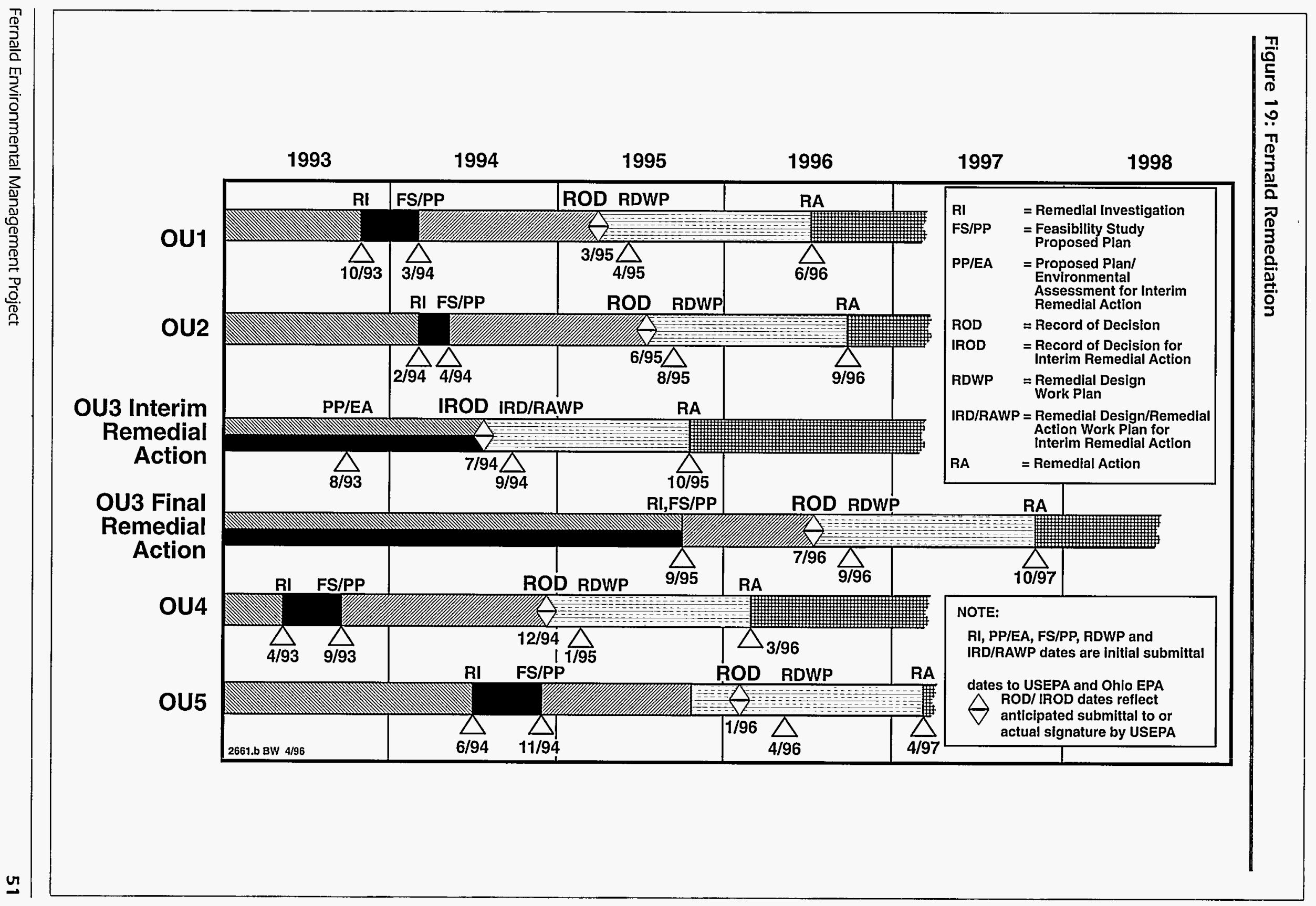


For any offsite release meeting or exceeding the reportable quantity (RQ), SARA Title III, Section 304 requires immediate notifications to local emergency planning committees (LEPC) and the state emergency response commission (SERC). All releases occurring at Fernald are evaluated to ensure that proper notifications are made in accordance with SARA Section 304. In addition to SARA, releases are also evaluated for notification under CERCLA Section 103, RCRA, the Toxic Substances Control Act (TSCA), CAA, CWA, Ohio environmental laws and regulations, and the Ohio Fire Code. Department of Transportation regulations are also followed. Depending on the respective requirements, notifications may also be made to the National Response Center (NRC) and to the appropriate federal, state, and local regulatory entities.

In 1995, one release was reported at Fernald. On May 24, 1995, one (1) gallon of an antifreeze and water solution containing approximately $4.5 \mathrm{lbs}(2.043 \mathrm{~kg})$ of ethylene glycol was released from an employee's vehicle onto the parking lot adjacent to the southwest trailer complex. At the time of this release, the RQ for ethylene glycol was the default one (1) pound under CERCLA; therefore, notification of the release was made to the NRC. This release was not reportable under SARA because it did not leave the site.

\section{Resource Conservation and Recovery Act}

The Resource Conservation and Recovery Act (RCRA) as amended regulates treatment, storage, and disposal of hazardous waste. OEPA has been authorized to enforce its hazardous waste regulations in lieu of the federal RCRA program.

Past operations and ongoing cleanup activities generate both hazardous wastes and mixed wastes (containing hazardous and radioactive components). Because there are a limited number of facilities in the United States that can treat or dispose of mixed waste, most of the mixed waste has been stored onsite. In 1995, the Fernald site initiated and completed a number of projects to treat mixed waste. These projects reduced the total quantity of stored mixed waste by $48 \%$ as compared to 1994 and included the following activities:

- Completed treatment by precipitation and neutralization of 200,000 gallons of uranyl nitrate hexahydrate stored in 19 tanks, and initiated treatment of 30,000 gallons of nitric acid;

- Stabilized 6,500 gallons of thorium nitrate stored in Tank T-2;

- Neutralized approximately 6,000 gallons of hydrofluoric acid as part of a RCRA closure of a Hazardous Waste Management Unit;

- Treated 391 containers of mixed waste using a cement-based stabilization process as part of the Mixed Waste Stabilization Project. This project is scheduled to treat approximately 1,850 containers of mixed waste by early 1996;

- Shipped 43,460 gallons of liquid mixed waste to the K-25 Toxic Substances Control Act (TSCA) Incinerator in Oak Ridge, Tennessee for treatment; and

- Shipped $131,468 \mathrm{lbs}(59,686 \mathrm{~kg})$ of mixed low-level waste to Envirocare of Utah in Clive, Utah for disposal. 
In addition to being subject to state and federal regulation, hazardous waste management is subject to the 1988 Consent Decree and its Stipulated Amendment (SACD) entered into between the State of Ohio and DOE. In accordance with the SACD and RCRA, the site completed or initiated several activities relating to mixed waste storage and treatment during 1995. These included submittal of the RCRA Annual Report and submittal of revisions to the RCRA Part A/B Permit Application. The renovation of Plant 1 Pad was completed in February 1995. This activity was conducted as a CERCLA Removal Action (RA No. 7) and included the addition of three tension support structures to provide covered storage for mixed and low-level waste. The final version of the Federal Facility Compliance Act (FFC Act) Site Treatment Plan (STP) was also approved and the implementing Order issued by OEPA as discussed in the FFC Act section which follows.

\section{Federal Facility Compliance Act}

The Fernald site stores mixed wastes that are subject to the RCRA Land Disposal Restrictions (LDR). These restrictions currently prohibit the storage of certain hazardous waste streams unless an extension is approved by USEPA or the appropriate state regulatory agency (i.e., OEPA). Due to the lack of available treatment and disposal facilities for mixed wastes, DOE facilities, including the Fernald site, are continuing to store this mixed waste.

The Federal Facility Compliance Act (FFC Act) of October 1992, an amendment to RCRA, provided DOE with an exemption from enforcement under the LDR storage prohibition until October 6,1995 , provided the mixed waste in question was managed in accordance with all other RCRA requirements. The time period stated in the amendment was subject to extension as long as DOE submitted and obtained approval of a plan for developing treatment capacity for those mixed wastes under an enforceable order with USEPA or OEPA no later than October 6, 1995. The site submitted a Draft Site Treatment Plan (DSTP) to OEPA in August 1994 for review and comment, presenting the preferred options and technologies for treating mixed waste currently in inventory at the site. After a public review and comment period, the Proposed Site Treatment Plan (PSTP) was submitted to OEPA on March 31, 1995. Another 90-day public comment period for stakeholder review and input on the PSTP was opened by OEPA, extending from April 6 to July 6, 1995. Responses to OEPA comments on the PSTP were incorporated in the Amended Proposed Site Treatment Plan and the plan was submitted to OEPA October 3, 1995. The OEPA issued Final Findings \& Orders of the Director (DF\&O) approving the Site Treatment Plan (STP) on October 4, 1995.

The plans developed to implement the DF\&O on the STP are incorporated in Removal Action No. 9, Removal of Waste Inventories. Detailed information on site activities which treated or shipped waste under RA No. 9 are provided in the tables on page 69 .

\section{Clean Air Act}

OEPA has the authority to enforce its requirements in lieu of the federal Clean Air Act (CAA), except for the enforcement of the National Emission Standards for 
Hazardous Air Pollutants (NESHAP) for radionuclides and radon. Most site air emission sources are regulated by OEPA as particulate, chemical, or toxic emission sources, and by USEPA as radionuclide sources.

The NESHAP standard for radionuclide air emissions from DOE facilities imposes a limit of 10 mrem per year on the effective dose equivalent (EDE) to the maximally exposed individual as a result of all emissions (with the exception of radon) from the facility in a single year. This standard also imposes requirements for continuous monitoring of certain emission sources and periodic confirmatory measurements of smaller sources. All NESHAP monitoring points at the Fernald site are in compliance with the requirements.

Because the Fernald site is a former uranium processing plant, uranium is the radioactive particulate of most concern in monitoring airborne emissions. The Fernald site estimated that airborne uranium emissions for 1995 totaled $3.5 \mathrm{~kg}$

Figure 20: Total Kilograms of Uranium to Air, $1990-1995$

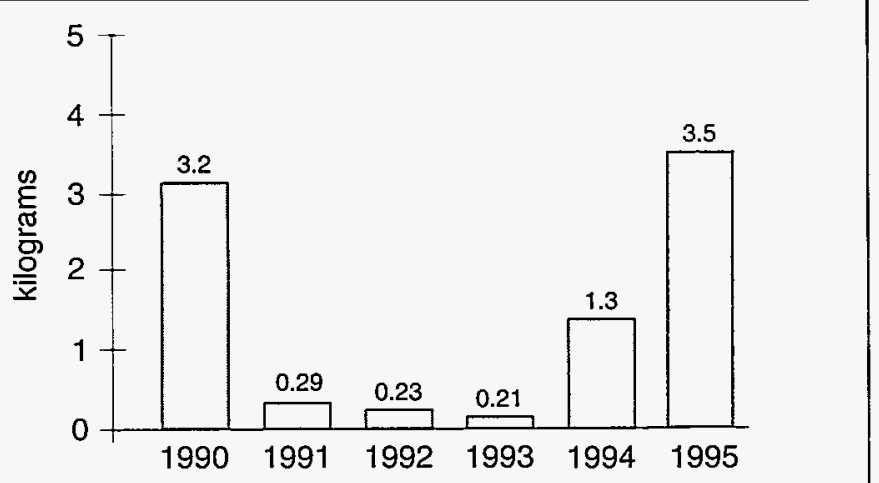

(7.7 lbs). This increase from the $1.3 \mathrm{~kg}(2.9$ lbs) estimated for 1994 is attributed primarily to increased operation of the vacuum filters in Plant 8 during 1995. Two of the three filters in Plant 8 were out of operation for the majority of 1994; however, all three filters operated throughout 1995 to support both wastewater treatment and UNH neutralization activities. The resultant 1995 dose to the maximally exposed offsite resident remains very small; at 0.19 mrem, it is only $1.9 \%$ of the NESHAP Subpart $\mathrm{H}$ limit of $10 \mathrm{mrem}$.

In 1993, the State of Ohio regulation limiting sulfur dioxide $\left(\mathrm{SO}_{2}\right)$ emissions became effective, which reduced the allowable $\mathrm{SO}_{2}$ emission level from the site's coal-fired burners (the only Clean Air Act-defined major source at Fernald) from $2.0 \mathrm{lbs}(0.91 \mathrm{~kg}) \mathrm{SO}_{2} / 10^{6} \mathrm{BTU}$ heat input to $1.3 \mathrm{lbs}(0.60 \mathrm{~kg}) \mathrm{SO}_{2} / 10^{6} \mathrm{BTU}$ heat input. The Fernald site began purchasing a low-sulfur coal in 1991 when the regulation was revised, and the site has been in compliance with the reduced limit since that time.

\section{Clean Water Act}

Under the Clean Water Act (CWA), the Fernald site is governed by National Pollutant Discharge Elimination System (NPDES) regulations which require the control of discharges of nonradioactive pollutants to Ohio waters.

\section{NPDES Effluent Regulation}

The NPDES permit issued by the State of Ohio specifies discharge and sampling locations, sampling and reporting schedules, and discharge limitations. Current monitoring locations are referenced in Figure 21 on page 56. The current permit, effective November 1, 1995, expires March 31, 1998. 
In 1995, the Fernald site complied with the discharge limits specified by the NPDES permit $98.4 \%$ of the time. Of the 2,367 monitoring results reported to OEPA during the year, only 37 were not within the discharge limits specified by the permit. Twenty-nine $\mathrm{pH}$ violations and one suspended solids violation occurred at Manhole 175; two fecal coliform violations occurred at the Sewage Treatment Plant; and four biological oxygen demand (BOD) violations as well as one nitrate-nitrogen violation occurred at the Biodenitrification/Effluent Treatment System. Greater detail concerning all these non-compliances can be found in Table 16A on page A-23 of this report. All non-compliant conditions were reported to OEPA, as required by the NPDES permit.

\section{NPDES Stormwater Regulation}

Issuance of the November 1, 1995, NPDES permit included four stormwater monitoring locations. These four monitoring locations are shown in Figure 21 as follows:

- 4003 Collecting runoff from the east and south;

- 4004 Collecting runoff from the Inactive Flyash pile;

- 4005 Collecting runoff from the western property perimeter, excluding the waste management facilities; and

- 4006 Collecting runoff from the northern property perimeter.

\section{Safe Drinking Water Act}

The Safe Drinking Water Act (SDWA) regulates generation and treatment of drinking water supplied to the public. The Fernald site drinking water system is regulated by OEPA as a non-transient, non-community public drinking water system.

During 1995, the site monitored its drinking water system and reported results for copper, lead, nitrate, and coliform bacteria, in addition to alkalinity, $\mathrm{pH}$, stability, phosphate, hardness, and chlorine residuals. All results met applicable standards.

\section{Toxic Substances Control Act}

The Toxic Substances Control Act (TSCA) regulates the manufacturing, use, storage, and disposal of toxic materials. Under TSCA, USEPA regulates polychlorinated biphenyls (PCBs) and PCB items from past operations, maintenance activities, and remediation activities at the Fernald site. Non-radiologically contaminated PCBs and PCB items are shipped to TSCA-approved commercial disposal facilities for incineration on an "as-needed basis." Radiologically contaminated PCB liquids are shipped to a TSCA permitted DOE incinerator in Oak Ridge, Tennessee.

Radiologically contaminated PCB solids have no current treatment or disposal options and will remain in storage onsite until treatment or disposal capacity is available. Options for their disposal are scheduled to be pursued in conjunction with Removal Action No. 9, Removal of Waste Inventories. Mixed waste treat- 


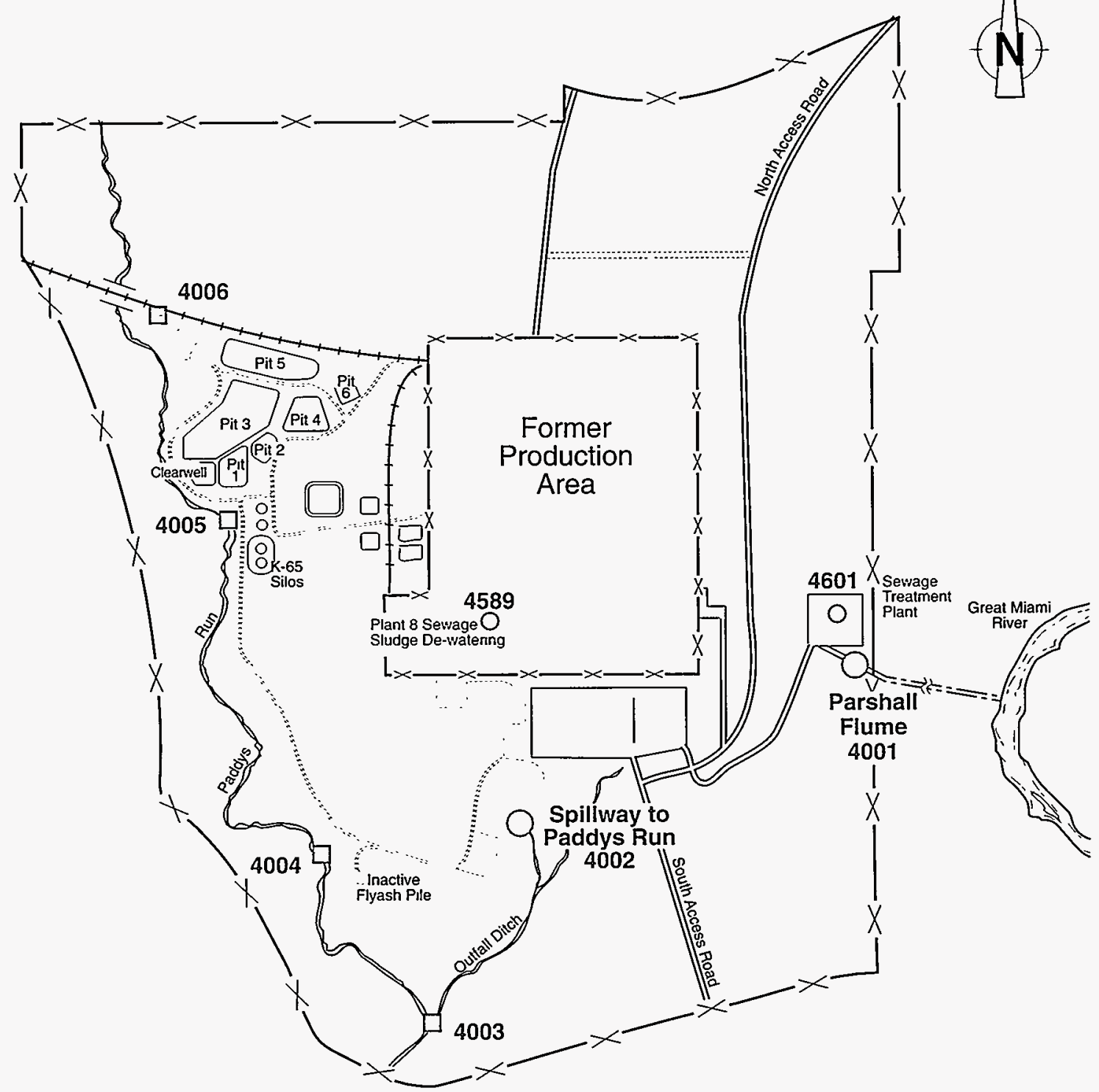

Scale of Kilometers

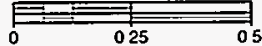

1 Kilometer $=0.62$ Mile

\section{LEGEND}

○ NPDES Internal Monitoring Location

(2) NPDES External Discharge to Ohio Waters

$\boxminus$ NPDES Stormwater Monitoring Location $>\longrightarrow>$ Plant Perimeter

$\times-\times-\times$ Former Production Area Perimeter

$\overline{=}=:$ Effluent Line to Great Miami River 
ment technology developed as part of the Fernald Site Treatment Plan pursuant to the FFC Act is being considered for treatment of radiologically contaminated PCB solids.

During 1995, the inventory of drummed radioactively contaminated PCB solids was relocated from Building 81 to Building 63 in order to make Building 81 available for thorium storage. Building 63 is a designated onsite storage area for PCBs and is in compliance with TSCA requirements.

USEPA conducted a routine TSCA compliance inspection of the Fernald site on September 21, 1994. No violations of $\mathrm{PCB}$ regulations were identified during the inspection. USEPA did not conduct an inspection of the site's TSCA program in 1995.

\section{Ohio Solid Waste Act}

The Ohio Solid Waste Act of 1988 and its subsequent revisions regulate infectious waste. The Fernald site is registered with OEPA as a large generator of infectious waste, generating more than the $23 \mathrm{~kg}$ (50 lbs) per month limit. All infectious wastes generated in the medical department are transported to a licensed treatment facility for incineration. Fernald site personnel conduct annual surveillances of the onsite medical department, the transporter, and the treatment facility to ensure that the waste is properly managed.

\section{Federal Insecticide, Fungicide, and Rodenticide Act}

Under the Federal Insecticide, Fungicide, and Rodenticide Act (FIFRA), USEPA and OEPA regulate the registration, storage, labeling, and use of pesticides (such as insecticides, herbicides, and rodenticides). Site personnel perform all insecticide and rodenticide applications onsite. Site personnel also perform herbicide applications for weed control as needed in the Administrative Support area. A subcontractor performs an annual herbicide application in various locations within the Controlled area.

All pesticide applications at the site are conducted according to federal and state regulatory requirements. As a result of the annual FIFRA program inspection conducted on September 21, 1994, USEPA Region 5 found the site to be in full compliance with the requirements mandated by FIFRA. There were no USEPA inspections of the site's FIFRA program in 1995.

\section{National Environmental Policy Act}

The National Environmental Policy Act (NEPA) requires a formal evaluation of environmental, social, economic, and cultural impacts before any action, such as a construction project, is initiated by a federal agency. DOE has published formal regulations at $10 \mathrm{CFR}$ (Code of Federal Regulations) 1021 specifically addressing the integration of NEPA with other regulatory requirements. 
NEPA evaluations for site activities continued in 1995. Major accomplishments include the completion of the Operable Unit 4 Supplemental Analysis that addressed changes in transportation modes that were not originally considered in the Operable Unit 4 Feasibility Study/Environmental Impact Statement. This document was approved by DOE-Headquarters on October 31, 1995. Also, an Environmental Assessment was written to consider options regarding disposition of the Native American remains uncovered as part of the Public Water Supply project. Native American organizations, the local community, the Ohio Historic Preservation Office, and other stakeholders have provided input into the discussion regarding disposition of the remains. The Environmental Assessment was available for review through December 18, 1995. Once finalized, this input will be factored into the decision regarding disposition of the remains.

\section{Endangered Species Act}

The Endangered Species Act (ESA) requires the protection of any federal-listed threatened or endangered species found at the site as well as any critical habitat that is essential for the species' existence. In addition, USEPA ecological guidelines direct CERCLA sites to identify any threatened species present on the property or in off-property areas affected by site activities.

The baseline ecological survey conducted by Miami University (Oxford, Ohio) in 1986-87, as well as RI/FS surveys in 1988 and consultation with the Ohio Department of Natural Resources and U.S. Fish and Wildlife Service, have established a list of federal- and state-listed threatened and endangered species that potentially or actually occur onsite or have habitat onsite. Surveys to update the information on federal- and state-listed threatened and endangered species were initiated in 1993. Moderate habitat for the cave salamander (Eurycea lucifuga - state-listed endangered), was determined to be present on the Fernald property [defined as the 1,050 acres ( 425 hectares) within the facility boundary]; however, no salamanders were found on the Fernald property. Two surveys for the Sloan's crayfish (Orconectes sloanii - state-listed threatened) were completed and showed populations of this species on the Fernald property in the northern sections of Paddys Run. Also, surveys for the Indiana bat (Myotis sodalis - federally-listed endangered) revealed suitable habitat within the riparian areas along Paddys Run, especially in the northern section of the Fernald property where the trees are older, the canopy is more complete, and water remains in the creek throughout the year.

Surveys were conducted in 1995 for the cobblestone tiger beetle (Cicindela marginipennis). This species of beetle is a federal Category Two species, meaning that it appears endangered but that there are not enough data to confirm its status. The cobblestone tiger beetle lives on gravel bars in medium-sized rivers like the Great Miami River. A survey in July, 1995 revealed six sites along the Great Miami River where the cobblestone tiger beetle is present. 


\section{CFR 1022 - Compliance with Floodplain/Wetlands Review Requirements}

DOE regulation 10 CFR 1022 specifies the requirements for a floodplain/wetland assessment where DOE is responsible for providing federally undertaken, financed, or assisted construction and improvements. It provides for compliance with Executive Orders 11988 and 11990.

Executive Order 11988, "Floodplain Management" instructs federal agencies to avoid or minimize construction activities conducted in floodplains. In 1993, modeling runs were conducted to determine the pool elevations for both the 100 - and 500 -year flood for the portion of Paddys Run adjacent to the Fernald property. Modeling results predicted a maximum discharge rate of $11,150 \mathrm{ft}^{3} / \mathrm{s}\left(15.8 \mathrm{~m}^{3} / \mathrm{s}\right)$ at the confluence of the Paddys Run and the Great Miami River at a 100-year flood flow. The 100-year flood elevation ranged from 567 feet $(172 \mathrm{~m})$ mean sea level at the Fernald property's northern boundary to 542 feet $(164 \mathrm{~m})$ mean sea level at the southern edge of the property. Based upon the pool elevations predicted by the model, the 100-year and 500-year flood flow would be retained within the banks of Paddys Run.

Executive Order 11990, "Protection of Wetlands" is a directive requiring federal agencies to institute programs to identify and protect wetlands. A wetlands delineation of the Fernald property was conducted in December 1992 and approved by the U.S. Army Corps of Engineers in August 1993. A total of 36 acres [ 15 hectares (ha)] of freshwater wetlands were delineated on the Fernald property. An updated delineation will be conducted within approximately five years of the original survey.

Floodplain/wetland assessments were conducted in 1995 in support of the OU5 FS, the Pilot Plant Drainage Ditch Project, and Removal Action No. 30 (Seepage Control at the South Field and Inactive Flyash Pile).

\section{Executive Order 12898, "Federal Actions to Address Environmental Justice in Minority and/or Low-income Populations"}

Executive Order 12898 was signed by President Clinton on February 11, 1994, and requires federal agencies to focus on the planning and enforcement of specific actions designed to promote environmental equality in minority and/or low-income communities. Secretary O'Leary's memorandum dated April 14, 1994 states that implementation of Executive Order 12898 is a priority at the U.S. Department of Energy and requires prompt support from DOE field offices. The requirements of the Executive Order 12898 are factored into the decision making process for projects carried out at the Fernald site. The National Environmental Policy Act (NEPA) process is the primary mechanism for factoring Environmental Justice issues into the planning of site activities. NEPA evaluations will consider as part of the evaluation of potential environmental impacts, any issues that may affect minority and/or low-income populations. 


\section{National Historic Preservation Act}

The Fernald site is found within an area rich in historic and prehistoric cultural resources. Protection of these resources is mandated through several laws and regulations, including the National Historic Preservation Act. In 1995, several activities were conducted to avoid and address impacts to cultural resources.

On March 24, 1994, the Ohio Historic Preservation Office commented that the Fernald property was eligible for listing on the National Register of Historic Places. DOE concurred and entered into negotiations with the Ohio Historic Preservation Office and the U.S. Advisory Council on Historic Preservation. These parties worked to develop an approach to document the buildings that will be demolished as part of remedial activities. A draft Programmatic Agreement was written that outlines the mitigation requirements agreed upon by the Ohio Historic Preservation Office and the U.S. Advisory Council on Historic Preservation. The final draft was approved by DOE-FN and the Ohio Historic Preservation Office on November 16, 1995 and was forwarded to the Advisory Council on Historic Preservation for final approval.

An archeological survey for the Public Water Supply Project - the installation of water pipelines along approximately 14 miles $(23 \mathrm{~km})$ of state and county roadways in Hamilton and Butler counties - was conducted and revealed a number of significant prehistoric artifacts, including Native American human remains. Because impacts to the human remains could not be avoided, the removal of the burials was agreed to by the Ohio Historic Preservation Office. These agreements were recorded in a Memorandum of Agreement between DOE and the Ohio Historic Preservation Office. Other interested parties, such as the Cincinnati Museum of Natural History, were consulted as well. In accordance with the Native American Graves Protection and Repatriation Act, federally-recognized Native American organizations were contacted and asked to provide input regarding excavation, research, and reburial procedures. As discussed in the NEPA compliance section, an Environmental Assessment was prepared to provide an opportunity for all stakeholders to comment regarding disposition of the remains. The Miami Tribe of Oklahoma has filed a claim for possession of the remains under the Native American Graves Protection and Repatriation Act. Negotiations continue with the Miami Tribe, other Native American organizations, and the Ohio Historic Preservation Office regarding disposition of the remains.

Additional archeological surveys were conducted in several locations on the Fernald property for various projects, including the South Field 9 Well Extraction System and the Operable Unit 2 Alternate Borrow Area. Several prehistoric and historic sites were discovered as a result of these surveys. Any potential for impacts to these sites will be addressed through consultation with the Ohio Historic Preservation Office. 


\section{Natural Resource Trusteeship}

CERCLA, Executive Order 12580, and the National Oil and Hazardous Substances Pollution Contingency Plan (NCP, 40 CFR Part 300), require that DOE act as a Trustee for natural resources at its federal facilities. These documents also appoint other federal departments, such as the Department of the Interior (DOI), as well as representatives of state government and Native American tribes, as Trustees for natural resources. The Trustee's role is to act as guardian for natural resources at the Fernald site (that is, on or off the Fernald property).

DOE initiated contact with the Fernald Natural Resource Trustees in 1993. The Trustees — who include DOE, DOI and OEPA — are currently meeting monthly to discuss potential impacts to natural resources and coordinate Trustee activities. The Trustees tentatively agreed to focus on a streamlined method for assessing natural resource impacts and restoration at the site, as an alternative to conducting a formal Natural Resource Damage Assessment. Participants in the Trustee discussions include: DOI, U.S. Fish \& Wildlife Service, OEPA, Ohio Attorney General's Office, DOE and its contractor, and USEPA.

\section{Major Accomplishments and Issues}

This section presents significant compliance-related accomplishments and issues for 1995 .

\section{Comprehensive Environmental Response, Compensation, and Liability Act}

This section presents significant CERCLA response action accomplishments and issues for 1995. The reader is encouraged to access the numerous documents described below, the administrative record for the site, the periodically issued OUspecific Fernald Progress Reports, and the Fernald Project Cleanup Report, all of which are available at the Fernald Public Environmental Information Center (PEIC).

As discussed previously, all cleanup at Fernald is mandated by CERCLA and the ACA, which specifies the schedule of activities the DOE must perform, and the dates by which they must be performed. The USEPA has approved all documentation and decisions to date. OEPA, which has been actively participating, also has concurred with the documentation and decisions produced to date. The length of time for remediation is specified in the Records of Decision; deliverable dates for design submittals appear in the Remedial Design Work Plans for the individual OUs. Neither USEPA nor OEPA have identified any significant technical issues that would prevent timely implementation of the selected and proposed remedies at the site. The regulators agree that the most significant constraint is related to the extent to which the cleanup efforts are funded. 


\section{OU1 Record of Decision Signed in March 1995}

After receipt of USEPA and OEPA comments on the Proposed Draft OU1 ROD, it was revised to Proposed Final status, submitted to USEPA for OEPA concurrence, and signed by USEPA on March 1, 1995. The selected remedial action, as presented in the OU1 ROD, is the excavation of Waste Pit contents, processing and treatment of the waste by thermal drying (as necessary to remove free water), and offsite disposal at a permitted commercial disposal facility.

The Draft OU1 Remedial Design Work Plan (RDWP) presents activities required to develop the final construction plans, specifications, and procurement documents for the implementation of the OU1 selected remedy. It was submitted to USEPA on April 26, 1995. Four comments were received from OEPA on May 30. On June 21, 1995, DOE received notification from USEPA that the OU1 RDWP had been approved without comment.

The first of the design deliverables identified in the OU1 RDWP, the Operable Unit 1 Remedial Design Preliminary Design Packages I and II, were submitted to USEPA and OEPA on October 24, 1995 for their review. These packages contain seven elements identified in the RDWP: the Plant Facilities Design Criteria document, Plant Facilities Engineering Description, Equipment Specifications, Site Improvement Plan, Construction Schedule, Excavation Plan, and Transportation and Disposal Plan.

A contract for design of upgrades to three railroad trestles within 10 miles of the site was awarded to CSX on November 17, 1995. These upgrades are needed to support rail shipments of wastes from remediation of the waste pits to an offsite facility for disposal.

\section{Dewatering Excavation Evaluation Program (DEEP)}

This OU1 short-term field program is aimed at determining the best technique to excavate the waste pit material to facilitate design and implementation of the ROD-selected remedial action for OU1. Field work for DEEP was divided into four phases:

- Phase I - taking samples via borings to obtain data on the engineering properties of the wastes in the pits, and soils in the area - completed in October 1994;

- Phase II - wet excavation activities in Waste Pits 1,2 , and 3 - completed March 1995;

- Phase III - dewatering activities - completed in August 1995; and

- Phase IV - ramp and pad excavation - completed in October 1995.

Results of DEEP confirm that conventional excavation of the Waste Pits is feasible and can be done safely.

\section{OU2 Record of Decision Signed in June 1995}

The OU2 FS/PP underwent public comment from October 26, 1994, through January 20,1995. After the close of the public comment period, the Proposed 


\section{CERCLA Remedial Response Actions}

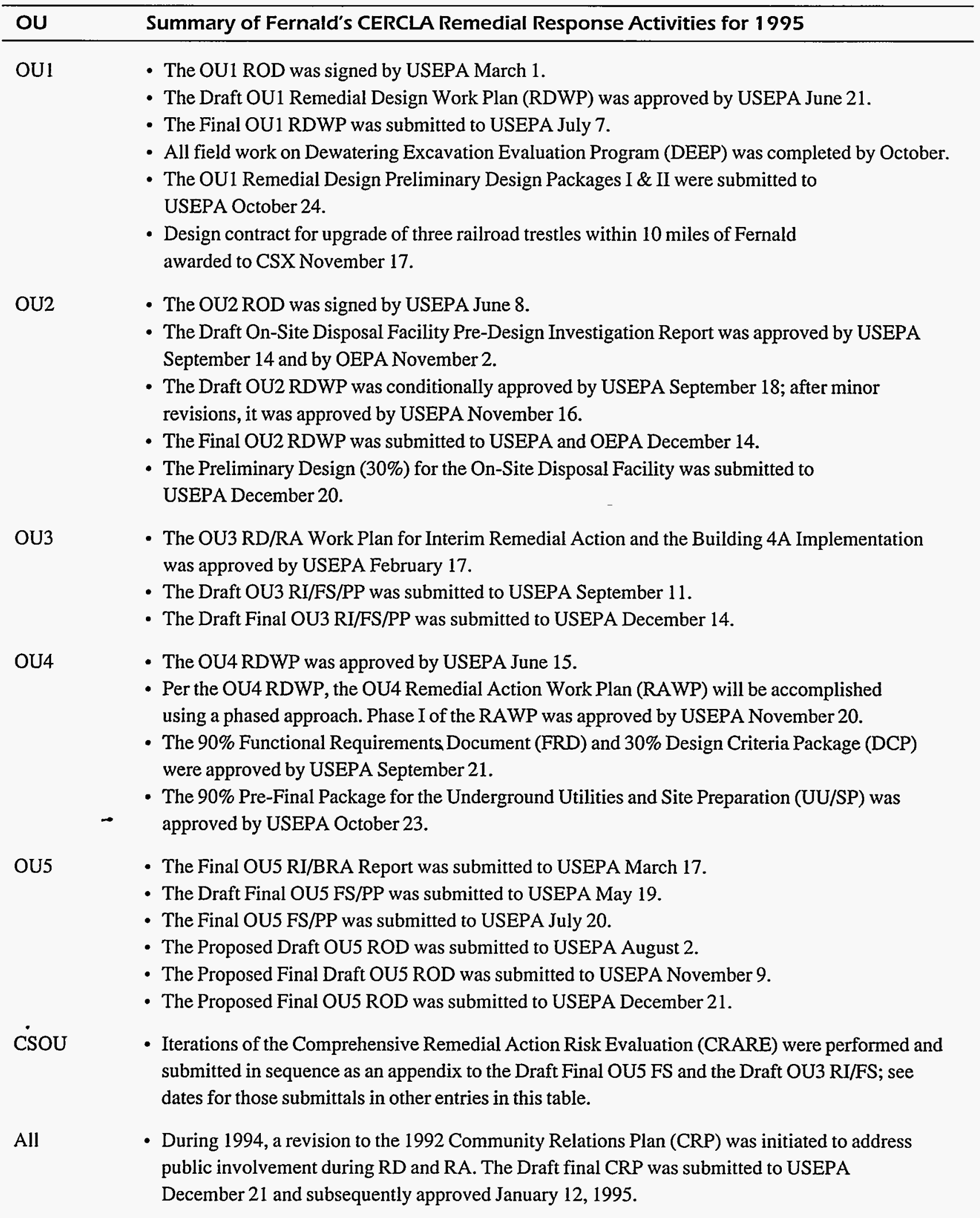


Draft OU2 ROD/RS was submitted to USEPA on February 3, 1995. After receipt of USEPA and OEPA comments on the Proposed Draft OU2 ROD, it was revised and submitted to USEPA and OEPA on April 8, 1995, and was signed by USEPA on June 8,1995 . The selected remedial action, as presented in the OU2 ROD, is excavation and onsite disposal of waste materials in an engineered facility. Consensus on this remedial action was reached not only through review by USEPA and OEPA but also through an active stakeholder involvement process which is implemented at Fernald.

The Pre-Design Investigation and Site Selection Report for the On-Site Disposal Facility was approved by USEPA on September 14, 1995, and by OEPA on November 2, 1995. This document established the location of the onsite disposal facility. The OU2 Remedial Design Work Plan was approved by OEPA on November 2, 1995, and by USEPA on November 16, 1995.

A contract for design of the On-Site Disposal Facility was awarded to GeoSyntech on August 11, 1995. The Preliminary (30\%) Design for the On-Site Disposal Facility was submitted to USEPA and OEPA for review on December 20, 1995.

\section{OU3 Record of Decision for Interim Remedial Action Signed in July 1994}

Design plans and specifications for performing the interim remedial action are in progress. USEPA approved the OU3 RD/RA Work Plan for Interim Remedial Action, and the Building 4A Implementation Plan for the dismantling of Plant 4, on February 17, 1995.

The Draft Plant 1 Complex - Phase I Implementation Plan for the dismantling of eight components of Plant 1 was submitted to the regulatory agencies on November 3, 1995. Comments from each were received in December 1995, and the Draft Final Implementation Plan is to be submitted to USEPA and OEPA in January 1996. USEPA has given conditional approval to the plan, while OEPA has fully approved it.

\section{OU3 Remedial Investigation, Treatability Studies, and Feasibility Study}

As agreed to by both USEPA and OEPA, a streamlined RI/FS Report was prepared to support the decision on final disposition of materials removed during the decontamination and dismantling of the former production buildings, structures, and equipment. The Draft Combined OU3 RI/FS was submitted to USEPA September 11,1995 , approximately 11 months in advance of the previously expected date of August 1996. The Draft Final combined OU3 RI/FS was submitted to USEPA on December 14, 1995.

The anticipated submittal date for the Proposed Draft OU3 ROD for Final Remedial Action has been accelerated nine months, from April 1997, to July 1996. 


\section{OU4 Remedial Design Work Plan Approved in June 1995}

The selected OU4 remedial action, as presented in the OU4ROD (signed by USEPA on December 7,1994), is to remove and vitrify the contents of Silos 1-3and the decant sump tank, then ship the vitrified waste for disposal at the DOE Nevada Test Site (NTS).

The OU4 Remedial Design Work Plan was approved by the USEPA on June 15, 1995. Per the RDWP, a phased approach will be utilized for accomplishing the Remedial Action Work Plan. Phase I of the RAWP includes activities that support construction of the Fernald Residues Vitrification Plant (FRVP). These activities include underground utilities and site preparation, silo superstructure construction, and construction of the new radon treatment system. Phase I of the RAWP was approved by USEPA on November 20, 1995. The 90\% Pre-final package for the Underground Utilities and Site Preparation was approved by USEPA on October 23,1995.

Two other documents were approved by USEPA in support of OU4 activities in 1995; both the 30\% Design Criteria Package and the 90\% Functional Requirements Document were approved September 21, 1995.

\section{Vitrification Pilot Plant}

Construction of the OU4 Vitrification Pilot Plant continued through 1995. The purpose of the facility is to conduct a larger scale (one ton per day) test of the feasibility of vitrifying the silo waste materials by conducting two phases of operation. Phase I will demonstrate vitrification of inert surrogate material. Phase II will demonstrate and optimize vitrification of actual K-65 (Silos 1 and 2) and Silo 3 material. This test facility will allow DOE to better define remediation costs and engineering design for final remediation of the silos. Phase I operation of the test facility is scheduled to begin in mid-1996.

\section{OU5 Feasibility Study/Proposed Plan and Record of Decision}

The Draft Final Feasibility Study/Proposed Plan (FS/PP) report, reflecting changes made to incorporate comments, was submitted to USEPA and OEPA on March 23, 1995. After addressing additional comments from USEPA and OEPA, the Final OU5 FS/PP was submitted to USEPA and OEPA on July 20, 1995.

The OU5 FS/PP underwent public comment from May 1 through 31, with an extension through June 30, 1995. After close of the public comment period, the Proposed Draft OU5 ROD/RS was submitted to USEPA and to OEPA for concurrence, on August 2, 1995. After receipt of USEPA and OEPA comments on the Proposed Draft OU5 ROD, it was revised and the Proposed Final Draft submitted November 9, 1995. After approval from USEPA, the Draft Final OU5 ROD was revised to Proposed Final, signed by DOE, and submitted to USEPA and OEPA on December 21,1995 . The selected remedial action for OU5 consists of excavation of contaminated soil, placement of the soil in an on-property disposal facility, and the restoration of the Great Miami Aquifer to its full beneficial use by pumping and treating contaminated groundwater. 


\section{Advanced Wastewater Treatment System}

Construction of the Advanced Wastewater Treatment (AWWT) system was completed on schedule, and the facility became operational in January 1995 as planned. The objective of the AWWT is to provide advanced treatment of stormwater runoff and wastewaters for the removal of uranium prior to discharge from the site.

In addition, preliminary engineering efforts examining the viability of expanding the AWWT system to address groundwater removed as part of future remedial actions have been completed. This work supported development of the OU5 FS. More detailed engineering on the expansion of the AWWT to address future groundwater remedial actions is now in progress.

\section{CERCLA Removal Response Actions}

In the course of RI or FS efforts, certain conditions are occasionally identified which call for more immediate action to abate an imminent threat to health and the environment, including actions necessary to monitor, assess, or evaluate the health threat. These actions are called "removal actions" and are initiated when there is a need to accelerate cleanup activities to address releases or potential releases of hazardous substances. Removal actions are coordinated with USEPA and OEPA.

An overall completion status summary of Fernald removal response actions is presented below. Brief descriptions of those actions are then presented, organized first by completion status, and then by removal action number. An overall summary of the scope and status of all CERCLA removal response actions at Fernald is then presented. Removal actions that were conducted as combined RCRA Closures/CERCLA Removal Actions in 1995 are addressed later in this chapter under RCRA Closures.

\begin{tabular}{|c|c|c|c|}
\hline \multicolumn{4}{|c|}{ Fernald Removal Actions Completion Summary } \\
\hline Status & Count & \# & Title \\
\hline Previously completed & 22 & & \\
\hline \multirow[t]{2}{*}{ Completed in 1995} & 2 & 1 & Contaminated Water Beneath FEMP Buildings \\
\hline & & 30 & Seepage Control at the Southfiled and Inactive Flyash Pile \\
\hline \multirow[t]{8}{*}{ Ongoing } & 8 & 3 & South Groundwater Contamination Plume \\
\hline & & 9 & Removal of Waste Inventories \\
\hline & & 12 & Safe Shutdown \\
\hline & & 15 & Scrap Metal Piles \\
\hline & & 17 & Improved Storage of Soil and Debris \\
\hline & & 20 & Stabilization of UNH Inventories (HWMU Nos. $46-50)^{\prime}$ \\
\hline & & 26 & Asbestos Removals \\
\hline & & 28 & Contamination at the Fire Training Facility (HWMU No. 1) ${ }^{1}$ \\
\hline Total & 32 & & \\
\hline
\end{tabular}

\footnotetext{
Key

'Done as combined RCRA Closure/CERCLA Removal Action
} 


\section{Completed in 1995}

\section{Removal Action No. 1 - Contaminated Water Beneath FEMP Buildings}

Perched groundwater zones beneath some former production buildings are of concern due to significant concentrations of uranium and volatile organic compounds. To minimize the potential for the movement of contaminated water to the underlying Great Miami Aquifer, fourteen wells were installed to extract the perched groundwater for treatment. Pumping was scheduled to continue until final remedation plans were established. Part of the preferred alternative for OU5 includes excavation of contaminated perched groundwater zones within the glacial overburden, concurrent with the soil remediation activities; therefore, the need for continuing pumping of the perched zone as an on-going removal action was reevaluated. This re-evaluation indicated that discontinuing the pumping would not impact the Great Miami Aquifer, and the cost savings from discontinuing Removal Action 1 could be targeted toward more benefical activities. After approval from OEPA and USEPA, pumping of perched groundwater beneath site buildings ceased in December 1995.

\section{Removal Action No. 30 - Seepage Control at the South Field and Inactive Flyash Pile}

This removal action collected contaminated sediment and seepage from the South Field and Inactive Flyash Pile in order to protect the Great Miami Aquifer. The Final Work Plan for Removal Action No. 30 was submitted to USEPA and OEPA on April 8, 1995, and construction began on April 25, 1995. The system was operational on August 16,1995, and the Final Report was submitted to USEPA and OEPA on December 7, 1995.

\section{Removal Actions Ongoing (Excluding Combined RCRAVCERCLA Activities)}

\section{Removal Action No. 3 - South Groundwater Contamination Plume}

Past operations at the site have resulted in a uranium contamination plume (the South Plume) in the Great Miami Aquifer at a location south of the site property. Removal Action No. 3 was initiated to prevent or minimize the further migration of the South Plume and to mitigate the effects of the contamination on local groundwater users. To date, the main body of the South Plume continues to be captured by a recovery well system. Further optimization of the recovery well system will occur according to the remedial design/remedial action schedules for OU5.

\section{Removal Action No. 9 - Removal of W/aste Inventories}

This removal action involves the characterization, overpacking, and disposition of low-level radioactive waste materials. Fernald continues to operate an aggressive 
waste shipping program which began in 1985; 1995 waste shipping activities are listed in the table on the next page.

Several mixed waste treatment projects are being conducted under Removal Action No. 9 and in accordance with Director's Findings and Orders issued by OEPA on October 4, 1995. These waste streams are being treated to meet RCRA land disposal restrictions (LDR) and will be shipped offsite for final disposition after treatment is complete.

\section{Removal Action No. 12 - Safe Shutdown}

This removal action was initiated to ensure the safe and permanent shutdown of production facilities in the former production area. This includes the removal of uranium and other process/raw materials and waste materials from equipment, lines, and ductwork. Materials removed are packaged for disposition.

Several Safe Shutdown programmatic responsibilities have been reassigned to Waste Programs Management. These include the programmatic responsibility for equipment location verification, relocation of excess production equipment within the DOE complex and the private sector, and the sale of depleted uranium metal derbies. The Safe Shutdown program works closely with Waste Programs Management in this ongoing effort.

Concurrent with safe shutdown activities, redistribution of utilities for the Plant 9/ Thorium Complex are underway. Plant 5 safe shutdown activities are planned to begin January 1996, now that relocation of 2,500 drums of enriched restricted material to a tension support structure on the Plant 1 Pad has been accomplished. Safe shutdown activities, including utility disconnections and holdup material in the Pilot Plant, are ongoing.

\section{Removal Action No. 15 - Scrap Metal Piles}

Plans are being finalized for the removal and offsite processing of the containerized scrap copper pile. This portion of the project is currently on hold until a treatability/engineering study is completed. A contract for conducting this engineering study on 30 tons of scrap copper wire containing asbestos insulation was awarded to Manufacturing Sciences Corp. of Oak Ridge, Tennessee, and is expected to be completed mid-summer 1996.

\section{Removal Action No. 17 - Improved Storage of Soil and Debris}

This removal action was initiated to address contaminated soil and debris generated as a result of continued construction and maintenance projects, removal actions, and remedial actions at Fernald. Field implementation activities originally included four separate actions: the construction of three temporary interim storage structures (similar to those currently being used on Fernald's Plant $1 \mathrm{Pad}$ ), and the in-place containment of one existing large soil and rubble pile. These four field actions were to be implemented to improve interim storage and management of 


\begin{tabular}{llc}
\hline \multicolumn{2}{c}{$\begin{array}{l}\text { Fernald's } 1995 \text { Removal of Waste Inventories Under Removal Action No. 9 } \\
\text { Destination }\end{array}$} & $\begin{array}{c}\text { Drum Equivalents } \\
\text { Dategory }\end{array}$ \\
\hline Uranium production residues & DOE Nevada Test Site, NV & 19,474 \\
Process area scrap & DOE Nevada Test Site, NV & 36,729 \\
Construction and removal action waste & DOE Nevada Test Site, NV & 24,495 \\
Contaminated trash & DOE Nevada Test Site, NV & 2,917 \\
Thorium & DOE Nevada Test Site, NV & 713 \\
Armament Munitions Chemical Command waste & DOE Nevada Test Site, NV & 3,878 \\
\multicolumn{1}{c}{ Destination subtotal, Calendar Year 1995 } & 84,328 \\
Recyclable steel & Alaron & 13,046 \\
Liquid Mixed Waste Project & TSCA Incinerator & 870 \\
Non-LDR Project & Envirocare & 313 \\
\multicolumn{1}{c}{ Total to Offsite, Calendar Year 1995} & & 98,557 \\
& & \\
\hline
\end{tabular}

\begin{tabular}{cc}
\hline Fernald's 1995 Waste Treatment Activities Under Removal Action No. 9 \\
Mixed Waste Treatment Project & Quantity of Waste Treated in $\mathrm{m}^{3}$
\end{tabular}

$\begin{array}{lc}\text { Fernald Mixed Waste Stabilization Project } & 332.4 \\ \text { UNH Neutralization System Project } & 761 \\ \text { HF RCRA Closure } & 19.7 \\ \text { Liquid Mixed Waste Project } & 16 \\ \text { Thorium Nitrate Treatment Systems } & 22\end{array}$

Total Treated, 1995

contaminated soils and debris to mitigate the potential spread of contamination until their final disposition is determined under the OU5 and OU3 RODs, respectively.

Fernald requested and received USEPA approval to cancel the planned construction of the three planned temporary covered storage structures and to pursue more viable alternatives. These changes are the result of a re-evaluation of evolving waste and debris management methodologies and public concerns regarding the construction of additional storage structures at Fernald — a Superfund site planned for total remediation.

Fernald is revising the removal action work plan to develop an interim site-wide soil and debris management program, in order to facilitate integrated implementation of Fernald's RODs, as well as individual remedial action plans, prior to disposition of the remedial-action- or removal-action- generated waste at the On-Site Disposal Facility (OSDF) or at an approved offsite treatment/disposal facility. The revised removal action work plan will be effective until the OSDF is operational and the appropriate remedial action plans are implemented. The Draft Revision 3 of the Removal Action 17 Work Plan was submitted to the agencies on October 10,1995, and will be submitted again in January 1996, in response to 
comments received in November 1995 and December 1995. Additionally, the revised work plan included the final report on the completed field actions conducted at the Soil and Rubble Pile North of Third Street and Scrap Metal Pile Residue/Debris Removal; the agencies approved the final report section of the work plan.

\section{Removal Action No. 26 - Asbestos Removals}

This removal action documents the ongoing asbestos abatement activities at Fernald to manage asbestos in-place and mitigate the potential for asbestos fiber release and migration. Abatement activities within the ongoing asbestos program include repairs, encasement, encapsulation or removal of asbestos containing materials that exist in many buildings on the Fernald site. Abatements to date include small-scale in-situ repairs, encasement, encapsulation, removals, and the completion of the large-scale asbestos abatement. Field activities in support of asbestos abatement are continuing, including the removal of asbestos-bearing thermal insulation in pipes, tanks, and valves throughout the Fernald site.

\section{Resource Conservation and Recovery Act}

\section{Stipulated Amendment to Consent Decree (SACD)}

The Stipulated Amendment to Consent Decree (SACD) requires that the site identify all Hazardous Waste Management Units (HWMUs) at the facility. As a result, burners, incinerators, furnaces, stills, process equipment, tank units, dust collectors, and other potential waste containment units were evaluated to determine if these units were HWMUs or Solid Waste Management Units (SWMUs). In 1995, the site continued to review the evaluation process, regulatory basis, and technical assumptions used to determine whether the designation of these units as HWMUs was justified. OEPA approval is being sought to change the designation for several HWMUs to SWMUs. In 1995, the site received approval from OEPA to reclassify four HWMUs to SWMUs (see page 72 for list). Closure activities continued for other HWMUs. Ohio EPA determined that six HWMUs were closed in accordance with Ohio EPA regulations. Field activities were completed for an additional four HWMUs. Refer to the table of HWMU Closure Activities on page 72 for further information.

\section{Changes/Additions to Wastestreams in 1995 Facility RCRA Annual Report}

The 1994 RCRA Annual Report reported 368 hazardous wastestreams and 92 pending wastestreams in storage. The 1995 RCRA Annual Report identified 358 hazardous wastestreams in storage. Sixty-two pending wastestreams are not included in the 1995 RCRA Annual Report because these wastestreams are no longer designated as hazardous waste in the site inventory and are not assigned EPA waste codes until characterization is completed. Fifty-five new hazardous wastestreams were added to the 1995 RCRA Annual Report. The 95 remaining wastestreams from the 1994 RCRA Annual Report which were not reported in storage in 1995 were dispositioned as follows: 
- 31 have been recharacterized as non-RCRA (17 of these were listed in 1994 as pending);

- 20 were bulked and shipped to the TSCA Incinerator;

- 18 were bulked and are currently stored in tanks onsite until shipped to the TSCA Incinerator;

- 13 have been categorized as nuclear product material;

- 6 have inventory only in satellite accumulation areas;

- 3 were treated onsite;

- 2 were originally generated and shipped from offsite; and

- 2 have been archived into other wastestreams.

The total amount of waste stored onsite has decreased through the above changes by $48 \%$. Total quantities of hazardous waste are presented below for calendar years 1994 and 1995 .

\begin{tabular}{lcccc}
\hline Category & 1994 & 1995 & Decrease & Decrease, \% \\
\hline Hazardous waste & $5,589,067 \mathrm{lbs}$. & $2,914,759 \mathrm{lbs}$. & $2,674,308 \mathrm{lbs}$. & 48 \\
& & & & \\
\hline
\end{tabular}

\section{Thorium Management}

A Thorium Management Strategy and schedule of accomplishments were developed as part of the SACD to provide a plan to complete RCRA determinations of thorium materials and to improve the storage of thorium materials at the Fernald site. The Thorium Management Strategy was initiated as part of the SACD and is based on three primary objectives:

- To maintain environmentally stable interim storage of the thorium inventory while minimizing personnel radiation exposure;

- To implement required further actions to complete RCRA evaluations of the thorium materials; and

- To implement long-term storage and disposal alternatives.

In 1995, the Fernald site shipped 776 drum equivalents of thorium material to the NTS for disposal. Additional shipments are planned for 1996.

\section{RCRA Closures}

During 1995, activities were underway to plan and implement the closure of Fernald's Hazardous Waste Management Units (HWMUs). Many of these activities consisted of proposing, obtaining OEPA approval for, and implementing several RCRA closure actions in conjunction with the CERCLA response actions being undertaken under the Amended Consent Agreement with USEPA. RCRA closure activities during calendar year 1995 are presented in the following table. Six HWMUs were closed in accordance with OEPA regulations. They are denoted in the table by shading. Additionally, field activities were completed for four HWMUs; they are marked with a double asterisk (*) following their identifying number. 
$1 \quad$ Fire Training Facility:

Conducted as a combined RCRA Closure/CERCLA Removal Action (Removal Action No. 28).

RAWP1/CPID ${ }^{2}$ originally submitted in September 1993, resubmitted February 10, 1994. Field work began July 1994 and continued in 1995.

$3 * * \quad$ Waste Oil Storage in Garage:
Field work completed in 1995. CPID approval received from OEPA on December 28, 1995. Clo-
sure certification to be submitted in 1996.

4*: Drum Storage Area Near Lab Loading Dock:
NOD ${ }^{3}$ for the CPID received from OEPA February 1, 1994. Revised CPID submitted to OEPA
March 3, 1994. A large part of the HWMU was excavated as part of a CERCLA Removal Action
and the lab building extension. Closure field work was completed in 1995.

6 Drummed Hydrofluoric Acid (HF) Storage Inside Plant 4:

Closure certification acceptance received from OEPA on April 28, 1995.

8 Drummed HF Residue Cooling Tower:

Clean closure acceptance from OEPA received April 13, 1995.

9

Nitric Acid Rail Tank Car and Surrounding Area:

Conducted as a combined RCRA Closure/CERCLA Removal Action (Removal Action No. 25). Combined RAWP/CPID submitted to OEPA in March 1993. Removal Action Final Report and completion of closure certification submitted October 31, 1994 and approval received from OEPA on April 25, 1995.

$13 * * \quad$ Wheelabrator Dust Collector:

CPID submitted to OEPA July 18, 1994. Field work completed in 1995.

22 Abandoned Sump West of Pilot Plant:

Conducted as a combined RCRA Closure/CERCLA Removal Action (Removal Action No. 24).

Removal of the sump completed October 12, 1993. Duriron pipe plugged and the area backfilled. USEPA approved Removal Action Final Report January 14, 1994. The soil, liquid, sump, associated piping, and pump currently stored onsite in a RCRA storage area as mixed waste. Soil remediation addressed via the CERCLA remediation process.

26 Detrex Still:

Closure certification acceptance received from OEPA on November 27, 1995.

\section{1/32 Bulk Storage Tanks T-5 and T-6:}

Field work progressed through 1994. Tanks T-5 and T-6, and the secondary containment under them, are clean in accordance with the CPID; however, because they share a common secondary containment with HWMU 54 (Tank T-2), closure certification is contingent upon Tank T-2 closure.

Field work completed in 1995; closure certification acceptance received from OEPA on November $27,1995$.

46-50 Uranyl Nitrate Hexahydrate (UNH) Tanks:

Conducted as a combined RCRA Closure/CERCLA Removal Action (Removal Action No. 20). USEPA approved RAWP August 9, 1994. Field work on all tanks completed in 1995 with the exception of Tanks F1-25 and F1-26. Decontamination of F1-25 and F1-26 scheduled for completion in 1996. 
52** North and South Spent Solvent Tanks:

Work initiated in 1994. Field activities for steam cleaning the tanks completed June 1994. Comments received from OEPA December 5, 1994. Revised CPID approved by OEPA on September $12,1995$.

53 Safe Geometry Digestion Sump:

Field work completed September 27, 1994. Sump is clean and capped. No formal closure plan required by OEPA, but a letter describing field activities submitted to OEPA February 13, 1995.

54 Thorium Nitrate Tank T-2:

Declared a HWMU June 1994, as a result of exceeding the 90-day storage of a hazardous waste, based on corrosivity (D002), cadmium (D006), and chromium (D007). Completed processing of tank's contents in 1995 as part of CERCLA Removal Action No. 9. Final report to be submitted in 1996.

\footnotetext{
'Removal Action Work Plan

2Closture Plan Information and Data

"Notice of Deficiency
}

During 1995, four HWMUs were reclassified as Solid Waste Management Units (SWMUs). They are the Wheelabrator Shotblaster (\#12), the Primary Calciner (\#16), the Bio-Surge Lagoon (\#40), and the Experimental Treatment Facility (\#51).

\section{RCRA Routine Groundwater Monitoring Program - Director's Final Findings and Orders}

This Director's Final Findings and Orders (DF\&O), signed September 10, 1993, describes an alternate groundwater monitoring system with a routine monitoring program that allows hazardous waste monitoring requirements to be fulfilled by the CERCLA process already in progress. This resolves the integration difficulties involving the state hazardous waste facility groundwater monitoring regulations and the CERCLA requirements at the Fernald site. Findings of the 1995 sampling and analyses from this routine groundwater monitoring program, as presented in the 1995 RCRA Annual Report, indicate that other than the contamination comprising the South Plume, there are no concentrations of contaminants detected at the routine monitoring program well locations that trigger the need for action ahead of the final OU5 groundwater remedy. The contamination comprising the South Plume is observed in two routine monitoring program wells and is presently being addressed by Removal Action No. 3 - South Groundwater Contamination Plume. These findings are consistent with those indicated in the OU5 Remedial Investigation Report.

\section{Removal of Site Product Inventories}

In June 1995 a contract was signed with AlliedSignal, Morristown, New Jersey, for 671,777 net pounds of normal uranium tetrafluoride (UF4) and 19,908 net pounds of uranium trioxide (UO3). The first shipment was made on September 7, and the remaining shipments were completed approximately six weeks ahead of schedule 
on November 9. Normal uranium contains 0.711 percent of naturally-occurring uranium 235. AlliedSignal will use the raw material at its Metropolis, Illinois, facility to produce uranium hexafluoride (UF6) for commercial customers. A total of 677,232 net pounds were shipped against this contract (shortage was due to outof-specification materials).

In November 19, 1993, a contract was signed with Manufacturing Sciences Corporation, Oak Ridge, Tennessee, for 973,651 net pounds of depleted uranium derby metal. Shipments began on January 25, 1994, and have been shipped at the rate of one load (approximately 37,000 net lbs) per month. The customer has until December 1996 to remove all of the material from the Fernald site.

The table belows shows a breakdown of these product inventories as they were shipped in 1995.

Category

Normal green salt Normal orange oxide Depleted uranium derbies
Fernald's 1995 Removal of Site Product Inventories Destination Quantity Shipped in Lbs.
AlliedSignal

AlliedSignal

Manufacturing Sciences Corp.
657,487

19,745

370,527
Total to Offsite, Calendar Year 1995

\section{Safety \& Health Self-Assessment Program}

Self-assessment is a quality assurance and continuous process improvement function that identifies strengths and weaknesses of programs, policies, and procedures in order to provide opportunities for improvement. The Safety \& Health (S\&H) Self-Assessment Program has been established to encompass all programs, departments, and sections within the S\&H Division. Assessment activities consist of performance- and compliance-based assessments conducted against applicable DOE Orders, regulations, and procedures pertaining to the functional area programs being assessed. Assessments are performed in order to determine the reliability, adequacy, and compliance of S\&H programs with identified requirements. The program includes all appraisals, surveillances, audits, and walkthroughs conducted on S\&H activities by both internal personnel and external agencies.

In 1995, 50 assessments were performed in such varied areas as Emergency Preparedness, Industrial Hygiene, Fire Protection, Document Control, and Safety Analysis.

\section{Compliance Verification Program}

In 1995, the Environmental Compliance Division (EC) organized a new department, Compliance Verification, tasked with reviewing ongoing site activities to assess compliance with applicable requirements contained in federal and state environmental regulations and DOE Orders. 
Compliance Verification Department activities are intended to assess the regulatory adequacy of current site practices and conditions, identify potential areas of improvement, determine the underlying cause(s) for any unsatisfactory condition, and assist in development of appropriate corrective actions.

The Compliance Verification Program includes two principal parts:

- Environmental Compliance Surveillances (ECSs), ongoing surveillance activities which involve the review of current operations for compliance with specific regulatory/DOE requirements, and

- Comprehensive Environmental Compliance Assessments (CECAs), designed to confirm the compliance of ongoing operational activities, removal actions, and remedial projects with all applicable conditions contained in EPA and DOE approved program plans, directives, and site procedures.

In 1995, Compliance Verification performed eight CECAs on topics ranging from broad areas such as Analytical Laboratory Services and Landlord Facility Operations to specific projects such as UNH Neutralization and Thorium Nitrate Solidification. A total of 20 ECSs were completed as scheduled, only four of which have issues still requiring further action.

\section{Stalkeholder Involvement}

The historical chronology of how the community became involved in site-related decisions and activities is detailed in Fernald's Community Relations Plan. This chronology demonstrates how increased stakeholder awareness prompted the DOE to move from the non-participatory "decide, announce, defend" strategy to the two-way approach of shared decision making. Through two-way communications, the DOE and its stakeholders work together toward the common goal of site remediation.

During 1995, the DOE invited and encouraged stakeholders to participate formally in decisions affecting the remediation of Operable Units 2 and 5. Interested stakeholders commented on the proposed plans for these operable units during formal public hearings. As a result, stakeholder input was considered by USEPA and OEPA during the approval processes for both of these Records of Decision.

During the year, stakeholder input regarding Fernald activities and issues was solicited through regular briefings for the local citizens environmental interest group [Fernald Residents for Environmental Safety and Health, (FRESH)] and local township trustees; person-to-person communication through the Fernald Envoy Program; workshops designed to provide information and solicit stakeholders' concerns; Fernald Visitors Bureau programs, including the speakers bureau and site tours; dissemination of various fact sheets; publication of the Fernald Report, a monthly community newsletter, and Fernald Progress, a bimonthly newsletter; and availability of other types of literature. In addition, mate- 
rials related to the Fernald decision-making process were also available to the community at the Public Environmental Information Center.

In addition to their own individual efforts, stakeholders had an opportunity to participate in and become informed about Fernald-related activities and issues through the Fernald Citizens Task Force. Established by the DOE in 1993, the Fernald Citizens Task Force is a site-specific advisory board that includes members who are local residents, local elected officials, and representatives of FRESH, DOE, USEPA, and OEPA.

\section{DOE Complex-wide Performance Indicator Status}

In July 1994, DOE and the prime contractor, FERMCO, signed a major modification to FERMCO's contract, representing the first significant action under DOE's contract reform initiatives nationwide. Performance based contracting, as outlined in this modification, is a significant departure from the management and operating $(\mathrm{M} \& \mathrm{O})$ type contract that DOE has traditionally awarded at other sites. The modified contract provides FERMCO a financial incentive for managing the environmental remediation process as efficiently as possible. Unlike M\&O type contracts, this contract requires FERMCO to accept financial responsibility for its actions at Fernald, including any fines or civil penalties that might arise from FERMCO's own negligence. In return, FERMCO is granted more authority to make aggressive decisions about remediation methods.

Under the new performance-based fee system, FERMCO and DOE agree upon a set of specific, measureable goals to be reached during a given six-month period. FERMCO earns bonus fee only when it exceeds those goals; satisfactory achievement of Perfomance Objectives and Criteria (POC) by itself is simply expected and no longer earns any fee. The system also can result in forfeiture of base fee if FERMCO fails to meet minimum performance requirements.

In addition to the Contract Reform recommendations, the Performance Based Fee Determination Plan also serves to align the Fernald site criteria with DOE's Environmental Management Vision. This Vision establishes goals to:

- Manage/eliminate urgent risks and inherent threats;

- Provide a safe workplace i.e., one that is free from accidents, injuries and adverse health effects;

- Improve the system through managerial and financial internal controls;

- Be more outcome oriented (as opposed to process oriented);

- Focus the Technology Development Program on major obstacles to progress and involve the best talent in the DOE and national science and engineering communities; and

- Develop a stronger partnership between the Department and its stakeholder.

The Performance Based Fee Determination Plan details two areas against which the Contractor is evaluated: (1) General Contract Performance, and (2) Milestone 
Completion. It provides the standardization necessary to ensure effective development, administration and coordination of all phases of the Performance Based Fee evaluation process which is divided into two fiscal year periods (October through March and April through September annually). DOE uses this Plan as one of several tools to evaluate the contractor's success in meeting requirements of the performance based environmental management contract. The contract stresses achieving programmatic goals safely, quickly, and at a reasonable cost through the use of innovative approaches. The objective of the previously mentioned Contract provisions is to afford the Contractor an opportunity to earn increased fee commensureate with the achievement of performance levels beyond those considered "satisfactory."

The Contractor's input is integral to the process of developing POCs and Milestones. The Contractor's input is particularly important since the performance goals established by DOE in the plan are aggressive. The goals are worded so that the standard for excellence is attainable, while requiring a well-managed and concerted effort on the part of the Contractor.

In addition to the special management emphasis in the General Contract Performance POCs and Milestones identified for each six-month plan, the Contractor receives incentives for attaining high standards of excellence as measured against performance standards consistent with best available practices. The plan is designed to motivate the Contractor to identify new problems to DOE, and to develop and implement effective and economical corrective actions.

The Performance Based Fee Plan does not have a large number of POCs; contractor performance is evaluated using objective, measurable and verifiable performance criteria tied to the three elements of the Fernald Mission Statement. The three Mission Statement elements used for evaluation of the Contractor during 1995 were Safe Clean-up (Environment, Public and Worker); Least-Cost, Earliest, and Final Clean-up; and Addressing Stakeholder Concerns.

This approach prevents "dilution" of the focus of the Plan and defines DOE's primary needs and expectations for Excellent performance, including goals of DOE Headquarters' Office of Environmental Management, as well as Fernald-specific goals. In addition to a number of established milestones, the contractor's performance was measured against the following POC's in 1995:

1. Safe Clean-up (Environment, Public and Worker):

1a. Timely Identification, Categorization and Control of Safety and Health Deficiencies,

1b. Radiological Protection Program,

1c. Reducing Radiological Occurrences,

1d. Continue Safety First/Employee Involvement/Voluntary Protection Program Activities,

1e. Subjective Evaluation of all Safety and Health Programs 
2. Least-Cost, Earliest and Final Clean-up:

2a. Small and Minority Business Participation,

2b. Property Management,

2c. Procurement Program Improvements,

2d. Cost Savings,

2e. Project Tracking System,

2f. Thorium Overpacking,

2g. Mixed Waste Treatment Project - TSCA Incinerator and Stabilization,

2h. Low-Level Waste Disposition,

2i. Newly Generated Low-Level Waste/Waste Minimization,

2j. Nuclear Material Disposition Project,

2k. Subjective Evaluation of Integration of Waste Management Safe Shutdown and Landlord Activities

21. Subjective Evaluation of Technology Development Program

3. Addressing Stakholder Concerns

3a. Subjective Evaluation of the Internal and External Stakeholder Program

\section{Summary of Permits}

The site was required to have five different types of Environmental Permits during calendar year 1995. These involved wastewater treatment, storage of RCRA waste, air emission sources, and wetland disturbances. One additional type of permit common to the Fernald site that was not needed in 1995 is a Water Permit to Install which is required for any new or substantial changes in the wastewater system.

Those permits required for 1995 are identified in the following table.

\begin{tabular}{|c|c|c|c|c|}
\hline \multicolumn{5}{|c|}{ Summary of Permits } \\
\hline Type of Permi & & Issuing Agency & Permit Number & Comments \\
\hline NPDES & 1 & USEPA & $\mathrm{OH} 11 \mathrm{IO} 00004 * \mathrm{ED}$ & Permit includes stormwater. \\
\hline RCRA TSD & 1 & USEPA & OH6890008976 & $\begin{array}{l}\text { Part A \& B permit applications are } \\
\text { on file. }\end{array}$ \\
\hline $\begin{array}{l}\text { Air Permit to } \\
\text { Operate (PTO) }\end{array}$ & 101 & OEPA & Premise No. 1431110128 & $\begin{array}{l}\text { Many of these PTOs are permits which, } \\
\text { although they are technical active, corre- } \\
\text { spond to equipment that is no longer in } \\
\text { operation. All other Air PTOs will be } \\
\text { replaced in } 1996 \text { by a sitewide Title V } \\
\text { permit. }\end{array}$ \\
\hline $\begin{array}{l}\text { Air Permit to } \\
\text { Install (PTI) }\end{array}$ & 3 & OEPA & $\begin{array}{l}14-3348 \\
14-3394 \\
14-3863\end{array}$ & $\begin{array}{l}\text { Respirator Wash Facility } \\
\text { Gasoline Dispensing Facility } \\
\text { Three gas/oil fired boilers with a } 10,000 \\
\text { gallon storage tank }\end{array}$ \\
\hline $\begin{array}{l}\text { Wetland } \\
404 / 401\end{array}$ & 2 & Corps of Engineers & N/A & Issued under National Permit No. 26. \\
\hline
\end{tabular}


AIR PATHWAY
MONITORING

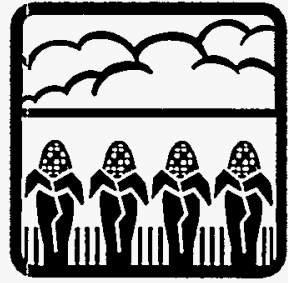





\section{Air Pathway Monitoring}

This chapter describes the air pathway components that may become contaminated as a result of airborne emissions from the site. Although it is not a true component of the air pathway, a discussion of the direct radiation monitoring program and results are included here for convenience.

As discussed in Chapter One, the public may be exposed to radiation from the site through the air pathway. This includes emissions from specific point sources, such as plant stacks, as well as dust from large, open areas, such as the waste pits area. When production operations were suspended in mid-1 989, the major point source emissions from the site were eliminated. Since then, the principal sources of airborne uranium emissions have been the cooling tower mists, which have low levels of uranium contamination,

\section{Fugitive Dust}

The term fugitive dust is used to describe the small amounts of contaminated soil, waste materials, and construction dusts released from the Fernald site as a result of ongoing remediation work. Sources of fugitive dust at the Fernald site include: dust generated as contaminated material is moved or repackaged; small amounts of soil carried away by the wind during the excavation of a trench; wind erosion of waste pit materials which are not covered by water; and soil erosion during dry, windy weather. Dust from construction and remediation activities, waste handling and wind erosion are also important potential sources of pollutants. and fugitive dust from locations where environmental remediation activities are underway.

Air pathway monitoring focuses on airborne pollutants that may be carried from the Fernald site as a particulate or gas and how these pollutants are distributed in the environment. The form and chemical makeup of pollutants influence how they are dispersed in the environment and how they may deliver radiation doses. For example, fine particles and gases remain suspended, while larger, heavier particles tend to settle and deposit on grass or soil. Chemical properties determine whether the pollutant will dissolve in water, be absorbed by plants and animals, or settle in sediments and soils. 


\section{Results in Brief: 1995 Air Pathway}

Air - Data collected from fenceline air monitoring stations show that average concentrations of uranium were all less than $1 \%$ of the DOE standard. Airborne uranium emissions for 1995 were estimated to be $3.5 \mathrm{~kg}$.

Soil -Some on-and off-site soil samples continue to indicate elevated uranium concentrations due to deposition of airborne particles from past operations. One off-site sampling location, in the predominant wind direction northeast of the site, had a total uranium concentration of $6.0 \mathrm{pCi} / \mathrm{g}$, which is above the background level of $2.8 \mathrm{pCi} / \mathrm{g}$ for the Fernald area.

Grass-The 1995 results indicate uranium concentrations are within the range of historical concentrations and suggest 1995 emissions have not significantly affected uranium concentrations in grass.

Produce - Uranium concentrations in produce were consistent with previous years' data. Laboratory analyses did not detect any significant differences in uranium concentrations between produce grown near the plant and produce grown at outlying locations.

Milk-Uranium concentrations from the local dairy are comparable to those from background concentrations from a dairy in Indiana. The data demonstrate milk from the local dairy is not affected by site emissions. This program was discontinued in March 1995, with the sale of the local dairy.

Direct Radiation-Measurements of direct radiation indicate levels increase with proximity to the $\mathrm{K}-65$ silos. However, these levels are $80 \%$ lower than radiation levels measured in 1991 prior to the addition of the bentonite layer within the K-65 silos. These measurements are consistent with the fact that the silos contain radium and its decay products which contribute to the direct radiation in the vicinity.

Boiler Plant - With the exception of short-term opacity excursions, all emissions were well below permit limits. 


\section{Monitoring for Radioactive Pollutants}

During 1995, Fernald site personnel continued to monitor radioactive materials in the air pathway by sampling air, soil, grass, produce, and milk. This monitoring enables scientists to evaluate the effects of the remediation efforts at the site and fulfill the site's obligations toward ongoing environmental surveillance and dose estimating.

\section{Air Sampling for Radioactive Particulates}

The first step in monitoring the air pathway is measuring the emission rate of the pollutants at the point of release after they have gone through treatments and filtering. This is done by means of stack sampling, and it provides preliminary information on how much pollutant is released and how it will behave in the environment. The second step in air pathway monitoring involves measuring the pollutant concentration in ambient air onsite and at the site boundary. Because only a few stacks and vents continue to emit pollutants at the site, airborne emissions from monitored stacks are substantially lower than those during the years of production. However, monitoring of overall site emissions (stack and fugitive emissions) continues through the use of air monitoring stations (AMSs) located onsite, near the site fenceline, and at several locations in nearby communities.

Airborne pollutants are subject to existing weather conditions; thus, wind speed and direction, rainfall, and temperature play a role in predicting how pollutants are distributed in the environment. Weather data, particularly wind speed and direction, provide input for selecting locations to collect environmental samples and locating monitoring stations.

During 1995, the site operated 20 air monitoring stations 24 hours a day, seven days a week, as part of the Air Monitoring Program. Scientists selected the locations for the AMSs, as shown in Figure 22, for several reasons:

- AMS 1 was moved to a location closer to the former production area in mid-1993, in order to comply with DOE and EPA monitoring criteria. The new location was designated AMS $1 \mathrm{~A}$ and is no longer on the site boundary.

- AMS 2 through AMS 7 provide data at the fenceline because this is where the public has closest access to the site, and guidelines for offsite exposure apply.

- AMS 8 and AMS 9 are in the prevailing wind direction at the site. They were added in 1986 to the northeast sector of the site based on a computer model that predicted where the highest ground-level concentrations of airborne uranium from plant operations would be found. In mid-1994, AMS 9 was moved to a location just outside of the production area. The new location was designated AMS $9 \mathrm{~A}$ and allows easier access to the monitor for maintenance and filter collection. 


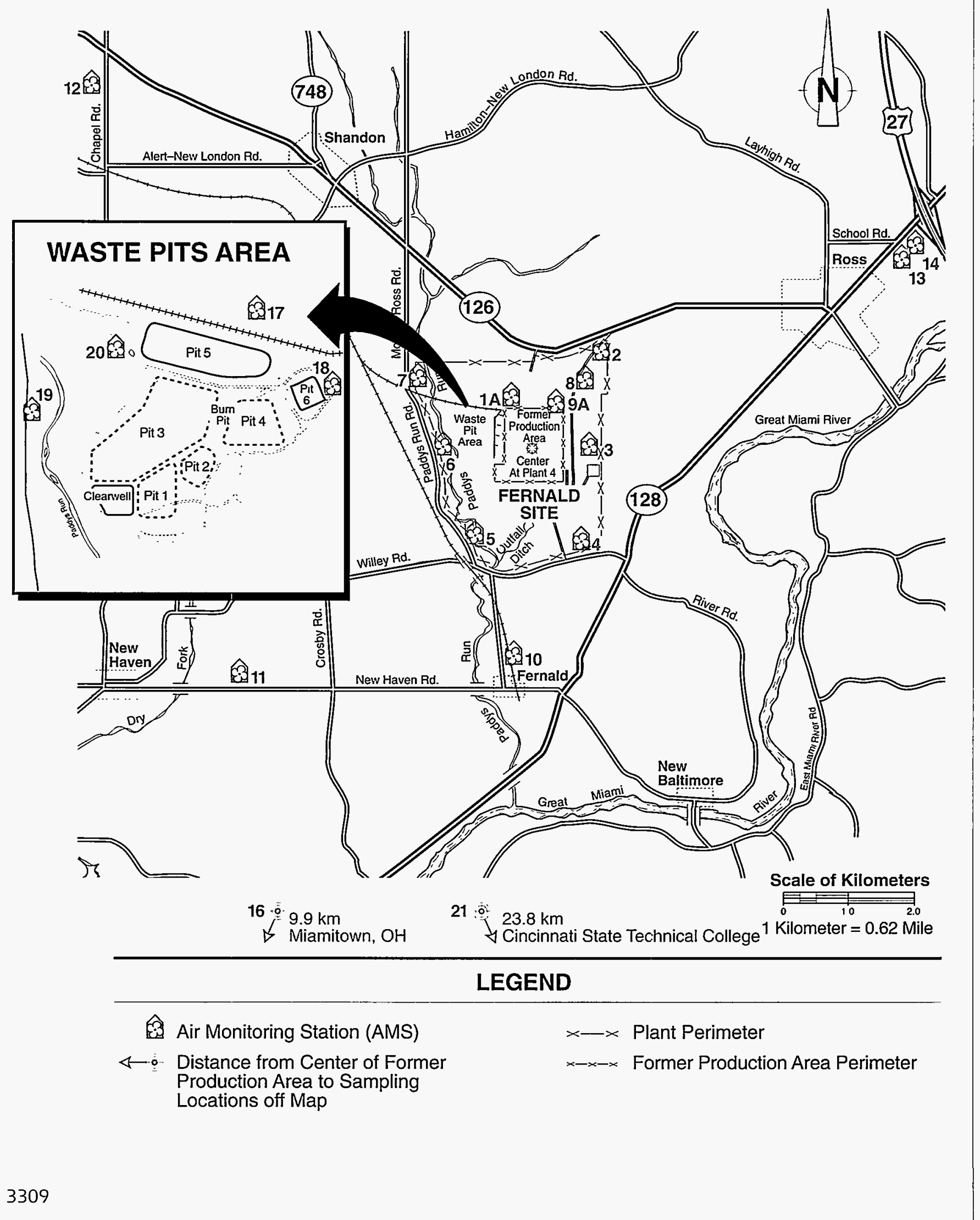




\section{Method Used to Determine Airborne Emissions}

The total airborne uranium emissions are determined by summing the estimated and measured emissions from a number of stacks, vents, and processes on site. Measured and estimated uranium emissions for 1995 totaled $3.5 \mathrm{~kg}(7.7 \mathrm{lbs})$. Uranium discharges from monitored stacks were the only measured emissions. Emissions from all other sources listed here were estimated. Airborne emissions are expected to remain at low levels for several years. However, a future increase in emissions is possible as contaminated buildings and equipment are dismantled during site remediation.

\begin{tabular}{llll} 
Emission Category & $\begin{array}{l}\text { Amount } \\
\text { of Uranium } \\
\text { Emission }\end{array}$ & Sources & Comments \\
\hline Monitored Stacks & $<0.01 \mathrm{~kg}$ & Six stacks & $\begin{array}{l}\text { High efficiency filters used } \\
\text { to control emissions }\end{array}$ \\
\hline $\begin{array}{l}\text { Unmonitored Stacks } \\
\text { Vents }\end{array}$ & $1.1 \mathrm{~kg}$ & $\begin{array}{l}\text { Plant } 8 \text { vents, } \\
\text { laboratory hoods, } \\
\text { cooling towers, and } \\
\text { respirator washing } \\
\text { facility }\end{array}$ & $\begin{array}{l}\text { Estimated based on processes } \\
\text { and amount of material handled } \\
\text { in each facility }\end{array}$ \\
\hline $\begin{array}{l}\text { Fugitive/diffuse } \\
\text { Sources }\end{array}$ & $2.4 \mathrm{~kg}$ & $\begin{array}{l}\text { Plant } 4 \text { (D\&D) } \\
\text { Plants } 8 \text { and } 9 \\
\text { Waste Pit 5 }\end{array}$ & $\begin{array}{l}\text { Estimate based on ambient air } \\
\text { monitoring data and meteorological } \\
\text { conditions }\end{array}$
\end{tabular}

- AMS 10 through AMS 14 are located at schools and industries near the site and provide additional monitoring of emissions at these points.

- AMS 15 and AMS 16 were installed in 1989 to obtain additional background data. AMS 15 is located near the University of Cincinnati in Cincinnati, Ohio; AMS 16 is located in Miamitown, Ohio. In late 1994, road construction near AMS 15 required the monitor to be taken out of service. A replacement station (AMS 21) was installed on the Cincinnati State Technical College campus in May 1995.

- AMS 17 through AMS 20 were installed in 1992 to provide increased monitoring ofwaste pits' emissions. These monitors will provide valuable information on any pit emissions that occur during waste pit remediation.

At each AMS, air is drawn through a 20-cm-by-25-cm ( 8 inches by 10 inches) filter at a rate of about $1.3 \mathrm{~m}^{3}$ per minute (about $45 \mathrm{ft}^{3}$ per minute). Changes in flow rate over the sampling period are monitored and accounted for by inspecting charts that continuously record flow data.

Environmental monitoring personnel collect the filters from the AMSs for analysis at weekly intervals. Filters collected weekly from each AMS were combined to form two-week composite samples. Two-week composite samples are more costeffective than weekly analysis and free laboratory resources needed to support other monitoring efforts.

At the laboratory, technicians store the filters for at least three days following collection to allow naturally occurring, short-lived radionuclides (such as radon 
daughters) to decay. It is important to note that this holding period does not affect the amount of uranium on the filters. After the holding period, analysts heat the filters to $500^{\circ} \mathrm{C}\left(932^{\circ} \mathrm{F}\right)$ to remove organic matter. Finally, they dissolve these filters in acid and analyze the resulting solutions for uranium. A portion of each of these solutions is retained to prepare an annual composite, which is then analyzed for trace concentrations of radionuclides such as isotopes of radium, plutonium, and thorium.

DOE Order 5400.5, "Radiation Protection of the Public and the Environment," establishes guidelines for concentrations of radionuclides in air emissions. These guidelines, referred to as Derived Concentration Guidelines (DCGs), are concentrations of radionuclides that, under conditions of continuous exposure for one year by one exposure mode, would result in a dose of $100 \mathrm{mrem}$. The intent of the DCGs is to provide reference values that enable site personnel to review effluent data and determine if there is a potential to exceed the limits on dose to members of the public.

The average concentrations of uranium at the six fenceline AMSs (AMS 2 through AMS 7) were all less than $1 \%$ of the DOE guideline. Table 3 on page A-4 lists 1995 data for uranium concentrations. Figure 23 compares uranium concentrations at the air monitoring stations for 1991 through 1995.

Figure 23: Average Uranium Concentrations in Air, 1991 - 1995

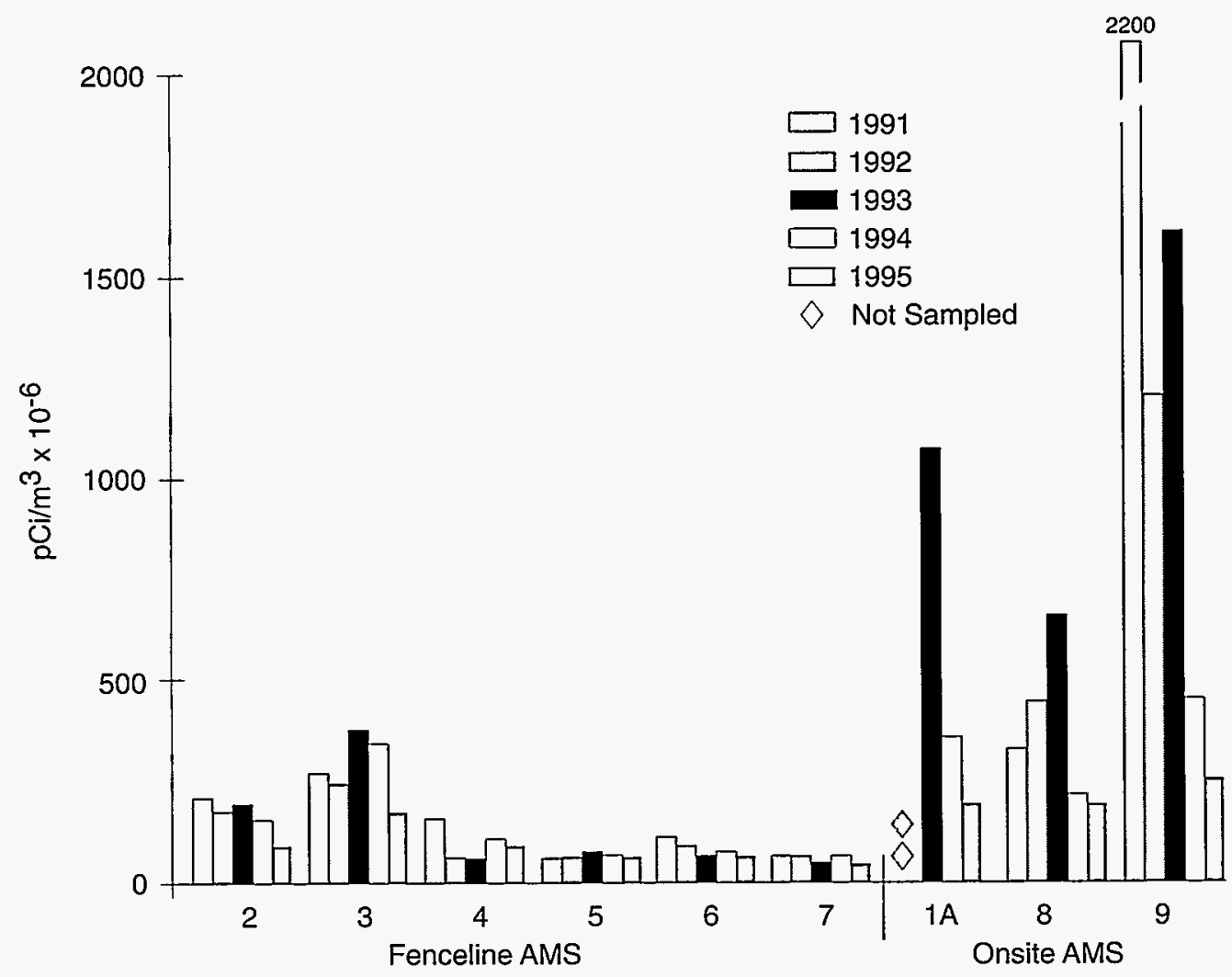


The data on the concentrations of trace radionuclides in 1995 are presented in Table 4 on pages A-5 through A-7. The results indicate concentrations of trace radionuclides at the onsite and fenceline locations are well below DOE guidelines. Concentrations of thorium-232 measured at the AMSs for 1991 through 1995 are presented in Figure 24. Thorium-232 and its decay products are stored in quantity at several locations onsite and are considered potential environmental contaminants.

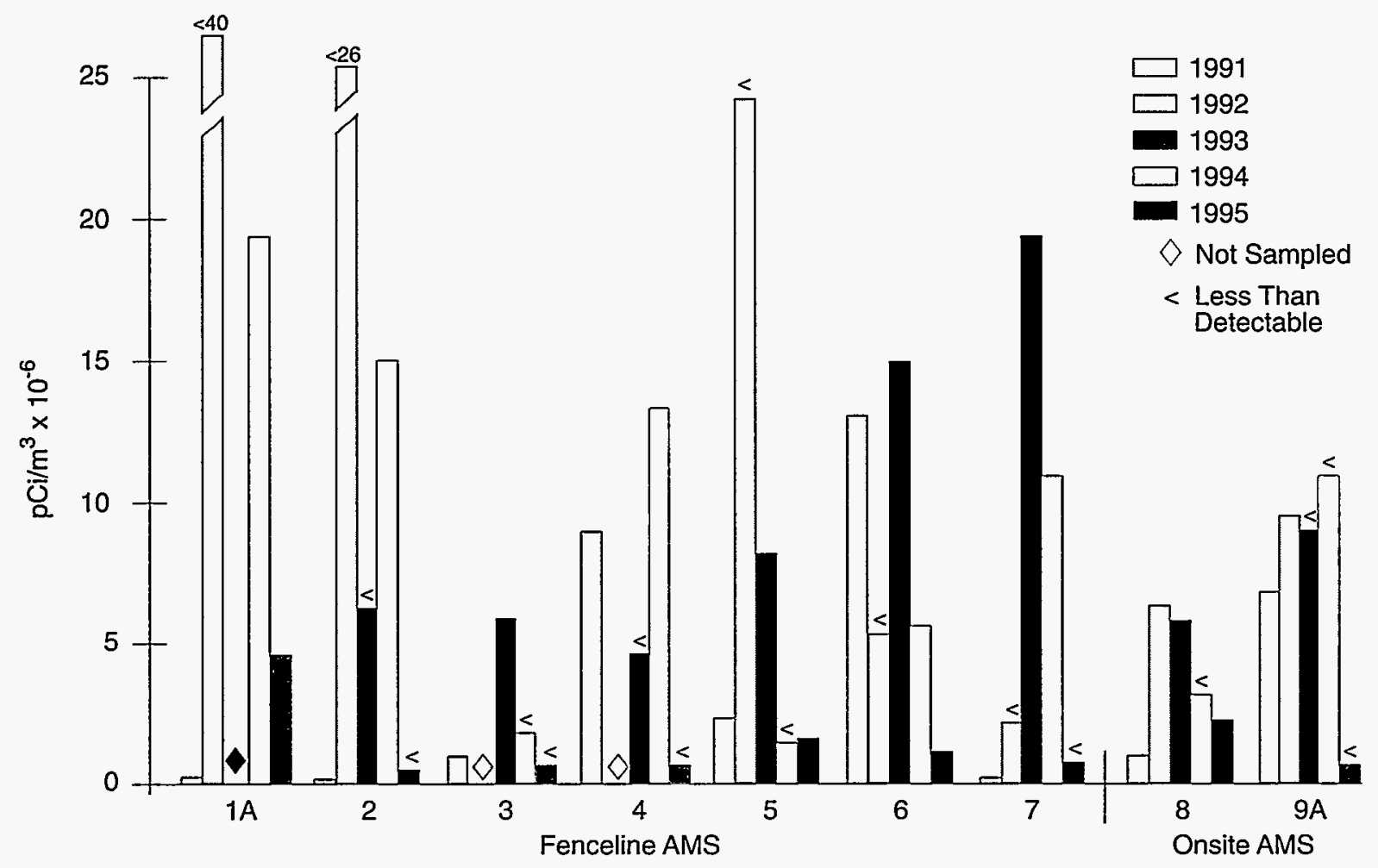

\section{LESS-THAN-DETECTABLE CONCENTRATIONS}

The less than symbol $(<)$ is used here when the concentration of thorium-232 in air could not be reliably measured in the sample which was analyzed. That is, the amount of thorium-232, if present at all in the sample, was below the minimum measurable concentration. Thus, a concentration of $<40 \mathrm{pCi} / \mathrm{m}^{3} \times 10^{-6}$ means the thorium concentration was less than $40 \mathrm{pCi} / \mathrm{m}^{3} \mathrm{x}$ $10^{-6}$ but actually could have been anywhere from 0.00 to $39.9 \mathrm{pCi} / \mathrm{m}^{3} \times 10^{-6}$. While it is difficult to accurately compare these data that do not have reliable measurements from year to year. it is important to keep in mind that even the highest concentrations shown here are well below the DOE limit. The DCG for thorium-232 in air is $7,000 \mathrm{pCi} / \mathrm{m}^{3} \times 10^{-6}$. 


\section{Monitoring Plant 1 \& Plant 4. Decontamination \& Decommissioning}

Prior to dismantling operations, four ambient air monitors were placed around Plant 1 and seven around Plant 4 . The monitoring effort is designed to verify that negligible amounts of uranium, thorium, and radium in the form of airborne contamination were released to the environment while dismantling the buildings, particularly during the removal of the exterior siding and demolition of the steel framework. The monitors also provided data for evaluating the effectiveness of these contamination control techniques. The Plant 4 monitors began operating in March, 1995, while the Plant 1 monitors went into operation in December, 1995. The monitors were similar to boundary air monitors in that air was drawn through a 20 -cm-by- $25-\mathrm{cm}$ ( 8 inches by 10 inches) filter at rate of about $1.3 \mathrm{~m}^{3}$ per minute (about $45 \mathrm{ft}^{3}$ per minute). Filters were changed weekly and analyzed for total uranium. The locations of the Plant 4 and Plant 1 monitors are shown in Figure 25, on the next page, and Figure 26, on page 88.

Through 1995, Plant 4, monitoring results indicated that airborne levels were relatively constant during the removal of equipment and duct work from the plant interior. Airborne uranium levels remained below the DOE guideline for uranium in air in the vicinity of Plant 4 . Table 5 on page A-8 is a summary of the weekly airborne uranium concentrations measured during the dismantling project.

Due to the December 1995 start of Plant 1 monitoring, only limited data are available for inclusion in this report. The 1995 and 1996 Plant 1 data will be reported in the 1996 Site Environmental Report.

\section{Soil Sampling for Uranium}

Site technicians take annual soil samples at air monitoring stations and off-site locations to evaluate changes in uranium concentrations that may occur through deposition, soil resuspension, or other mechanisms. (See Figure 27 on page 89 for sampling locations.) Uranium found in the soil may be naturally occurring, added by fertilizers, or a result of site operations. The amount of uranium naturally present in rocks and soils varies greatly. (See Figure 28 on page 90.) Uranium occurs naturally in many materials. The earth's crust, for example, contains about $2.7 \mathrm{pCi} / \mathrm{g}$ ( $4 \mathrm{ppm}$ ) of uranium. These ores are mostly uranium-238 but do contain about seven-tenths of one percent $(0.711 \%)$ of uranium-235. For example, out of twelve samples collected throughout Ohio, the range of uranium-238 concentrations was $0.76 \mathrm{pCi} / \mathrm{g}$ to $2.2 \mathrm{pCi} / \mathrm{g}^{25}$. Due to the natural abundance of the uranium235 isotope, the total radioactivity due to uranium is approximately double the uranium-238 value. (See Figure 28.) As a result, it is not possible to establish a single value for the background level of uranium and other minerals for areas such as those near the Fernald site. 
Figure 25: Plant 1 Monitoring Locations

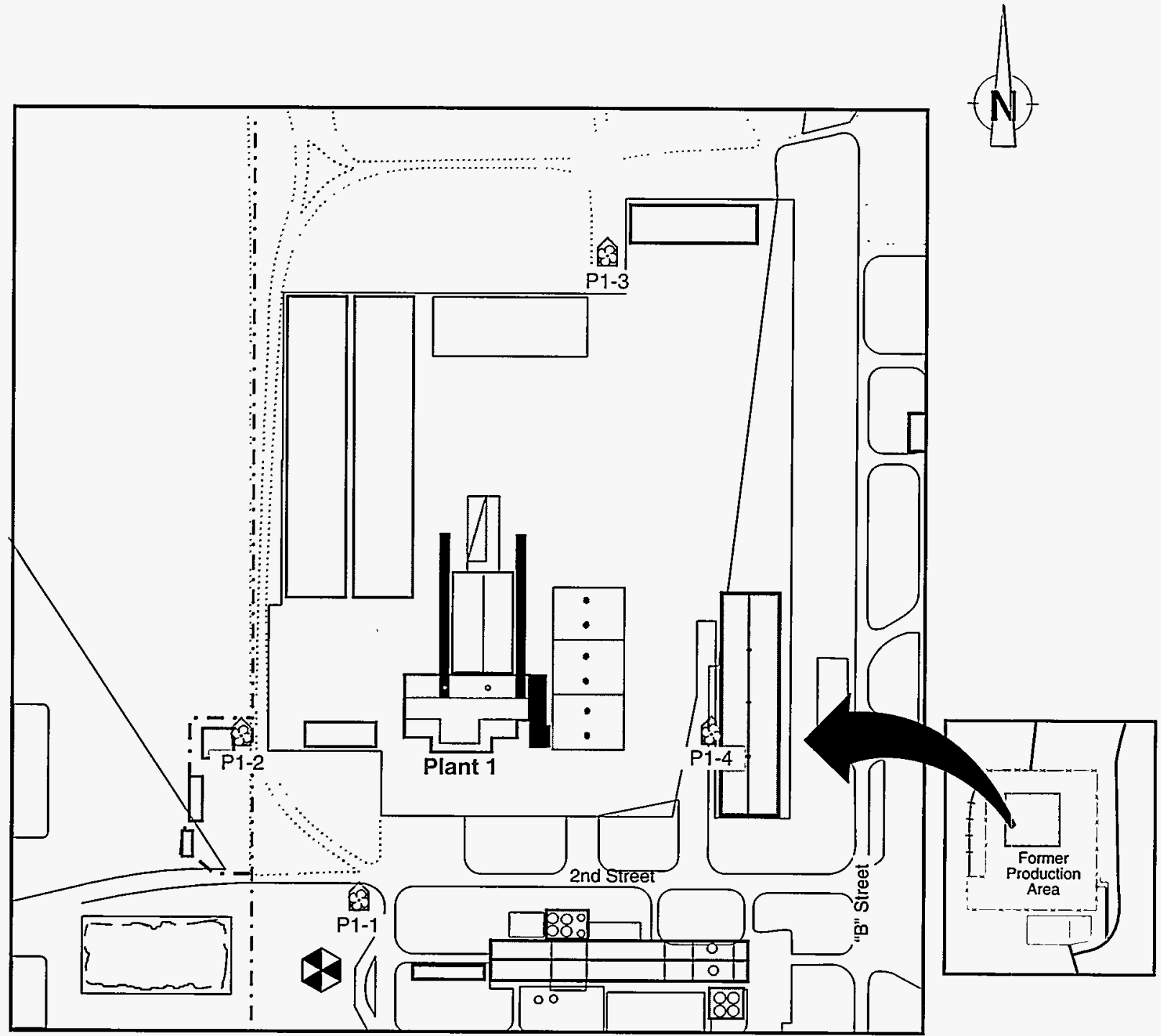

\section{LEGEND}

Plant 1 (P1) Air Monitoring Location 


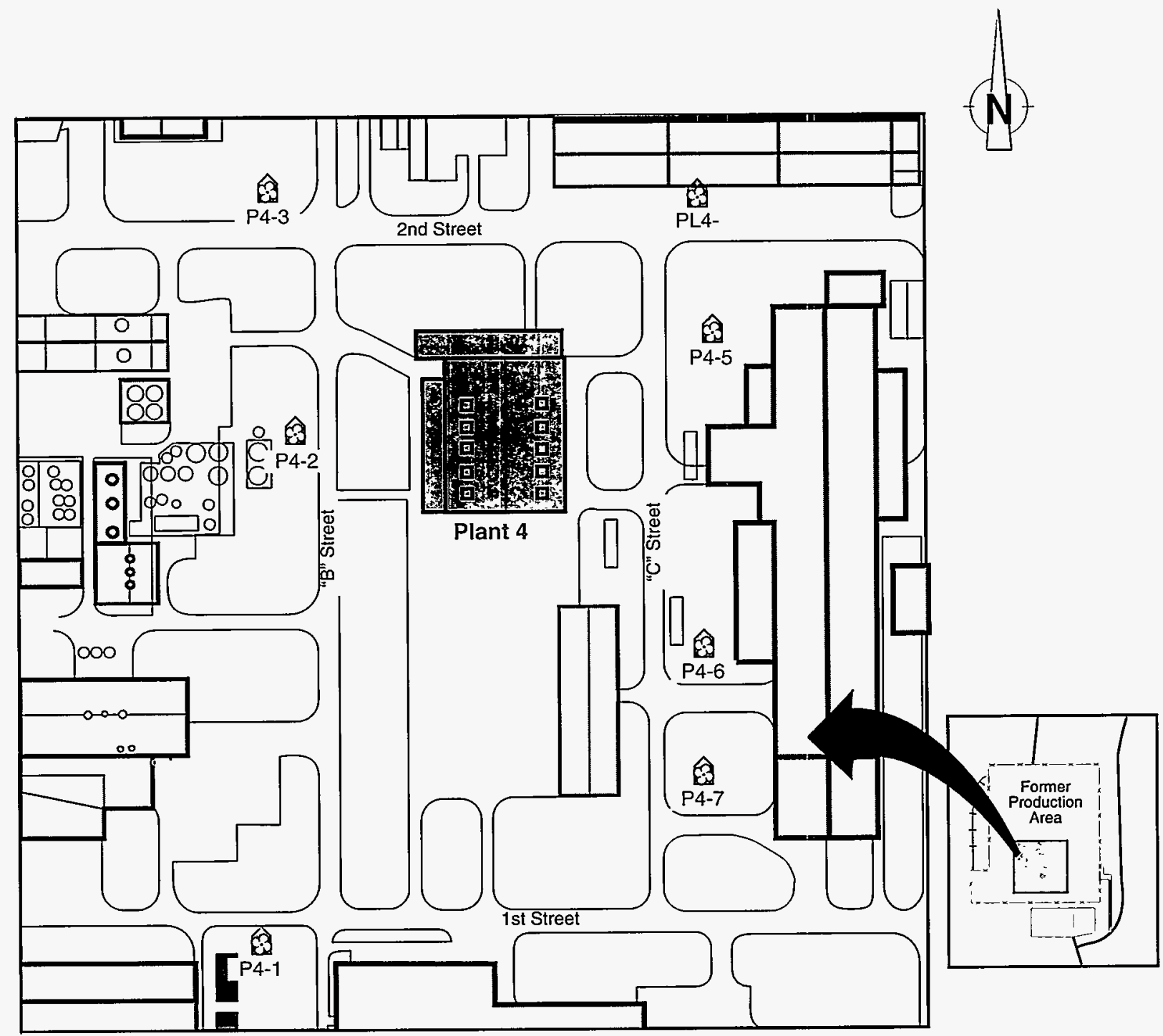

\section{LEGEND}

3 Plant 4 (P4) Air Monitoring Location 


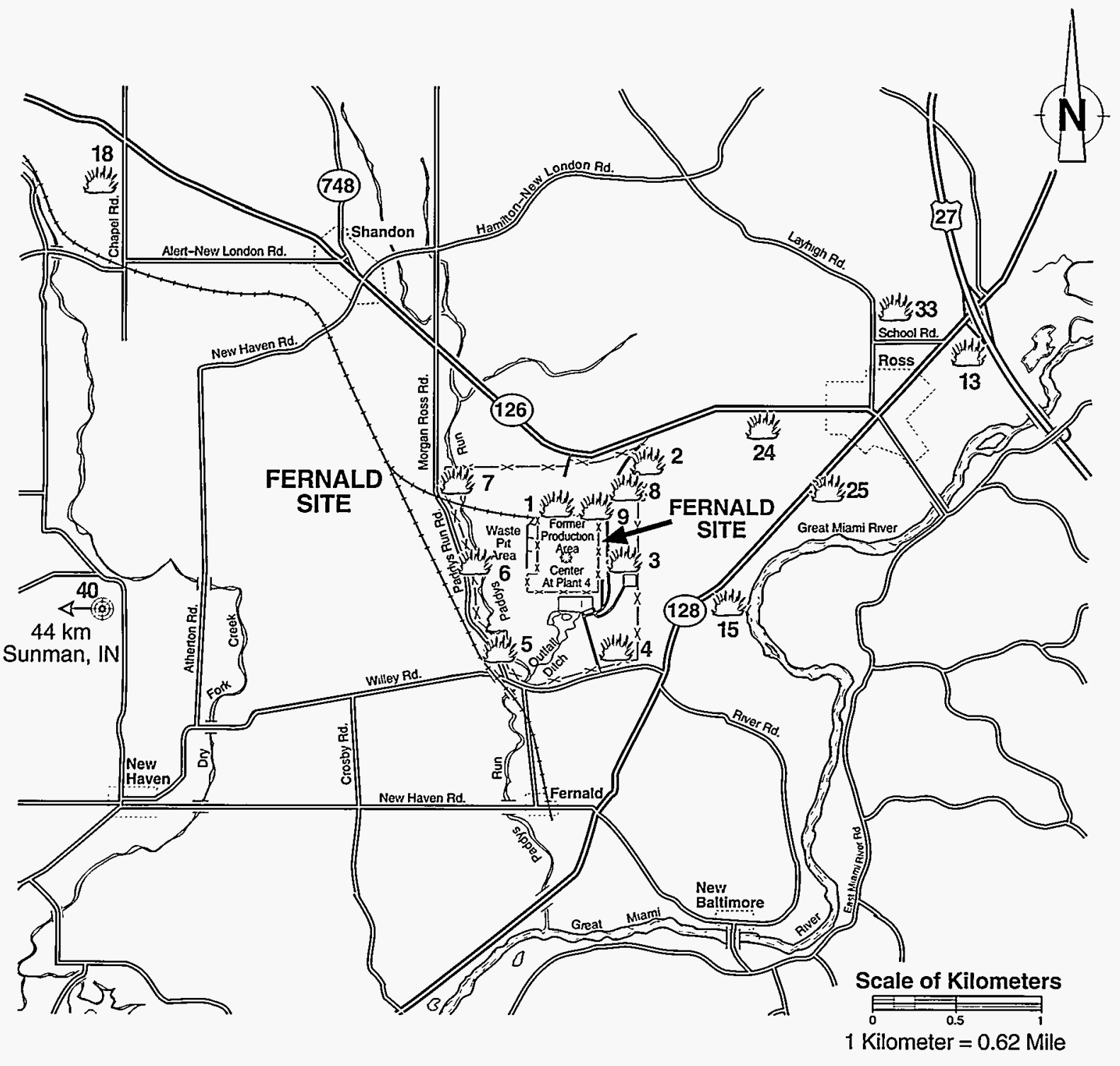

\section{LEGEND}

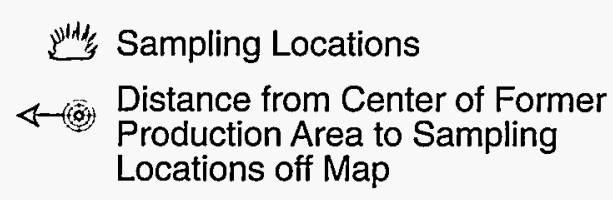

$\times \longrightarrow$ Plant Perimeter

$x-x-x$ Former Production Area Perimeter

Production Area to Sampling 


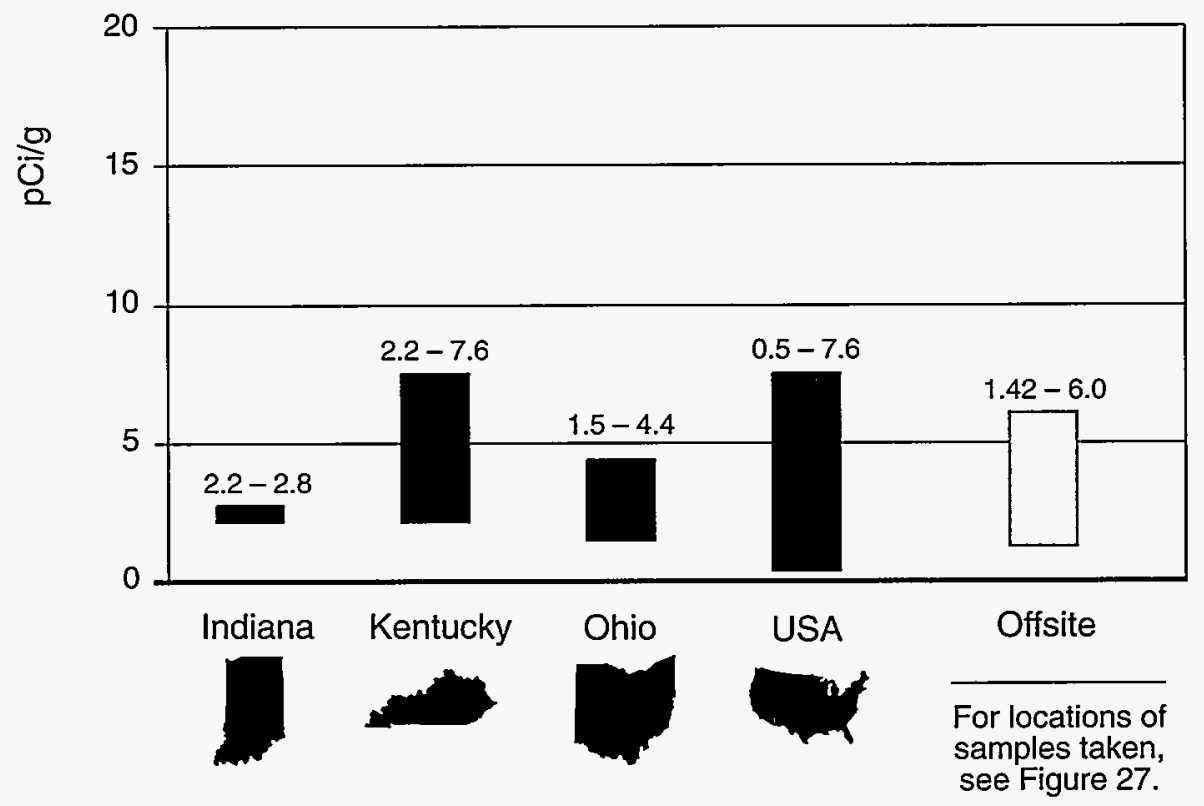

To better evaluate the uranium concentration in soil, the site conducted a study to determine the range of concentrations present in soil near the site. Soil samples were analyzed for a number of radionuclides; however, only uranium results are reported here. Results from this study show the mean uranium concentration is $2.1 \mathrm{pCi} / \mathrm{g}$ with an upper limit (95\% tolerance limit) of $2.8 \mathrm{pCi} / \mathrm{g}{ }^{23}$

As part of the soil sampling program, technicians collect 5-cm ( 2 inch)-deep cores of soil from undisturbed plots, excluding grass which is evaluated separately. Results show that uranium concentrations in soil samples taken onsite and the site fenceline ranged from $3.4 \mathrm{pCi} / \mathrm{g}$ at location 4 to $65 \mathrm{pCi} / \mathrm{g}$ at location 3 . The higher concentrations in onsite soil are indicative of the soil contamination known to exist, particularly in the northeast quadrant of the site. The uranium concentration in the offsite samples ranged from $1.42 \mathrm{pCi} / \mathrm{g}$ at sample location 13 to 6.0 $\mathrm{pCi} / \mathrm{g}$ at sample location 24 .

\section{Grass Sampling for Uranium}

Fernald site personnel analyze grass for uranium to determine if airborne emissions are affecting the uranium concentration in grass. Uranium contamination in vegetation may result from transfer of uranium from the soil through absorption by the plant, deposition of eroded soil, or from uranium deposited on the surface of the plant from the air. As a general rule, uranium is not selectively absorbed by plants because it serves no useful purpose in the plant's metabolic processes; however, small amounts of uranium may be absorbed through a plant's normal growth processes. 
Samples of grass were collected at the same locations as soil. Subsamples of grass are collected from the area around the soil sample location and then combined to form a composite sample. Each grass sample was a composite of at least three subsamples clipped near ground level. The composite samples each weighed about 500 grams $(1 \mathrm{lb})$. An offsite laboratory air-dried and then analyzed the samples for uranium.

Standards have not been established for uranium in grass; however, comparing results of samples collected at the site, and with the results of samples collected at offsite and outlying locations provides a means to evaluate the impact of site emissions on uranium concentration in grass.

In addition to soil sample results, Table 6 on page A-9 reports the following uranium concentrations in onsite, fenceline and off-site grass samples:

- Onsite and fenceline results for 1995 ranged from 0.015 to $0.60 \mathrm{pCi} / \mathrm{g}$ (dry weight), and

- Offsite results from 1995 ranged from 0.0043 to $0.13 \mathrm{pCi} / \mathrm{g}$ (dry weight).

The results indicate the 1995 uranium concentrations are within the range of historical concentrations and suggest that 1995 emissions have not affected uranium concentrations in grass.

\section{Produce Sampling for Uranium}

As mentioned in Chapter One, the Fernald site is surrounded by farmland. Locally grown sweet corn and tomatoes are two of the major crops sold from roadside stands within 3 miles of the site. Local residents also grow and sell beets, potatoes, apples, lettuce, pumpkins, cucumbers, and peppers.

With air emissions reduced to very low levels, the possibility of uranium contamination in produce from air deposition is also very low. While washing the produce before eating removes any surface contamination which may be present, some uranium may be taken up by plants through their root systems and incorporated into their edible portions. Uranium detected in produce may be uranium that is naturally occurring in the soil, added by fertilizers, or deposited on the ground from airborne emissions.

Technicians sample produce each year to determine if uranium concentrations in produce grown near the site (0-5 $\mathrm{km}$ or $0-3$ miles) are higher than concentrations in produce grown at distant locations (11-42 $\mathrm{km}$ or 7-26 miles) and are, therefore, a pathway of exposure from site emissions. (See Figure 29 on the next page for sampling locations.) The sample results are then used to estimate the potential dose to people from this component of the air pathway. (See Chapter Seven.)

The results of the produce and soil sampling program are reported in Table 7 on pages A-10 and A-11. In general, uranium concentrations varied greatly for each type of produce. A comparison between the average uranium concentrations in 
corn and tomatoes grown near the site with concentrations in corn and tomatoes grown distant from the site determined that the average concentrations were higher in corn and tomatoes grown distant from the site. These comparisons suggest that there is no substantial impact today from past or current Fernald site emissions on produce grown in the area.

Figure 29: Produce Sampling Locations

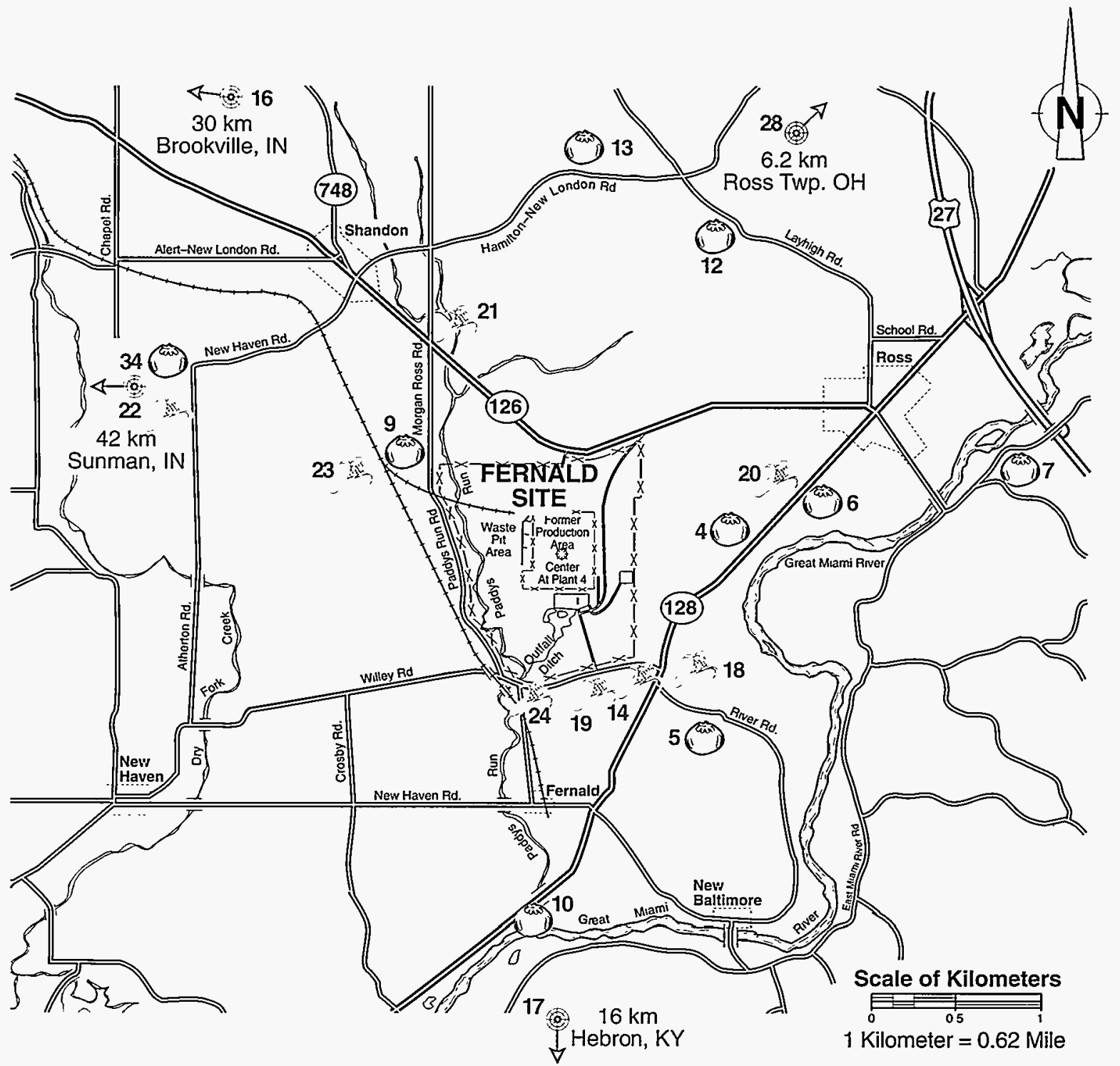

\section{LEGEND}

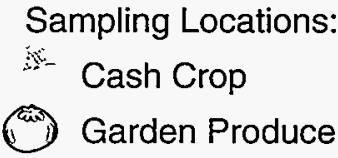

3309 $\times \longrightarrow$ Plant Perimeter

$x-x-x$ Former Production Area Perimeter

$\leftarrow$ Distance from Center of Former Production Area to Sampling Locations off Map 
Technicians also sample the soil in which the produce is grown. This sampling is in addition to the soil sampling described earlier and is conducted to compare uranium concentrations found in soil with the concentrations found in produce. To date, no strong correlation between uranium concentrations in soil and produce has been established. Uranium concentrations in the soil taken along with produce ranged from 1.22 to $3.85 \mathrm{pCi} / \mathrm{g}$ and were within the range of naturally occurring uranium concentrations in Ohio soils.

\section{Milk Sampling for Radionuclides}

Even though uranium is not normally concentrated in milk, the site monitored cows' milk as a component of the air pathway in response to public concerns about the dairy farm adjacent to the Fernald site. When the dairy farm ended milking operations in March 1995, the Fernald site ceased collecting milk samples. However, samples were collected only in January and February 1995, from both the local dairy and from a dairy in Indiana about $37 \mathrm{~km}$ (23 miles) west of the Fernald site. The milk samples were then frozen and shipped to an off-site laboratory for uranium analysis.

Table 8 on page A-12 presents the data from monthly milk sampling in 1995. The results show uranium concentrations in milk from the local dairy were comparable to the uranium concentrations measured in milk from the background (Indiana) dairy. The results also demonstrate that milk from the local dairy was not affected by site emissions.

\section{Beef Cattle Sampling for Radionuclides}

In late 1994, technicians collected beef tissue samples (bone, kidney, liver, and edible meat) from two cattle taken to a commercial meat processing plant. One was raised at a dairy farm adjacent to the site, the other at a background (Indiana) farm. Tissues were selected based on the deposition and retention of uranium in animal tissue and its significance as a food source. The samples were analyzed for isotopic uranium, isotopic thorium, isotopic plutonium, Sr-90 (strontium), Tc-99 (technetium), Cs-137 (cesium), and Ra-266 (radium).

The purpose of the sampling was to collect data on the radionuclide concentrations found in cattle raised in varying proximities to the site in order to evaluate the influence site emissions may have on locally raised cattle. At the time of sample collection, the dairy farm adjacent to the site was still in operation. In March 1995, the dairy was sold and is no longer in production. However, beef samples may continue to be collected on an as-needed basis to evaluate any potential impacts from remediation activities at the Fernald site.

Table 9 on page A-13 presents the results of the tissue sample analyses. Although the sampling was limited in the number of cattle sampled and most radionuclide concentrations were below the detectable level, the results suggest there is no substantial impact from past or current emissions on cattle raised in the local area. 


\section{Monitoring for Direct Radiation}

Direct radiation (X-rays, gamma rays, energetic beta particles, and neutrons) originates from sources such as cosmic radiation, naturally occurring radionuclides in soil, world-wide fallout from nuclear weapons testing, and radioactive materials at the Fernald site. The largest source of direct radiation at the site is the material stored in the K-65 silos. Gamma rays and X-rays are the dominant types of radiation emitted from the silos. Energetic beta particles and neutrons are not a significant component of direct radiation at the Fernald site because uranium, thorium, and their decay products do not emit this radiation at levels that create a public exposure concern.

Direct radiation levels at and around the site are continuously measured at 30 locations with thermoluminescent dosimeters (TLDs). TLDs absorb and store the energy of direct radiation within the thermoluminescent material. By heating the thermoluminescent material under controlled conditions, the stored energy is released as light, measured, and correlated to the amount of direct radiation. Figure 30 , located on the next page, shows the location of the TLD monitoring points. These monitoring points were selected based on the need to monitor the K-65 silos, the site boundary, and several off-site locations, including background locations. Three TLDs are placed at each monitoring location for a three-month period, yielding accurate and consistent quarterly measurements.

Results of direct radiation measurements for 1995 are provided in Table 10 on page A-14. Direct radiation fields vary from one location to another because of the differences in the terrestrial and cosmic components of natural background radiation. For example, varying concentrations of naturally occurring radium, thorium, and their decay products in soil result in different measured radiation levels. As expected, measurements of direct radiation indicate levels are higher in the area near the K-65 silos. These levels are $80 \%$ lower than radiation levels measured in 1991 prior to the addition of the bentonite layer within the K-65 silos. An estimated dose from direct radiation is provided in Chapter Seven.

\section{Monitoring for Nonradioactive Pollutants}

OEPA requires an estimate of emissions from the Boiler Plant as part of the site's effort to demonstrate compliance with the Clean Air Act. The site estimated the amount of nonradioactive pollutants including particulate matter (PM), sulfur dioxide $\left(\mathrm{SO}_{2}\right)$, nitrogen oxides $\left(\mathrm{NO}_{\mathrm{X}}\right)$, and carbon monoxide $(\mathrm{CO})$ and measured the shade, or density, of particulate emissions from the coal-fired boilers. Shade, or density, also called opacity, is a measure of how much light is blocked by particulates present in stack emissions.

In order to estimate $\mathrm{SO}_{2}$ emissions, scientists regularly determine the sulfur content and heat content of the coal. Using this information and the total amount of 


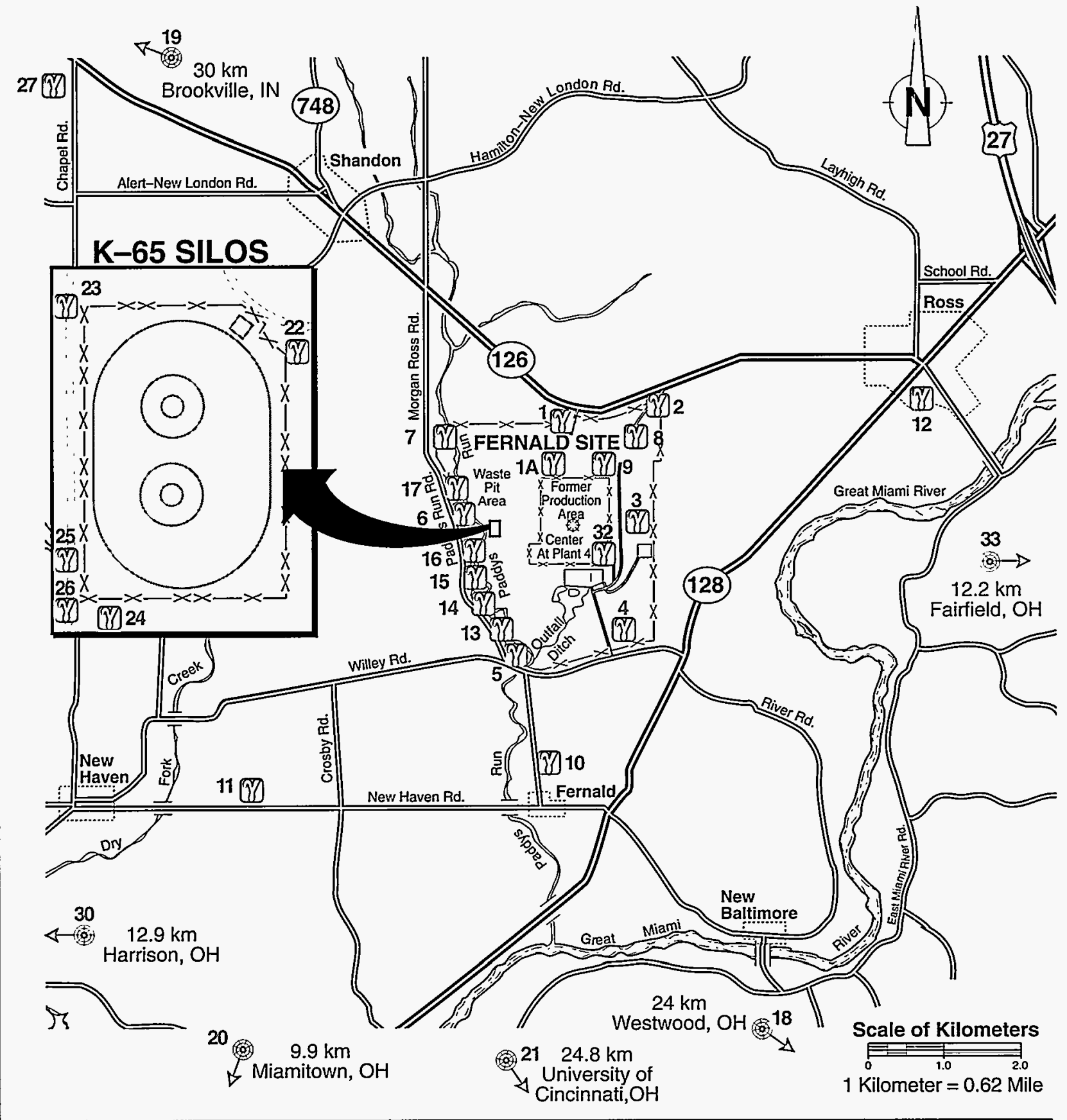

\section{LEGEND}

(19) Dosimeter Location

४(6) Distance from Center of

Former Production Area to

Dosimeter Locations off Map $x \longrightarrow \times$ Plant Perimeter

$x-x-x$ Former Production Area Perimeter 


\section{AIR EMISSIONS}

OEPA maintains an inventory system for actual air emissions from major point sources; the inventory is reported by the Department of Environmental Services - Air Quality Management (formerly the Southwestern Ohio Air Pollution Control Agency). The totals presented here are in kilograms.

\begin{tabular}{|c|c|c|c|c|c|}
\hline & \multirow{2}{*}{$\begin{array}{r}\text { Hamilton } \\
\text { County } \\
1994 \\
\end{array}$} & \multirow{2}{*}{$\begin{array}{r}\text { Butler } \\
\text { County } \\
1994 \\
\end{array}$} & \multirow{2}{*}{$\begin{array}{r}\text { Combined } \\
\text { Counties } \\
1994\end{array}$} & \multicolumn{2}{|c|}{$\begin{array}{l}\text { Fernald Site } \\
\text { Boiler Plant }\end{array}$} \\
\hline & & & & 1994 & 1995 \\
\hline Particulates & 2.1 million & 5.6 million & 7.7 million & 16,000 & 14,000 \\
\hline $\mathrm{SO}_{2}$ & 91 million & 15 million & 106 million & 290,000 & 298,000 \\
\hline $\mathrm{NO}_{x}$ & 31 million & 14 million & 45 million & 152,000 & 131,000 \\
\hline $\mathrm{CO}$ & 1.8 million & 25 million & 26.8 million & 54,000 & 48,000 \\
\hline
\end{tabular}

coal burned, the amount of $\mathrm{SO}_{2}$ emissions can be calculated. For 1995, $\mathrm{SO}_{2}$ emissions were calculated to be $298,000 \mathrm{~kg}$ $(657,000 \mathrm{lbs}) .{ }^{27}$ This was well below the allowable limit of 1.1 million $\mathrm{kg}(2.3$ million lbs) calculated from information in the Permit to Operate issued by OEPA.

The $\mathrm{NO}_{\mathrm{x}}$ emissions are estimated using USEPA-developed emission factors. $\mathrm{NO}_{\mathrm{x}}$ emissions for 1995 were estimated to be $131,000 \mathrm{~kg}(288,000 \mathrm{lbs})$. To date, OEPA has not set $\mathrm{NO}_{\mathrm{x}}$ or $\mathrm{CO}$ limits for Fernald site industrial processes. Carbon monoxide emissions were estimated using USEPA-developed emission factors. Carbon monoxide emissions in 1995 were estimated to be $48,000 \mathrm{~kg}(105,000 \mathrm{lbs})$.

Electrostatic precipitators reduce particulate emissions from the Boiler Plant. These emissions were estimated to be $14,000 \mathrm{~kg}$ (31,000 lbs) for 1995. This estimate was based on emission factors developed from stack testing in 1988. The opacity of the emissions from the two site coal-fired boilers was continuously monitored by instruments designed for that purpose. During 1995, the boilers operated 9,975 hours, and 99,750 measurements were made and recorded at six-minute intervals. A total of 34 excursions failed to meet the opacity standard. These excursions were brief, typically less than 18 minutes in length, and associated with boiler start up or load changes.

In addition to directly affecting concentrations of contaminants in soil, grass, and other media discussed in this chapter, the air pathway can indirectly influence contaminant concentrations in the liquid pathway. Stormwater runoff is one way materials released in the air can be transported into surface water such as Paddys Run. Eventually, these contaminants may affect groundwater quality as well. The next two chapters describe the monitoring program for the liquid pathways at the Fernald site, beginning with effluent and surface water monitoring in Chapter Five. 


\section{LIQUID PATHWAY: EFFLUENT AND SURFACE WATER MONITORING}

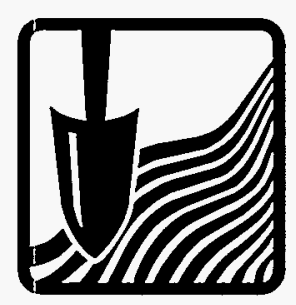




\section{Liquid Pathway: Effluent and Surface W/ater Monitoring}

The Fernald site continues to investigate the effects of past and current operations on the liquid pathway, the second major pathway for potential human exposure. Contaminants are able to leave the site through regulated liquid effluents and uncontrolled stormwater runoff. Surface water runoff can enter the aquifer and influence groundwater quality. This chapter discusses the sampling methodologies and results used to evaluate the site's effluents. It also discusses any impacts from the site on the Great Miami River and Paddys Run.

\section{Results in Brief: 1995 Liquid Pathway: Effluent and Surface Water}

NPDES - During 1995, out of 2,367 NPDES compliance opportunities there were 37 violations of NPDES limits.

Effluent-Approximately $179 \mathrm{~kg}$ (394 lbs) of uranium were discharged to the Great Miami River during 1995. Approximately $131 \mathrm{~kg}$ (289 Ibs) of uranium reached Paddys Run through uncontrolled stormwater runoff during 1995.

Surface W/ater - The liquid effluent discharged to the Great Miami River resulted in a down-river uranium concentration higher than the up-river concentration. However, the down-river concentrations were consistent with 1994 data. Paddys Run continued to show effects of stormwater runoff from the site. The average uranium concentration at the nearest off-site sampling location was higher than in 1994, 1.05\% of the DOE guideline for drinking water, which is used for comparison purposes only.

Sediment-Radionuclide concentrations in the Great Miami River and Paddys Run sediment for 1995 were consistent with previous years' data and did not indicate a build-up of radioactive pollutants in the sediment.

Fish - In 1995, fish caught in the Great Miami River downstream of the site's effluent line showed uranium concentrations no greater than concentrations found in upstream fish. 


\section{Monitoring for Radioactive Pollutants}

The first section of this chapter centers on the radioactive pollutants and begins with an examination of the liquid effluent sampling and analysis program. A discussion of the river and creek surface water sampling program follows. The Fernald site conducts these programs because radionuclides in the regulated liquid effluent and in uncontrolled stormwater runoff may be a source of radiation exposure to the public.

The Fernald site limits the discharge of nonradioactive pollutants in liquid effluent to meet the requirements for a National Pollutant Discharge Elimination System (NPDES) permit. This permit system falls under OEPA jurisdiction and regulates the discharge of nonradioactive pollutants to Ohio waters. The permit specifies sampling locations, sampling and reporting schedules, discharge limits, and other restrictions on site effluents discharged to both the Great Miami River and Paddys Run. Table 11 on pages A-15 through A-17 contains the NPDES monitoring data for 1995. A diagram of all monitoring locations is shown in Figure 35 on page 105. Out of 2,367 NPDES compliance opportunities for 1995,37 were judged out of compliance with the limits. This represents an in compliance factor of $98.4 \%$.

The NPDES permit for the Fernald site was renewed by OEPA and implemented on November 1, 1995. In summary, the new permit eliminated sampling and monitoring at the Biodenitrification/Effluent Treatment System and the General Sump, added four sampling and monitoring locations for stormwater which eventually discharges to Paddys Run, and requires biomonitoring of the total effluent and the river downstream of our discharge point. As renewed, this permit expires March 31, 1998. (See Table 12 on page A-18 and Table 14 on page A-21.)

\section{Effluent Sampling for Radionuclides}

This section of the chapter examines the liquid effluent sampling and analysis program. The Fernald site conducts this program because radionuclides in both regulated liquid effluent and uncontrolled stormwater runoff are a potential source of radiation exposure to the public.

The Advanced Wastewater Treatment Facility began operating in January 1995, providing "the best available technology" treatment for both stormwater and process wastewater before being discharged to the Great Miami River. Similar technology has been used at the Stormwater Retention Basin (SWRB) with an Interim Advanced Wastewater Treatment (IAWWT) facility and another Interim Advanced Wastewater Treatment system that extracted uranium from wastewater discharged from the Biodenitrification Surge Lagoon (BSL).

The site manages site-generated liquid effluents by monitoring and treating the effluents as necessary before they eventually enter Manhole-176B, where efflu- 


\section{SEE ADDENDUM}

ents combine before flowing into the Great Miami River. On an average day during 1995, about 2.2 billion liters (570 million gallons) of Great Miami River water flowed past the site's effluent line. ${ }^{8}$ The site discharged an average of 9.4 million liters ( 2.5 million gallons) of effluent, 8.3 million liters ( 2.2 million gallons) from the South Plume, and 1.2 million liters ( 0.32 million gallons) from Manhole-175/ Parshall Flume, into the river each day. Therefore, on average, each liter of effluent discharged was combined with about 234 liters of river water (1 gallon of effluent combined with 62 gallons of river water).

\section{Sources of Effluent During 1995}

The site's liquid effluents have been categorized into 11 basic sources. Any sitegenerated liquid effluent is monitored for contamination; if necessary, it is treated before being discharged to the Great Miami River. Figure 31 on the next page illustrates the effluent flow and treatment points.

The first two sources are the controlled contaminated stormwater runoffs from the waste pit area and the controlled contaminated stormwater runoffs from the perimeter of the waste pits area. Effluent from these sources are collected and pumped to the Biodenitrification Surge Lagoon (BSL).

The third source of liquid effluent is perched groundwater. This effluent is treated for volatile organic compounds (VOCs) by the Plant 8 Granular Activated Carbon System.

The fourth source of effluent is the combination of sanitary sewage and wastewater from the laundry. This effluent is processed at the Sewage Treatment Plant to remove biological contaminants. Afterward, the effluent is sent to Manhole-175, and sewage sludge is trucked to the Plant 8 treatment system, where it is dewatered. The resulting liquid is sent to the contaminated side of the General Sump, and the dewatered sludge is drummed and stored as low-level radioactive waste.

The combination of plant effluent and pad stormwater makes up the fifth source of effluent and is sent directly to the contaminated side of the General Sump. All liquids sent directly to the contaminated side of the General Sump are combined. If treatment for uranium and heavy metals is necessary, the combined liquid is sent to the Plant 8 treatment system.

If treatment is not required, the combined liquid is sent to the BSL. The effluent is treated in the Biodenitrification Facility (BDN) towers to reduce nitrates. From there, the liquid flows through the BDN effluent treatment system, after which the combined treated effluent flows to the AWWT for uranium removal prior to discharge through Manhole-176B.

The sixth through the eighth sources of effluent are all collected in the noncontaminated side of the General Sump. Boiler plant blowdown and coal pile 


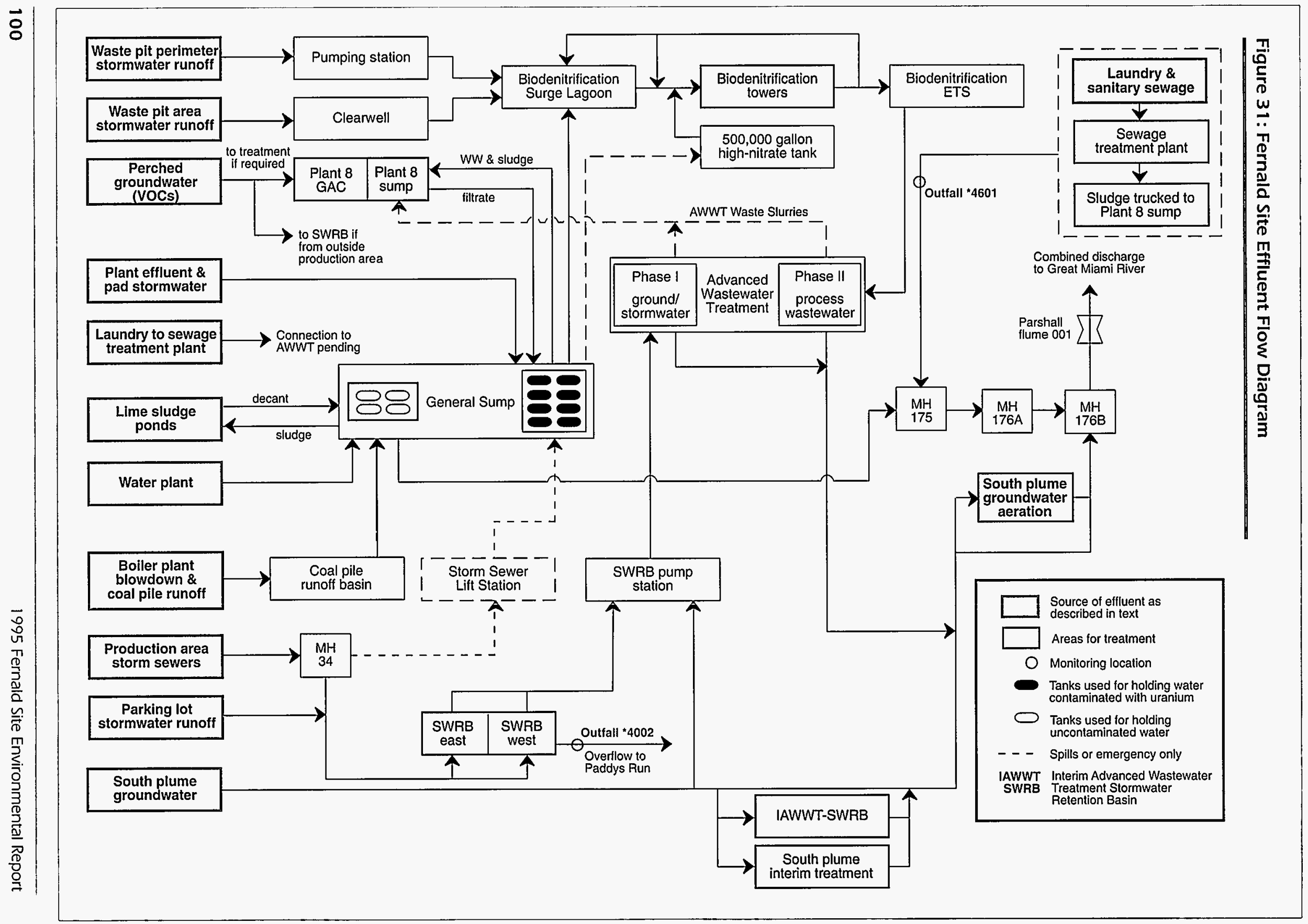


runoff are collected in the Coal Pile Runoff Basin and, after clarification, are sent to the noncontaminated side of the General Sump. Water plant effluent and lime sludge pond decants are sent directly to the noncontaminated side of the General Sump. After settling, the liquid in the noncontaminated side of the General Sump is sent to either the BSL or Manhole-175, and the sludge is sent to the North Lime Sludge Pond.

The production area storm sewers and parking lot runoff (see shaded areas of Figure 32) collect rain, making the ninth and tenth sources of effluent. Stormwater runoff from the former production area is collected by a network of storm sewers that converge at Manhole-34. Normally all runoff is directed to the SWRB; but if needed, effluent can be pumped to Manhole-175 from the Storm Sewer Lift Station. Stormwater collected in the SWRB is allowed to settle before being pumped to the AWWT for uanium removal.From there the effluent is sent to Manhole-176B.

The eleventh and final source of effluent is generated from the pumping of the South Plume groundwater. The South Plume groundwater is monitored before being pumped to the South Plume Aeration Building, where it can be aerated if needed and sent to Manhole-176B. Groundwater from the South Plume is pumped back onsite before it is discharged to the Great Miami River. Once onsite, it is considered a source of effluent. The effluents generated from the South Plume groundwater are monitored separately from the effluents generated onsite. After being monitored, all effluents are combined at Manhole-176B before being discharged to the river.

The site monitors any discharges to Paddys Run that occur from overflow of the SWRB. In 1995, the SWRB overflows were attributed to heavy rainfall recorded in May and August. The SWRB overflowed on May 18 (1,657,000 gallons), May 19 (428,000 gallons), and August 6 (1,600,000 gallons). Since the SWRB began operating in 1986, the amount of uranium entering the Storm Sewer Outfall Ditch (SSOD) has been substantially reduced. (See Table 14 on page A-21.)

\section{Sampling Methodologies}

Mixed effluent, described above, was sampled at Manhole-175 (until November 1995, when sampling was transferred to the Parshall Flume) and SP3 by flow-proportional samplers (continuous operating devices that collect a sample proportional to the volume of effluent flow). After every 24 hours of operation, the collected liquid is removed from the automatic sampler to provide a daily flow-weighted sample of the effluent. (See Figure 33 on page 103.)

Scientists analyze a portion of each daily sample of effluent to determine the amount of total uranium discharged to the Great Miami River. In addition, monthly composites were formed by combining the month's daily samples at each location. The monthly composites were analyzed for four uranium isotopes and 10 other radionuclides. Composites, rather than daily samples, were analyzed because many of radionuclides are typically present in only trace amounts, and it is 
Figure 32: Area of Controlled Stormwater Runoff

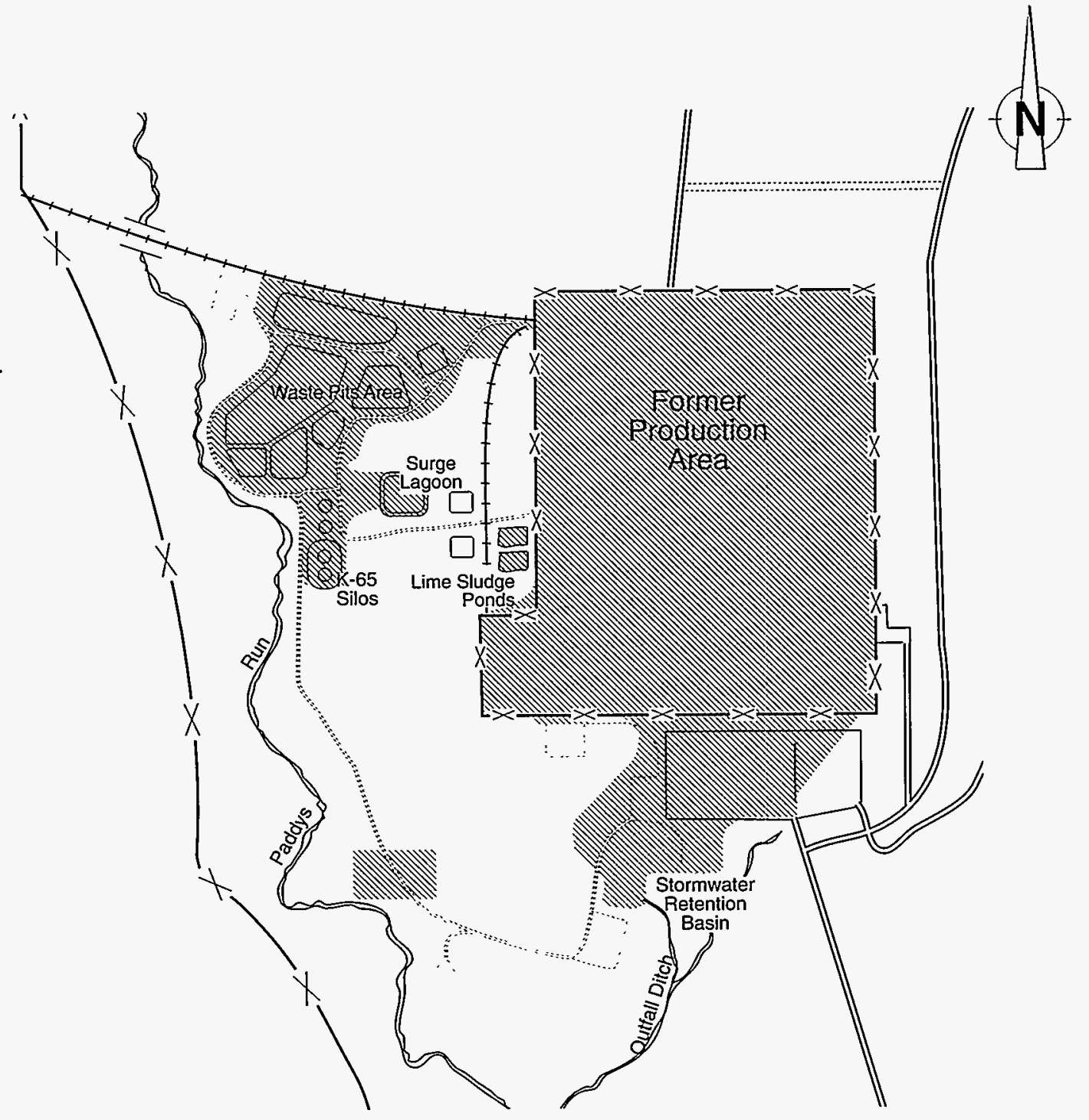

Scale of Meters

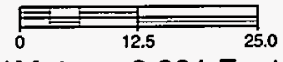

1 Meter $=3.281$ Feet

\section{LEGEND}

Shaded Areas are Collected and

Eventually Discharged to the

Great Miami River $x \longrightarrow \times$ Plant Perimeter
$x-x-\times$ Former Production Area Perimeter 
Figure 33: Continuous Sampling
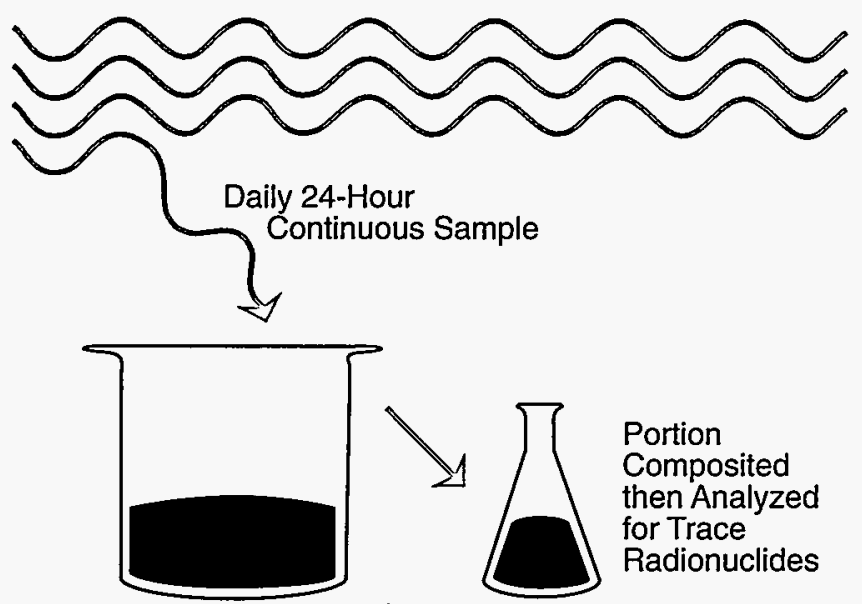

Portion

Composited

then Analyzed

for Trace

Radionuclides
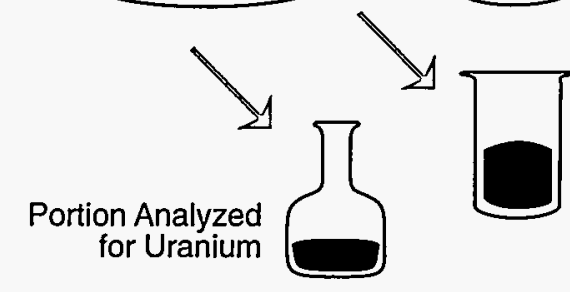

Portion

Analyzed for Nonradiological Contaminants neither practical nor cost-effective to perform more frequent analyses.

\section{Results of Laboratory Analyses}

Table 12 on page A-18 summarizes the radionuclide analysis of the liquid effluent discharged to the Great Miami River. The table shows the total radionuclide activity (in Curies) in effluents and the average radionuclide concentration (in $\mathrm{pCi} / \mathrm{L}$ ) for 1995.

During 1995, a total of $179 \mathrm{~kg}$ (394 lbs) of uranium was discharged to the Great Miami River. This was a decrease of $49 \%$ in comparison to the $351 \mathrm{~kg}$ (772 $\mathrm{lbs}$ ) of uranium discharged to the river during 1994. The uranium contained in all effluents discharged from the site also decreased from an estimated $461 \mathrm{~kg}$ $(1,013 \mathrm{lbs})$ in 1994 to an estimated 310

$\mathrm{kg}$ (682 lbs) in 1995. This decrease may be attributed to additional treatment capacity provided by the AWWT. Comparisons of uranium discharges to the Great

Miami River between 1991 and 1995

Figure 34: Total Uranium Discharged from the Site, $1991-1995$

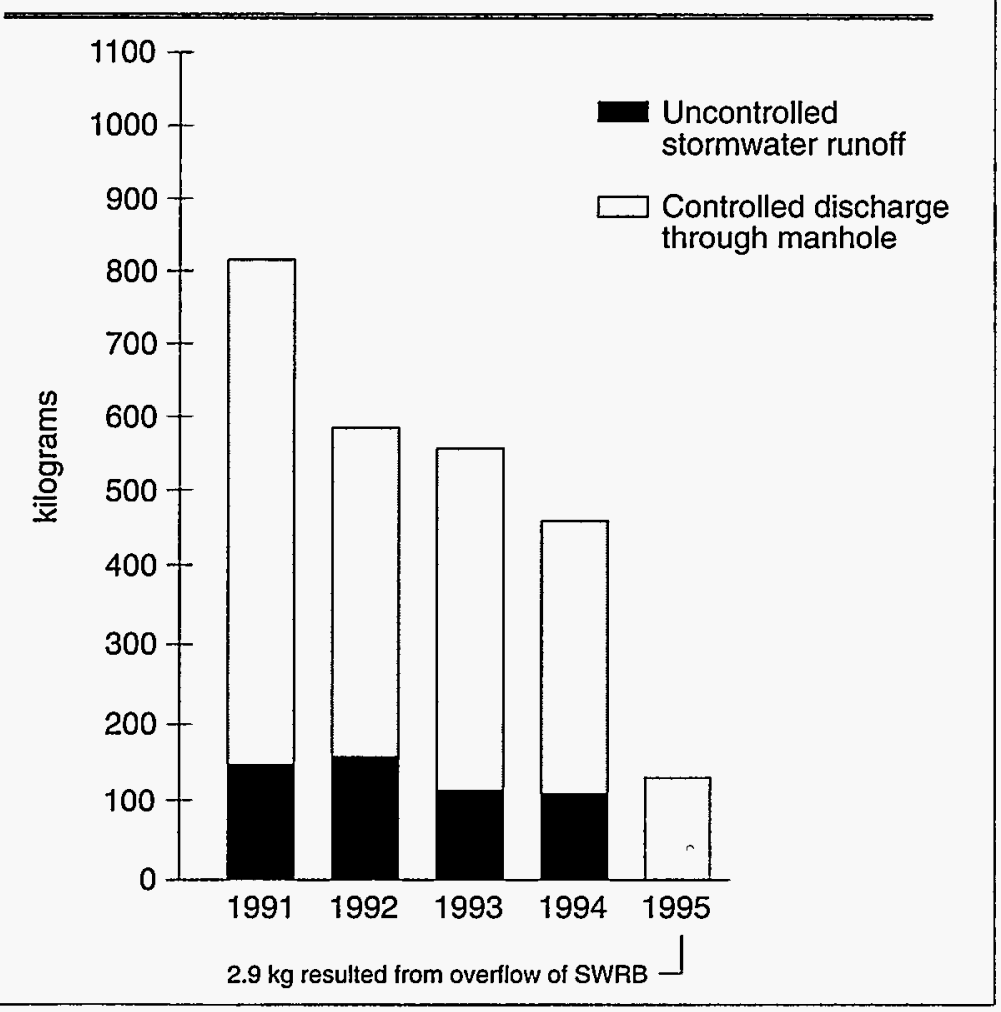

are shown in Figure 34. Additionally, all target analytes for sampling locations were within acceptable limits.

The average concentration of each radionuclide is compared to the Derived Concentration Guideline (DCG) or standard. DOE orders state that a dose must be estimated based on all of the radionuclides present in the effluent. The annual average percentages of the DCG for each radionuclide, when added together (Manhole-175 and SP3 combined), must not exceed $100 \%$. When the total is above $100 \%$, the site is required to use the "best available technology" to reduce radionuclide concentrations in its effluent. The DCG was not exceeded in 1995. 
An estimate of uranium in uncontrolled stormwater runoff is reported to USEPA. Fernald personnel have developed a general estimate of $2.8 \mathrm{~kg}(6.3 \mathrm{lbs})$ of uranium in the runoff to Paddys Run for every inch of rain. For 1995, the estimate of uranium in stormwater runoff to Paddys Run was reported as $131 \mathrm{~kg}$ (289 lbs). This estimate was based on the amount of precipitation recorded by the site meteorological system ( $114.8 \mathrm{~cm}$ or 45.2 inches).

\section{Surface Water Sampling for Radionuclides}

The site's surface water sampling program measures the effects of two potential sources of contamination on local waterways: the discharge of liquid effluents into the Great Miami River and the uncontrolled stormwater runoff into Paddys Run. The SWRB overflowed during heavy rainfall on May $18(1,657,000$ gallons), May 19 (428,000 gallons), and August $6(1,600,000$ gallons) in 1995, which resulted in a discharge of $2.9 \mathrm{~kg}$ of uranium to Paddys Run. Figure 32 on page 102 shows the area of controlled stormwater runoff.

\section{Sampling Methodologies}

During 1995, surface water was sampled at the following locations identified in Figure 35:

- Three locations along the Great Miami River (W1 - upstream from the effluent discharge, W3, and W4);

- Five onsite locations along Paddys Run (W9, W10-US, W10, W10-DS, and W11);

- One location along the drainage ditch originating near the Pilot Plant (W10-DD); and

- Three offsite locations along Paddys Run (W5 - upstream from the site, W7, and W8).

Each week, the onsite laboratory analyzed one of the daily samples from each river sampling location for total uranium. Portions of the daily samples collected along the Great Miami River were combined to form weekly and monthly composites for each location, which were then analyzed for radium-226 and radium228. Six-month composites, taken from the individual monthly composites, were analyzed for cesium-137, strontium-90, and technetium-99.

Weekly grab samples were collected at the five onsite locations along Paddys Run, one location along the drainage ditch, two locations upstream (north) of the site, and two locations downstream (south) of the site. All samples collected along Paddys Run were analyzed weekly for total uranium. Two-month composites of weekly samples from W5 were analyzed for isotopic radium, as were monthly composites at W7 (or W8 if there was not enough water at W7). On many occasions, there was an insufficient quantity of water present in Paddys Run at one or more location to collect samples. 


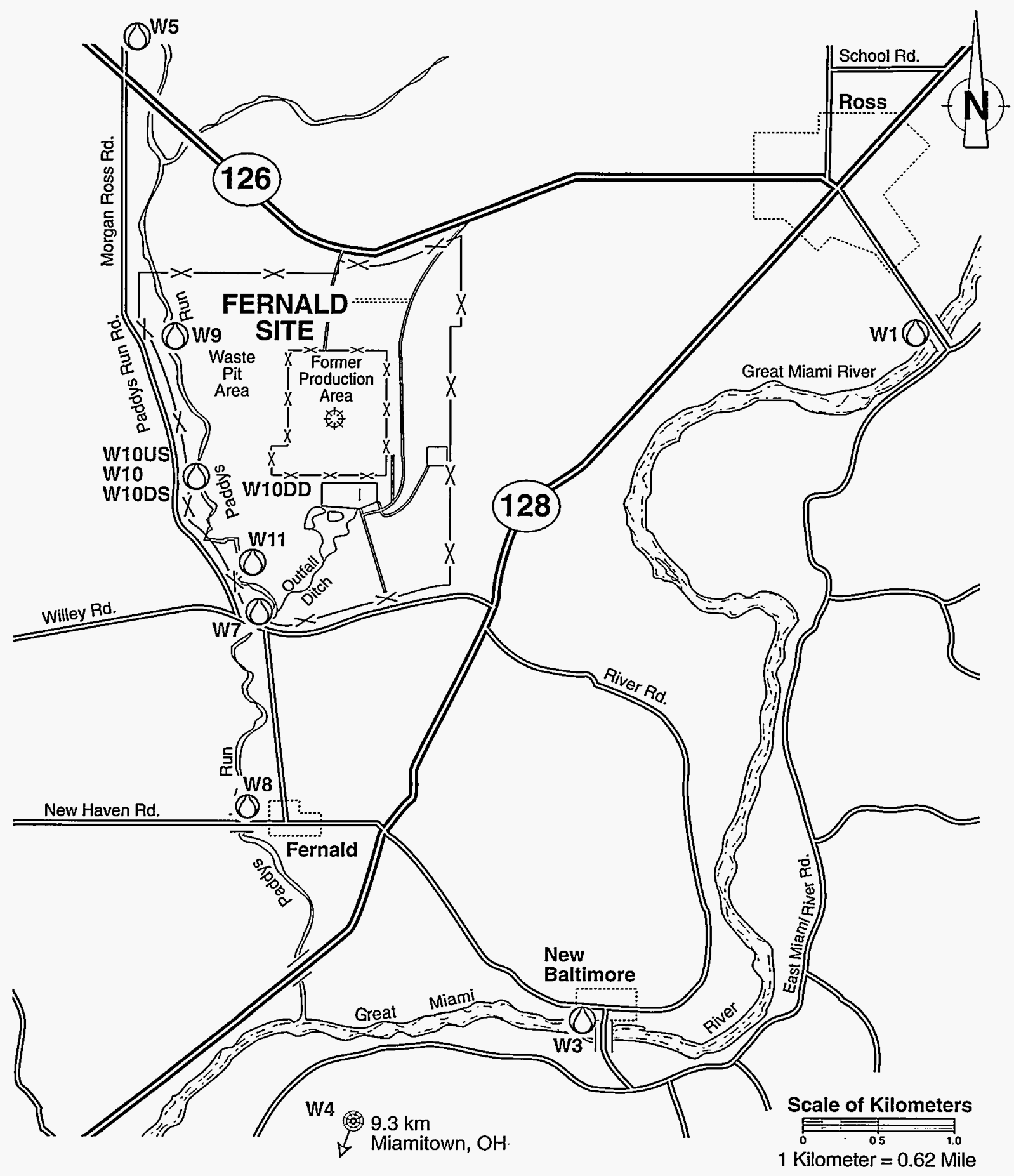

\section{LEGEND}

Sampling Location

४(9) Distance from Center of Former Production Area to Sampling Locations off Map $>\longrightarrow>$ Plant Perimeter

$x-\times-x$ Former Production Area Perimeter 
Uranium concentrations at $\mathrm{W} 10$ have varied greatly. This may be due to the fact that uranium concentrations in surface water are not directly comparable over time due to different states of dilution as a result of varying precipitation and flow rates. Consequently, representative samples cannot always be obtained because the effluent from the drainage ditch often does not have sufficient time to completely mix with the water in Paddys Run to provide a homogeneous liquid for sampling. To account for this problem, three sampling locations (W10-US - upstream of $\mathrm{W} 10$ and near the K-65 silos, W10-DD - along the drainage ditch, and W10-DS - just downstream of W10) were sampled.

\section{Results of Laboratory Analyses}

The radionuclide concentrations found in surface water samples collected during 1995 are summarized in Table 13 on pages A-19 and A-20. The data indicate that differences in total uranium concentrations in the Great Miami River were very small. Average uranium concentrations at $\mathrm{W} 3(1.1 \mathrm{pCi} / \mathrm{L})$ and $\mathrm{W} 4(1.2$

$\mathrm{pCi} / \mathrm{L}$ ) were well below the $\mathrm{DOE}$ guideline for drinking water (used for compari-

Figure 36: Average Uranium Concentrations in Surface W/ater, 1991 - 1995

Great Miami River Locations

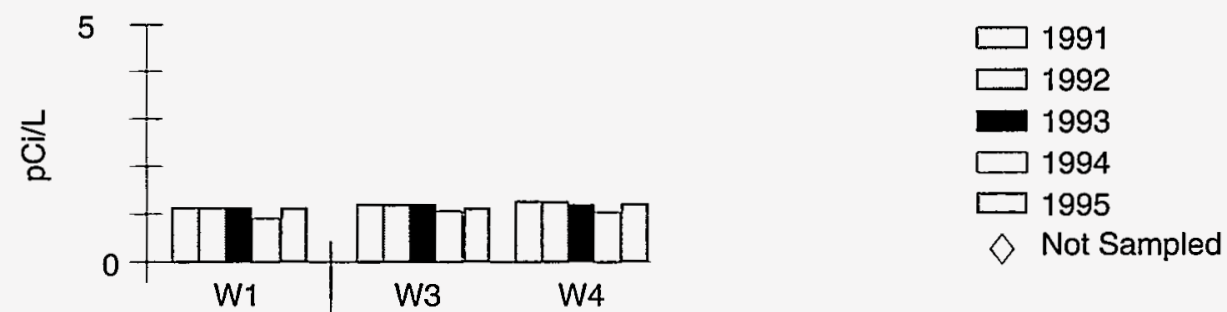

Upstream Downstream

Paddys Run Locations

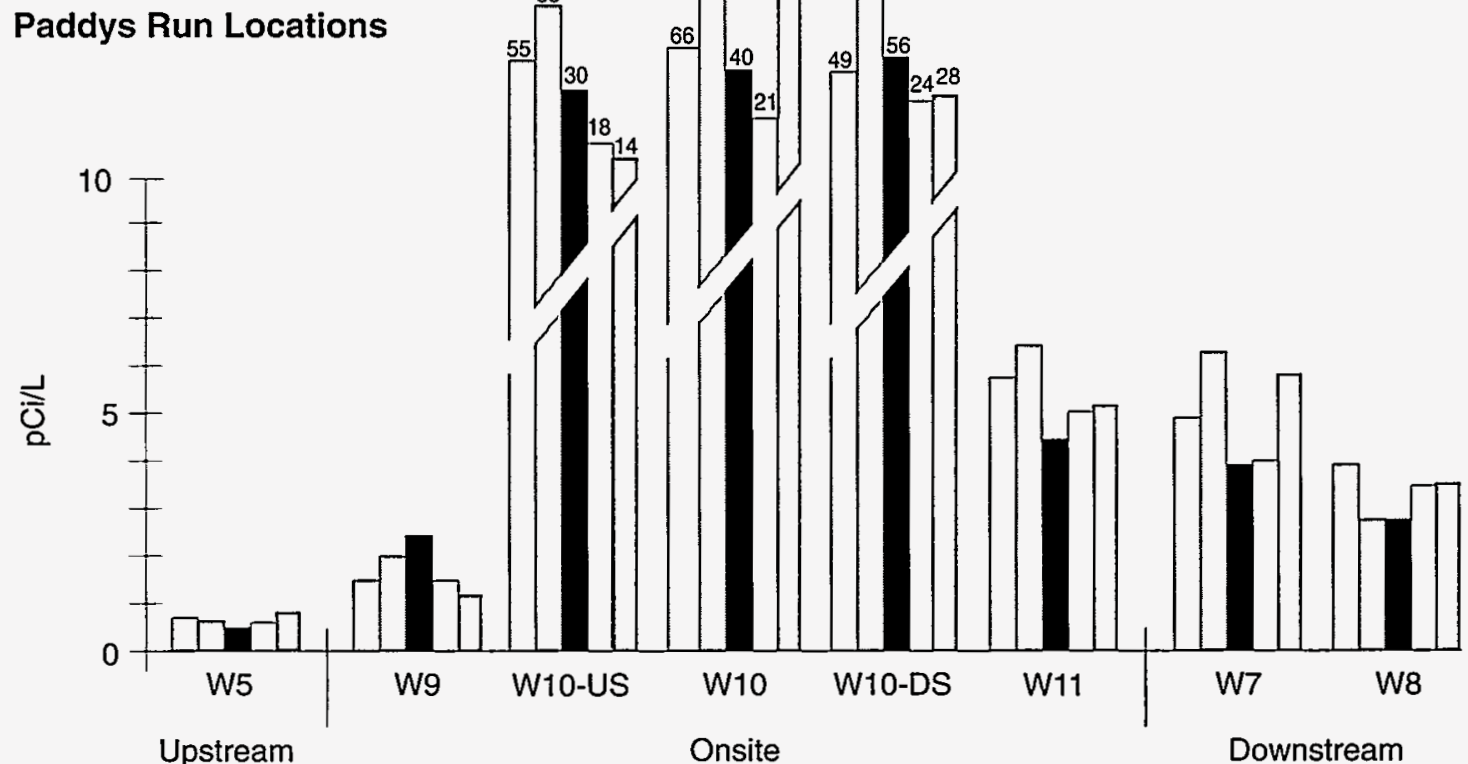


son purposes only). Both concentrations were at $0.22 \%$ of the DCG. Figure 36 shows five-year trends of uranium concentrations in surface water from the Great Miami River and Paddys Run.

Radium-226, radium-228, strontium-90, cesium-137, and technetium-99 results from Great Miami River samples were consistent with previous years. These data support the results in Table 12, demonstrating that the concentrations of these radionuclides in the liquid effluent discharged to the river were very low and resulted in very little, if any, increase in the concentrations already present in the river.

Monitoring personnel used upstream sampling point W5 to determine concentrations of uranium and radium naturally present in Paddys Run. The data indicate that the uranium and radium concentrations found in this stream were slightly higher downstream of the site (W7 and W8) than they were upstream (W5). However, average uranium and radium concentration at all Paddys Run monitoring locations were well within DOE guidelines for drinking water standards (again used only for comparison purposes). Uranium concentrations ranged from $0.22 \%$ of the DCG at W9 to 5.1\% at W10-DS. W10-DD, which leads into Paddys Run, was $79.6 \%$ of the DCG. High average values from W10-US, W10, and W10-DS were due to a few, high, weekly results. The elevated value in the drainage ditch sample location, when compared to both $\mathrm{W}-10$ and the downstream location (W10-DS), suggests that the drainage ditch, as well as other factors, may contribute to the overall uranium concentrations in Paddys Run. (See Table 12 on pages A-16 and A-17.)

\section{Sediment Sampling for Radionuclides}

Contaminants present in surface water can settle or precipitate and thereby accumulate in sediment. Sampling and analysis of sediment provide a way to evaluate possible cumulative effects of routine discharges of treated effluents into the Great Miami River and the effects of stormwater runoff into Paddys Run.

\section{Sampling Methodologies}

In early June, technicians collected sediment samples only at those locations where sediment was most likely to accumulate. Figure 37 on the next page illustrates the following locations for sample collection:

- Eight locations at 100-meter (328-ft) intervals along the SSOD;

- Five locations along the Great Miami River;

- Twelve locations along Paddys Run north of the SSOD;

- Five locations along Paddys Run south of the SSOD; and

- Four background locations along Paddys Run, north of the site.

Technicians collected one sample at each location and were taken from strategically chosen locations, representative of the most recent and greatest amount of sediment deposited. 


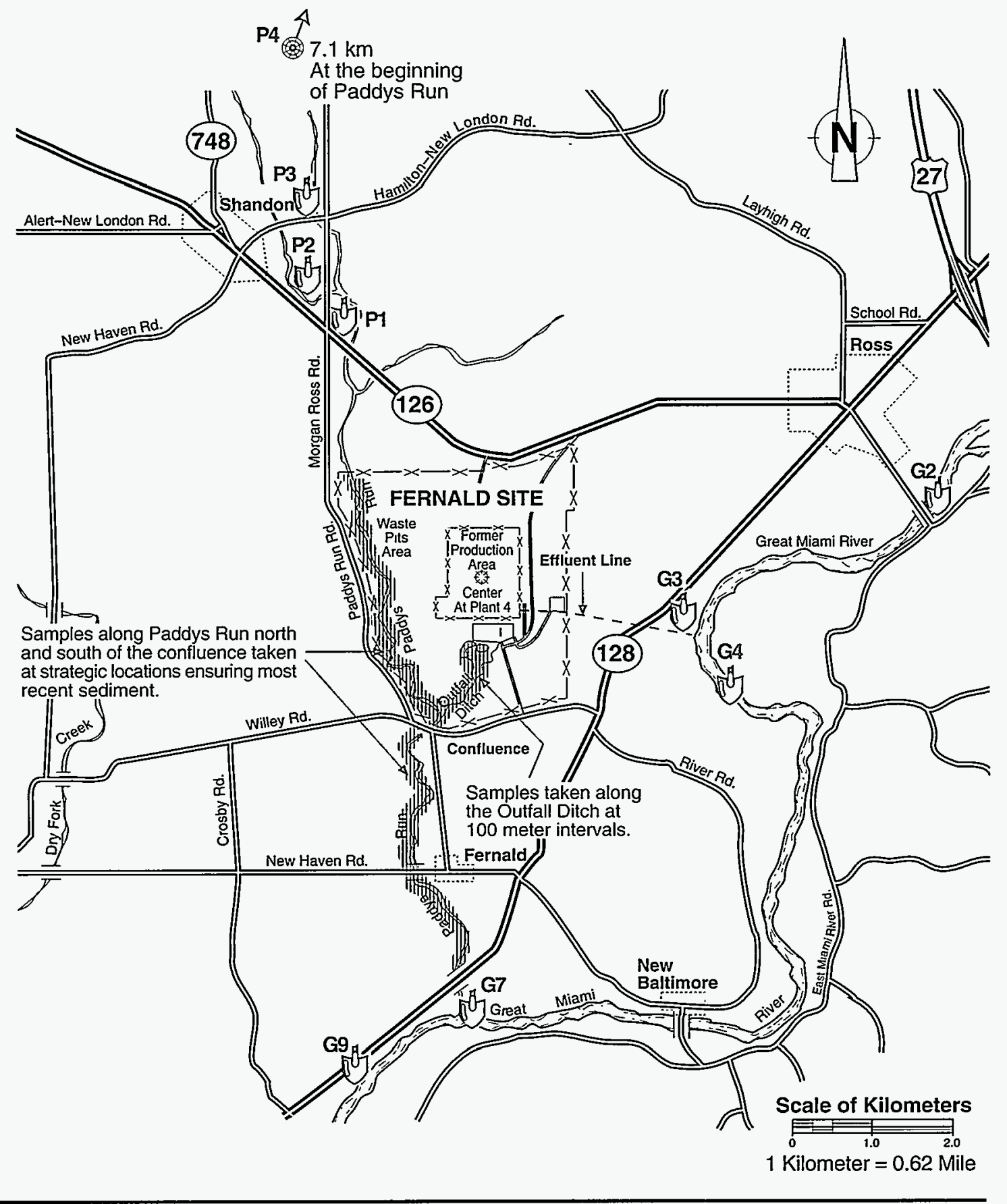

\section{LEGEND}

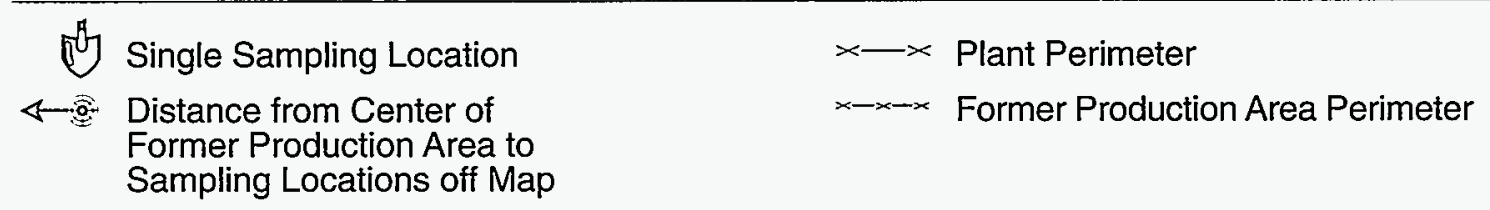


In 1995, all sediment samples were analyzed for total uranium. Samples taken from the SSOD, Paddys Run above the SSOD, and Paddys Run background were also analyzed for radium-226 and isotopes of thorium.

\section{Results of Laboratory Analyses}

Presently, there are no DOE or USEPA guidelines or standards for uranium or other radionuclides in sediment. However, the data in Table 14 on page A-21 show there were no noticeable differences in the concentration of uranium and other radionuclides found in sediment samples collected from the Great Miami River upstream and downstream of the site's effluent discharge line. Therefore, the site's liquid effluent discharges did not cause any discernible increase in the levels of radionuclides in Great Miami River sediment.

Radium and thorium results for 1995 were consistent with those found in recent years. Total uranium results from Paddys Run locations in 1995 were also similar to those in 1994. However, the average uranium concentration in the SSOD $5.55 \pm 1.20 \mathrm{pCi} / \mathrm{g}(8.21 \pm 1.78 \mathrm{ppm})$ was still above background levels. Uranium concentrations in individual locations along this ditch have been elevated in previous years as well, probably because of runoff from onsite stormwater flowing into the SSOD over the years.

\section{Fish Sampling for Uranium}

The fish population of the Great Miami River is a component of the liquid pathway that Fernald technicians have been sampling for over ten years. With the aid of a research team from the University of Cincinnati, the sampling team utilized electrofishing, one of the most efficient methods for collecting fish samples. This method is unbiased with respect to both size and species.

\section{Sampling Methodologies}

In 1995, 72 fish samples, representing 549 fish that were collected, were analyzed for uranium. The samples were collected at three River Mile (RM) sites along the Great Miami River (see Figure 38 on the next page):

- River Mile (RM) 38 - below the Route 127 bridge, north of Hamilton;

- RM 24 - at the Fernald site effluent discharge; and

- RM 19 - at the outfall point of Paddys Run.

RM 38 is used as a background location. Because of two dams in Hamilton, this fish population is physically isolated from both downstream activity and migration. Locations RM 24 and RM 19 have the potential to be influenced by the backwater species that migrate up from the Ohio River. The variety of fish collected included gizzard shad, bluntnose minnow, carp, white bass, green sunfish, emerald shiner, steelcolor shiner, skipjack herring, golden redhorse, highfin carpsucker, northern hogsucker, quillback, river carpsucker, longnose gar, 
Figure 38: Fish Sampling Locations

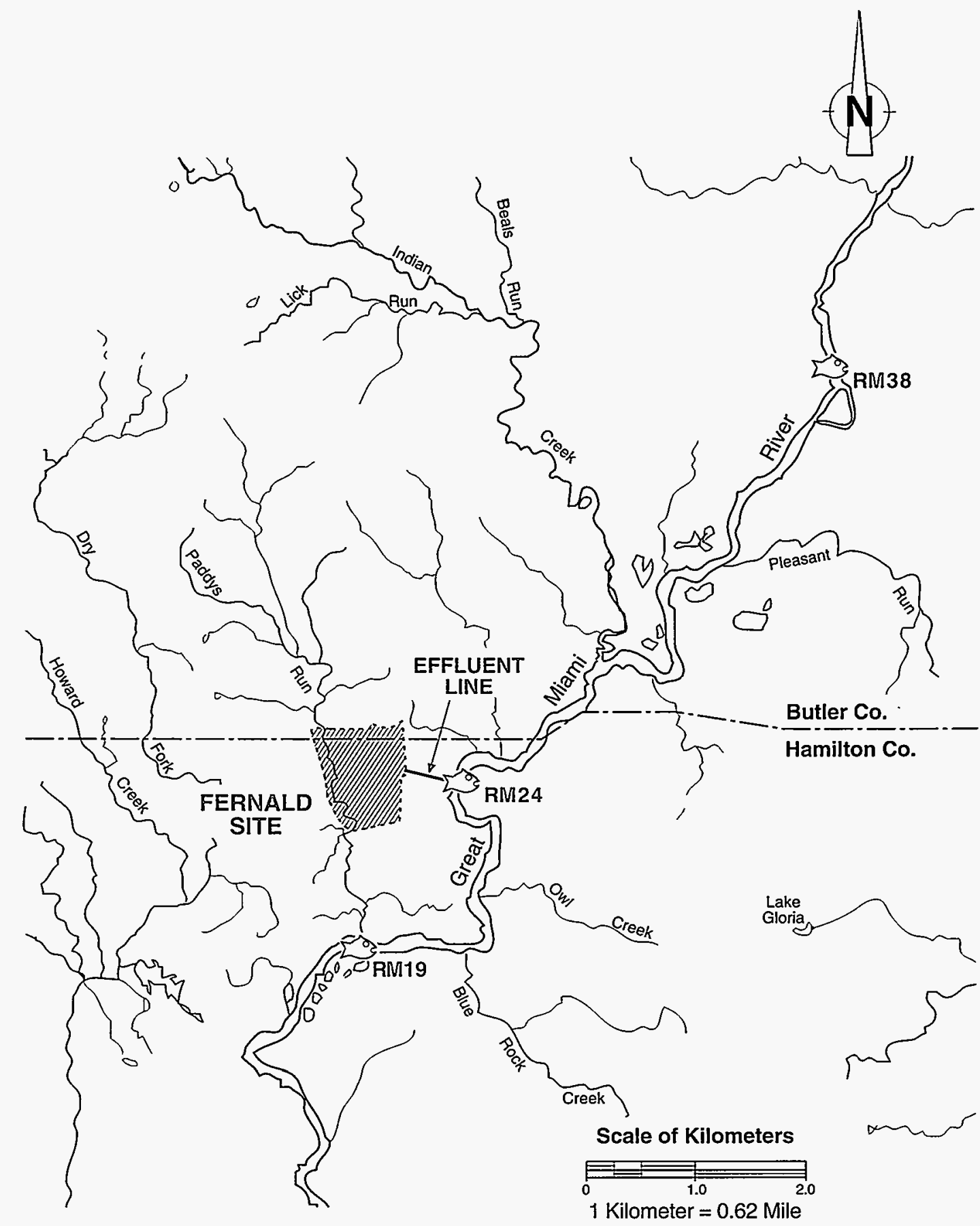

\section{LEGEND}

Fernald Site

ऽampling Location 
smallmouth buffalo, channel catfish, flathead catfish, yellow bullhead, largemouth bass, black crappie, bluegill, longear sunfish, smallmouth bass, silverjaw minnow, logperch, sauger, and freshwater drum.

\section{Results of Laboratory Analyses}

The fish population of the Great Miami River has been stable over the course of this study. In 1995, the Fernald site was determined to have no effects on the distribution of fish. The fish species appear to be in similar health regardless of sampling location (upstream or downstream from the site). ${ }^{28}$

Table 15 on page A-22 contains the average uranium concentrations reported in fish from all three sampling locations. Overall, the 1995 total uranium results are consistent with or lower than results from recent years at all locations. The estimated dose from eating fish caught in the Great Miami River near the Fernald site outfall is discussed in Chapter Seven.

By limiting the concentration of radionuclides in the effluent and reducing the amount of stormwater runoff to Paddys Run, the site can lessen its impact on various components of the liquid pathway.

\section{Monitoring For Nonradioactive Pollutants}

The site controls the discharge of nonradioactive pollutants in liquid effluent to meet the requirements of the site's National Pollutant Discharge Elimination System (NPDES) permit. The NPDES permitting process for the site is under the jurisdiction of the State of Ohio to control the discharge of nonradioactive pollutants to Ohio waters. The permit specifies sampling locations, sampling and reporting schedules, discharge limits, and other restrictions on the site's effluents discharged to the Great Miami River and Paddys Run. Table 11 on pages A-15 through A-17 contains the NPDES monitoring data for 1995. A diagram of all monitoring locations is shown in Figure 35 (on page 105). Out of 2,367 NPDES samples taken in 1995,37 were out of compliance.

By controlling the concentration of radionuclides in the effluent and by reducing the amount of stormwater runoff to Paddys Run, the site can lessen its impact on the various components of the liquid pathway. In particular, surface water runoff can enter the aquifer and influence groundwater quality. The next chapter further investigates the liquid pathway through the groundwater component. 


\section{LIQUID PATHWAY: GROUNDWATER MONITORING}

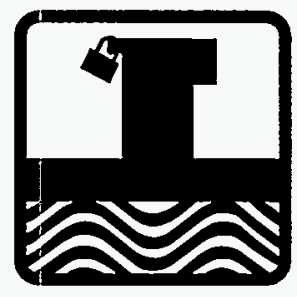




\section{Liquid Pathway: Groundwater Monitoring}

This chapter continues the discussion of the liquid pathway, as surface water runoff can leach through the soil and may contaminate the groundwater. The site carefully monitors the groundwater beneath and in the vicinity of the site to identify and track the movement of pollutants which may be present in the Great Miami Aquifer. Scientists can analyze the groundwater and soils sampled during drilling operations to learn much about the soil and its ability to restrict the movement of contaminants into the groundwater. This enables the site to better define the steps it should take to control present contamination and to prevent additional contamination from occurring.

\section{Results in Brief: 1995 Liquid Pathway: Groundwater}

Private Well Sampling for Uranium - Thirty-three private wells were sampled for uranium in 1995. Laboratory analyses of the samples indicated three wells had average uranium concentrations above the proposed standard of 13.5 $\mathrm{pCi} / \mathrm{L}(20 \mathrm{ppb})$. Each of these wells is located in an area of known uranium contamination called the South Groundwater Contamination Plume (South Plume). Thirty-two private wells were screened for nonradioactive pollutants. Two wells showed a detection of contaminants above the Primary Drinking Water Standards. One well sample exceeded the $0.05 \mathrm{mg} / \mathrm{L}$ standard for lead and one slightly exceeded the $0.01 \mathrm{mg} / \mathrm{L}$ standard for cadmium in drinking water.

RCRA Groundwater Monitoring Program - Thirty-three groundwater wells were sampled quarterly for RCRA constituents in 1995. Nine constituents from this program had concentrations above the corresponding Final Remediation Levels (FRLS). Please see page 116 for a discussion on FRLs.

South Plume Removal Action Monitoring Program - Sixty-one groundwater monitoring wells in the South Plume were sampled quarterly in 1995. Twelve exhibited concentrations of total uranium above $20 \mathrm{ug} / \mathrm{L}(20 \mathrm{ppb}$ ). Six wells had gross alpha concentrations exceeding $15 \mathrm{pCi} / \mathrm{L}$. Three wells indicated arsenic above the primary drinking water standard of $0.05 \mathrm{mg} / \mathrm{L}$. All of these wells are within the South Plume recovery system.

KC-2 Warehouse Well Monitoring Program - Monitoring was performed semi-annually at this well during 1995 . One of the two sample rounds indicated concentrations of uranium and total metals at or above the established standards. The second sample round showed these concentrations were below the standards.

Coal Pile Runoff Basin Monitoring Program - Two wells were monitored on a quarterly basis for total uranium and non-radioactive parameters in 1995. Sulfate and total dissolved solids were detected above the secondary drinking water standard. 


\section{History Of Groundwater Monitoring At The Site}

Several groundwater monitoring programs have evolved throughout the history of the site. The original three production wells drilled during the construction of the Feed Materials Production Center in 1951 were the first to be monitored. From 1959 to 1965 , the site installed 11 monitoring wells in the waste pits area to see if pit operations were affecting the groundwater. These waste pits and production area wells constituted the original Environmental Monitoring Groundwater Program.

In late 1981, the State of Ohio sampled three wells south of the Fernald site and found elevated levels of beta activity. This activity was due to potassium-40, a naturally occurring radionuclide which was not present in site production materials. However, sampling also detected above-background concentrations of uranium in other wells near the site. This information was reported to the State in November, 1981.

These findings prompted an expansion of groundwater monitoring in the area. Environmental Monitoring began sampling existing area wells in February 1982, and by 1984, the Fernald site officially established the Radiological Environmental Monitoring (Private Well) Program with the monthly sampling of 19 privately-owned wells.

In August 1985, the site initiated a Resource Conservation and Recovery Act (RCRA) detection groundwater monitoring program around Waste Pit 4 in response to requirements of federal and state hazardous waste regulations. From 1980 to 1983 hazardous waste, as defined under RCRA regulations, had been placed in Waste Pit 4 . The detection monitoring program was initiated to determine if hazardous waste was escaping from Waste Pit 4 and entering the groundwater. The detection monitoring program confirmed that the groundwater had been impacted and as a result the program was shifted to a RCRA Assessment Monitoring Program in May, 1988. The objective of the RCRA Assessment Monitoring Program is to determine the rate of migration and extent of any hazardous waste contamination in the groundwater.

The RCRA Groundwater Program at the Fernald site was altered in 1991 when the RCRA Part A Permit Application identified 51 Hazardous Waste Management Units (HWMUs), including nine land-based HWMUs requiring groundwater monitoring. Before June 1991, Waste Pit 4 was the only identified regulated unit requiring groundwater monitoring. The RCRA Groundwater Monitoring Plan was submitted to the EPAs in December 1991, replacing the RCRA Assessment Monitoring Program. The Groundwater Monitoring Plan was designed to monitor groundwater downgradient of the nine land-based units. The site defined three monitoring well networks to provide adequate monitoring of the waste pits area, the former production area, and the site property boundary. 


\section{Fernald Site Groundwater W/ells}

Figure 39 depicts a typical well at the Fernald site. The depth of a Fernald site well and the waterbearing zone into which it extends are denoted by the first digit of the well number. Wells extending into the perched groundwater within the till are denoted as $1000-$ series wells. Wells extending into the upper portion of the sand and gravel aquifer are denoted as $2000-$ series wells. The 3000 -series wells are placed within the middle portion of the sand and gravel aquifer, and the 4000-series wells are installed in the sand and gravel aquifer beneath a layer of "blue clay." Sometimes a group of two or more wells of different depths are drilled at the same location to sample different water-bearing zones within the groundwater; these groups are called cluster wells.

\begin{abstract}
sampling groundwater. These wells are located both on and off the Fernald site. They range from $11-76$ meters ( $35-250$ feet) deep.
\end{abstract}

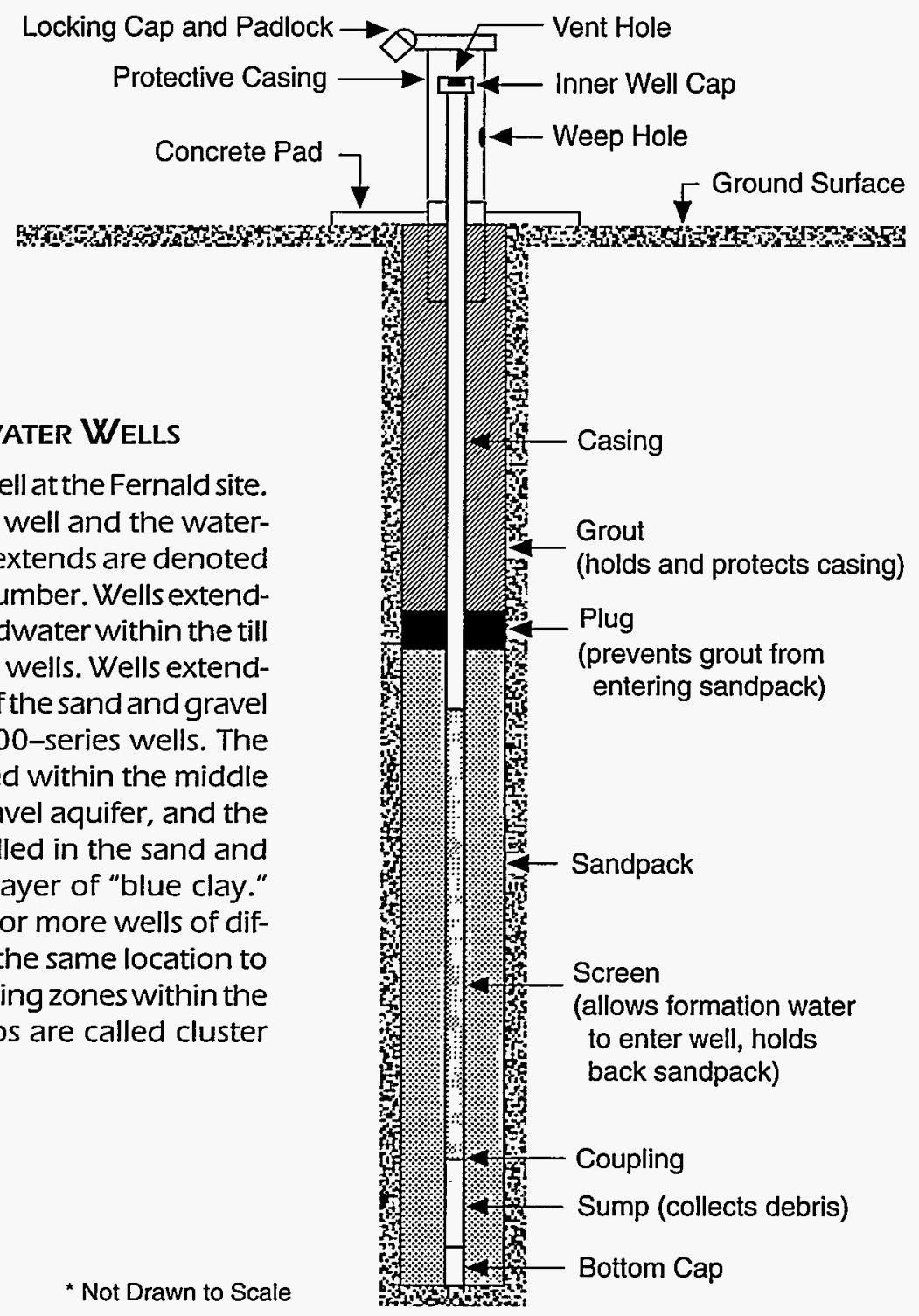

By mid-1993, the property boundary network was near completion and well installation on the Production Area network was proceeding. At that time, it was determined that it would be impractical to meet RCRA requirements under the current monitoring program. Specifically, difficulties were encountered while trying to comply with RCRA requirements, causing a duplication of efforts in Comprehensive Environmental Response, Compensation, and Liability Act (CERCLA) and RCRA activities at the site. 
In an effort to integrate CERCLA and RCRA monitoring activities under a single program, Fernald site personnel proposed an alternate monitoring program. This program is comprised of two components:

1. Groundwater characterization activities under CERCLA (results are provided in Operable Unit 5 RI/FS documents) and

2. Quarterly groundwater monitoring of the downgradient property boundary (RCRA Groundwater Monitoring Program).

In September 1993, this program was accepted by the State of Ohio. The current RCRA Groundwater Program monitors wells located along the downgradient boundary of the Fernald site for a select list of contaminants to document the quality of groundwater potentially leaving the property boundaries of the Fernald site. These wells are shown in Figure 41.

In May 1988, additional groundwater sampling was initiated as part of the Remedial Investigation and Feasibility (RI/FS). This CERCLA-driven study investigated the nature and extent of potential environmental impacts from past and current operations at the site, with particular regard to the Great Miami Aquifer. By late 1989, more than 200 wells were being sampled under the various programs. Through this effort, an extensive number of wells were sampled to characterize the groundwater.

\section{Final Remediation LeVels (FRLs)}

The Operable Unit 5 Record of Decision (ROD), signed by EPA in January 1996, established final remediation levels (FRLs) for Fernald site-related contaminants in environmental media (i.e. soil, surface water, sediment, and groundwater) at the site. These FRLs are legally binding cleanup levels that will be used to track and certify the completion of the Fernald site's remediation process. FRLs were specifically developed for the Great Miami Aquifer for those constituents that are presently in the Great Miami Aquifer and those thathave the potential to reach the aquifer within 1,000 years at levels that pose an unacceptable risk to human health and/or the environment.

FRLs were generally developed by the following process. First, a risk assessment was performed to determine constituent-specific concentrations of Fernald site related contamination that may pose an unacceptable risk to human health or the environment (risk-based concentrations). This assess- ment was completed using Remedial Investigation findings on Fernald site related contamination and conservative, EPA-approved methods.

After risk based concentrations were determined for each constituent, they were compared to:

- regulatory-based standards (e.g. primary drinking water standards);

- the lowest reasonable and achievable laboratory detection level; and

- background concentrations.

From this comparison the highest concentration of a particular constituent that complies with regulatory-based standards was selected as the FRL.

The above description of the cleanup level determination process for environmental media at the Fernald site is a generalization. Detailed discussion of this process is provided in Section 2 of the Operable Unit 5 Feasibility Study Report (DOE, 1995). 


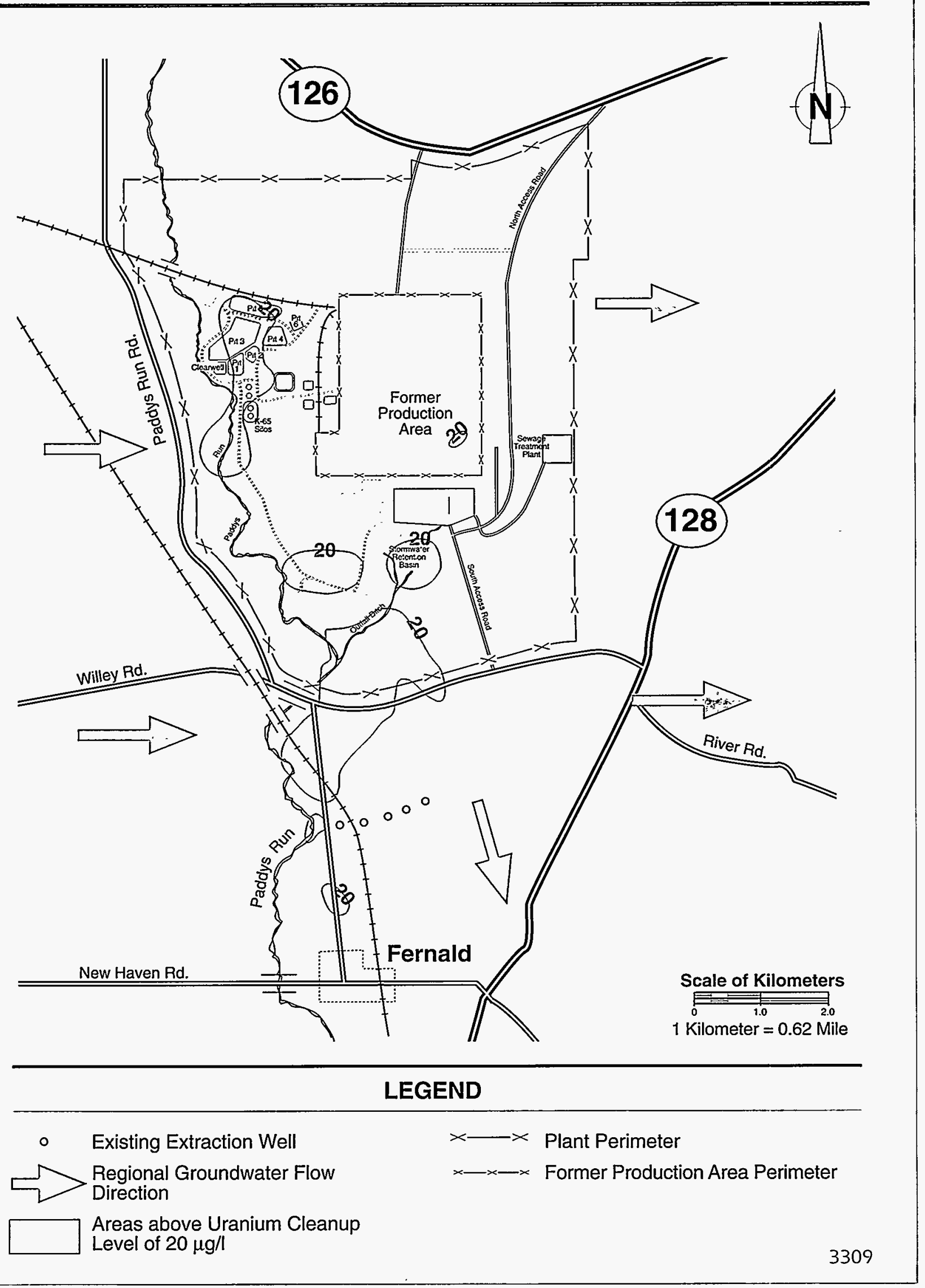


Figure 41: Remediation Well Locations

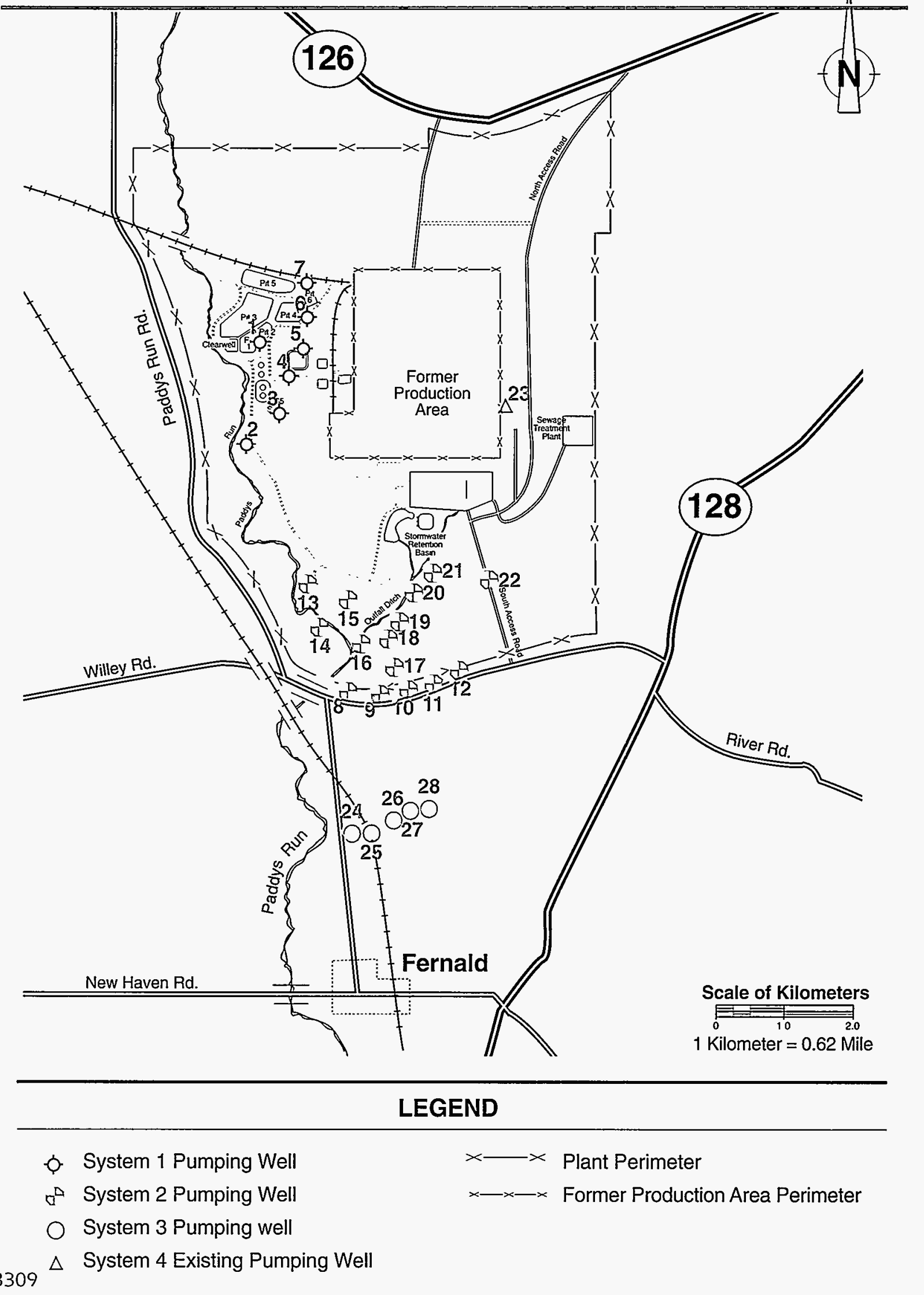


As a result of evaluating the data collected for the RI/FS process, the nature and extent of groundwater contamination was determined. The following discussion provides information pertaining to the remedy for the cleanup strategy of the Great Miami Aquifer.

\section{Fernald Site Groundwater Remedy}

The areas of the Great Miami Aquifer requiring remediation are shown in Figure 40. These areas were identified in the Operable Unit 5 Feasibility Study and Record of Decision. The groundwater in these areas will be remediated by pumping and treatment.

After the areas requiring remediation were identified, groundwater modeling was used to determine the best locations for pumping wells. This effort identified 28 pumping well locations within the contaminated areas of the aquifer. These 28 pumping well locations, shown in Figure 44, are divided into four pumping systems located both onsite and in the South Plume area. The modeling suggests that a combined maximum pumping rate of 4,000 gallons per minute from the four pumping systems will be required for up to 27 years to remediate the aquifer. Further efforts are being made to reduce the number of years to remediate the aquifer by considering enhancement technologies such as groundwater reinjection and by adding additional pumping locations.

The selected remedy consists of the following key components for regional groundwater:

- Extraction of contaminated groundwater until such time as final remediation levels are attained at all points in the impacted areas of the Great Miami Aquifer;

- Performance of an engineering study to examine the viability of applying reinjection techniques to enhance contaminant recovery from the aquifer system; application of reinjection to groundwater restoration activities where established to be economically and technically viable; and

- Collection of recovered groundwater for treatment and/or discharge to the Great Miami River or reinjection (if deemed appropriate).

\section{Routine Groundwater Monitoring Activities for 1995}

As part of the total liquid pathway, the movement of radioactive pollutants into and through the groundwater is of significant concern. This section discusses the results of five programs designed to monitor and assess the groundwater within the vicinity of the Fernald site. Each of these five programs conducts sampling activities on a routine basis: 
- Radiological Environmental Monitoring (Private Well) Program

- RCRA Groundwater Monitoring Program

- South Plume Removal Action Monitoring Program

- KC-2 Warehouse Well Monitoring Program

- Coal Pile Runoff Basin Monitoring Program

The following sections provide a summary of each program including a brief history and a summary of monitoring activities and results for both radiological and non-radiological sampling efforts.

\section{Radiological Environmental Monitoring (Private Well) Program}

The longest running groundwater monitoring effort (which is ongoing) is the $R \boldsymbol{a}$ diological Environmental Monitoring (Private Well) Program. The program was initiated in 1982 in response to monitoring results indicating above background concentrations of uranium in private wells near the site. By 1984, the Fernald site had officially established the program with the monthly sampling of 19 privatelyowned wells.

Under the current program, 33 private wells are routinely sampled. At a property owner's request, any drinking water well near the site is sampled for uranium and the one-time results are reported to the well owner. If any "special request" sample shows a questionable or significant total uranium concentration, or if the well is determined to provide critical groundwater information in an area, the property owner has the option to participate in the routine sampling program. Wells are sampled monthly or quarterly depending upon the location and sampling results are reported annually in the Site Environmental Report.

\section{Proposed USEPA Standard for URANIUM IN DRINIKING Water}

In addition to comparing results against background levels for substances in the environment, environmental monitoring results are often compared to standards or guidelines. These standards set concentration limits for specific substances in a medium. Standards and guidelines are always set lower than the lowest concentration known to cause illness or injury to humans or the environment.

USEPA is responsible for setting standards for substances in drinking water throughout the United States; National Primary Drinking Water Standards are enforceable by federal law. However, in the absence of a USEPA standard for a particular sub- stance, guidelines are set by other agencies such as DOE and the Nuclear Regulatory Commission (NRC); these guidelines, however, are only applicable to DOE- or NRC-governed sites.

Through 1990, the only reference for uranium in drinking water was a DOE guideline of $20 \mathrm{pCi} / \mathrm{L} / 30$ PpD). Past site reports have used this reference for comparison. However, in 1991, USEPA proposed a standard for uranium in drinking water of 13.5 $\mathrm{pCi} /$ Lor $20 \mathrm{ppb}$. As of February 1996, this standard had not yet been approved. This 1995 report will continue to use this proposed USEPA standard for comparison with well monitoring results, as it is the more stringent of the two. 


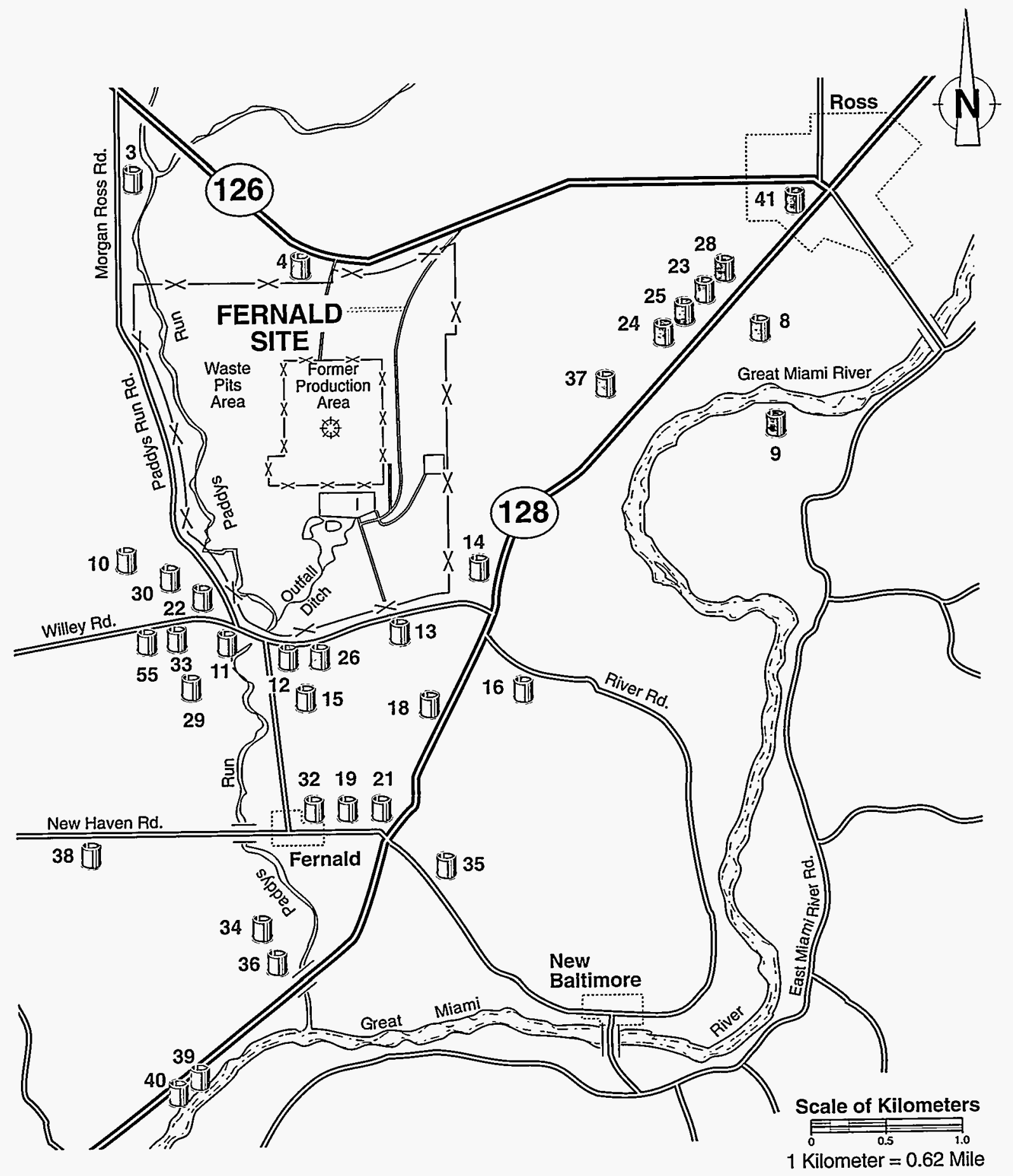

\section{LEGEND}

Sampling Location

$x \longrightarrow \times$ Plant Perimeter

$x-x-x$ Former Production Area Perimeter 
Figure 43: Average Uranium Concentrations in Private Wells, 1991-1995
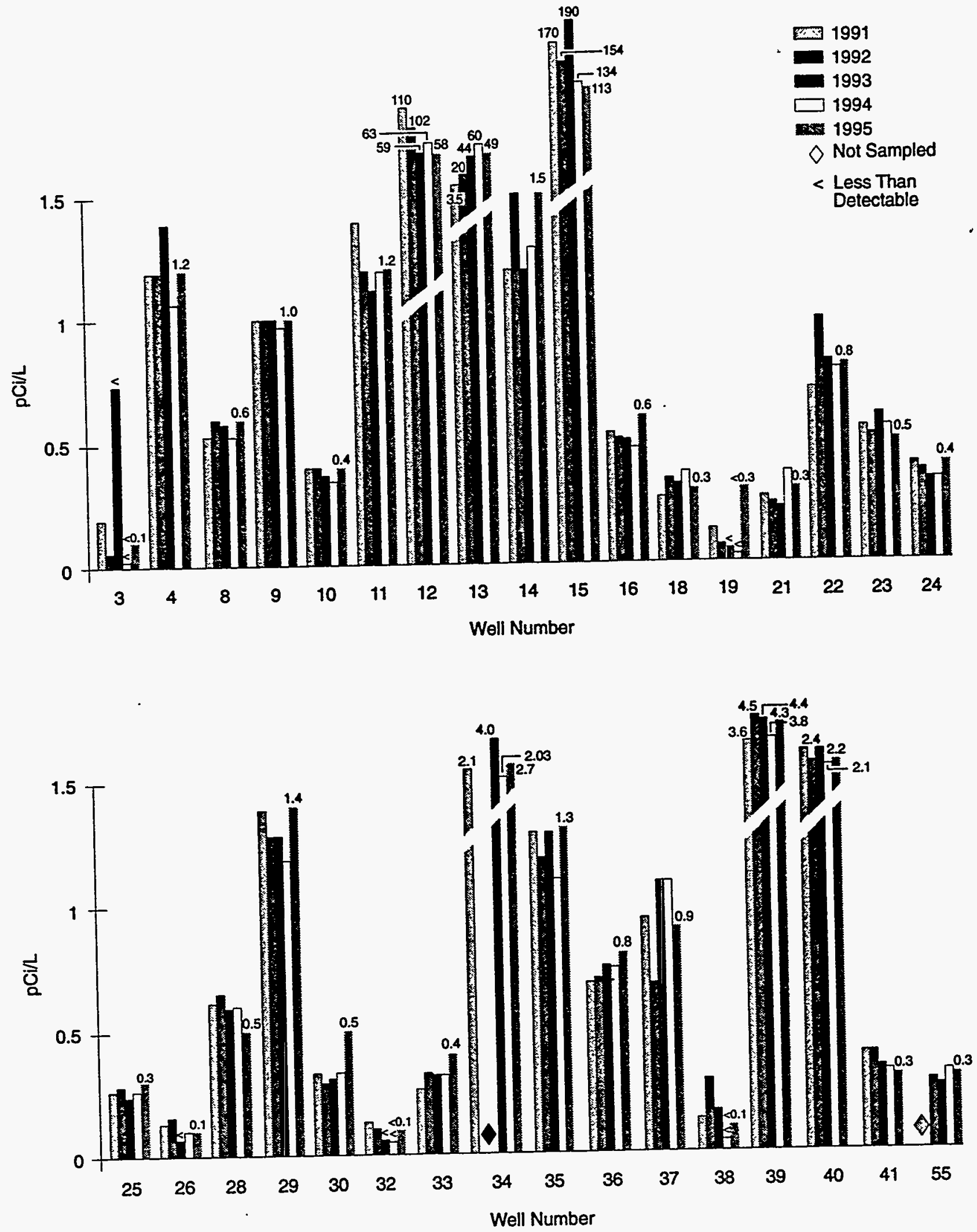

- 1995 Data orginally reported in micrograms per liter $(\mu g / L)$ 
During 1995, 33 private wells (see Figure 42 on page 121) were sampled monthly or quarterly for total uranium. Three wells exceeded the proposed Maximum Contaminant Level (MCL) of $20 \mu \mathrm{g} / \mathrm{L}(13.5 \mathrm{pCi} / \mathrm{L})$ for uranium with average concentrations of $79.3 \mu \mathrm{g} / \mathrm{L}(53.6 \mathrm{pCi} / \mathrm{L}), 72.2 \mu \mathrm{g} / \mathrm{L}(48.8 \mathrm{pCi} / \mathrm{L})$, and $166.7 \mu \mathrm{g} / \mathrm{L}(112.7$ $\mathrm{pCi} / \mathrm{L}$ ). These three wells are located south of the facility in an area of uranium contaminated groundwater referred to as the South Plume (See Figure 42). The groundwater in this area is being remediated as part of the South Groundwater Contamination Plume Removal Action.

During 1995, 31 private wells were sampled for nonradioactive constituents. One well had lead and cadmium concentrations above the MCLs of $0.015 \mathrm{mg} / \mathrm{L}$ and $0.005 \mathrm{mg} / \mathrm{L}$ respectively. This well is also located in the South Plume.

Several wells exhibited iron and manganese concentrations above Secondary Drinking Water Standards. However, these results are consistent with 1994 results and are typical for areas with naturally occurring iron and manganese such as the Fernald site. ${ }^{31,32,33,34}$

The uranium concentration at Well 13 has been slowly increasing since 1989 (see Table 18 on page A-29). In June 1992, an ion exchange system was installed at this location. This system is designed to remove the uranium from the well by filtering the water. Results from the water filtered through the ion exchange system indicate that the uranium is removed and the uranium concentration in the treated water is within the background range for this area. Well 13, located just south of the site in an area of known groundwater contamination, continues to be a point of monitoring. The uranium-contaminated water in this area, known as the South Plume, is being pumped from the aquifer as part of the South Groundwater Contamination Plume Removal Action.

\section{RCRA Groundwater Monitoring Program}

The focus of the current RCRA groundwater monitoring program is to detect and assess potential changes in groundwater conditions at the Fernald property boundary before they impact offsite locations. This is accomplished through quarterly sampling of 33 wells (see Figure 44) located along the downgradient property boundary for approximately 90 site-specific radiological and nonradiological constituents.

As identified in the discussion of the history of this program, the RCRA Groundwater Monitoring Program was initiated around Waste Pit 4 in 1985 in compliance with federal and state hazardous waste regulations to determine if the hazardous waste unit was impacting groundwater. By 1988, monitoring results from the program indicated that Waste Pit 4 was impacting the groundwater.

In 1991, additional units at the Fernald site were identified as requiring groundwater monitoring under RCRA regulations. It was necessary to develop a monitoring 
strategy to integrate CERCLA and RCRA monitoring activities in order to eliminate redundancies. For this reason, the Fernald site proposed an alternate monitoring approach which was accepted by the OEPA in September, 1993. The alternate monitoring approach consists of groundwater contaminant characterization under CERCLA and groundwater monitoring at the downgradient facility boundary under RCRA to detect and assess potential changes in groundwater conditions at the Fernald property boundary.

In the past, the data from the RCRA program were compared against Primary and Secondary Drinking Standards, which are known as MCLs, to assess potential impacts. However, in 1995, data were compared against proposed final remediation levels (FRLs) to reflect the transition from characterization to remediation.

The 1995 results from the RCRA monitoring program confirm that other than the contamination comprising the South Plume (currently addressed under Removal Action 3), there are no concentrations of contaminants that trigger the need for action ahead of the final groundwater remedy. This finding is consistent with the results for the previous program years (1993 and 1994).

Nine constituents (fluoride, antimony, cadmium, lead, manganese, nickel, zinc, radium-228 and total uranium) from the RCRA monitoring program wells were found to have concentrations that minimally exceed their corresponding FRL (see Table 19 on page A-30). Except for two constituents at two locations (manganese at Well 2424 and total uranium at Well 3069), there were no trends in the data that would indicate increasing concentrations over time. These results indicate that there is no need for action prior to the final groundwater remedy. Total uranium concentrations above the FRL of $20 \mu \mathrm{g} / \mathrm{l}$ (the same as the Primary Drinking Standard) are being addressed under Removal Action 3 in the South Plume.

\section{South Plume Removal Action Monitoring Program}

In order to prevent the further migration of contamination to the south with regional groundwater flow, Removal Action 3 was initiated in August 1993 by installing five pumping wells in the South Plume area. These five wells pump contaminated groundwater from the South Plume area back to the site where it is treated, monitored, and discharged to the Great Miami River through the Fernald outfall discharge line. Figure 40 shows the extent of the uranium contamination within the groundwater in the vicinity of the Fernald site. The shaded areas in the figure represent those areas where the uranium contamination in the groundwater exceeds the Primary Drinking Water Standard of $20 \mu \mathrm{g} / \mathrm{L}$ (20 ppb). As shown in the figure, part of the uranium contamination has moved offsite to the south. This area is referred to as the South Plume.

In order to monitor the performance of the five pumping wells, 61 monitoring wells in the South Plume area are monitored quarterly to determine the effective- 
Figure 44: South Plume Removal Action Monitoring and Pumping Wells

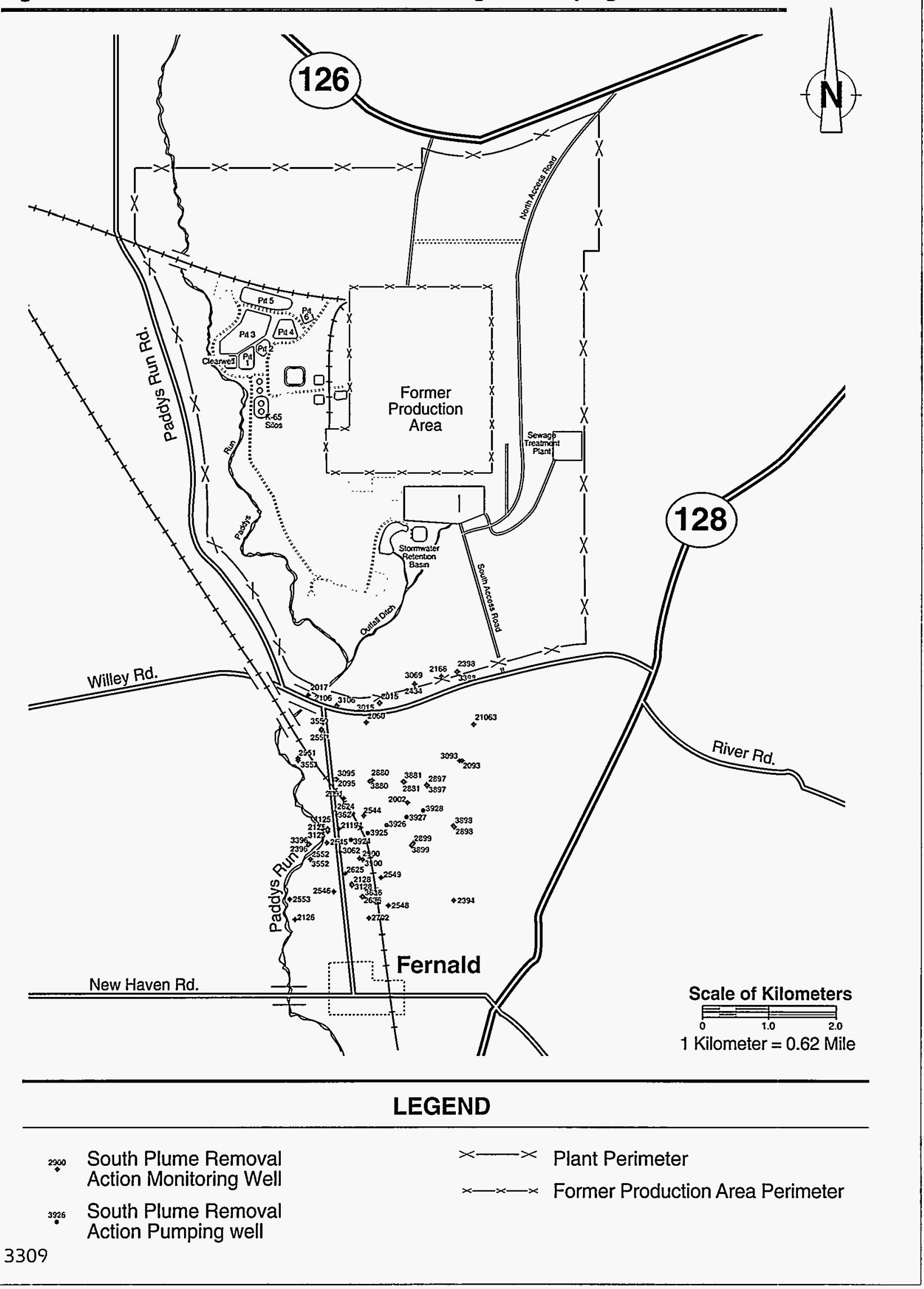


ness of the removal action (see Figure 44). The monitoring results are reported semi-annually in the South Plume Removal Action System Evaluation Report. This report is submitted to DOE and USEPA.

In January 1995, pumping well 5 on the east end of the pumping system was permanently shut down because monitoring data and groundwater modeling showed that this well is no longer needed to remove contaminants from the aquifer. Since this time, the pumping system has operated with four pumping wells pumping at a combined rate of 1,400 gallons per minute (gpm). As of December 31, 1995, the pumping system has pumped over 1.6 billion gallons of uranium-contaminated groundwater resulting in the removal of over $102 \mathrm{~kg}$ (223 lbs) of uranium from the aquifer in the South Plume area. Monitoring results show that by the second half of 1995, the maximum uranium concentration in the South Plume area has decreased from a high of $300 \mu \mathrm{g} / \mathrm{L}(300 \mathrm{ppb}, 203 \mathrm{pCi} / \mathrm{L}$ ) before pumping began to $170 \mu \mathrm{g} / \mathrm{L}(170 \mathrm{ppb}, 115 \mathrm{pCi} / \mathrm{L})$.

Monitoring from the second half of 1995 showed that 12 monitoring wells exhibited uranium concentrations above the $20 \mu \mathrm{g} / \mathrm{L}(20 \mathrm{ppb}, 13.5 \mathrm{pCi} / \mathrm{L}$ ) primary drinking water standard for uranium. The highest concentration was $170 \mu \mathrm{g} / \mathrm{L}$ ( $170 \mathrm{ppb}, 115 \mathrm{pCi} / \mathrm{L}$ ) (see Table 20 on page A-30) and occurred at wells 2061 and 2095 , both of which are within the South Plume area where contamination is being removed by the pumping system. The remaining ten wells with uranium concentrations above $20 \mu \mathrm{g} / \mathrm{L}(20 \mathrm{ppb})$ are also within the area where contamination is being removed by the pumping system.

Additional South Plume monitoring data for radioactive constituents from 1995 showed that six wells exhibited gross alpha concentrations above the primary drinking water standard of $15 \mathrm{pCi} / \mathrm{L}$. Well 2015 exhibited the highest gross alpha concentration with a value of $92 \mathrm{pCi} / \mathrm{L}$. Of the remaining five wells with gross alpha concentrations above the $15 \mathrm{pCi} / \mathrm{L}$ primary drinking water standard for gross alpha, all are within the area where contamination is being removed by the pumping system.

Monitoring for non-radioactive constituents showed elevated levels of arsenic above the primary drinking water standard of $0.05 \mathrm{mg} / \mathrm{L}(50 \mathrm{ppm})$ in three South Plume monitoring wells. The highest concentration of $0.1076 \mathrm{mg} / \mathrm{L}(107.6 \mathrm{ppm})$ (see Table 22 on page A-38) occurred in well 2128, which is south of the South Plume recovery system. This contamination is believed to be from other industrial activities in the area and not the Fernald site.

Some constituents were detected above their secondary standards for drinking water in 1995. However, it should be noted that many of theses constituents are naturally occurring, and their presence does not pose a threat to human health or to the environment except at considerably higher concentrations. Iron is one particularly noteworthy example of such naturally occurring elements. It is commonly found at high levels in southwest Ohio. Iron was in one South Plume monitoring 
well above the secondary standard of $0.300 \mathrm{mg} / \mathrm{L}$ ( $300 \mathrm{ppm})$. This value of 0.304 $\mathrm{mg} / \mathrm{L}$ (304 ppm) was found at well 2398. Aluminum was in three South Plume monitoring wells above the secondary drinking water standard of $0.05 \mathrm{mg} / \mathrm{L}$ $(50 \mathrm{ppm})$. The maximum detection of aluminum was $0.155 \mathrm{mg} / \mathrm{L}(155 \mathrm{ppm})$ and occurred in well 2434. As mentioned, these elevated results do not pose an immediate risk to human health or to the environment.

\section{KC-2 Warehouse Well Monitoring Program}

The KC-2 Warehouse Monitoring Program was initiated in July 1993. This program consists of monitoring one well, 41240 , which is located in the warehouse (Figure 45). Monitoring is performed on a semiannual basis for uranium and metals. This monitoring was initiated in order to determine the impacts contaminated sediment from the well was having on the groundwater. The sediment in the bottom of the well is from an unknown origin and is not typical of Great Miami Aquifer sediments.

The January 1995 sampling results for metals and total uranium indicate that the concentrations in the well for antimony, arsenic, cadmium, chromium, lead, mercury, nickel and thallium are at/or above the primary drinking water standards. It is believed that these results were affected by the high amount of sediment collected with the water samples. Special care was taken during the August sampling round to collect groundwater samples minimizing the amount of sediment. All the results from the August 1995 sampling event showed that uranium and metal concentrations were below the primary drinking water standards. This well will continue to be monitored until the $\mathrm{KC}-2$ Warehouse is dismantled in the year 2001. At this time, the well will be plugged and abandoned.

\section{Coal Pile Runoff Basin Monitoring Program}

Two wells, 1675 and 1676, installed in the perched groundwater zone within the glacial overburden are used to monitor the Coal Pile Runoff Basin on a routine basis (See Figure 45). Monitoring is conducted in accordance with Ohio Permit to Install (PTI) No. 05-4172, issued and effective on September 13, 1990. The objective of the monitoring program is to detect any leaching that might occur from the Coal Pile Runoff Basin. These wells are sampled on a quarterly basis for total uranium and non-radioactive parameters.

In 1995 , well 1675 had a maximum sulfate concentration of $369.5 \mathrm{mg} / \mathrm{L}$ and well $1676 \mathrm{had}$ a maximum sulfate concentration of $273.3 \mathrm{mg} / \mathrm{L}$, both of which are below the primary drinking water standard of $500 \mathrm{mg} / \mathrm{L}$ but above the secondary drinking water standard of $250 \mathrm{mg} / \mathrm{L}$ for sulfate. Both of these wells also showed total dissolved solids above the secondary drinking water standard of $500 \mathrm{mg} / \mathrm{L}$ with well 1675 having a maximum value of $1158 \mathrm{mg} / \mathrm{L}$ and well 1676 having a value of $940 \mathrm{mg} / \mathrm{L}$. Some constituents were detected above their secondary standards in 1995 . However, it should be noted that many of these constituents are 
Figure 45: RCRA, KC-2 Warehouse and Coal Pile Runoff Monitoring Locations

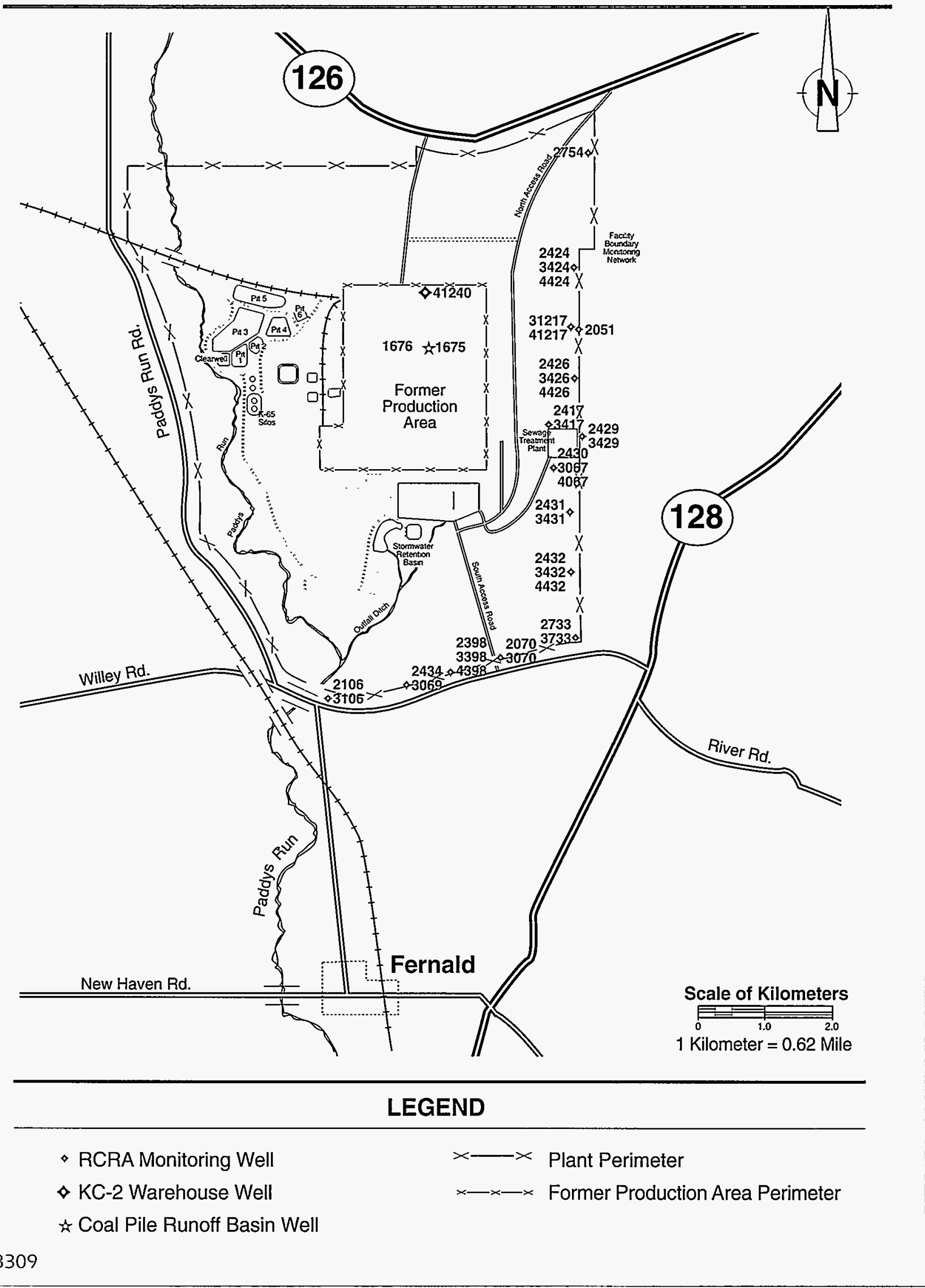


naturally occurring, and their presence does not pose a threat to human health or to the environment except at considerably higher concentrations.

Fate and transport modeling performed for the Operable Unit 5 Feasibility Study (FS) showed that the glacial overburden material above the aquifer is protective of the groundwater in the aquifer due to the limited vertical groundwater flow. Because of this, recommendations will be made to the USEPA and OEPA to terminate this monitoring program. Pending approval of this recommendation, wells 1675 and 1676 will be plugged and abandoned during remediation of the basin and demolition of the boiler plant complex.

\section{Additional Groundwater Activities for 1995}

Significant progress was made in 1995 in the selection of a final remediation strategy for Operable Unit 5 which includes groundwater. Specifically:

- The Operable Unit 5 Remedial Investigation (RI) Report (DOE 1995a) was finalized and approved by the USEPA and OEPA. ${ }^{42}$ The RI Report presents the results of nearly ten years of studies and investigations of the environmental conditions at the Fernald site and summarizes the nature and extent of contamination in all environmental media (i.e., soil, sediment, groundwater, surface water, flora, and fauna). The Operable Unit 5 RI Report concluded that the existing conditions at the Fernald site present an unacceptable risk to human and environmental receptors, thereby warranting the implementation of actions to remediate each of the environmental media.

- The data and analyses presented in the Operable Unit 5 RI Report were used as the foundation for the development of the Operable Unit 5 Feasibility Study (FS) Report (DOE 1995). ${ }^{45}$ The FS Report was finalized and approved by the USEPA and OEPA in 1995. It presents a comprehensive evaluation of alternatives for cleanup of environmental media, identifies a leading remedial alternative, and presents proposed FRLs for all constituents of concern.

- The Proposed Plan for Operable Unit 5 was finalized and approved by the USEPA and OEPA in 1995. The approval process included a public comment period to allow stakeholder concerns to be addressed. The Proposed Plan summarizes key information from the RI and FS reports and identifies the preferred remedial alternative for the site, including the strategy for remediating groundwater.

\section{On-Site Disposal Facility (OSDF) Predesign Monitoring Program}

Sampling activities for the On-Site Disposal Facility (OSDF) predesign investigation were conducted during 1995 to define the most suitable location for a facility and to provide data to support the design of that facility. The OSDF planned for 
the Fernald site will be used for long-term storage of waste (e.g., contaminated soil exceeding remediation levels). The construction of the OSDF will begin in 1997.

During 1995, perched groundwater and soil samples were collected at approximately 100 locations. The results from this investigation indicate that the best location for the OSDF is in the northeastern area of the Fernald site (Figure 46).

These conclusions along with additional field activities to be completed were identified in the Predesign Investigation and Site Selection Report (DOE 1995) that was submitted to the EPA and the OEPA in July. ${ }^{46}$ In September, EPA approved the report while OEPA gave approval conditional upon the satisfactory resolution of comments. An addendum to the predesign field investigation project-specific plan (PSP) is currently in development to satisfy OEPA comments and to implement future activities.

\section{Perched Groundwater Water Removal Action Monitoring}

An investigation was initiated in 1988 to determine the groundwater quality around Plant 6 as a result of the detection of uranium in the Plant 6 clarifier pit and cracks in the pickling room floor trench. Because perched groundwater contaminated with uranium was discovered as a result of the investigation, the Perched Groundwater Removal Action was implemented to remove and treat perched groundwater beneath Plant 6 . The investigation also revealed uranium contaminated perched groundwater around Plants $2 / 3,8$, and 9 which led to those plants being added to the scope of the removal action.

As part of the removal action, thirteen wells were installed in and around Plants $2 \beta$, 6,8 , and 9 to be used for pumping of the perched groundwater. The removal action was initiated to protect the underlying aquifer from being contaminated by the perched groundwater until final remediation plans for the site were implemented.

In 1995 , the total uranium results from the monitoring wells in this program ranged from $280 \mu \mathrm{g} / \mathrm{L}$ to $1,490,000 \mu \mathrm{g} / \mathrm{L}$, all well above the $20 \mu \mathrm{g} / \mathrm{L}$ proposed drinking water standard for uranium. The metals and Volatile Organic Compound (VOC) sampling results for these wells showed detections of 1,1,1-trichloroethane, 1,1-dichloroethene, 1,2-dichloroethane, beryllium, cadmium, carbon tetrachloride, chromium, cyanide, lead, nickel, pentachlorophenol, selenium, and tetrachloroethene which were above the primary drinking water standards for these contaminants.

Even though the 1995 monitoring results show contaminant concentrations above the primary standards, the recommendation was made to the USEPA and the OEPA that this removal action be terminated. The recommendation was approved by the OEPA in September 1995, and by the USEPA in November 1995. 


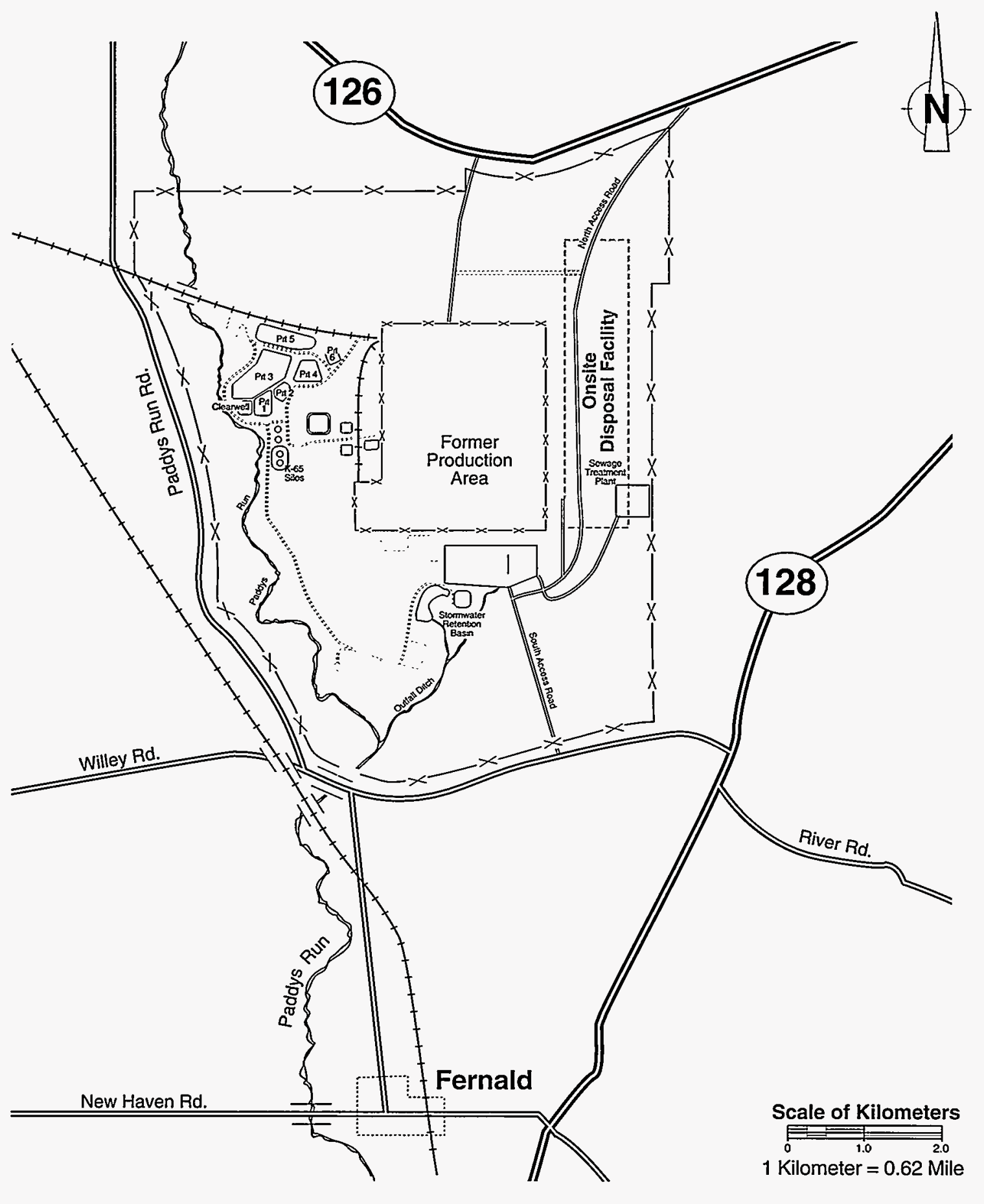

\section{LEGEND}

Onsite Disposal Facility

Plant Perimeter

Former Production Area Perimeter 
This recommendation was made because modeling performed for the Operable Unit 5 (OU5) RI/FS Reports showed that the natural resistance of the clay material between the perched groundwater and the aquifer provides a sufficient barrier to protect the aquifer during the time period required to implement the remediation of the contaminated soils and perched groundwater. Under the selected alternative for OU5, these contaminated zones of perched groundwater within the glacial overburden will be excavated, concurrent with soil remediation activities.

\section{Public Water Supply Program}

DOE has supplied bottled water to homeowners whose private wells have been impacted by the South Plume. This action is, however, considered only a temporary solution. The preferred alternative is to eliminate individual homeowner wells that withdraw water from the aquifer and to provide these residents with water from a public water supply.

The primary objective of this program is to protect public health by providing this permanent, reliable, and safe water supply to local residents. DOE has committed to providing its fair share of the cost for installation of the water mains in the South Plume area in the form of a grant to the Hamilton County Department of Public Works, the agency responsible for coordinating all water supply within Hamilton County.

The portion of this installation that is of particular interest to DOE involves approximately $23 \mathrm{~km}$ (14 miles) of water mains within Hamilton and Butler counties. This installation will occur along East Miami River Road from Bolton Water Works to the intersection of State Routes 126 and 128, then south along State Route 128 to approximately $2.7 \mathrm{~km}$ (1.7 miles) south of the New Haven Road intersection to Crosby Road. Installation will also occur along Willey, New Haven, Crosby Road and Paddys Run roads.

Construction of the main transmission and distribution lines mentioned above was completed in December, 1995. Construction of a 500,000 gallon reservoir located on Crosby Road was started in the fall of 1995, with construction activities to resume in early 1996, with estimated completion in June, 1996. The Fernald site will be the largest initial user of water when the system is completed. The entire system is scheduled for completion by the end of June, 1996.

\section{Archeological Findings}

Archeological investigations in support of the Public Water Supply project have revealed several significant sites and artifacts. Eleven sites have been discovered along the project right-of-way. Of these 11 sites, six were determined to be an extension of a large Fort Ancient village (the Schomaker Site). In addition, this site produced five human burials and a canine burial. Two other burials were dis- 
covered during construction of the pipeline. Other sites along the pipeline route revealed artifacts and features that provided significant information about the time frames of prehistoric Native American occupation in the Great Miami River valley. A total of 12,928 prehistoric artifacts, 1,750 historic artifacts, five prehistoric Native American burials and one prehistoric canine burial were recovered during archeological investigations associated with the Public Water Supply project.

\section{Establishing a Site Comprehensive Environmental Monitoring Program}

Implementation of groundwater remediation activities at the Fernald site requires that a groundwater quality management program be initiated to assess the performance of pump-and-treat activities, while at the same time monitoring the impact to the aquifer resulting from all other remediation activities (excavations, surface water controls, etc). Existing groundwater monitoring programs will be integrated into a comprehensive program that will better address the upcoming needs of the remediation. This comprehensive program will be defined in the Integrated Environmental Program Plan (IEMP) which will be presented to the USEPA and OEPA in 1996. Integration of the monitoring efforts will provide for more efficient reporting and data analysis efforts. The current Design Monitoring, Engineering Program Plan (DMEPP) for the South Plume will be the prototype monitoring program used for the integrated program.

Both the air and liquid pathways allow radioactive and non-radioactive materials to leave the Fernald site and are, therefore, monitored. The results from these monitoring activities are used to estimate potential radiation dose, which is discussed next in Chapter Seven. 


\section{ESTIMATED RADIATION DOSES FOR 1995}

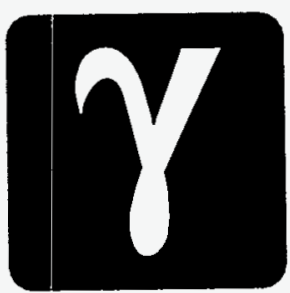





\section{Estimated Radiation Doses for 1995}

One of the primary public concerns about any facility that handles radioactive materials is that people working and living in the area may be exposed to harmful amounts of radiation. In response to this concern and environmental regulations, Fernald site personnel are monitoring the ways in which radioactive material could move through the environment and affect people. Background radiation levels and naturally occurring radioactive materials present technical as well as practical problems in trying to directly measure the dose people may actually receive from the Fernald site; therefore, scientists estimate dose using models and the results of environmental samples. This chapter provides the following information:

- An explanation of how dose estimates are calculated,

- Dose estimates from several different pathways for 1995, and

- An interpretation of the significance of these estimated doses.

\section{Results in Brief: 1995 Estimated Doses*}

\section{Air Pathway}

Airborne Emissions - The estimated maximum committed effective dose to a member of the public from 1995 airborne emissions was calculated as 0.19 mrem.

Foodstuffs - The committed effective dose from eating foodstuffs produced within three miles of the site was estimated to be $0.1 \mathrm{mrem}$.

Direct Radiation - There was no statistical difference between direct radiation measurements at the site fenceline and measurements at background locations. Therefore, no dose was attributed to direct radiation for 1995.

\section{Liquid Pathway}

Well Water - The estimated committed effective dose from drinking well water from the area around the Fernald site was 0.7 mrem.

Fish - The estimated committed effective dose from eating fish from the river near the Fernald site effluent line was .001 mrem.

* These doses for 1995 are also presented in Table 23 on page A-42. Information on doses received from other sources is also provided in that table. 


\section{Methodology for Calculating Total Radiation Dose}

DOE Orders and USEPA regulations require the Fernald site to demonstrate that its radionuclide airborne emissions are low enough to ensure that no one in the public receives an effective dose of 10 mrem or more in any one year. (This excludes radon-222 emissions, which are covered under different regulations. Radon regulations, emissions, and estimated dose from radon are presented in Chapter Eight of this report.) Moreover, to determine whether the site is well within the DOE dose limit to members of the public of 100 mrem per year from all exposure pathways, Fernald site personnel estimate doses from other components of the air and liquid pathways, as well as direct radiation dose from materials stored onsite. The DOE limit of 100 mrem per year from all pathways is the sum of the doses from radiation external to the body during the year plus the dose from radionuclides taken into the body during the year. This latter dose is called the committed effective dose and is received over a 50 -year period.

As described in Chapter One, pathways are the routes along which radioactive material moves and may deliver a dose to the public. Total dose estimates incorporate dose from the air and liquid pathways. Direct radiation is included as a component of the air pathway dose. Monitoring of the air and liquid pathways provides the basis for the extensive environmental sampling described in Chapters Four, Five, and Six. Using these measurements, a dose from each pathway can be estimated using models.

\section{Environmental and Dose Modeling}

The Fernald site, like many other nuclear facilities, uses models to estimate doses to the public. Models play an important role in environmental monitoring because current technology and the low concentrations of radioactive pollutants in the environment make it impractical to measure environmental doses with standard instruments. The nature of radioactivity and the presence of naturally occurring radioactive materials create difficulties in detecting low levels of radioactivity and distinguishing between natural radioactivity and radioactivity from the Fernald site. Models also estimate pollutant concentrations and doses which are below the detection capabilities of instruments and laboratory measurements. These concentrations and doses would be left out in assessing the environmental impacts of the site if models were not used. Environmental and dose models are briefly explained below.

Environmental modeling is a way to represent a complex environmental process, such as atmospheric dispersion of emissions or the air-to-soil-to-produce process, as a set of mathematical formulas. By studying an environmental process, such as dispersion of a pollutant from a stack as it is carried by the wind, scientists can develop a mathematical formula that models the process. They can then use this 
model to predict the concentration of the pollutant at a specific location. As additional processes are modeled, it is possible to interconnect them so that the movement of pollutants is predicted by a larger environmental model.

Dose models are developed similarly. By modeling radioactive decay, absorption and removal of radioactive materials in the body, and other physical and biological processes, scientists can develop a dose model to evaluate how radioactive materials deliver a dose. Connecting the dose model to the environmental model provides a means of estimating dose using information gathered through environmental sampling. Models are usually translated into computer programs to conveniently handle the data and calculations.

Although models may be the only comparative way for scientists to estimate dose, they do not necessarily predict all environmental processes. Because the mathematical formulas that represent the environmental and biological processes are simplifications and generalizations, applying them to the specific conditions at the site may lead to differences between predicted and actual concentrations or doses. The results or outputs of models always involve some uncertainty in the accuracy of the estimated dose, and many have built-in assumptions which strongly influence the results. Models may be most beneficial because of their ability to estimate the upper limit of the dose and identify the most influential pollutant or pathway of exposure.

Although the uncertainty associated with the radiation dose calculations has not been quantified, whenever Fernald-specific data were not available for parameter values (for example, food consumption values), conservative values were selected from research literature for use in the dose calculations. Thus, the estimated doses should be viewed as maximum estimates of potential doses resulting from Fernald releases.

\section{Air Pathway Dose Calculations}

The air pathway is a route for contaminants to reach people directly as emissions and indirectly through foods contaminated by airborne emissions. This section uses data from air and produce sampling as well as estimates of airborne releases (refer to Chapter Four) to calculate doses. Dose from radon is presented in the following chapter of this report.

\section{Estimated Doses from Airborne Emissions}

At the Fernald site, scientists obtain dose estimates from onsite airborne emissions measurements using a set of computer programs called CAP88-PC. The site uses CAP88-PC to determine compliance with the National Emission Standards for Hazardous Air Pollutants (NESHAP) requirements of the Clean Air Act. Within the programs, the AIRDOS (i.e., EPA dose model; MO79) program calculates 
concentrations of radionuclides in the air, on the ground, and in food based on estimates of the amount of airborne radioactive material released. The concentrations are then used to calculate the intakes and subsequent doses to people.

The CAP88-PC program calculates airborne radionuclide concentrations based on onsite airborne emissions measurements. The results from the fenceline ambient air monitoring stations are compared to the CAP88-PC concentrations, but are not used in inhalation dose calculations.

The CAP88-PC computer programs calculate both individual and collective doses. Collective dose is the sum of individual doses to people in the Fernald area and is reported in the units of person-rem. (For example, if 10 people each receive $1 \mathrm{rem}$, the collective dose is " 10 person-rem;" if 20 people each receive $0.5 \mathrm{rem}$, that collective dose also is " 10 person-rem.") The person-rem unit is used as a broad measure of the radiological impacts of the site and is useful in comparing the risks from site operations with other facilities and industries.

The CAP88-PC programs require a large amount of data to estimate dose, which includes the number, height, and location of release points; wind speed and direction; the amount of radioactive material released; and population distribution in the Fernald area. (Wind rose data summarizing wind speed and direction are shown in Figures 4 and 5 in Chapter One, and estimated airborne radionuclide emissions and population distribution are presented in Tables 2 and 24, in Appen$\operatorname{dix}$ A.) Although some of the data were obtained through measurements and sampling, many were not readily available and were estimated. Examples of estimated data are the amounts of airborne radioactive material released from the Laboratory Building and the Cooling Tower. The site made very conservative estimates for these and all other emission sources which were not measured directly. Conservative estimates, used frequently in environmental monitoring and dose calculations, are based on assumptions about an exposure situation that should result in the highest estimate of a dose. For example, an assumption about estimated doses at the air monitoring stations is that a person is outdoors at one location for $100 \%$ of the time during the year. The assumptions are conservative in the sense that they provide a margin of error for underestimating emissions and doses. Conservative estimates of emissions are used to ensure that dose estimates are not underestimated but are the maximum doses that could have resulted from site operations during 1995.

Results of the CAP88-PC programs estimated the maximum effective dose from 1995 airborne emissions to be 0.19 mrem to a person located east-southeast of the former production area. This dose estimate assumed that the person remained outside his or her home $100 \%$ of the time in 1995. The dose was well below the NESHAP standard of 10 mrem from the air pathway and was only $0.19 \%$ of the DOE guideline of 100 mrem per year from all pathways (see Figure 47). 
Figure 47: Department of Energy Dose Limits

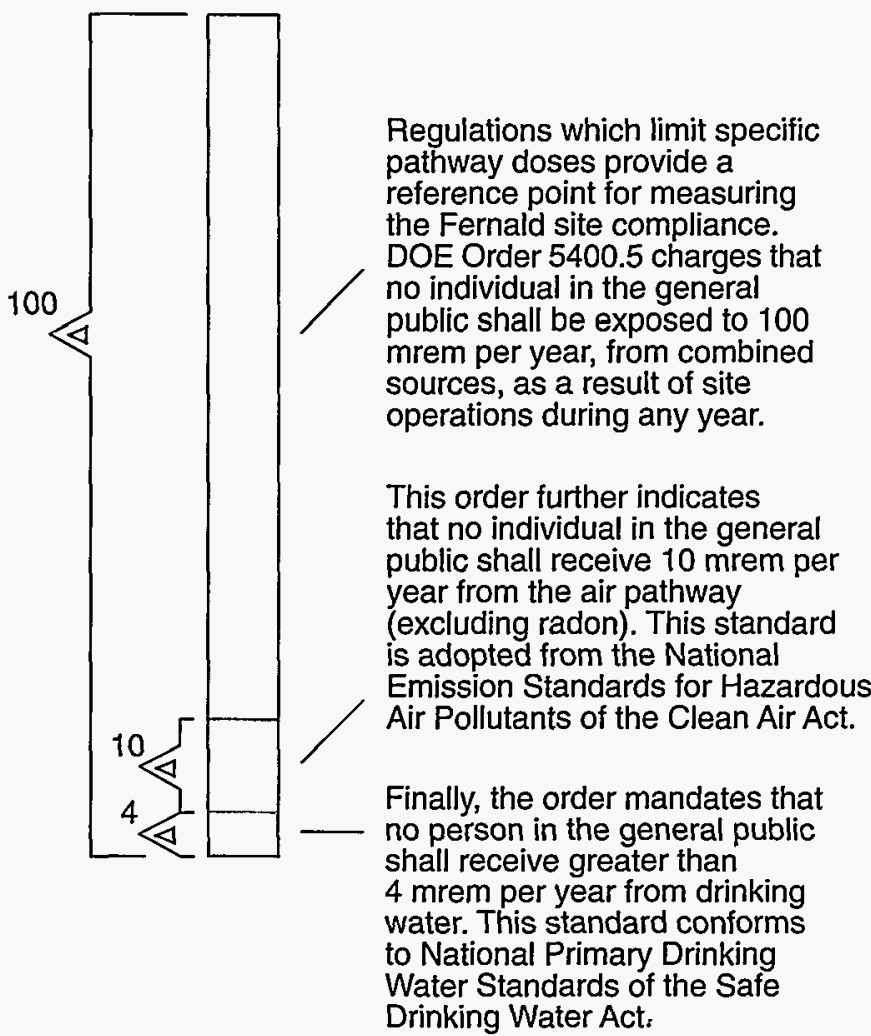

The collective effective dose from 1995 airborne emissions (not including radon) to the population within $80 \mathrm{~km} \mathrm{(50}$ miles) of the site was also calculated by CAP88-PC. This dose was estimated to be 4.4 person-rem for a population of $2,740,000$. For comparison, the same group of people received an estimated collective effective dose of 300,000 person-rem from background radiation, excluding radon.

\section{Estimated Dose from Eating Foodstuffs Produced near the Fernald Site}
Because the CAP88-PC program only calculated doses from 1995 airborne emis- sions, scientists made additional dose cal- culations to estimate doses from past emissions that may have accumulated through the food chain. These additional calculations estimate potential dose from consuming locally grown fruits, veg- etables, and milk.

Uranium deposited in soil during the years the Fernald site was in production may be absorbed by produce and farm animals and, therefore, deliver a secondary pathway dose. This estimated dose is based on the conservative assumption that $100 \%$ of a person's diet of fruit, vegetables, and milk comes from gardens and farms in the Fernald area. This modeled diet assumes an annual consumption of $18 \mathrm{~kg}$ (40 lbs) of leafy vegetables (cabbage, lettuce, etc.), $45 \mathrm{~kg}$ (100 lbs) of grains (corn, soy beans, wheat, etc.), $68 \mathrm{~kg}$ (150 lbs) of fruit, $28 \mathrm{~kg}$ (62 lbs) of belowground vegetables (potatoes, carrots, etc.), $45 \mathrm{~kg}$ (100 lbs) of other vegetables, and 112 liters ( 30 gallons) of milk. ${ }^{36}$ To represent the foods in the diet, scientists analyzed cabbage, corn, soybeans, apples, potatoes, tomatoes, green beans, and milk sampled from local gardens and farms for uranium. The maximum uranium concentration found in locally produced foods was used to estimate dose. The average background uranium concentration in foods was subtracted from the maximum concentration to account for the natural occurrence of uranium in foods.

The laboratory analysis of foodstuffs determines the total amount of uranium (all uranium isotopes) in the sample. Because any dose from uranium is based on the isotopic composition of uranium, an assumption about the isotopic composition of uranium in foodstuffs must be made to calculate the dose. Scientists assume any uranium detected in the foodstuffs has the isotopic composition of natural ura- 
nium. This assumption is reasonable because a large amount of uranium produced at the Fernald site had an isotopic composition similar to naturally occurring uranium. Scientists used dose conversion factors to convert the intake of uranium to dose. The conversion factors themselves are the result of modeling the radioactive decay and metabolism of radionuclides in the body. ${ }^{37}$

The committed effective dose received over the course of 50 years was calculated to be $0.1 \mathrm{mrem}$, only $0.1 \%$ of the DOE dose limit of $100 \mathrm{mrem}$ per year for all pathways. This dose is comparable to the estimated doses from foodstuffs in past years.

\section{Direct Radiation Dose}

Unlike the air and liquid pathways where a radionuclide in the form of a particulate or gas delivers its dose after inhalation or ingestion, direct radiation dose is the result of radiation (gamma and $\mathrm{X}$-rays) emitted from radionuclides stored onsite. The largest sources of direct radiation are the wastes stored in the K-65 silos and thorium compounds stored at several locations onsite. Direct radiation dose is estimated using environmental thermoluminescent dosimeters (TLD) measurements (see Chapter Four), rather than through the use of models.

Direct radiation dose was estimated using the highest dose from the twelve fenceline monitoring locations (see Table 10 on page A-14) and subtracting the average dose measured at six background TLD locations (locations 18, 19, 20, 21, 30 , and 33 as shown in Figure 30 on page 95). Limits in the precision on TLD data and variations in natural background radiation require consideration of the uncertainty (the plus/minus [ \pm ] values) associated with each measurement in calculating dose. The uncertainty is calculated for a $95 \%$ confidence interval ( 2 sigma) around the average.

\section{Comparison of Fenceline and Bacikground Doses}

A comparison of the highest fenceline dose to the average background dose is shown below. From the figure, it is clear that the highest fenceline dose is largely within the range of the average background dose. This overlap of the doses means that, at the $95 \%$ confidence level, the doses are not statistically different from one another.

$\frac{61.8}{70 \pm 8.2 \mathrm{mrem}}$ Range of maximum fenceline dose

$63 \pm 12 \mathrm{mrem}$

51
Range of average background dose
75 
From the data in Table 10, the highest 1995 fenceline dose occurred at location 6 and is $70 \pm 8.2 \mathrm{mrem}$ per year ( 2 sigma). The average background dose from locations $18,19,20,21,30$, and 33 is $63 \pm 12$ mrem per year. At first glance, it appears that the direct radiation dose would be 10 mrem per year above background at the site fenceline. However, when the range of the background dose measurements is taken into account, there is no statistical difference between the fenceline dose and the average background dose. The data indicate that the highest fenceline dose is between $61.8 \mathrm{mrem}(70-8.2)$ and $78.2 \mathrm{mrem}(70+8.2)$ per year, while the average background dose is between 51 mrem (63-12) and 75 mrem $(63+12)$ per year.

Because the range of background and the range of fenceline doses overlap, there is no firm basis for stating that there is a difference between the fenceline and average background doses. Given this lack of statistical difference between the doses, no dose was attributed to direct radiation for 1995. TLD results from fenceline locations do not show any increasing or decreasing trends over the past five years.

\section{Liquid Pathway Dose Calculations}

Dose estimates from the liquid pathway are calculated using environmental sample results and dose conversion factors. Measurements of radionuclide concentrations in groundwater, the Great Miami River, and fish from the river are used to estimate dose from the liquid pathway. Descriptions of the monitoring programs for these environmental samples are given in Chapters Five and Six.

\section{Estimated Dose from Drinking Well Water in the Area around the Fernald Site}

As discussed in Chapter Six, the site monitors a number of private drinking water wells for uranium contamination. While most wells have uranium concentrations which are within the 0.07 to $2 \mathrm{pCi} / \mathrm{L}(0.1$ to $3.0 \mathrm{ppb})$ range of background concentrations, several wells have higher concentrations and are considered to be a source of dose from the site. ${ }^{31,32}$

In order to estimate dose from drinking well water in the area around the site, the average uranium concentration in wells located north and west of the site was subtracted from the maximum concentration found in wells located south and east of the site. Data from wells $3,4,10,22$, and 30 were used to provide the average background concentration. The maximum concentration in a drinking water well south and east of the site was found in Well 39. For the purpose of dose calculation, the uranium in Well 39 is assumed to have the isotopic composition of natural uranium. Using a consumption rate of 2 liters ( 0.5 gallon) of water per day, the committed effective dose received from drinking water from Well 39 would be 0.7 mrem per year. 


\section{Estimated Dose from Drinking Great Miami River Water}

Although the Great Miami River downstream of the site is not designated as a public water supply by OEPA, the site estimated the radiation dose to an individual if that person drank only the water from the river downstream of the discharge point after mixing had occurred.

Scientists used data on the amounts of radionuclides discharged to the Great Miami River (see Table 11 on page A-15) and the average river flow to calculate concentrations in river water. Dose conversion factors were used to convert the intake of radionuclides to dose. Assuming a daily consumption of 2 liters ( 0.5 gallon) of water, the committed effective dose from Fernald releases received over the course of 50 years would be 0.01 mrem. $^{36}$

\section{Estimated Dose from Eating Fish from the Great Miami River}

The estimated dose from eating fish from the river was calculated using the maximum uranium concentration in edible fish collected at River Mile (RM) 19 and RM 24 (see Figure 35 on page 105). The average background uranium concentration in edible fish collected at RM 38 was subtracted from the maximum concentration to account for natural occurrence of uranium in the fish. As with other dose calculations, any uranium detected in the fish was assumed to have the isotopic composition of natural uranium.

Assuming an annual consumption of $4.5 \mathrm{~kg}(10 \mathrm{lbs})$ of fish from the Great Miami River, the committed effective dose would be 0.001 mrem. ${ }^{36}$ This dose is well below the DOE guideline of 100 mrem effective dose per year from all pathways.

\section{Total of Doses to a Maximally-Exposed Individual}

Figure 48: Dose to Maximally-Exposed Individual, $1991-1995$

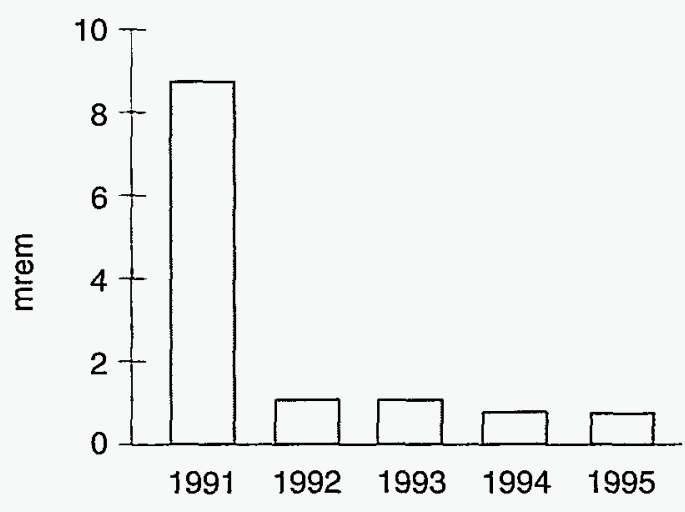

The maximally-exposed individual is a hypothetical member of the public who receives the highest calculated effective dose based on the location of his or her home, weather conditions, and the individual pathway doses. Because it is not possible to single out a specific individual in the Fernald area who receives the most dose, the results of the individual pathways and the CAP88-PC evaluation are added to predict the maximum dose that a person could receive. The dose to the maximally-exposed individual is a total of estimated doses from breathing 1995 airborne emissions (excluding radon), consuming foodstuffs produced in the Fernald area, drinking water from a well in the Fernald area, eating fish from the Great Miami River, and re- 
ceiving the direct radiation dose above background at the site fenceline. The conservative assumptions used throughout the dose calculation process ensure that the dose to the maximally-exposed individual is the upper limit of the actual dose any member of the public receives.

The 1995 dose to the maximally-exposed individual is estimated to be $0.1 \mathrm{mrem}$, well below the guideline of 100 mrem per year for all pathways. Figure 49 shows the doses to the maximally-exposed individual from 1991 to 1995.

\section{Significance of Estimated Radiation Doses for 1995}

One method of evaluating the significance of the estimated doses is to compare them with doses received from background radiation (see Chapter Two). Background radiation yields approximately 100 mrem per year from natural sources, excluding radon. Comparing the maximally-exposed individual dose to the background dose demonstrates that, even with the conservative estimates, the dose from the site is much less than background. Although the estimated dose will be received in addition to the background dose, this comparison provides a basis for evaluating the significance of the estimated doses. A dose that is small in comparison to that of background radiation will produce no measurable health effects.

Another method of determining the significance of the estimated doses is to compare them with dose limits developed to protect the public. The International Commission on Radiological Protection (ICRP) has recommended that members of the public receive no more than 100 mrem per year as a result of site operations, and DOE has incorporated this limit into Order 5400.5 as well. The sum of all estimated doses from site operations for 1995 was well within this limit.

Dose to Maximally-Exposed Individual

\begin{tabular}{|c|c|c|}
\hline Pathway & $\begin{array}{l}\text { Dose Attributable } \\
\text { to the Site }\end{array}$ & Applicable Guideline \\
\hline \multicolumn{3}{|l|}{ Air } \\
\hline Estimated 1995 emissions & $0.19 \mathrm{mrem}$ & 10 mrem/air \\
\hline Foodstuffs grown in Fernald area & $0.1 \mathrm{mrem}$ & 100 mrem/all pathways \\
\hline Direct radiation & 0.0 mrem & 100 mrem/all pathways \\
\hline \multicolumn{3}{|l|}{ Liquid } \\
\hline Well water in the Fernald area & 0.66 mrem & 4 mrem/drinking water \\
\hline Fish from Great Miami River & 0.001 mrem & 100 mrem/all pathways \\
\hline Maximally-exposed individual & $\sim 0.1 \mathrm{mrem}$ & $100 \mathrm{mrem} /$ all pathway \\
\hline
\end{tabular}


Radon is subject to different regulations than other components of the air pathway. Likewise, the dose received from radon is regulated separately. Therefore, the Radon Monitoring Program is discussed separately in the next chapter, as well as the dose received from radon at the Fernald site. 


\section{THE RADON MONITORING PROGRAM}

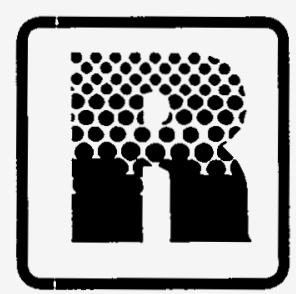




\section{The Radon Monitoring Program}

Radon is a radioactive gas, with three naturally occurring isotopes: Rn-222, or radon; Rn-220 or thoron; and Rn-219 or actinon (for purposes of clarity, throughout this chapter, the term "radon" will refer only to Rn-222). Each is a member of one of the natural decay chains shown in Figure 49. These gases escape from the earth's crust to the atmosphere and are inhaled, resulting in a potential internal radiation exposure. As discussed in Chapter Two, this radon radiation dose is considered part of the natural background exposure, contributing to approximately $55 \%$ of a person's average annual dose.

\section{Results in Brief: 1995 Radon Monitoring}

Fenceline Concentrations - The average fenceline concentration measured in 1995 was approximately $0.7 \pm 0.4 \mathrm{pCi} / L$, which is well below the DOE limit of $3.0 \mathrm{pCi} / \mathrm{L}$. The 1994 average concentration was approximately $0.8 \mathrm{pCi} / \mathrm{L}$.

Background Concentrations - The average background concentration measured in 1995 was approximately $0.7 \pm 0.1 \mathrm{pCi} / \mathrm{L}$. The 1994 average background concentration was approximately $1.3 \mathrm{pCi} / \mathrm{L}$.

Fenceline dose attributable to radon and its daughters - The calculated dose at the fenceline in 1995 was estimated to be 504 mrem, utilizing the methodology used by the National Council on Radiation Protection (NCRP). The fenceline dose in 1994 was 576 mrem. Measured background concentrations did not differ from the Fernald fenceline concentrations. Therefore, no discernable dose can be attributed from Fernald site sources.

The data are based on alpha track-etch detectors placed in the field for six-month periods. Prior to 1995, these detectors were in the field for three months before being exchanged. Leaving them in the field for longer periods of time increases the accuracy of the measurement. 


\section{Introduction To Environmental Radon}

Every person living on earth is exposed to radon at varying concentrations, depending upon the local geological conditions. The short half-lives of actinon ( $\sim 4$ seconds) and thoron ( $\sim 55$ seconds), limit their movement in the environment. However, radon has a sufficiently long half-life ( $\sim 3.82$ days) to permit considerable movement into the environment. Therefore, for purposes of dose estimates, radon is the only significant contributor of the three isotopes. However, the dose individuals receive is not due to just radon because it quickly decays into more radioactive material, known collectively as daughter products (polonium-218, lead-214, bismuth-214, and polonium-214).

As radon decays, electrostatically charged particles known as alpha particles are produced, as well as radioactive daughters, which become attached to airborne dust particles. A person inhales this dust, which may become deposited inside the lungs. This is where the radiation exposure occurs. Attached daughter products decay within the lung releasing more charged alpha particles. These charged particles can damage the cells lining the air passages and deliver the bronchial radiation dose implicated in bronchiogenic carcinoma. Most of the damage is due to the high energy alpha particles given off by the decay of polonium-218 and polonium-214. Ironically, radon itself accounts for very little of the dose because it does not react chemically - what you inhale you will most likely exhale. The daughter products' alpha particles deliver the dose.

Many factors can affect the concentration of radon in the environment, including the distribution of uranium in the earth's crust, porosity of the soil, local weather conditions, etc. Because these conditions are not constant, the concentration of radon in the atmosphere shows daily, seasonal, and annual variability. These changes are caused, in part, by atmospheric conditions. Local rainfall or snowcover limits radon's ability to escape from the ground. Extreme temperatures also influence the rate at which radon escapes from the ground due to ground temperature changes. During periods of calm winds and temperature inversions, warm air traps cooler air near the earth's surface, minimizing air mixing. When these inversions occur, radon's movement is limited, and as a result, concentrations tend to increase. In addition, radon is relatively soluble in water. Water transport has been a significant mechanism for migration of radon into some homes where groundwater (well water) is used instead of surface water. 


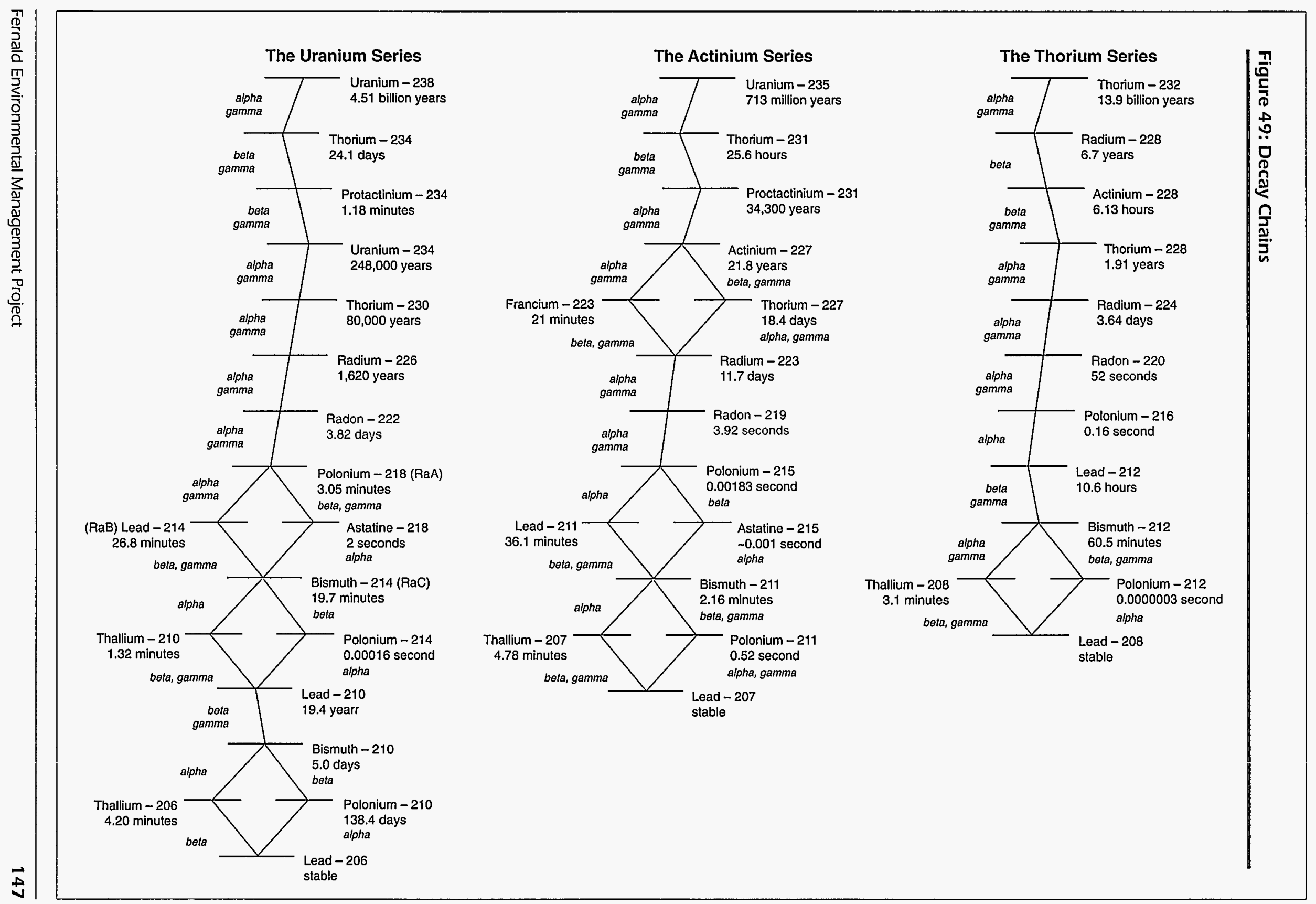




\section{The Radon Monitoring Program at Fernald}

In addition to the radon found naturally in the environment, Fernald stores some radioactive materials onsite that generate radon. The primary source of radon is from the radium-bearing material stored in the K-65 silos. Six Waste Pits and the Thorium Warehouse (Building 65) are potential or relatively small radon sources. Because of these sources, the Radon Monitoring Program has monitored levels since the early 1980s to assess the impact on the public and the environment. Monitoring results and dose estimates are reported separately from the air pathway in order to clarify information and regulations that are unique to radon.

This program operates in compliance with the requirements of DOE Order 5400.5, Radiation Protection of the Public and the Environment. This order provides guidelines for radon concentrations and emissions in the atmosphere above facility surfaces or openings. It defines radiological protection requirements and guidelines for cleanup of residual radioactive material, the management of resulting wastes and residues, and the radiological release of property. These requirements and guidelines are applicable at the time the property is released and state that radon levels above interim storage facilities must not exceed the following limits when added to background levels:

- $100 \mathrm{pCi} / \mathrm{L}$ at any given point,

- Annual average concentration of $30 \mathrm{pCi} / \mathrm{L}$ over any facility site,

- Annual average concentration of $3 \mathrm{pCi} / \mathrm{L}$ at or above any location outside the facility site, or

- Flux rates greater than $20 \mathrm{pCi} / \mathrm{m}^{2}$ per second from the storage of radonproducing wastes.

The Environmental Radon Monitoring Program at Fernald utilizes two types of radon detectors to measure radon concentrations in the environment: long-term time integrating alpha track-etch detectors and continuous alpha scintillation monitors.

\section{Long-term, Time-integrating Radon Monitoring}

An alpha track-etch detector consists of a plastic cup containing a special plastic chip with a filter over the top. Radon in the atmosphere passes through this filter. If the radon decays near the plastic chip, its alpha particles can penetrate the chip. This penetration causes a damaged track in the plastic, which can be made visible by chemical etching. The number of visible tracks is proportional to the number of alpha particles that have penetrated the plastic. This number is related to the average concentration of radon in the cup.

Each radon measurement contains three components: (1) the local natural background radon contribution; (2) the etches present in the plastic before field placement (known as detector background); and (3) the potential Fernald radon 
contribution. The second component is easily measurable by submitting unexposed detectors for counting. Unfortunately, at a specific location, it is impossible to distinguish between the first and third components. Therefore, to determine the radon contribution from Fernald sources, the average background value for all offsite background locations is subtracted from each gross radon measurement to determine a net radon concentration.

\section{Routine Long-term Monitoring}

Alpha track-etch detectors are used when monitoring requirements pertain to annual limits because they consider data over periods of time and provide an overall average concentration. The cups are placed on- and offsite to gather both background and site-specific information regarding the dispersion of radon from Fernald sources. Currently, there are approximately 55 locations, with each location containing either two or three detectors. At the site boundary, the Environmental Radon Monitoring Program evaluates data from 20 locations. Data are collected from three area residences and six background locations shown in Figure 50. Detectors were also used to measure radon concentrations adjacent to the silos and in the most common wind direction from the silos as shown in Figure 51.

\section{Continuous Radon Monitoring}

Alpha-scintillation detectors utilize special cylindrical containers known as Lucas cells to continuously monitor radon concentrations. This technique can be either active or passive sampling. Environmental data is collected using passive method. During the passive measurement, radon passes through a foam barrier into the Lucas cell. The foam functions similarly to the filter placed on the alpha tracketch detectors mentioned previously. The inside surface of the detector cell is coated with a crystalline material known as zinc sulfide. Alpha particles generated from radon and its daughters produced within the cell react with the zinc sulfide crystals producing light pulses. These light pulses pass through the cell and enter a photo multiplier tube. This instrument turns the light signal into an electronic signal, the strength of which corresponds to a specific concentration of radon within the cell.

Determining a radon concentration involves evaluation of the three components of the measurement recorded by the radon monitor: (1) natural background radon concentration from the area, (2) the electronic signal contribution to the reading plus the cell background (electronic noise), and (3) potential contributions of radon from Fernald.

In a radon-free environment, the continuous monitor will record a signal, falsely indicating a radon concentration. This electronic noise phenomenon is common to all types of electronic instrumentation. At this time, radon data collected at Fernald are not corrected for electronic noise. Therefore, all data are conservative in that the true value is less than the recorded value. Studies are ongoing to deter- 
Figure 50: Selected Offsite and Fenceline Radon Monitoring Locations

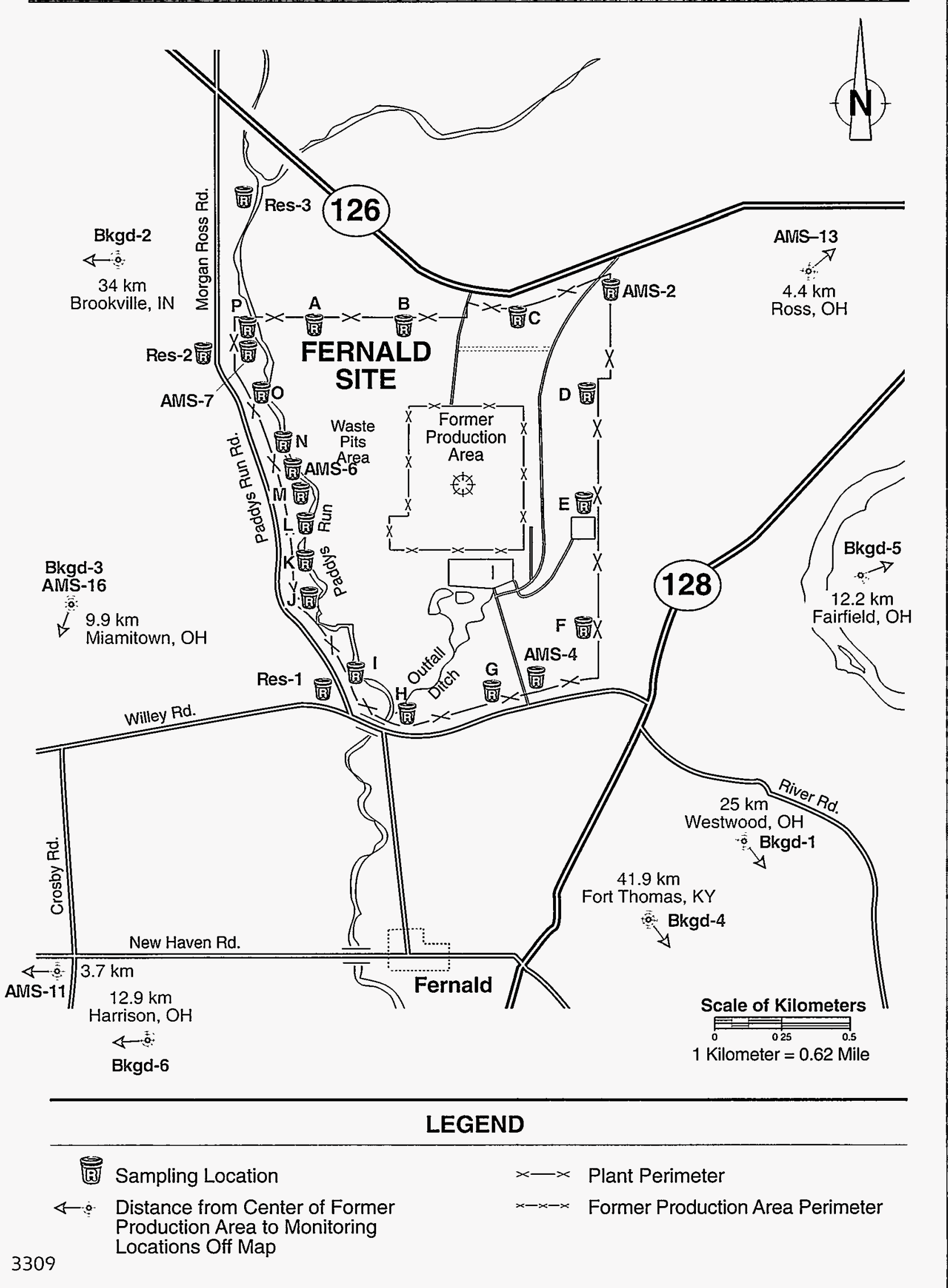




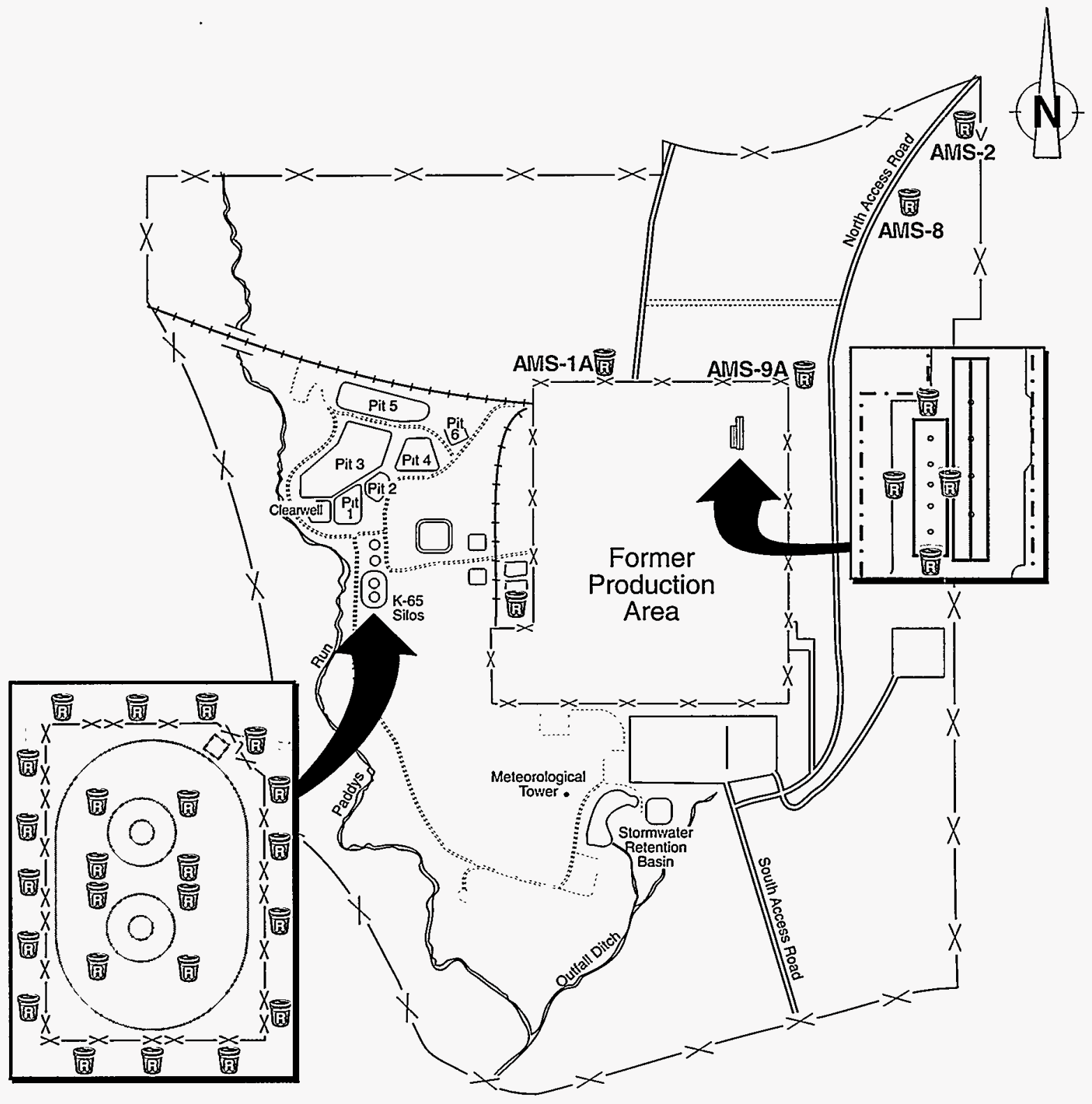

Scale of Kilometers

1 Kilometer $=0.62$ Mile

\section{LEGEND}

通 Onsite Locations

$\times-\times x$ K-65 Silos Area Perimeter

$\times-\times$ Plant Perimeter

$x-x-x$ Former Production Area Perimeter 
mine the variability in the electronic noise portion of recorded data and its stability over time. Once studies are complete, an electronic noise background value may be used for each instrument. To determine the background environmental radon concentration, a similar process is employed as in the alpha track-etch section.

Continuous monitors reveal important information regarding the dynamics of radon concentrations on- and offsite. These monitors allow for timely review of radon concentrations, which may indicate they are changing significantly from day-to-day and week-to-week. However, there are certain restrictions to using these monitors. Electrical power is available from a limited number of locations. Additionally, extreme cold weather affects the reliability of the instruments and some of the data are rendered unusable.

\section{Routine Continuous Monitoring}

Removal Action No.4 requires monitoring of the radon concentration in the headspace of each $\mathrm{K}-65$ silo be performed on a continuous basis until the radiumbearing materials inside are removed. Accordingly, Fernald summarizes this monitoring data into the FFCA report which is submitted to USEPA. This monitoring technique is considered active sampling because it uses a pump to collect the sample.

Continuous monitoring was conducted at select fenceline locations as well as various locations onsite. The locations of these monitors are shown in Figure 52 on the next page.

\section{Special Project Monitoring}

During 1995, radon monitoring was conducted at Waste Pit 1 and Waste Pit 3 in support of excavation activities for the Operable Unit 1 Dewatering Excavation Evaluation Program (DEEP). For dry trenching activities at Waste Pit 1, excavations were made in a large trench while maintaining nearly vertical walls. Excavation was carried out to a depth of approximately 15 feet. Two radon monitors near the perimeter of the excavation were placed in the predominant wind direction, and another monitor was placed in the least predominant wind direction to serve as a field background. Slightly elevated radon concentrations (typically 1-5 $\mathrm{pCi} / \mathrm{L}$ ) were measured when the trench was being excavated.

At Waste Pit 3, a ramp was added to the excavation of a hole. The purpose of this ramp was to determine if tracked excavation could operate on the sludge waste materials in the pit. The ramp was 20 -feet wide and excavated at a 12-degree angle. The excavation depth was slightly less and a 30-foot diameter circular pit floor was excavated. Radon monitors were placed in a similar configuration around the excavation. Similar to Waste Pit 1 measurements, slightly elevated (typically $1-5 \mathrm{pCi} / \mathrm{L}$ ) radon concentrations were observed when the ramp was 
Figure 52: Selected Continuous Radon Monitoring Locations

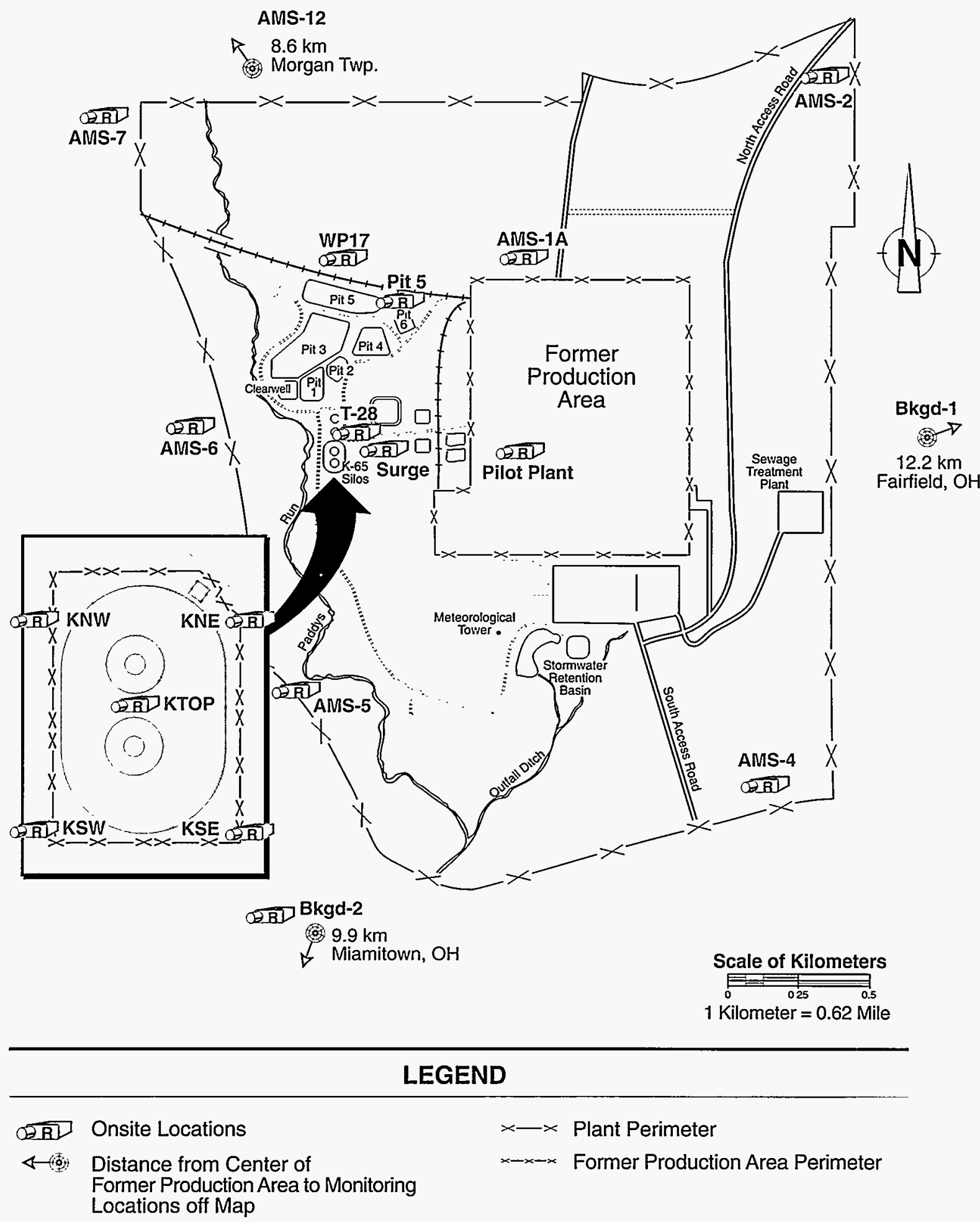


being excavated. All measured increased radon concentrations were significantly less than the annual DOE limits of $30 \mathrm{pCi} / \mathrm{L}$ over a storage facility site. The impacts of these activities were not observable at the property fenceline and no measurable offsite releases were observed.

\section{Environmental Radon Monitoring Results}

Alpha track-etch results for 1995 are provided in Table 25 on page A-45. Comparison of annual average radon concentrations at the six background locations to the 20 fenceline locations does not indicate any measurable contribution at the fenceline from Fernald sources. Average fenceline radon concentration was $0.7 \pm$ $0.4 \mathrm{pCi} / \mathrm{L}$ and was considerably less than the $\mathrm{DOE}$ limit of $3.0 \mathrm{pCi} / \mathrm{L}$. The range of values for any location on the fenceline varied from $0.5 \pm 0.1 \mathrm{pCi} / \mathrm{L}$ to a maximum of $1.1 \pm 0.2 \mathrm{pCi} / \mathrm{L}$, excluding unqualified results. The maximum measurement was still considerably less than the DOE limit.

The average background radon concentration as measured by the alpha track-etch monitors was $0.7 \pm 0.1 \mathrm{pCi} / \mathrm{L}$. The concentration for any of the background locations varied from less than $0.6 \pm 0.4 \mathrm{pCi} / \mathrm{L}$ to a maximum of $0.7 \pm 0.5 \mathrm{pCi} / \mathrm{L}$.

\section{Uncertainties With Environmental Measurements}

At the low concentrations of radon observed at environmental levels, the range of values observed is likely to vary from the true measurement by a substantial amount. For instance, background radon concentrations, which vary by geographical area, differ by as much as $50 \%$ of the typical range of environmental data. At these low concentrations, it is difficult to identify contributions from external sources compared to natural background concentrations. Significant contributions, however, are detectable. This fact is due to environmental concentrations being near the lower detection limit of the detector. Accuracy for the cups collected over several years based on the site's and the vendor's data indicates that deviation from a true value can range up to $\pm 25 \%$.

Additionally, the uncertainty of a radon detector measurement is inversely proportional to the concentration and to the time of exposure. As the concentrations and/ or time of exposure increase, it is more likely that measured values will approximate the true value. For example, if a reading of $10.0 \pm 0.1 \mathrm{pCi} / \mathrm{L}$ was recorded, the uncertainty represented would be $1 \%$. If the reading for the same exposure period was $1.0 \pm 0.1 \mathrm{pCi} / \mathrm{L}$, the uncertainty would be $10 \%$. Figure 53 graphically represents this situation.

Extending the length of time alpha track-etch detectors are placed in the field can also reduce uncertainty in that the exposures will be higher. Recent research recommends environmental monitoring exposure periods from 3 to 12 months. Longer monitoring exposure periods would increase the likelihood that data 


\section{Figure 53: Measurement Uncertainty}

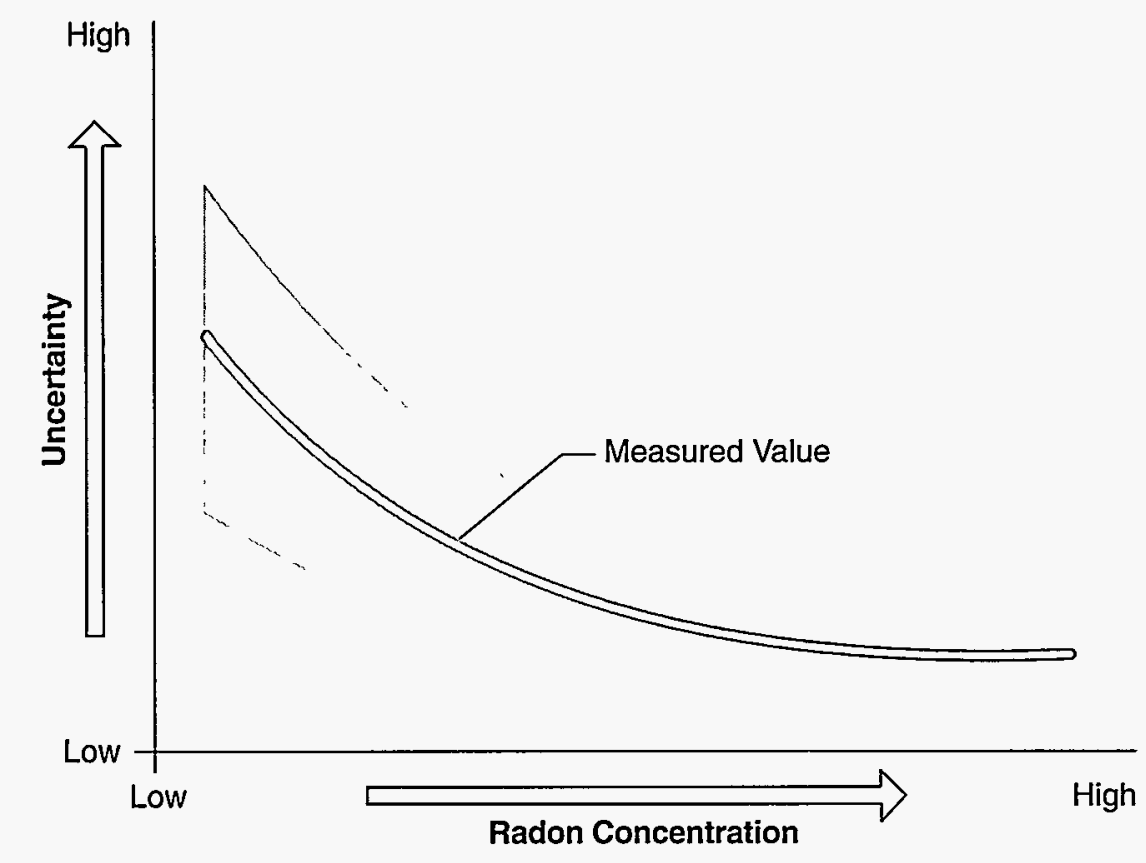

would be produced that could more accurately be measured. Current quality assurance practices include vendor analysis of radon detectors subjected to a low radon exposure. Quality assurance practices include vendor analysis of a radon detector subjected to a lower radon exposure. Spiking radon cups at higher known radon exposure would also help determine the certainty of measurements at the low radon exposures, because the results are more variable at low radon exposures and would improve with higher exposures.

\section{Quality Assurance of the Radon Monitoring Program}

Environmental monitoring of radon provides many challenges. Ideally, instrumentation is required to be rugged, weather-resistant, portable, reliable, and able to measure extremely low concentrations of radon. Each of the two monitoring methods utilized by the radon monitoring personnel include some but not all of these ideal requirements.

Each year the monitoring program is evaluated and areas of potential improvement are identified to enhance or upgrade the program. In regard to continuous monitoring, the obvious problem is the confirmation that the instrument background of the monitor does not vary throughout the year. When a monitor is calibrated, the vendor typically provides information regarding the instrument background. This background value represents data recorded when a monitor operates in a radon-free environment. As referred to previously, this is the "electronic noise" of the instrument. This value can easily be programmed into the instrument to provide a net radon concentration measurement accounting for the instrument background. This subtraction process is essentially the zeroing of the monitor.

Since it has been noted over time that the performance of the monitors is affected by the environment during the instrument's year-long calibration performance period, testing is ongoing to ensure the background reading of the instrument is 
stable. If the instrument background varied, it would be possible that lower radon concentration data would ultimately be reported. This happens because some constant value would always be subtracted from the instrument readings. If it is confirmed that instrument background is not adversely affected by environmental conditions, this data will be appropriately subtracted from each instrument, and a representative lower net radon concentration will be produced in future results.

The foremost problem associated with alpha track-etch detectors is the uncertainty of results at low exposures (e.g., $100 \mathrm{pCi} / \mathrm{L}$-days). In the past, there have been examples of blank data (non-exposed detectors) showing higher exposure than "spiked" detectors (detectors that should record background exposure plus the additional known spiking exposure). This phenomenon still occurs. Background detectors, those never placed in the field, have read in the vicinity of $170 \mathrm{pCi} / \mathrm{L}$ days exposure for the time frame where detectors that were substantially spiked may only read $130 \mathrm{pCi} / \mathrm{L}$-days exposure. Theoretically, these detectors should read higher than blank detectors because the exposure measured on them is that of background plus the spiking exposure.

Conditions that may cause this variability in the results are: storage of unexposed detectors for up to a year in an offsite building (background exposure builds up before detectors are used), and using detectors from more than one lot number. Solutions for this problem may include procuring detectors just before use in the field. This also may eliminate any background buildup, therefore eliminating the problems of comparing data obtained from different lot numbers since smaller quantities will be purchased at one time. The sensitivity of detector material varies due to thickness and temperature fluctuations during material production. Also, acquired background exposure during storage can also influence the sensitivity.

The analytical vendor for the alpha track-etch detectors participates in the Environmental Protection Agency's Radon Monitoring Program testing and meets the quality assurance requirements. Exposure ranges for testing have been between $180 \mathrm{pCi} / \mathrm{L}$-days to $2,000 \mathrm{pCi} / \mathrm{L}$-days. In addition, the vendor has conducted quality assurance tests at exposures less than $100 \mathrm{pCi} / \mathrm{L}$-days and noticed some variability of data that we have experienced. Data at higher exposures are much more precise. The annual DOE limit for property fenceline exposures would be approximately $1,100 \mathrm{pCi} / \mathrm{L}$-days ( 365 days $\mathrm{x}$ an average daily concentration of $3 \mathrm{pCi} / \mathrm{L}$ ). Although much variability is observed at our low semi-annual exposures, the data are clearly below the annual exposure limits with respect to both exposure and annual average concentration limits.

Table 25, which summarizes data collected during 1995, provides some interesting results. During the second half of the year, some data gathered were nonrepresentative and erroneously high. (Questionable data are annotated with a superscript $\mathrm{b}[\mathrm{b}]$ in the table.) Upon examination, data reflect the problems with storing the detectors for long periods of time before use. It appears the detectors in 
question came from a storage bag that was only semi-permeable to radon. The indoor concentrations of radon where the detectors are stored were several times higher than the outdoor concentrations measured. Confirmation was obtained by examining continuous monitoring data from nearby monitoring locations. This data represented radon concentrations of less than $1.0 \mathrm{pCi} / \mathrm{L}$ which was in agreement with both historical data and data from other locations.

Table 25 also represents the relative precision of the detectors. As a quality assurance measure, the vendor receives the detectors that are assigned a random number so they have no idea whether the detectors were placed in the field or were spikes or blanks. When the data are grouped together and analyzed later, one can see that the replicate detectors at each location measure nearly the same radon concentrations. This is represented by the low $+/$ - values associated with the average concentration at each location. A review for representation and validity is conducted to ensure quality data are presented in this report.

\section{Estimated Fenceline Radiation Dose from Radon}

The radiation dose from radon is estimated utilizing a method used by the National Council on Radiation Protection (NCRP) ${ }^{38}$ In 1995, the dose from radon was estimated to be 504 millirem (mrem). This dose was calculated from the average annual fenceline radon concentration recorded using the alpha track-etch cups. The table on the next page presents the 1995 fenceline dose estimates, including the $\mathbf{2 0 0}$ mrem average background contribution mentioned in Chapter Two.

The 1995 dose estimate assumed the offsite ambient radon-to-radon daughter concentration was 0.7 . This ratio for ambient outside air is in accordance with a national, widespread sampling referenced in the NCRP report. Actual values for radon daughters have not been measured at offsite or fenceline monitoring locations. A rigorous monitoring program would need to be developed to account for seasonal and spatial variations. This type of monitoring would produce an average value equilibrium ratio. It is likely this value would be similar to the average values referenced in the NCRP report.

The dose estimate also assumes that the dose was calculated for a maximallyexposed individual who continuously breathed air at the fenceline while engaged in light physical activity 24 hours a day for an entire year. The dose estimates presented in this report are for the reference man, which assumes an average body size and breathing rate.

An exposure conversion factor, using the previously stated assumptions, was used to calculate the radiation exposure to the lung from radon and its daughters based on radon concentrations in the air. The exposure was converted to a lung dose by 
1995 Radon Dose Estimates at the Fenceline

\begin{tabular}{llll} 
& 1995 & 1994 & Comments \\
\hline Radon Concentration & $0.7 \mathrm{pCi} / \mathrm{L}$ & $0.8 \mathrm{pCi} / \mathrm{L}$ & Average fenceline concentration \\
\hline Estimated Dose & $504 \mathrm{mrem}$ & $576 \mathrm{mrem}$ & Individual engaged in light activity 24 hours \\
\hline Estimated Dose & $448 \mathrm{mrem}$ & $511 \mathrm{mrem}$ & $\begin{array}{l}\text { Individual engaged in light activity } 16 \text { hours } \\
\text { a day, 8 hours resting }\end{array}$
\end{tabular}

using the quality factor for internal alpha particles ${ }^{39}$ The lung dose was converted to an estimated dose equivalent (whole body dose) by using the weighting factor for the lung. ${ }^{40}$ (See Chapter Two for a discussion on weighting factors.)

Dose estimates for radon use varies with a range of possible values. The second dose estimate is presented to illustrate the effects of changing any one factor in the calculation of an estimated dose from radon. This estimate used a more realistic assumption that the hypothetical person continuously breathed air at the fenceline for 24 hours a day but spent eight hours resting and 16 hours engaged in light activity each day for the entire year. Changing this assumption resulted in a reduction of about $10 \%$ of the radon dose estimate. Therefore, the radon dose conversion factor can be as high as approximately $120 \%$ of the values reported if all parameters except the radon concentration are unspecified. Dose estimates obtained using these assumptions produce high (conservative) dose estimates. For example, in reality, no person spends 24 hours a day engaged in light activity at the site fenceline. Therefore, an actual dose received would be less than the 504 mrem dose estimated.

Changes being considered during the coming year should help to resolve some of the problems that have occurred during the past year. Program improvement is a continuous process. The next chapter discusses the procedures and practices at the Fernald site used to ensure that environmental monitoring data are accurate representations of the conditions at the site. 


\section{QUALITY ASSURANCE FOR THE ENVIRONMENTAL MONITORING PROGRAM}

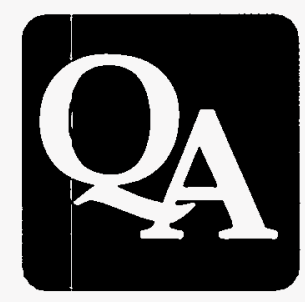





\section{Quality Assurance for the Environmental Monitoring Program}

Acquiring data of known quality is essential to environmental sampling and analysis. Because decisions are made and regulatory compliance is derived from environmental data, the Fernald site has developed comprehensive procedures that define how environmental sampling and analysis are to be conducted. These procedures generate consistency between programs and ensure environmental sampling and analysis using USEPA, DOE, or industry-accepted practices and standards. Quality Assurance (OA) provides the guidelines necessary to monitor the performance of these procedures in a controlled and consistent manner. Adherence to $Q A$ requirements generates confidence that environmental data are reliable. The $Q A$ process identifies the variability in data, establishes the OA objectives, and defines the level of confidence needed to meet the objectives. The accuracy and precision of sampling and field analysis are measured using traceable standard control samples.

\section{Results in Brief: 1995 Quality Assurance}

DOE's Environmental Measurements Laboratory (EML) Evaluation - Soil and air analyses of the DOE EML samples were shown to be within acceptable limits.

USEPA's Discharge Monitoring Report - All of the Fernald site analyses of USEPA wastewater samples were within acceptable limits.

Proficiency Environmental Testing (PET) - Of the 1,060 PET samples analyzed, $97 \%$ were within acceptable limits. 


\section{Sitewide CERCLA Quality Assurance Project Plan}

Environmental sampling and analysis activities mandated or supported by USEPA must contain a centrally managed QA program. Because the Fernald site generates data under CERCLA, it is required to implement procedures that ensure precision, accuracy, completeness, and representativeness of the entire program.

Collection and analysis of environmental samples are integral parts of fulfilling the site's mission and complying with environmental regulations. A single sample of a specific item from a specific location may provide information for a number of remedial investigation, restoration, waste management, and regulatory uses. Therefore, it is necessary that all environmental sampling and analysis be conducted in a consistent manner. This will result in usable, valid data of known quality so that use across programs is possible and the level of uncertainty associated with such data is known.

The Sitewide CERCLA Quality Assurance Project Plan (SCQ) was developed and implemented in 1994 for environmental sampling and analysis activities. It establishes minimum standards of performance for operational and analytical activities, while ensuring that these standards are followed by all programs.

\section{Data Quality Objectives}

Prior to sample collection, the Data Quality Objective (DQO) process begins. The DQO process provides a means for the decision maker and the technical team to define the level of quality needed in the data to support a decision. The regulatory requirements are identified and the sampling and analysis plans are designed before the samples are generated. When the sampling and analysis plans are designed, the variables established through the DQO process are used to determine the number of samples needed, including QA samples, and to ensure the total level of uncertainty from sampling and analysis is acceptable.

\section{Quality Assurance: Field Activities}

Quality assurance on field activities is an important part of the environmental monitoring process. The site's environmental monitoring procedures contain detailed QA measures for meeting the criteria established in the DQOs. Only trained personnel who have demonstrated proficiency in making field measurements and collecting representative samples are permitted to perform these functions. Examples of field activities follow.

\section{Field Analysis}

Field measurements offer benefits in time and cost because they provide immediate results on environmental conditions, ensuring that the site maintains compliance with certain parameters. Measurements are made with instruments calibrated 
against known standards and accepted methods. Instrument QA includes routine performance checks, maintenance, and calibration to help ensure proper operation and accurate field measurements.

\section{Field Documentation}

Technicians must accurately and systematically record results of field measurements and information pertinent to sample collection for subsequent evaluation and reference. Procedures direct the environmental sampling process from before sample collection begins to sample delivery to the laboratory. Technicians record events and observations such as weather, location, time of sampling, and any unusual events that may influence the sample in field logbooks. Signing and dating all documents helps ensure the traceability and accountability of field activities sampling.

\section{Field QA/Representative Sampling}

Environmental samples that field technicians collect must be representative of actual conditions in the environment. As such, the site designs sampling programs to reduce sample degradation, sampling variability, and cross-contamination.

Fernald personnel take precautions to prevent changing of sample constituents by purchasing certified clean sample containers and using sample preservatives when needed. Such precautions are necessary to prevent changes that can occur in some samples due to biodegradation from microorganisms, the loss of volatile compounds with increasing temperature, or the loss of trace metals from solution by adsorption onto sample container walls. Refrigeration, or icing, and the addition of chemical preservatives (such as nitric or sulfuric acid) are used to decrease volatility of organic compounds, control biological and chemical changes, and maintain trace metals in solution.

The use of standardized procedures reduces sampling variability. These procedures ensure consistency from one collection to another. Sampling variability is measured by taking duplicate samples of the same type. The precision of the site's sample collection and laboratory reproducibility is demonstrated when the analysis results for the duplicate samples are within acceptable limits.

When conducting duplicate sampling, a technician collects two samples from the same location. The samples are then submitted to the same laboratory or submitted to separate laboratories as a means of assessing the precision of the analysis. If the results from both analyses are similar, then the precision is verified.

The quality of the sample collection process is also evaluated by means of field and equipment blanks. These sample blanks provide valuable data and provide a means of monitoring the sampling process for cross-contamination. The blanks are transported along with the sample containers being taken by the sampling team into the field. When sampling is complete, the blanks are submitted along 
with the field samples for laboratory analyses. A brief description of different types of blanks follows.

Trip blanks are prepared by filling sample containers with de-ionized water. Anything that will be added to the samples to preserve them after collection is also added to the blanks. The containers are then sealed with tamper-proof tape and transported to the sampling location along with the empty sample containers. Trip blank analyses are used to determine whether conditions encountered during sample container shipment and handling have affected sample quality.

Field blanks are prepared in the laboratory or in the field by filling sample containers with de-ionized water. Unlike trip blanks, field blanks are not sealed until after all samples have been collected. The container is opened and exposed to the air while other samples are being collected. Results from the field blanks determine if airborne contamination may have entered the field samples during the collection process.

Equipment rinsate blanks consist of a composite of de-ionized water that has been used for a final rinse in cleaning sampling equipment. Results of equipment rinsate blanks are used to evaluate whether or not sampling equipment was free of contamination before being used to collect additional samples.

\section{Sample Custody}

Most environmental samples must be managed according to USEPA protocols. One such protocol is referred to as chain-of-custody. The custody procedure provides requirements for maintaining sample custody by approved personnel. A sample container and sample must be under custody at all times through final disposition.

All samples are obtained and documented according to the chain-of-custody procedure. This procedure requires personnel relinquishing and receiving custody of samples to sign, date, and note the time on a chain-of-custody record. This practice is done so that the sample integrity is maintained and all data are legally defensible.

\section{Analytical Laboratory Quality Assurance}

The Fernald site uses a variety of procedures to ensure the laboratories analyzing its samples obtain reliable results. These procedures typically begin with the receipt of samples from the field technicians. Laboratory QA is designed to:

- Ensure use of appropriate measuring equipment;

- Ensure use of approved analytical methods;

- Evaluate analytical performance systematically and objectively;

- Detect and prevent the use of questionable data; and

- Identify appropriate corrective actions. 


\section{Analytical Methods}

Many of the analytical methods used at the Fernald site are stipulated by federal laws and regulations. From time to time, modifications to these methods are needed to adjust for matrix effects or other interferences. In addition, other methods, primarily those used in radiological analyses, have not been established as standard USEPA methods. As part of QA, periodic review of the procedures verifies that the appropriate procedures are being used and procedure changes have been approved.

\section{Analytical Performance}

QA sample analyses provide day-to-day evaluation of the performance of the site laboratory as well as the contract laboratories. This evaluation is conducted by laboratories analyzing National Institute of Standards and Technology reference materials, USEPA radionuclide solutions, standardized reference solutions, spiked samples (samples to which known amounts of contaminants have been added), blank samples, and external proficiency samples. In addition, the site prepares duplicate samples and submits them to the laboratories conducting the analyses. At least $10 \%$ of the total number of samples analyzed are QA samples that are analyzed along with the field samples.

Fernald personnel evaluate the QA sample results and regularly submit reports to the laboratories to identify potential areas of concern. In addition to analyzing QA samples, all laboratories perform daily instrument calibrations, stability checks, and reagent checks to monitor for laboratory interference.

Analytical performance is also monitored through sample and matrix spikes. Using these spikes, laboratories determine the percent recoveries of known amounts of analytes that were added to the samples. In addition, matrix interferences can be identified and the accuracy of the analytical procedures can be established.

\section{Detection of Data Problems and Corrective Action}

As part of the QA program, internal and external groups perform surveillances on laboratory operations. Successful completion of on-the-job training and test sample performances are required for all new analysts, and routine performance checks assess their ability to correctly perform the analytical procedures. The accuracy of the analytical method is measured by the results of QA samples. If a problem is indicated, the laboratory is notified so that corrective actions can be taken and suspect results can be evaluated and qualified. Deviations are documented as a means of managing variations that occur in the analytical and data generation process. These reports are issued to the responsible manager and can be used as a means to track improvements in the quality system. 


\section{Independent Evaluations of the Fernald Site Laboratories}

In addition to the comprehensive internal QA program, onsite laboratories regularly take part in several QA programs conducted by independent organizations. Participation in these external QA programs provides unbiased evaluations of the onsite laboratory performance and generates added confidence that results obtained for environmental samples are reliable.

External QA evaluations are conducted in the following manner. The organization conducting the evaluation prepares QA samples to which known amounts of a chemical or radioactive component are added. The samples, but not the known values of the test components, are distributed to the participating laboratories that analyze the samples and return the results. The organization administering the program then provides a performance evaluation report comparing the laboratories' results to the true values of the test components. In most cases, the report compares the results obtained by the other participating laboratories. These comparisons show whether the laboratories' analyses are within acceptable limits of accuracy or if improvements are required. Three of these programs are described below.

\section{DOE's Environmental Measurements Laboratory}

The Environmental Measurements Laboratory (EML) Program evaluates the performance of laboratories carrying out radionuclide analyses on environmental samples. Routinely, the Fernald site receives and analyzes air filters, soil, and water samples for uranium and submits the results for comparison with other laboratories in the program. In making the comparison, DOE computes a ratio by dividing the site's result by the EML result for each analyte. The ratio equals 1.00 when the results agree exactly. Results within $50 \%$ (ratios greater than 0.50 and less than 1.5) are considered acceptable.

The ratios for samples analyzed for uranium during 1995 are listed in Table 26 on page A-46. The results for the 1995 soil samples were within acceptable limits since the ratios of results ranged from 0.86 to 3.05 . The 1995 air filter sample ratio was 1.02 , which is acceptable. The water sample ratio was 1.12 . The Fernald site has established requirements for all of its contract laboratories to participate in the EML program and their results must be within 50\% of the EML results.

\section{USEPA's Discharge Monitoring Report}

USEPA requires all laboratories that perform NPDES permit wastewater analyses to participate in the Discharge Monitoring Report (DMR) QA program. The DMR QA evaluations of the Fernald site laboratories' performance began in 1985. This program evaluates the ability of laboratories to measure nonradioactive contami- 
nants in wastewater. As directed by USEPA, a corresponding QA sample must be analyzed for each parameter listed in the NPDES permit. The NPDES permit parameters measured by the Fernald site laboratories are discussed in Chapter Five under "Monitoring for Nonradioactive Pollutants." USEPA evaluates the results for the QA samples as acceptable or unacceptable.

Results obtained by Fernald site laboratories for the 1995 DMR QA samples are summarized in Table 27 on page A-47. All of the results submitted during 1995 for DMR QA were determined to be acceptable by USEPA.

\section{Commercial Proficiency Environmental Testing}

The Fernald site laboratories also participate in the Proficiency Environmental Testing (PET) QA program. This is a voluntary program administered by a commercial vendor of analytical laboratory QA services. Each laboratory pays a fee to participate. Periodically, the Fernald site submits PET samples to the various onsite laboratories concurrently with field samples. Results obtained from these QA samples are compiled and submitted for evaluation by the commercial vendor. A monthly evaluation report is then provided by the vendor comparing the results of the Fernald site to the reference values for each sample and to the results obtained by other laboratories participating in the PET program. By using this commercial service, the site has an additional resource for evaluating its laboratory performance.

A summary of the performance of the site laboratories in the PET QA program during 1995 is provided in Table 28 on pages A-48 and A-49. For the parameters reported, $97 \%$ of the results met acceptable criteria.

\section{Split Sampling Program}

Another enhancement to the Fernald site QA program is the split water, sediment, and milk program. The site has participated in this program with the state since 1987. In the split sample program, the true variability in analysis between laboratories is measured with the comparison of sample results that were collected directly from the environment.

This program is very similar to the duplicate sample program described above. Although the sampling is similar, the duplicate samples may measure a single laboratory's precision, whereas the split program measures comparability between two laboratories.

To obtain split samples, technicians alternately add a portion of the sample being collected to two individual sample containers. This collection method helps ensure that both samples are as identical as possible. Split samples are then submitted to two independent laboratories for analysis. The results for the 1995 OEPA split samples are presented in Tables 29 and 30 (pages A-50 through A-52). 
These tables show mixed agreement between Fernald and OEPA samples. The soil and groundwater split sample results are in good agreement. Sediment and grass sample results may differ by more than $50 \%$. The reasons for the poor agreement in sediment and grass samples results are not fully understood. The differences in sample handling and analysis procedures and variations in the sample themselves (despite efforts to homogenize the sample prior to splitting) may contribute to the larger than expected differences in the sample results.

\section{Contract Laboratory Quality Assurance}

Because of the great number of analyses required to support all its various environmental sampling and analyses programs, the Fernald site uses commercial laboratories to supplement its onsite analytical laboratories. Commercial laboratories must meet stringent requirements before being selected to provide environmental analytical services. Commercial laboratories, in many cases, must also be certified and have licenses from the state. To select the best qualified laboratory, experienced auditors conduct comprehensive reviews of the laboratory's management, operations, and performance. These reviews are conducted before and during the service life of the contract. Topics typically reviewed during the audits are:

- Analytical equipment;

- Analytical procedures;

- Personnel qualifications;

- Sample handling and preservation;

- Data evaluation and record keeping; and

- Requirements for precision, accuracy, and detection levels.

Auditors also review results obtained in independent QA programs as part of the evaluation of each candidate laboratory's analytical capabilities. Onsite audits of the laboratories' facilities and operations are then conducted by Sampling and Analysis Management, Procurement, and QA personnel before final selections are made. After selecting the laboratories, QA samples are submitted regularly with field samples in order to evaluate the contract laboratories performance on a continuing basis.

The Fernald site employed QA measures to evaluate the contract laboratory's analysis of uranium in milk samples. Spiked sample recoveries measure the accuracy of the analyses. Table 8 on page A-12 shows the percent recovery for the milk QA spike samples sent to the contract laboratory used for 1995 milk samples. Spiked sample results for January and February ranged from $102 \%$ to $109 \%$. Both recoveries were within the acceptable range of $50 \%$ to $150 \%$. 
APPENDICES 



\section{Fernald Site Environmental Monitoring Data for 1995}

Numerous sampling and analysis data are required to evaluate compliance with environmental regulations and to obtain accurate indications of the Fernald site's operations during 1995 . The sampling and analysis results are provided in summary tables.

Many of the numerical values listed in the following data tables are preceded by the "less than" symbol (<). The less than symbol is used when the concentration of a chemical species (ion, molecule, compound, or radionuclide) in an environmental media (air, water, or sediment) could not be reliably measured in the sample that was analyzed. That is, the amount of the species, if present at all in the sample, was below the minimum measurable concentration. Thus, a value of $<0.68 \mathrm{pCi} / \mathrm{L}$ listed as the concentration of uranium in milk means that the uranium concentration was less than $0.68 \mathrm{pCi} / \mathrm{L}$ but actually could have been anywhere from 0.00 to $0.67 \mathrm{pCi} / \mathrm{L}$.

The minimum measurable concentration is not the same for all chemical species. For example, $0.25 \mathrm{pCi} / \mathrm{g}$ of radium -226 and $0.21 \mathrm{pCi} / \mathrm{g}$ of plutonium-238 are the approximate minimum measurable concentrations for sediment samples. In addition to differences in the capabilities of instruments available to measure these properties, these variations exist because of differences in chemical and physical properties of species.

Also, the minimum measurable concentration is not always the same for a specific species in all samples of the same environmental media. That is, the minimum measurable concentration for uranium in groundwater samples may vary for water samples from two different locations. This is so because variations in the kinds or amounts of other substances in the two samples can influence how well a substance can be measured.

In addition, the minimum measurable concentration of a species will not always be the same for identical samples from the same location that are analyzed at different times. This variance occurs because of unavoidable minor fluctuations in the performance of analytical instrumentation used to perform sample measurements. 
TABLE 1: Meteorological Data, 1995

\begin{tabular}{|c|c|c|c|c|c|c|c|c|c|c|c|c|c|}
\hline & Units & January & February & March & April & May & June & July & August & September & October & November & December \\
\hline \multicolumn{14}{|c|}{ 10-Meter Wind Speed $(a)$} \\
\hline $\begin{array}{l}\text { Maximum } \\
\text { hourly average }\end{array}$ & $\mathrm{kph}$ & 37.5 & 39.4 & 45.5 & 43.9 & 46.7 & 30.1 & 46.4 & 26.2 & 25.1 & 41.5 & 48.0 & 36.2 \\
\hline $\begin{array}{l}\text { Minimum } \\
\text { hourly average }\end{array}$ & $\mathrm{kph}$ & 1.6 & 1.1 & 0.3 & 1.5 & 1.5 & 1.8 & 1.0 & 0.5 & 1.0 & 0.6 & 1.5 & 1.6 \\
\hline \multicolumn{14}{|c|}{ 60-Meter Wind Speed (a) } \\
\hline $\begin{array}{l}\text { Maximum } \\
\text { hourly average }\end{array}$ & $\mathrm{kph}$ & 13.4 & 16.8 & 16.4 & 17.5 & 15.8 & 10.9 & 15.4 & 11.0 & 11.1 & 17.5 & $\overline{16.6}$ & 14.2 \\
\hline $\begin{array}{l}\text { Minimum } \\
\text { hourly average }\end{array}$ & $\mathrm{kph}$ & 0.6 & 0.7 & 0.4 & 0.7 & 0.2 & 0.2 & 0.2 & 0.5 & 0.7 & 0.5 & 0.6 & 0.5 \\
\hline \multicolumn{14}{|c|}{ Ambient Air Temperature ${ }^{(b)}$} \\
\hline Average & ${ }^{\circ} \mathrm{C}$ & -1.2 & -1.9 & 6.4 & 10.9 & 15.6 & 20.8 & 22.9 & 23.6 & 16.2 & 11.9 & 3.4 & -1.6 \\
\hline Maximum & ${ }^{\circ} \mathrm{C}$ & 19.4 & 17.9 & 23.8 & 26.1 & 26.7 & 32.2 & 35.4 & 33.7 & 30.2 & 26.5 & 20.9 & 18.7 \\
\hline Minimum & ${ }^{\circ} \mathrm{C}$ & -18.4 & -23.6 & -6.9 & -7.4 & -0.6 & 7.2 & 7.3 & 8.4 & -2.6 & -2.6 & -9.4 & -16.4 \\
\hline \multicolumn{14}{|l|}{ Precipitation (c) } \\
\hline Monthly Total & $\mathrm{cm}$ & 7.95 & 3.86 & 6.30 & 12.55 & 25.88 & 5.84 & 7.72 & 14.22 & 5.89 & 11.43 & 5.33 & 7.85 \\
\hline Daily Maximum & $\mathrm{cm}$ & 1.78 & 1.91 & 2.51 & 3.78 & 8.46 & 1.75 & 2.06 & 7.80 & 3.25 & 6.25 & 2.49 & 2.51 \\
\hline
\end{tabular}

(a) To obtain wind speeds in miles per hour, divide by 1.6093.

(b) Ambient air temperature is measured at the 10-meter (33-foot) level. To obtain ${ }^{\circ} \mathrm{F}$, multiply ${ }^{\circ} \mathrm{C}$ by 9 , divide by 5 , and add 32 .

(c) To obtain precipitation amounts in inches, divide by 2.54 . 
TABLE 2: Estimated Population Distribution within

$80 \mathrm{~km}$ (50 miles) of the Fernald Site, 1995(a)

\begin{tabular}{|c|c|c|c|c|c|c|c|c|c|c|}
\hline $\begin{array}{c}\text { Compass } \\
\text { Sector }\end{array}$ & $\begin{array}{c}0-1.6 \mathrm{~km} \\
(0-1 \text { mile }) \\
\end{array}$ & $\begin{array}{r}1.6-3.2 \mathrm{~km} \\
(1-2 \text { miles })\end{array}$ & $\begin{array}{l}3.2-4.8 \mathrm{~km} \\
(2-3 \text { miles })\end{array}$ & \begin{tabular}{|l|}
$4.8-6.4 \mathrm{~km}$ \\
$(3-4$ miles) \\
\end{tabular} & $\begin{array}{c}6.4-8 \mathrm{~km} \\
(4-5 \text { miles })\end{array}$ & $\begin{array}{c}8-16 \mathrm{~km} \\
(5-10 \text { miles })\end{array}$ & $\begin{array}{c}16-32 \mathrm{~km} \\
(10-20 \text { miles })\end{array}$ & $\begin{array}{c}32-48 \mathrm{~km} \\
(20-30 \text { miles })\end{array}$ & $\begin{array}{c}48-64 \mathrm{~km} \\
(30-40 \text { miles })\end{array}$ & $\begin{array}{c}64-80 \mathrm{~km} \\
(40-50 \text { miles })\end{array}$ \\
\hline$N$ & 2 & 54 & 193 & 20 & 140 & 2,157 & 15,117 & 7,201 & 16,590 & 13,291 \\
\hline NNE & 0 & 71 & 51 & 113 & 147 & 12,263 & 8,174 & 9,742 & 30,568 & 86,398 \\
\hline NE & 2 & 202 & 827 & 97 & 90 & 34,292 & 38,797 & 88,477 & 214,495 & 331,340 \\
\hline ENE & 5 & 87 & 1,766 & 219 & 13 & 31,999 & 32,998 & 32,039 & 14,739 & 29,771 \\
\hline$E$ & 3 & 3 & 179 & 301 & 248 & 38,285 & 75,213 & 50,799 & 17,863 & 10,218 \\
\hline ESE & 8 & 54 & 78 & 558 & 739 & 42,893 & 160,628 & 68,672 & 22,433 & 13,541 \\
\hline SE & 10 & 200 & 52 & 394 & 680 & 53,789 & 271,217 & 96,398 & 28,351 & 11,194 \\
\hline SSE & 6 & 349 & 165 & 217 & 492 & 21,506 & 226,652 & 58,844 & 12,567 & 8,122 \\
\hline$S$ & 3 & 7 & 17 & 253 & 538 & 9,177 & 32,980 & 38,030 & 8,392 & 9,825 \\
\hline SSW & 3 & 27 & 205 & 40 & 188 & 5,638 & 8,999 & 7,630 & 5,390 & 10,277 \\
\hline SW & 2 & 37 & 26 & 355 & 60 & 4,486 & 14,209 & 9,197 & 3,523 & 4,341 \\
\hline WSW & 0 & 15 & 40 & 511 & 313 & 8,540 & 5,255 & 7,725 & 7,556 & 4,681 \\
\hline$W$ & 6 & 13 & 37 & 286 & 596 & 1,664 & 3,547 & 10,295 & 5,357 & 15,708 \\
\hline WNW & 5 & 20 & 60 & 123 & 121 & 1,093 & 4,675 & 4,205 & 5,714 & 11,295 \\
\hline NW & 1 & 18 & 261 & 269 & 254 & 1,196 & 1,423 & 3,757 & 22,376 & 8,795 \\
\hline NNW & 2 & 7 & 97 & 312 & 722 & 1,239 & 12,713 & 5,128 & 48,409 & 15,256 \\
\hline Total & 58 & 1,164 & 4,054 & 4,068 & 5,341 & 270,217 & 912,597 & 498,139 & 464,323 & 584,053 \\
\hline
\end{tabular}

(a) Based on an extrapolation from 1990 census data by Geographic Data Systems Section,

Computing and Telecommunications Division at Oak Ridge National Laboratory, April 1992. 


\begin{tabular}{|c|c|c|c|c|c|}
\hline $\begin{array}{c}\text { Sampling } \\
\text { Location }\end{array}$ & $\begin{array}{c}\text { Number } \\
\text { of Samples }\end{array}$ & $\begin{array}{c}\text { Concentration } \\
\text { Maximum }\end{array}$ & $\begin{array}{l}\left.3 \times 10^{-6}\right)^{(b)} \\
\text { lerage }\end{array}$ & $\begin{array}{l}\text { Percent of } \\
\text { Maximum }\end{array}$ & $\begin{array}{l}\text { dard }(c) \\
\text { Average }\end{array}$ \\
\hline \multicolumn{6}{|l|}{ Fenceline } \\
\hline AMS 2 & 26 & 190 & 83 & 0.19 & 0.083 \\
\hline AMS 3 & 26 & 400 & 170 & 0.4 & 0.17 \\
\hline AMS 4 & 26 & 180 & 84 & 0.18 & 0.084 \\
\hline AMS 5 & 26 & 150 & 59 & 0.15 & 0.059 \\
\hline AMS 6 & 26 & 230 & 60 & 0.23 & 0.06 \\
\hline AMS 7 & 26 & 130 & 39 & 0.13 & 0.039 \\
\hline
\end{tabular}

\section{Onsite}

\begin{tabular}{|c|c|c|c|c|c|}
\hline AMS 1A & 25 & 450 & 190 & 0.45 & 0.19 \\
\hline AMS 8 & 26 & 430 & 190 & 0.43 & 0.19 \\
\hline AMS 9A & 26 & 980 & 250 & 0.98 & 0.25 \\
\hline
\end{tabular}

\section{Waste Pits Area}

\begin{tabular}{|l|l|l|l|l|l|}
\hline AMS 17 & 26 & 300 & 92 & 0.30 & 0.092 \\
\hline AMS 18 & 26 & 970 & 320 & 0.97 & 0.32 \\
\hline AMS 19 & 26 & 180 & 53 & 0.18 & 0.053 \\
\hline AMS 20 & 26 & 200 & 58 & 0.20 & 0.058 \\
\hline
\end{tabular}

\section{Offsite}

\begin{tabular}{|l|l|l|l|l|l|}
\hline AMS 10 & 26 & 89 & 36 & 0.089 & 0.036 \\
\hline AMS 11 & 26 & 140 & 41 & 0.14 & 0.041 \\
\hline AMS 12 & 26 & 110 & 34 & 0.11 & 0.034 \\
\hline AMS 13 & 26 & 94 & 35 & 0.094 & 0.035 \\
\hline AMS 14 & 26 & 78 & 33 & 0.078 & 0.033 \\
\hline AMS 16 & 26 & 110 & 36 & 0.11 & 0.036 \\
\hline AMS 21 $(d)$ & 17 & 43 & 30 & 0.043 & 0.030 \\
\hline
\end{tabular}

(a) See Figure 22 on page 82 for locations.

(b) The amount of uranium in each sample is chemically determined and converted to units of activity using the conversion constant of $0.68 \mathrm{pCi} / \mu \mathrm{g}$ (natural uranium). Negative results indicate that the amount of uranium in the sample was less than the amount of uranium measured in a blank filter.

(c) Standard is $100,000 \times 10^{-6} \mathrm{pCi} / \mathrm{m}^{3}$, as listed in DOE Order 5400.5, "Radiation Protection of the Public and Environment."

(d) New background monitoring station added in May 1995. Replaces AMS 15. 


\begin{tabular}{|c|c|c|c|c|c|}
\hline \multicolumn{7}{|c|}{ Concentration $\left(\mathrm{pCi} / \mathrm{m}^{\mathbf{3}} \times \mathbf{1 0}\right.$-6) (a) } \\
\hline $\begin{array}{c}\text { Sampling } \\
\text { Location }\end{array}$ & Strontium-90 & Technetium-99 & Cesium-137 & Radium-226 & Radium-228 \\
\hline AMS 1A & $<5.5$ & $<97.4$ & $<23.3$ & $<1.4$ & $<17.3$ \\
\hline AMS 2 & $<5.3$ & $<84.2$ & $<22.2$ & $<1.5$ & $<14.7$ \\
\hline AMS 3 & $<6.1$ & $<99.3$ & $<24.2$ & $<2.4$ & $23.9 \pm 15.9$ \\
\hline AMS 4 & $<5.8$ & $867.0 \pm 53.8$ & $<23.3$ & $<2.0$ & $<11.9$ \\
\hline AMS 5 & $<5.1$ & $<85.7$ & $23.8 \pm 27.8$ & $<1.4$ & $<13.2$ \\
\hline AMS 6 & $<5.4$ & $<84.7$ & $<21.4$ & $<2.2$ & $<11.6$ \\
\hline AMS 7 & $<5.5$ & $<96.2$ & $<10.5$ & $<1.4$ & $<14.7$ \\
\hline AMS 8 & $<5.2$ & $<85.9$ & $<16.6$ & $<1.3$ & $<13.2$ \\
\hline AMS 9A & $14.1 \pm 4.4$ & $292.0 \pm 40.7$ & $<20.4$ & $<10.3$ & $<11.2$ \\
\hline AMS 10 & $<2.0$ & $<100.0$ & $<20.0$ & $3.0 \pm 0.7$ & $3.0 \pm 2.0$ \\
\hline AMS 11 & $<20.0$ & $<70.0$ & $<20.0$ & $2.0 \pm 0.7$ & $<3.0$ \\
\hline AMS 12 & $<2.0$ & $<100.0$ & $<10.0$ & $2.0 \pm 0.6$ & $<4.0$ \\
\hline AMS 13 & $<2.0$ & $<100.0$ & $<20.0$ & $2.0 \pm 0.6$ & $3.0 \pm 2.0$ \\
\hline AMS 14 & $<2.0$ & $<100.0$ & $<20.0$ & $3.0 \pm 0.9$ & $<4.0$ \\
\hline AMS 16 & $2.0 \pm 1.0$ & $<70.0$ & $<20.0$ & $3.0 \pm 0.8$ & $<4.0$ \\
\hline AMS 17 & $<45.8$ & $<93.4$ & $<111.0$ & $<13.1$ & $<50.9$ \\
\hline AMS 18 & $<6.1$ & $<107.0$ & $<22.8$ & $<2.2$ & $22.3 \pm 12.6$ \\
\hline AMS 19 & $107.0 \pm 6.8$ & $<100.0$ & $<23.1$ & $<2.0$ & $17.1 \pm 14.7$ \\
\hline AMS 20 & $<6.6$ & N/A & $21.3 \pm 28.5$ & $<3.5$ & $<17.4$ \\
\hline AMS 21 & $<3.0$ & $<100.0$ & $<30.0$ & $3.0 \pm 1.0$ & $<7.0$ \\
\hline DCG(c) & $9,000,000$ & $2,000,000,000$ & $400,000,000$ & $1,000,000$ & $3,000,000$ \\
\hline & & & & & \\
\hline
\end{tabular}




\begin{tabular}{|c|c|c|c|c|c|}
\hline \multicolumn{7}{|c|}{ Concentration $\left(\mathrm{pCi} / \mathrm{m}^{3} \times 10^{-6}\right)(\mathrm{a})$} \\
\hline $\begin{array}{c}\text { Sampling } \\
\text { Location }(\mathrm{b})\end{array}$ & Thorium-228 & Thorium-230 & Thorium-232 & Uranium-234 & Uranium-235/236 \\
\hline AMS 1A & $2.3 \pm 2.0$ & $7.5 \pm 3.0$ & $4.6 \pm 1.6$ & $40.8 \pm 4.9$ & $24.8 \pm 2.8$ \\
\hline AMS 2 & $<1.1$ & $<2.4$ & $<0.5$ & $16.4 \pm 4.7$ & $10.0 \pm 2.5$ \\
\hline AMS 3 & $<1.3$ & $4.8+3.1$ & $<0.6$ & $33.9 \pm 43.3$ & $40.7 \pm 23.7$ \\
\hline AMS 4 & $<1.2$ & $<2.5$ & $<0.6$ & $<2.4$ & $5.3 \pm 2.1$ \\
\hline AMS 5 & $2.8 \pm 1.3$ & $3.6 \pm 2.6$ & $1.6 \pm 1.3$ & $<2.3$ & $<0.6$ \\
\hline AMS 6 & $3.2 \pm 1.7$ & $3.6 \pm 2.4$ & $1.1 \pm 1.2$ & $13.0 \pm 4.2$ & $<0.6$ \\
\hline AMS 7 & $2.5 \pm 2.0$ & $<2.5$ & $<0.7$ & $<2.3$ & $4.9 \pm 2.1$ \\
\hline AMS 8 & $<1.1$ & $4.2 \pm 2.6$ & $2.2 \pm 1.4$ & $62.4 \pm 4.6$ & $6.9 \pm 2.1$ \\
\hline AMS 9A & $<1.1$ & $3.0 \pm 2.6$ & $<0.6$ & $46.9 \pm 5.2$ & $13.4 \pm 2.7$ \\
\hline AMS 10 & $<2.0$ & $<6.0$ & $<1.0$ & $2.0 \pm 2.0$ & $<0.9$ \\
\hline AMS 11 & $<2.0$ & $<7.0$ & $<2.0$ & $2.0 \pm 2.0$ & $<0.9$ \\
\hline AMS 12 & $<2.0$ & $<6.0$ & $<1.0$ & $2.0 \pm 2.0$ & $<1.0$ \\
\hline AMS 13 & $<2.0$ & $<6.0$ & $<1.0$ & $3.0 \pm 2.0$ & $1.0 \pm 0.9$ \\
\hline AMS 14 & $<2.0$ & $<7.0$ & $<1.0$ & $3.0 \pm 2.0$ & $<1.0$ \\
\hline AMS 16 & $<2.0$ & $<6.0$ & $<1.0$ & $4.0 \pm 2.0$ & $1.0 \pm 0.9$ \\
\hline AMS 17 & $<3.4$ & $16.2 \pm 5.6$ & $3.0 \pm 2.1$ & $<4.8$ & $<2.9$ \\
\hline AMS 18 & $2.7 \pm 2.1$ & $3.5 \pm 2.8$ & $<0.5$ & $<1.3$ & $<0.8$ \\
\hline AMS 19 & $<1.0$ & $<2.1$ & $<0.5$ & $<1.3$ & $<0.8$ \\
\hline AMS 20 & $<1.0$ & $<2.2$ & $<0.5$ & $10.1 \pm 4.5$ & $5.9 \pm 2.4$ \\
\hline AMS 21 & $<3.0$ & $<10.0$ & $<2.0$ & $<4.0$ & $<2.0$ \\
\hline DCG (c) & 40,000 & 40,000 & 7,000 & 90,000 & 100,000 \\
\hline & & & & & \\
\hline
\end{tabular}




\begin{tabular}{|c|c|c|c|}
\hline \multicolumn{4}{|c|}{ Concentration $\left(\mathrm{pCi} / \mathrm{m}^{3} \times 10^{-6}\right)(\mathrm{a})$} \\
\hline $\begin{array}{l}\text { Sampling } \\
\text { Location (b) }\end{array}$ & Uranium-238 & Plutonium-238 & Plutonium-239/240 \\
\hline AMS $1 \mathrm{~A}$ & $49.6 \pm 4.8$ & $<0.4$ & $<0.3$ \\
\hline AMS 2 & $20.9 \pm 4.5$ & $<0.5$ & $<0.3$ \\
\hline AMS 3 & $53.3 \pm 57.4$ & $<1.0$ & $<0.4$ \\
\hline AMS 4 & $1.4 \pm 3.8$ & $<0.4$ & $<0.2$ \\
\hline AMS 5 & $<0.5$ & $<0.4$ & $<0.3$ \\
\hline AMS 6 & $10.2 \pm 3.9$ & $<0.5$ & $<0.2$ \\
\hline AMS 7 & $<0.5$ & $<0.5$ & $<0.3$ \\
\hline AMS 8 & $60.5 \pm 4.4$ & $<0.4$ & $<0.3$ \\
\hline AMS 9A & $45.7 \pm 5.0$ & $<0.7$ & $<0.6$ \\
\hline AMS 10 & $2.0 \pm 1.0$ & $\mathrm{~N} / \mathrm{A}$ & $\mathrm{N} / \mathrm{A}$ \\
\hline AMS 11 & $2.0 \pm 1.0$ & N/A & $\mathrm{N} / \mathrm{A}$ \\
\hline AMS 12 & $2.0 \pm 1.0$ & N/A & $\mathrm{N} / \mathrm{A}$ \\
\hline AMS 13 & $3.0 \pm 2.0$ & N/A & $N / A$ \\
\hline AMS 14 & $2.0 \pm 1.0$ & $\mathrm{~N} / \mathrm{A}$ & $\mathrm{N} / \mathrm{A}$ \\
\hline AMS 16 & $3.0 \pm 2.0$ & N/A & $\mathrm{N} / \mathrm{A}$ \\
\hline AMS 17 & $<2.8$ & $<1.9$ & $2.3 \pm 1.1$ \\
\hline AMS 18 & $37.9 \pm 4.6$ & $<0.6$ & $<0.4$ \\
\hline AMS 19 & $<0.8$ & $<0.6$ & $<0.4$ \\
\hline AMS 20 & $6.8 \pm 4.4$ & $<0.6$ & $<0.3$ \\
\hline AMS 21 & $4.0 \pm 2.0$ & $\mathrm{~N} / \mathrm{A}$ & $N / A$ \\
\hline$D_{C G}(\mathrm{c})$ & 100,000 & 30,000 & 20,000 \\
\hline
\end{tabular}

(a) Plus/minus ( \pm ) values are the uncertainty in the analytical results at the $95 \%$ confidence level.

(b) See Figure 22 on page 82 for sampling locations.

(c) Derived concentration guides from DOE Order 5400.5, "Radiation Protection of the Public Environment," February 1990. Continuous inhalation of this concentration will result in a committed effective dose equivalent of $100 \mathrm{mrem}$ ( $1 \mathrm{mSv}$ ).

N/A Data not available. 
Table 5: Plant 4 Monitoring Results, 1995

\section{Uranium in Air}

\begin{tabular}{|c|c|c|c|c|}
\hline \multirow{2}{*}{$\begin{array}{l}\text { Sampling } \\
\text { Location(a) }\end{array}$} & \multirow{2}{*}{$\begin{array}{l}\text { Number } \\
\text { of Samples }\end{array}$} & \multirow{2}{*}{$\begin{array}{l}\text { Concentration } \\
\left(\mathrm{pCi} / \mathrm{m}^{3} \times 10^{-6}\right)\end{array}$} & \multicolumn{2}{|c|}{ Percent of Standard $(\mathrm{b})$} \\
\hline & & & Maximum & Average \\
\hline P4-1 & 40 & 1120 & 2.94 & 1.12 \\
\hline $\mathrm{P} 4-2$ & 40 & 2510 & 8.38 & 2.51 \\
\hline $\mathrm{P} 4-3$ & 38 & 1870 & 4.6 & 1.87 \\
\hline $\mathrm{P} 4-4$ & 40 & 2980 & 9.44 & 2.98 \\
\hline P4-5 & 36 & 8610 & 22.7 & 8.61 \\
\hline P4-6 & 39 & 2190 & 10.10 & 2.19 \\
\hline $\mathrm{P} 4-7$ & 40 & 2680 & 9.11 & 2.68 \\
\hline
\end{tabular}

(a) See Figure 26 on page 88 for sampling locations.

(b) The amount of uranium in each sample is chemically determined and converted to units of activity using the conversion constant of $0.68 \mathrm{pCi} / \mathrm{ug}$ (natural uranium). 


\begin{tabular}{|c|c|c|c|c|c|c|}
\hline $\begin{array}{l}\text { Sampling } \\
\text { Location(a) }\end{array}$ & $\begin{array}{l}\text { Distance from } \\
\text { Center of } \\
\text { the Site }(\mathrm{km})\end{array}$ & $\begin{array}{r}\text { Uranium } \\
\text { (pCi/g }\end{array}$ & $\begin{array}{l}\text { irass } \\
\text { Concentration } \\
\text { g dry) (b) }\end{array}$ & $\begin{array}{r}\text { Uranium } \\
\text { (pCi }\end{array}$ & & :entration \\
\hline \multicolumn{7}{|l|}{ Onsite } \\
\hline $1 \mathrm{~A}$ & 0.1 & 0.049 & \pm 0.0026 & 33 & \pm & 2.2 \\
\hline 9 & 0.1 & 0.068 & $\pm \quad 0.0026$ & 34 & \pm & 2.3 \\
\hline 8 & 0.15 & 0.60 & $\pm \quad 0.017$ & 23 & \pm & 1.6 \\
\hline \multicolumn{7}{|l|}{ Fenceline } \\
\hline 3 & 0.16 & 0.026 & $\pm \quad 0.0018$ & 65 & \pm & 4.3 \\
\hline 4 & 0.49 & 0.036 & \pm 0.0018 & 3.4 & \pm & 0.10 \\
\hline 5 & 0.63 & 0.013 & \pm 0.0009 & 9.5 & \pm & 0.25 \\
\hline 6 & 0.64 & 0.056 & $\pm \quad 0.0022$ & 9.5 & \pm & 0.24 \\
\hline 2 & 1.1 & 0.095 & \pm 0.0063 & 7.4 & \pm & 0.2 \\
\hline 7 & 1.3 & 0.012 & $\pm \quad 0.0009$ & 3.5 & \pm & 0.10 \\
\hline \multicolumn{7}{|l|}{ Offsite } \\
\hline 15 & 1.9 & $<0.00088$ & & 2.2 & \pm & 0.06 \\
\hline 18 & 2.3 & 0.0024 & $\pm \quad 0.0007$ & 2.3 & \pm & 0.06 \\
\hline 24 & 2.4 & 0.021 & \pm 0.0020 & 6.0 & \pm & 0.16 \\
\hline 25 & 2.7 & 0.10 & $\pm \quad 0.0074$ & 4.7 & \pm & 0.12 \\
\hline 33 & 4.2 & 0.074 & $\pm \quad 0.0033$ & 2.2 & \pm & 0.06 \\
\hline 13 & 5.4 & 0.0074 & \pm 0.0011 & 2.0 & \pm & 0.05 \\
\hline 40 & 37 & 0.13 & \pm 0.011 & 1.4 & \pm & 0.04 \\
\hline
\end{tabular}

(a) Locations (see Figure 27 on page 89 ) are listed in order of increasing distance from the center of the Fernald site production area (Plant 4).

(b) To obtain Bq/g, multiply pCi/g by 0.037 . The plus/minus ( \pm ) values are the uncertainty in the analytical results at the $95 \%$ confidence level. 
TABLE 7: Uranium in Produce and Soil, 1995

\begin{tabular}{|c|c|c|}
\hline $\begin{array}{c}\text { Sampling } \\
\text { Location }(\mathrm{a})\end{array}$ & $\begin{array}{c}\text { Distance } \\
\text { from Center } \\
\text { of the Site }(\mathbf{k m})\end{array}$ & $\begin{array}{l}\text { Concentration } \\
(\mathrm{pCi} / \mathrm{g} \text { dry })\end{array}$ \\
\hline
\end{tabular}

Soil

\begin{tabular}{|c|c|c|c|c|}
\hline $19 \mathrm{~K}-2$ & 1.4 & 3.8 & \pm & 0.12 \\
\hline $14 \mathrm{~K}-1$ & 1.6 & 3.9 & \pm & 0.12 \\
\hline 23 & 1.6 & 3.4 & \pm & 0.10 \\
\hline 23 & 1.6 & 2.4 & \pm & 0.09 \\
\hline $24 \mathrm{~K}-3$ & 1.6 & 3.2 & \pm & 0.09 \\
\hline 9 & 1.6 & 2.0 & \pm & 0.09 \\
\hline $18 \mathrm{~K}-4$ & 1.9 & 3.4 & \pm & 0.10 \\
\hline $18 \mathrm{~K}-5$ & 1.9 & 1.5 & \pm & 0.05 \\
\hline $18 \mathrm{~K}-6$ & 1.9 & 1.8 & \pm & 0.05 \\
\hline $18 \mathrm{~K}-7$ & 1.9 & 1.3 & \pm & 0.05 \\
\hline 4 & 1.9 & 2.2 & \pm & 0.09 \\
\hline 6 & 2.0 & 1.7 & \pm & 0.07 \\
\hline 20 & 2.1 & 3.4 & \pm & 0.10 \\
\hline 20 & 2.4 & 1.8 & \pm & 0.08 \\
\hline 21 & 2.4 & 2.1 & \pm & 0.09 \\
\hline 21 & 2.4 & 2.0 & \pm & 0.06 \\
\hline 5 & 2.9 & 2.0 & \pm & 0.08 \\
\hline 12 & 3.6 & 1.8 & \pm & 0.08 \\
\hline 13 & 3.8 & 1.4 & \pm & 0.07 \\
\hline 10 & 4.0 & 1.4 & \pm & 0.05 \\
\hline 7 & 4.9 & 1.2 & \pm & 0.09 \\
\hline 28 & 6.2 & 1.9 & \pm & 0.09 \\
\hline 17 & 16.0 & 1.4 & \pm & 0.06 \\
\hline 17 & 16.0 & 1.3 & \pm & 0.07 \\
\hline 16 & 30.0 & 1.3 & \pm & 0.07 \\
\hline 22 & 42.0 & 1.2 & \pm & 0.05 \\
\hline 34 & 42.0 & 1.4 & \pm & 0.06 \\
\hline
\end{tabular}

\begin{tabular}{|c|c|}
\hline $\begin{array}{c}\text { Sampling } \\
\text { Location }^{(a)}\end{array}$ & $\begin{array}{c}\text { Concentration } \\
\text { (pCi/g dry) }^{(b)}\end{array}$ \\
\hline
\end{tabular}

Tomatoes

\begin{tabular}{|c|l|}
\hline 9 & $<0.000039$ \\
\hline 4 & $0.000226 \pm 0.000048$ \\
\hline 5 & $0.000021 \pm$ \\
\hline 12 & $<0.000049$ \\
\hline 13 & $0.00057 \pm 000021$ \\
\hline 10 & $<0.000033$ \\
\hline 7 & $0.00064 \pm 000050$ \\
\hline 28 & $0.00030 \pm 0.00017$ \\
\hline 17 & $0.00018 \pm 00060$ \\
\hline 16 & $0.00048 \pm 0.000087$ \\
\hline 34 & $0.00034 \pm 000044$ \\
\hline
\end{tabular}

Green Peppers

\begin{tabular}{|c|l|}
\hline 10 & $<0.000044$ \\
\hline 4 & $0.00036 \pm 0.000028$ \\
\hline 34 & $0.00030 \pm 0.000026$ \\
\hline Potatoes \\
\hline 4 & $0.00022 \pm 0.000026$ \\
\hline 12 & $0.0060 \pm 0.00020$ \\
\hline 13 & $0.0034 \pm 0.00068$ \\
\hline
\end{tabular}

\section{Apples}

Apples
\begin{tabular}{|c|ll|}
\hline 6 & $<0.00085$ \\
\hline 12 & $0.00040 \pm$ & 0.00014 \\
\hline 13 & $0.00040 \pm$ & 0.000085 \\
\hline 10 & $0.00049 \pm$ & 0.000058 \\
\hline 17 & $0.000031 \pm$ & 0.0000064 \\
\hline
\end{tabular}

page 1 of 2

\begin{tabular}{|c|c|}
\hline $\begin{array}{c}\text { Sampling } \\
\text { Location }\end{array}$ & $\begin{array}{c}\text { Concentration } \\
\text { (pCi/g dry) }^{(b)}\end{array}$ \\
\hline
\end{tabular}

Corn
\begin{tabular}{|c|lll|}
\hline 24 & 0.0013 & \pm & 0.000037 \\
\hline 23 & 0.00013 & \pm & 0.000026 \\
\hline 18 & 0.00013 & \pm & 0.000022 \\
\hline 4 & 0.000037 & \pm & 0.0000073 \\
\hline 18 & $<0.000025$ & & \\
\hline 18 & 0.0018 & \pm & 0.0007 \\
\hline 6 & 0.00012 & \pm 0.0000078 \\
\hline 20 & 0.00027 & \pm & 0.000050 \\
\hline 21 & 0.00028 & \pm & 0.00011 \\
\hline 13 & 0.000092 & \pm & 0.000015 \\
\hline 10 & 0.00000015 & \pm 0.000000015 \\
\hline 10 & $<0.000048$ & \\
\hline 17 & 0.0011 & \pm 0.000044 \\
\hline 22 & 0.00022 & \pm 0.000051 \\
\hline
\end{tabular}

Green Beans

\begin{tabular}{|c|c|}
\hline 4 & $0.0013 \pm 0.000089$ \\
\hline 6 & $0.0042 \pm 0.00014$ \\
\hline 5 & $0.00029 \pm 0.000015$ \\
\hline 17 & $<0.000072$ \\
\hline 34 & $0.00025 \pm 0.000031$ \\
\hline
\end{tabular}




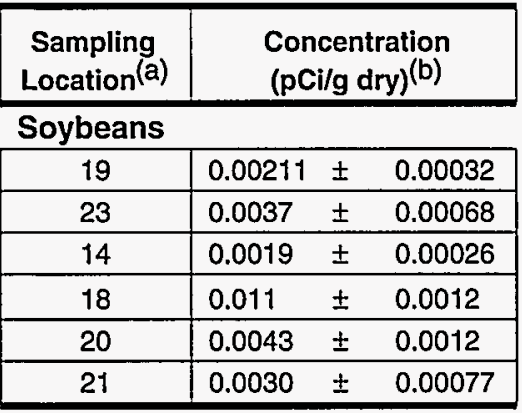

\begin{tabular}{c|c|}
\hline $\begin{array}{c}\text { Sampling } \\
\text { Location }\end{array}$ & $\begin{array}{c}\text { Concentration } \\
\text { (pCi/g dry) }^{(b)}\end{array}$ \\
\hline Cabbage \\
\hline 4 & $0.000043 \pm 0.0000085$ \\
\hline 17 & $<0.000070$ \\
\hline 34 & $0.000089 \pm 0.000014$ \\
\hline
\end{tabular}

\begin{tabular}{|c|c|c|}
\hline $\begin{array}{l}\text { Sampling } \\
\text { Location(a) }\end{array}$ & \multicolumn{2}{|c|}{$\begin{array}{l}\text { Concentration } \\
(\mathrm{pCi} / \mathrm{g} \text { dry })^{(\mathrm{b})}\end{array}$} \\
\hline \multicolumn{3}{|l|}{ Eggplant } \\
\hline 4 & 0.0000090 & \pm 0.0000045 \\
\hline 5 & 0.000097 & \pm 0.00000086 \\
\hline 17 & $<0.000056$ & \\
\hline
\end{tabular}

(a) Locations (see Figure 29 on page 92) are listed in order of increasing distance from the center of the Fernald site production area (Plant 4).

(b) To obtain $\mathrm{Bq} / \mathrm{g}$, multiply $\mathrm{pCi} / \mathrm{g}$ by 0.037 . The plus/minus $( \pm$ ) values are the uncertainty in the analytical results at the $95 \%$ confidence level. 
TABLE 8: Uranium in Milk, 1995

Concentration of Uranium

\begin{tabular}{|c|c|c|c|c|c|c|c|}
\hline \multirow{2}{*}{$\begin{array}{l}\text { Month } \\
\text { January } \\
\end{array}$} & \multicolumn{2}{|c|}{$\begin{array}{l}\text { Local Dairy } \\
\left(^{(p C i / L)^{(a)}}\right.\end{array}$} & \multicolumn{2}{|c|}{$\begin{array}{l}\text { Background Dairy }(\mathrm{b}) \\
(\mathrm{pCi} / \mathrm{L})^{(\mathrm{a})}\end{array}$} & \multicolumn{3}{|c|}{$\begin{array}{c}\text { QC Spike Recovery (pCi/L)(a) } \\
\text { Background Dairy } \\
\text { Expected } \quad \text { Measured } \\
\end{array}$} \\
\hline & $0.00 \pm$ & $\pm \quad 0.10$ & $0.21 \pm$ & 0.10 & 4.7 & $4.8 \pm$ & 1.3 \\
\hline February & 0.32 & $\pm \quad 0.16$ & 0.04 & 0.062 & 4.7 & $5.1 \pm$ & 1.4 \\
\hline
\end{tabular}

(a) To obtain $\mathrm{Bq} / \mathrm{L}$, multiply $\mathrm{pCi} / \mathrm{L}$ by 0.037 . Plus/minus $( \pm$ ) values are the uncertainty in the analytical results at the $95 \%$ confidence level.

(b) Dairy is about $37 \mathrm{~km}$ (23 miles) WSW of the Fernald site. 
TABLE 9: Cattle Tissue Analyses, 1995

Radionuclides in Bone

\begin{tabular}{|l|c|c|}
\hline \multicolumn{1}{|c|}{ Radionuclide } & $\begin{array}{c}\text { Local Farm } \\
\text { (pCi/g) }\end{array}$ & $\begin{array}{c}\text { Background Farm } \\
\text { (pCi/g) }\end{array}$ \\
\hline Uranium-238 & $<0.003$ & $0.039 \pm 0.022$ \\
\hline Uranium-235/236 & $<0.002$ & $<0.002$ \\
\hline Uranium-234 & $<0.02$ & $<0.004$ \\
\hline Thorium-232 & $<0.004$ & $<0.004$ \\
\hline Thorium-230 & $<0.02$ & $<0.01$ \\
\hline Thorium-238 & $0.1 \pm 0.05$ & $0.11 \pm 0.05$ \\
\hline Technetium-99 & $<0.002$ & $<0.002$ \\
\hline Strontium-90 & $0.15 \pm 0.11$ & $<0.04$ \\
\hline Radium-226 & $0.17 \pm 0.08$ & $<0.02$ \\
\hline Plutonium-239/240 & $<0.001$ & $<0.001$ \\
\hline Plutonium-238 & $<0.002$ & $<0.002$ \\
\hline Cesium-137 & $<0.02$ & $<0.02$ \\
\hline
\end{tabular}

Radionuclides in Kidney

\begin{tabular}{|l|c|c|}
\hline \multicolumn{1}{|c|}{ Radionuclide } & \multicolumn{1}{|c|}{$\begin{array}{c}\text { Local Farm } \\
\text { (pCi/g) }\end{array}$} & $\begin{array}{c}\text { Background Farm } \\
\text { (pCi/g) }\end{array}$ \\
\hline Uranium-238 & $0.003 \pm 0.002$ & $0.01 \pm 0.003$ \\
\hline Uranium-235/236 & $<0.001$ & $0.003 \pm 0.002$ \\
\hline Uranium-234 & $0.01 \pm 0.003$ & $0.01 \pm 0.004$ \\
\hline Thorium-232 & $<0.002$ & $<0.002$ \\
\hline Thorium-230 & $<0.01$ & $<0.01$ \\
\hline Thorium-228 & $0.01 \pm 0.004$ & $<0.003$ \\
\hline Technetium-99 & $<0.03$ & $<0.04$ \\
\hline Strontium-90 & $<0.06$ & $<0.06$ \\
\hline Radium-226 & $<0.02$ & $<0.02$ \\
\hline Plutonium-239/240 & $<0.001$ & $<0.001$ \\
\hline Plutonium-238 & $<0.001$ & $<0.001$ \\
\hline Cesium-137 & $<0.02$ & $<0.02$ \\
\hline
\end{tabular}

(a) To obtain $B q / L$, multiply $\mathrm{pCi} / \mathrm{L}$ by 0.037 . Plus/minus ( \pm ) values are the uncertainty in the analytical results at the $95 \%$ confidence level.
(b) Dairy is about $37 \mathrm{~km}$ (23 miles) WSW of the Fernald site.

Radionuclides in Liver

\begin{tabular}{|l|c|c|}
\hline \multicolumn{1}{|c|}{ Radionuclide } & $\begin{array}{c}\text { Local Farm } \\
\text { (pCi/g) }\end{array}$ & $\begin{array}{c}\text { Background Farm } \\
\text { (pCi/g) }\end{array}$ \\
\hline Uranium-238 & $<0.004$ & $0.02 \pm 0.01$ \\
\hline Uranium-235/236 & $<0.004$ & $0.03 \pm 0.02$ \\
\hline Uranium-234 & $<0.01$ & $0.13 \pm 0.05$ \\
\hline Thorium-232 & $<0.01$ & $<0.01$ \\
\hline Thorium-230 & $<0.06$ & $<0.04$ \\
\hline Thorium-228 & $<0.02$ & $<0.01$ \\
\hline Technetium-99 & $<0.03$ & $<0.1$ \\
\hline Strontium-90 & $<0.08$ & $<0.02$ \\
\hline Radium-226 & $<0.03$ & $<0.01$ \\
\hline Plutonium-239/240 & $<0.03$ & $<0.01$ \\
\hline Plutonium-238 & $<0.05$ & $<0.02$ \\
\hline Cesium-137 & $<0.02$ & $<0.02$ \\
\hline
\end{tabular}

Radionuclides in Meat

\begin{tabular}{|l|c|c|}
\hline \multicolumn{1}{|c|}{ Radionuclide } & \multicolumn{1}{|c|}{$\begin{array}{c}\text { Local Farm } \\
(\mathbf{p C i} / \mathrm{g})\end{array}$} & $\begin{array}{c}\text { Background Farm } \\
(\mathrm{pCi} / \mathrm{g})\end{array}$ \\
\hline Uranium-238 & $<0.004$ & $0.0004 \pm 0.0003$ \\
\hline Uranium-235/236 & $<0.01$ & $<0.0003$ \\
\hline Uranium-234 & $<0.01$ & $<0.001$ \\
\hline Thorium-232 & $<0.01$ & $<0.01$ \\
\hline Thorium-230 & $<0.03$ & $<0.07$ \\
\hline Thorium-228 & $<0.01$ & $<0.02$ \\
\hline Technetium-99 & $<0.04$ & $<0.06$ \\
\hline Strontium-90 & $<0$ & $<0.01$ \\
\hline Radium-226 & $<0.03$ & $0.004 \pm 0.003$ \\
\hline Plutonium-239/240 & $<0.003$ & $<0.01$ \\
\hline Plutonium-238 & $<0.004$ & $<0.01$ \\
\hline Cesium-137 & $<0.02$ & $<0.02$ \\
\hline
\end{tabular}


TABLE 10: Environmental TLD Direct Radiation Measurements, 1995

\begin{tabular}{|c|c|c|c|}
\hline Location Description(a) & $\begin{array}{l}\text { Location } \\
\text { Number }\end{array}$ & $\begin{array}{l}1995 \text { Dose Rate } \\
(\mathrm{mrem} / \mathrm{yr})(\mathrm{b}, \mathrm{c})\end{array}$ & $\begin{array}{l}1994 \text { Dose Rate } \\
(\mathrm{mrem} / \mathrm{yr})^{(\mathrm{b}, \mathrm{c})}\end{array}$ \\
\hline \multicolumn{4}{|l|}{ Fenceline } \\
\hline AMS 2 & 2 & $70 \pm 4.1$ & $70 \pm 1.5$ \\
\hline AMS 3 & 3 & $62 \pm 3.6$ & $61 \pm 1.5$ \\
\hline AMS 4 & 4 & $61 \pm 3.6$ & $64 \pm 1.2$ \\
\hline AMS 5 & 5 & $65 \pm 3.8$ & $65 \pm 5.9$ \\
\hline AMS 6 & 6 & $70 \pm 4.1$ & $67 \pm 2.5$ \\
\hline AMS 7 & 7 & $64 \pm 3.7$ & $62 \pm 1.5$ \\
\hline Site fenceline near K-65 silos & 13 & $68 \pm 4.0$ & $66 \pm 1.5$ \\
\hline Site fenceline near K-65 silos & 14 & $66 \pm 3.9$ & $63 \pm 1.2$ \\
\hline Site fenceline near K-65 silos & 15 & $68 \pm 4.0$ & $67 \pm 1.9$ \\
\hline Site fenceline near K-65 silos & 16 & $70 \pm 4.1$ & $66 \pm 1.4$ \\
\hline Site fenceline near K-65 silos & 17 & $67 \pm 3.9$ & $62 \pm 2.5$ \\
\hline
\end{tabular}

\section{Onsite}

\begin{tabular}{|l|r|r|r|}
\hline AMS 1A & $1 \mathrm{~A}$ & $130 \pm 7.8$ & $110 \pm 2.3$ \\
\hline AMS 8 & 8 & $64 \pm 3.8$ & $63 \pm 1.6$ \\
\hline AMS 9 & 9 & $89 \pm 5.2$ & $89 \pm 4.2$ \\
\hline K-65 perimeter fence & 22 & $450 \pm 26$ & $320 \pm 17$ \\
\hline K-65 perimeter fence & 23 & $430 \pm 25$ & $300 \pm 14$ \\
\hline K-65 perimeter fence & 24 & $280 \pm 16$ & $190 \pm 6.1$ \\
\hline K-65 perimeter fence & 25 & $330 \pm 19$ & $260 \pm 9.6$ \\
\hline K-65 perimeter fence & 26 & $250 \pm 14$ & $170 \pm 6.8$ \\
\hline OSH Building, Room $218{ }^{(d)}$ & 32 & $51 \pm 3.0$ & $49 \pm 1.2$ \\
\hline
\end{tabular}

\section{Offsite}

\begin{tabular}{|l|c|c|c|}
\hline AMS 10 & 10 & $52 \pm 3.0$ & $50 \pm 0.9$ \\
\hline AMS 11 & 11 & $64 \pm 3.7$ & $63 \pm 1.4$ \\
\hline AMS 13 & 12 & $56 \pm 3.3$ & $56 \pm 1.9$ \\
\hline Westwood, OH (e) & 18 & $71 \pm 4.2$ & $65 \pm 1.3$ \\
\hline Brookville, IN & 19 & $59 \pm 3.5$ & $58 \pm 1.1$ \\
\hline AMS 15, Miamitown & 20 & $56 \pm 3.3$ & $59 \pm 2.4$ \\
\hline AMS 16, University of Cincinnati & 21 & $66 \pm 3.9$ & $57 \pm 1.2$ \\
\hline AMS 12 & 27 & $59 \pm 3.4$ & $57 \pm 1.0$ \\
\hline REM Field Office, Harrison, OH & 30 & $58 \pm 3.4$ & $57 \pm 0.9$ \\
\hline Background in Fairfield & 33 & $68 \pm 4.0$ & $66 \pm 1.1$ \\
\hline
\end{tabular}

(a) See Figure 30 on page 95 for locations.

(b) Plus/minus ( \pm ) values are the uncertainty in the analytical results at the $95 \%$ confidence level.

(c) Dose is calculated from the sum of quarterly measurements at each location.

(d) TLDs 32 is located inside a building and is used as a control location.

(e) 1995 dose for location 18 is based on three quarterly measurements. 
$N$
$\mathscr{D}$
$\stackrel{\mathbb{R}}{0}$
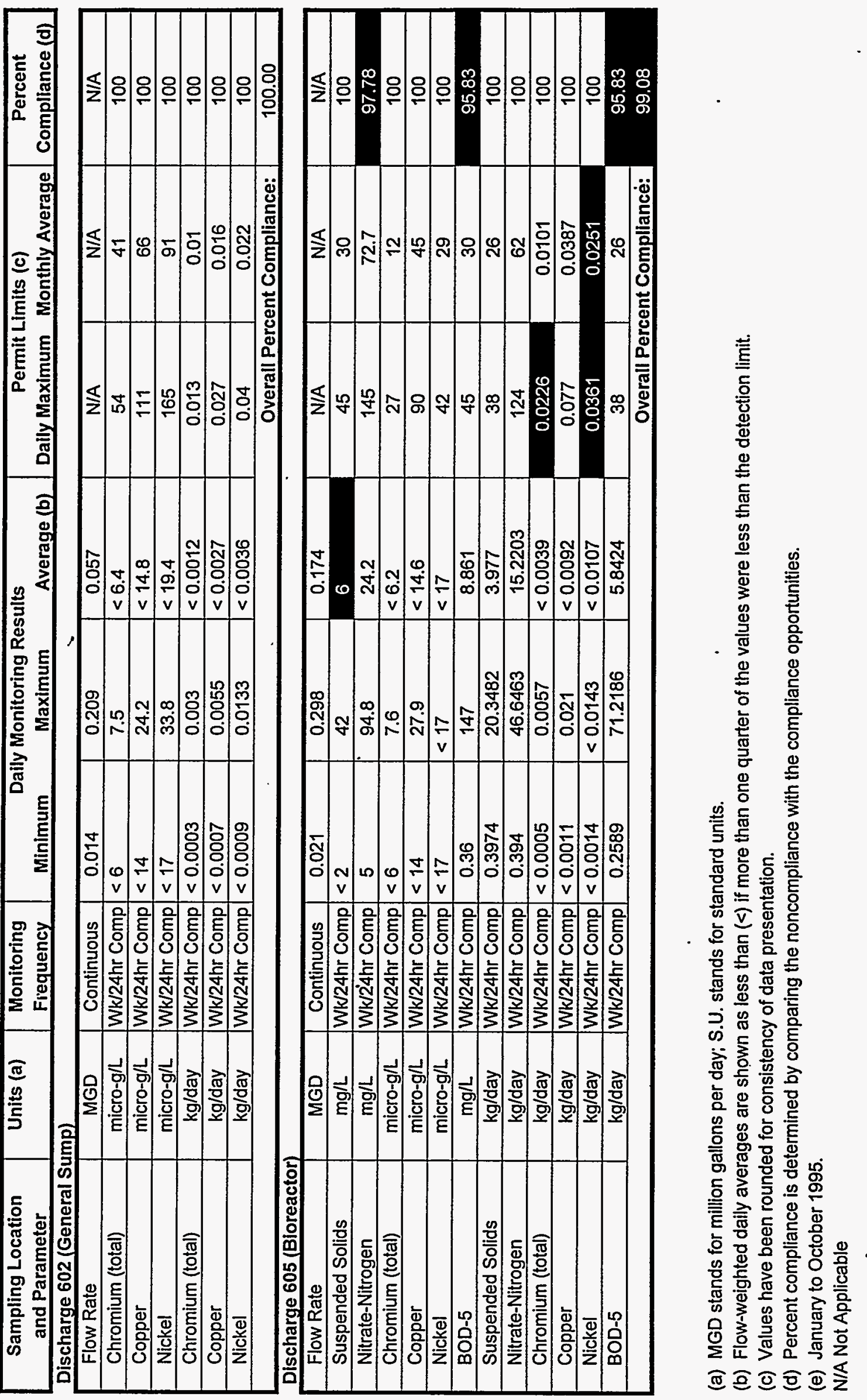



\begin{tabular}{|c|c|c|c|c|c|c|c|c|}
\hline $\begin{array}{l}\text { Sampling Location } \\
\text { and Parameter }\end{array}$ & Units(a) & $\begin{array}{c}\text { Monitoring } \\
\text { Requirements }\end{array}$ & \multicolumn{3}{|c|}{ Daily Monitoring Results } & \multicolumn{2}{|c|}{$\begin{array}{c}\text { Permit Limits (c) } \\
\text { Daily Maximum Monthly Average }\end{array}$} & $\begin{array}{c}\text { Percent } \\
\text { Compliance }(d)\end{array}$ \\
\hline \multicolumn{9}{|c|}{ Discharge 601 (Sewage Treatment Plant) } \\
\hline Flow Rate & MGD & Continuous & 0.018 & 0.332 & 0.127 & N/A & N/A & $\mathrm{N} / \mathrm{A}$ \\
\hline Suspended Solids & $\mathrm{mg} / \mathrm{L}$ & Wk/24hr Comp & $<2$ & 12 & 3 & 40 & 20 & 100.0 \\
\hline Fecal Coliform(e) & $\# \mathrm{Col} / 100 \mathrm{ml}$ & Wk/24hr Comp & 0 & 3,000 & 32 & 2,000 & 1,000 & 100.0 \\
\hline BOD-5 & $\mathrm{mg} / \mathrm{L}$ & Wk/24hr Comp & 0.26 & 25.08 & 6.17 & 40 & 20 & 100.0 \\
\hline Suspended Solids & $\mathrm{kg} /$ day & Wk/24hr Comp & $<0.4239$ & 4.0537 & $<1.2954$ & 19 & 9.5 & 100.0 \\
\hline BOD-5 & $\mathrm{kg} / \mathrm{day}$ & Wk/24hr Comp & 0.064 & 13.9544 & 3.3288 & 19 & 9.5 & 100.0 \\
\hline \multicolumn{8}{|c|}{ Percent Compliance } & 100.0 \\
\hline \multicolumn{9}{|c|}{ Discharge 602 (General Sump) } \\
\hline Flow Rate & MGD & Continuous & 0.014 & 0.209 & 0.057 & $N / A$ & N/A & $\mathrm{N} / \mathrm{A}$ \\
\hline Chromium (total) & $\mu \mathrm{g} / \mathrm{L}$ & Wk/24hr Comp & $<6.0$ & 7.5 & $<6.4$ & 54 & 41 & 100.0 \\
\hline Copper & $\mu \mathrm{g} / \mathrm{L}$ & $\mathrm{Wk} / 24 \mathrm{hr}$ Comp & $<14.0$ & 24.2 & $<14.8$ & 111 & 66 & 100.0 \\
\hline Nickel & $\mu \mathrm{g} / \mathrm{L}$ & Wk/24hr Comp & $<17.0$ & 33.8 & $<19.4$ & 165 & 91 & 100.0 \\
\hline Chromium (total) & $\mathrm{kg} / \mathrm{day}$ & Wk/24hr Comp & $<0.0003$ & 0.003 & $<0.0012$ & 0.013 & 0.01 & 100.0 \\
\hline Copper & $\mathrm{kg} /$ day & Wk/24hr Comp & $<0.0007$ & 0.0055 & $<0.0027$ & 0.027 & 0.016 & 100.0 \\
\hline Nickel & $\mathrm{kg} /$ day & Wk/24hr Comp & $<0.0009$ & 0.0133 & $<0.0036$ & 0.04 & 0.022 & 100.0 \\
\hline \multicolumn{8}{|c|}{ Percent Compliance } & 100.0 \\
\hline
\end{tabular}




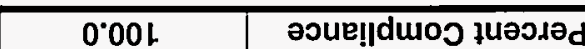

\begin{tabular}{|c|c|c|c|c|c|c|c|c|}
\hline 0.001 & $\forall / N$ & 9.11 & $0.01>$ & $0.01>$ & $0.01>$ & dயOว/นəА & $7 / 6 n$ & גəA!!S \\
\hline 0.001 & $\forall / N$ & $\angle \varepsilon L^{\prime} \varepsilon$ & $0 \angle L>$ & $0.21>$ & $0 . \angle t>$ & dயOO/АUəА & $7 / 6 n$ & |əYण!N \\
\hline 0.001 & $\forall / N$ & st & $0^{\circ} \geqslant t>$ & $0.01>$ & $0.01>$ & dயоОАนәภヨ & $7 / 6 n$ & ləddoว \\
\hline 0.001 & $\forall / N$ & Gl & $0^{\circ} 9>$ & $0 \cdot 9>$ & $0.9>$ & qедפภนว^ヨ & $7 / 6 m$ & әรеәม $81 ! 0$ \\
\hline 0.001 & $\forall / N$ & 61 & $0.9>$ & $0.9>$ & $0.9>$ & dแ0ว/Иข^ヨ & $7 / 6 n^{\prime}$ & $(9+)$ un!̣od40 \\
\hline 0.001 & $\forall / N$ & $986^{\prime} \varepsilon$ & $9.9>$ & $1 \cdot 2$ & $9>$ & 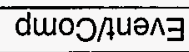 & $7 / 6 n$ & (|eł0|) un!̣uod4ว \\
\hline 0.001 & $\forall / N$ & 001 & $1 t$ & 99 & 91 & duoว/นә^ヨ & $7 / 6 m$ & sp!los papuədsns \\
\hline 0.001 & \multicolumn{2}{|c|}{0.6 이 $9^{\circ} 9=$ ebuey } & $\forall / N$ & 0.8 & $t L$ & qедэภนวл & $n \cdot s$ & $\mathrm{H}^{\mathrm{d}}$ \\
\hline$\forall / N$ & $\forall / N$ & $\forall / N$ & $82 Z^{\prime} t$ & $\angle 99^{\circ} \mathrm{L}$ & $82 t \div 0$ & әүещ!!s $\exists$ & aפW & 라버 MOIJ \\
\hline
\end{tabular}

(uny sKpped of Kem|l!ds) Z00 әб.ецәs!ด

\begin{tabular}{|c|c|c|c|c|c|c|c|c|}
\hline$\varepsilon \varepsilon^{\prime} 66$ & osue!|duso & & & & & & & \\
\hline 0.001 & 99 & 66 & $\nabla \angle 6 S^{\prime} L$ & $9 \angle 60^{\circ} 9$ & s8\&ट”0 & dwo $d Y \rightarrow Z / A M$ & Кер/Бя & $0-008$ \\
\hline 0.001 & $\angle \angle O^{\circ} 0$ & $1 \varepsilon^{\prime} 0$ & $9800^{\circ} 0>$ & $\angle D 10^{\circ} 0$ & $0 \varepsilon 00^{\circ} 0>$ & 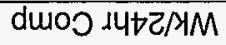 & Кер/Бу & deddoo \\
\hline 0.001 & $0 S$ & $0 S$ & $1206^{\prime} Z>$ & 9GES'S & $8690^{\circ} \downarrow>$ & qеגפ/К|४әә & Кер/Бя & әseәגり 8 \\
\hline $0.00 \mathrm{t}$ & 66 & $6+t$ & $\left.\angle \downarrow G Z Z^{\prime} \downarrow\right\rangle$ & ZSLL'St & $8 \angle 99^{\circ} 0>$ & dwo $d 4 t Z / M M$ & Кер/Бу & sp!|os pepuedsns \\
\hline 0.001 & $0 z$ & $0 \varepsilon$ & $89^{\circ} Z$ & $6 \angle t$ & $\varepsilon^{\prime} 0$ & duoJ $d U \triangleright Z / A M$ & $7 /$ कw & $0-008$ \\
\hline 0.001 & $\varepsilon 己$ & 76 & 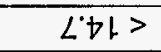 & $6^{\prime}+2$ & $0 \circ \geqslant 1>$ & duroJ $14 \not z / M M$ & $7 / 6 n$ & leddo \\
\hline 0.001 & Gt & St & $L \cdot G>$ & 9.9 & $0.9>$ & qеגפ/К|४әәМ & $7 / 6 u$ & әseəגอ 8I!O \\
\hline 0.86 & $0 \varepsilon$ & st & $L>$ & 19 & $z>$ & duo $d u t Z / A M$ & $7 / \overline{6}$ & sp!|os pepuedsns \\
\hline $1 \varepsilon^{\circ} 96$ & \multicolumn{2}{|c|}{$0.9=$ unu!̣!!N } & 9.8 & 6.6 & $\varepsilon \%$ & qеגэ/К|нәәМ & $7 / 6 m$ & uebKXO pan|Oss!O \\
\hline 0.001 & \multicolumn{2}{|c|}{0.6 이 $9^{\prime} 9=$ - ә6uey } & $\forall / N$ & 9.11 & 9.9 & snonu!nuo & $n \cdot s$ & $\mathrm{Hd}^{\mathrm{d}}$ \\
\hline$\forall / N$ & $\forall / N$ & $\forall / N$ & 9.0 & $\angle \angle 9^{\prime} 0$ & ¿ह0.0 & snonu!nuoj & QOW & 카러 $\mathrm{MO}$ 의 \\
\hline
\end{tabular}

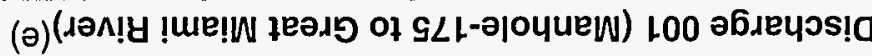

\begin{tabular}{|c|c|c|c|c|c|}
\hline $\begin{array}{l}\text { (p) osue!|duros } \\
\text { fuesded }\end{array}$ & 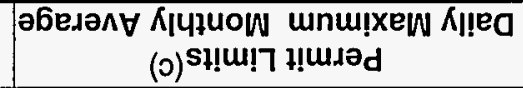 & 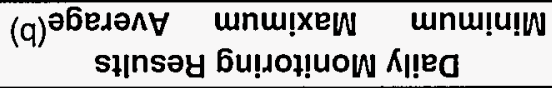 & $\begin{array}{l}\text { słuawad!nbəy } \\
\text { 6u!גo!!uow }\end{array}$ & $\left(e^{\text {st!un }}\right.$ & $\begin{array}{c}\text { seloweded pue } \\
\text { uo!̣eoo } 7 \text { 6u!ldures }\end{array}$ \\
\hline
\end{tabular}




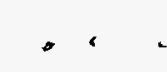


Table 11: NPDES Data, 1995

\begin{tabular}{|c|c|c|c|c|c|c|c|c|}
\hline \multirow{2}{*}{$\begin{array}{c}\text { Sampling Location } \\
\text { and Parameter }\end{array}$} & \multirow[t]{2}{*}{ Units (a) } & \multirow{2}{*}{$\begin{array}{l}\text { Monitoring } \\
\text { Frequency }\end{array}$} & \multicolumn{3}{|c|}{ Daily Monitoring Results } & \multicolumn{2}{|c|}{ Permit Limits (c) } & \multirow{2}{*}{$\begin{array}{c}\text { Percent } \\
\text { Compliance (d) }\end{array}$} \\
\hline & & & Minimum & Maximum & Average (b) & Daily Maximum & Monthly Average & \\
\hline \multicolumn{9}{|c|}{ Discharge 001 (Manhole-175 to Great Miami River) (e) } \\
\hline Flow Rate & MGD & Continuous & 0.032 & 0.677 & 0.16 & N/A & N/A & N/A \\
\hline $\mathrm{pH}$ & S.U. & Continuous & 5.6 & 11.6 & N/A & \multicolumn{2}{|c|}{ Range $=6.5$ to 9.0} & 95.31 \\
\hline Dissolved Oxygen & $\mathrm{mg} / \mathrm{L}$ & Weekly/Grab & 5.3 & 9.9 & 8.2 & \multicolumn{2}{|c|}{ Minimum $=5.0$} & 100 \\
\hline Suspended Solids & $\mathrm{mg} / \mathrm{L}$ & Wk/24hr Comp & $<2$ & 61 & $<7$ & 45 & 30 & 98 \\
\hline Oil \& Grease & $\mathrm{mg} / \mathrm{L}$ & Weekly/Grab & $<5$ & 6.5 & $<5.1$ & 15 & 15 & 100 \\
\hline Copper & micro-g/L & Wk/24hr Comp & $<14$ & 24.9 & $<14.7$ & 94 & 23 & 100 \\
\hline BOD-C & $\mathrm{mg} / \mathrm{L}$ & Wk/24hr Comp & 0.3 & 17.9 & 2.58 & 30 & 20 & 100 \\
\hline Suspended Solids & $\mathrm{kg} / \mathrm{day}$ & Wk/24hr Comp & $<0.5678$ & 45.7152 & $<4.2547$ & 149 & 99 & 100 \\
\hline Oil \& Grease & $\mathrm{kg} /$ day & Weekly/Grab & $<1.0598$ & 5.5356 & $<2.9021$ & 50 & 50 & 100 \\
\hline Copper & $\mathrm{kg} / \mathrm{day}$ & Wk/24hr Comp & $<0.003$ & 0.0147 & $<0.0085$ & 0.31 & 0.077 & 100 \\
\hline BOD-C & $\mathrm{kg} / \mathrm{day}$ & Wk/24hr Comp & 0.2385 & 6.0976 & 1.5974 & 99 & 66 & 100 \\
\hline \multicolumn{8}{|c|}{ Overall Percent Compliance: } & 97.18 \\
\hline \multicolumn{9}{|c|}{ Discharge 002 (Spillway to Paddys Run) (e) } \\
\hline Flow Rate & MGD & Estimate & 0.428 & 1.657 & 1.228 & N/A & N/A & N/A \\
\hline $\mathrm{pH}$ & S.U. & Event/Grab & 7.4 & 8 & N/A & \multicolumn{2}{|c|}{ Range $=6.5$ to 9.0} & 100 \\
\hline Suspended Solids & $\mathrm{mg} / \mathrm{L}$ & Event/Comp & 16 & 65 & 41 & 100 & N/A & 100 \\
\hline Chromium (total) & micro-g/L & Event/Comp & $<6$ & 7.1 & $<6.5$ & 3,986 & N/A & 100 \\
\hline Chromium (+6) & micro-g/L & Event/Comp & $<6$ & $<6$ & $<6$ & 19 & N/A & 100 \\
\hline Oil \& Grease & $\mathrm{mg} / \mathrm{L}$ & Event/Grab & $<5$ & $<5$ & $<5$ & 15 & N/A & 100 \\
\hline Copper & micro-g/L & Event/Comp & $<14$ & $<14$ & $<14$ & 45 & N/A & 100 \\
\hline Nickel & micro-g/L & Event/Comp & $<17$ & $<17$ & $<17$ & 3,137 & N/A & 100 \\
\hline Silver & micro-g/L & Event/Comp & $<10$ & $<10$ & $<10$ & 11.6 & N/A & 100 \\
\hline \multicolumn{8}{|c|}{ Overall Percent Compliance: } & 100.00 \\
\hline \multicolumn{9}{|c|}{ Discharge 601 (Sewage Treatment Plant) (e) } \\
\hline Flow Rate & MGD & Continuous & 0.018 & 0.332 & 0.127 & N/A & N/A & N/A \\
\hline Suspended Solids & $\mathrm{mg} / \mathrm{L}$ & Wk/24hr Comp & $<2$ & 12 & $<3$ & 40 & 20 & 100 \\
\hline Fecal Coliform & $\# \mathrm{col} / 100 \mathrm{ml}$ & Wk/24hr Comp & 0 & 3000 & 32 & 2,000 & 1,000 & 93.33 \\
\hline BOD-5 & $\mathrm{mg} / \mathrm{L}$ & Wk/24hr Comp & 0.26 & 25.08 & 6.17 & 40 & 20 & 100 \\
\hline Suspended Solids & $\mathrm{kg} /$ day & Wk/24hr Comp & $<0.4239$ & 4.0537 & $<1.2954$ & 19 & 9.5 & 100 \\
\hline BOD-5 & $\mathrm{kg} / \mathrm{day}$ & Wk/24hr Comp & 0.064 & 13.9544 & 3.3288 & 19 & 9.5 & 100 \\
\hline \multicolumn{8}{|c|}{ Overall Percent Compliance: } & 99.16 \\
\hline
\end{tabular}




\begin{tabular}{|c|c|c|c|c|c|c|c|c|}
\hline $\begin{array}{l}\text { Sampling Location } \\
\text { and Parameter }\end{array}$ & Units(a) & $\begin{array}{c}\text { Monitoring } \\
\text { Requirements }\end{array}$ & \multicolumn{3}{|c|}{ Daily Monitoring Results } & \multicolumn{2}{|c|}{$\begin{array}{c}\text { Permit Limits }(c) \\
\text { Daily Maximum Monthly Average }\end{array}$} & $\begin{array}{c}\text { Percent } \\
\text { Compliance }(\mathrm{d})\end{array}$ \\
\hline \multicolumn{9}{|c|}{ Discharge 605 (Bioreactor) } \\
\hline Flow Rate & MGD & Continuous & 0.021 & 0.298 & 0.174 & N/A & $\mathrm{N} / \mathrm{A}$ & N/A \\
\hline Suspended Solids & $\mathrm{mg} / \mathrm{L}$ & Wk/24hr Comp & $<2$ & 42 & $<6$ & 45 & 30 & 100.0 \\
\hline Nitrate-Nitrogen & $\mathrm{mg} / \mathrm{L}$ & Wk/24hr Comp & 5 & 94.8 & 24.2 & 145 & 72.7 & 100.0 \\
\hline Chromium (total) & $\mu \mathrm{g} / \mathrm{L}$ & Wk/24hr Comp & $<6.0$ & 7.6 & $<6.2$ & 27 & 12 & 100.0 \\
\hline Copper & $\mu g / L$ & Wh/24hr Comp & $<14.0$ & 27.9 & $<14.6$ & 90 & 45 & 100.0 \\
\hline Nickel & $\mu g / L$ & Wk/24hr Comp & $<17.0$ & $<17.0$ & $<17.0$ & 42 & 29 & 100.0 \\
\hline BOD-5 & $\mathrm{mg} / \mathrm{L}$ & Wh/24hr Comp & 0.36 & 147 & 8.861 & 45 & 30 & 100.0 \\
\hline Suspended Solids & $\mathrm{kg} / \mathrm{day}$ & Wh/24hr Comp & 0.3974 & 20.3482 & 3.977 & 38 & 26 & 100.0 \\
\hline Nitrate-Nitrogen & $\mathrm{kg} /$ day & Wk/24hr Comp & 0.394 & 46.6463 & 15.2203 & 124 & 62 & 100.0 \\
\hline Chromium (total) & $\mathrm{kg} / \mathrm{day}$ & Wh/24hr Comp & $<0.0005$ & 0.0057 & $<0.0039$ & 0.022 & 0.0101 & 100.0 \\
\hline Copper & $\mathrm{kg} / \mathrm{day}$ & Wh/24hr Comp & $<0.0011$ & 0.021 & $<0.0092$ & 0.077 & 0.0387 & 100.0 \\
\hline Nickel & $\mathrm{kg} /$ day & Wk/24hr Comp & $<0.0014$ & $<0.0143$ & $<0.0107$ & 0.036 & 0.025 & 100.0 \\
\hline BOD-5 & $\mathrm{kg} / \mathrm{day}$ & Wk/24hr Comp & 0.2589 & 71.2186 & 5.8424 & 38 & 26 & 100.0 \\
\hline \multicolumn{8}{|c|}{ Percent Compliance } & 100.0 \\
\hline
\end{tabular}

(a) MGD stands for million gallons per day, and S.U. stands for standard units.

(b) Flow-weighted daily averages are shown as less than $(<)$ if more than one quarter of the values were less than the detection limit.

(c) Values have been rounded for consistency of data presentation.

(d) Percent compliance is determined by comparing the noncompliance with the compliance opportunities.

(e) January to October 1995.

N/A Not applicable.

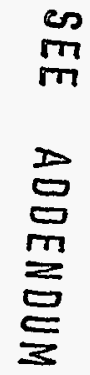


TABLE 12: Radionuclides Discharged to the Great Miami River, 1995

Manhole-175/Parshall Flume (a)

\begin{tabular}{|l|c|c|c|c|}
\hline Radionuclide $(\mathrm{b})$ & $\begin{array}{c}\text { Total Curies } \\
\mathbf{1 9 9 5}\end{array}$ & $\begin{array}{c}\text { 1995 Average Concentration } \\
(\mathrm{pCi} / \mathrm{L})^{(\mathrm{c})}\end{array}$ & $\begin{array}{c}\text { Standard } \\
\mathrm{pCi} / \mathrm{L}\end{array}$ & $\begin{array}{c}\text { Percent } \\
\text { of Standard }(\mathrm{e})\end{array}$ \\
\hline Actinium-228 ${ }^{(\mathrm{f})}$ & $<0.00063$ & $<2.7$ & 60,000 & $<0.0045$ \\
\hline Radium-224(g) & $<0.00002$ & $<0.06$ & 400 & $<0.015$ \\
\hline Radium-226 & $<0.00003$ & $<0.1$ & 100 & $<0.10$ \\
\hline Radium-228 & $<0.00063$ & $<2.7$ & 100 & $<2.7$ \\
\hline Thorium-228 & $<0.00002$ & $<0.06$ & 400 & $<0.015$ \\
\hline Thorium-230 & $<0.000012$ & $<0.05$ & 300 & $<0.017$ \\
\hline Thorium-237(h) & 0.0004 & 1.60 & 100,000 & 0.0016 \\
\hline Thorium-232 & $<0.000005$ & $<0.02$ & 50 & $<0.04$ \\
\hline Thorium-234(i) & 0.004 & 17.40 & 10,000 & 0.174 \\
\hline Uranium-234 & 0.004 & 16.20 & 500 & 3.2 \\
\hline Uranium-235 & 0.0004 & 1.60 & 600 & 0.27 \\
\hline Uranium-236(j) & 0.0002 & 0.90 & 500 & 0.18 \\
\hline Uranium-238 & 0.004 & 17.40 & 600 & 2.9 \\
\hline
\end{tabular}

South Plume (SP3)

\begin{tabular}{|l|c|c|c|c|}
\hline \multicolumn{1}{|c|}{ Radionuclide $(\mathrm{b})$} & $\begin{array}{c}\text { Total Curies } \\
\mathbf{1 9 9 5}\end{array}$ & $\begin{array}{c}\text { 1995 Average Concentration } \\
(\mathrm{pCi} / \mathrm{L})\end{array}$ & $\begin{array}{c}\text { Standard(d) } \\
\text { pCi/L }\end{array}$ & $\begin{array}{c}\text { Percent } \\
\text { of Standard }(\mathrm{e})\end{array}$ \\
\hline Actinium-228(f) & $<0.0068$ & $<2.71$ & 60,000 & $<0.0045$ \\
\hline Radium-224(g) & $<0.00013$ & $<0.05$ & 400 & $<0.0125$ \\
\hline Radium-226 & $<0.00053$ & $<0.21$ & 100 & 0.21 \\
\hline Radium-228 & $<0.0068$ & $<2.71$ & 100 & $<2.705$ \\
\hline Thorium-228 & $<0.00013$ & $<0.05$ & 400 & $<0.0125$ \\
\hline Thorium-230 & $<0.00023$ & $<0.09$ & 300 & $<0.03$ \\
\hline Thorium-231(h) & 0.0017 & 0.68 & 100,000 & 0.0007 \\
\hline Thorium-232 & $<0.00005$ & $<0.02$ & 50 & $<0.04$ \\
\hline Thorium-234(i) & 0.036 & 14.46 & 10,000 & 0.145 \\
\hline Uranium-234 & 0.031 & 12.41 & 500 & 2.482 \\
\hline Uranium-235 & 0.0017 & 0.68 & 600 & 0.113 \\
\hline Uranium-236(j) & 0.0009 & 0.34 & 500 & 0.068 \\
\hline Uranium-238 & 0.036 & 14.46 & 600 & 2.411 \\
\hline
\end{tabular}

(a) Effective November 1, 1995, Parshall Flume replaced Manhole-175 as monitoring location for discharges to the Great Miami River.

(b) Radionuclide concentrations in the plant effluent discharged to the Great Miami River through the pipeline are determined from monthly or quarterly composites of daily, 24-hour continuous samples.

(c) Averages are flow-weighted. To obtain $\mathrm{Bq} / \mathrm{L}$, multiply by 0.037 .

(d) As stated in DOE Order 5400.5, "Radiation Protection of the Public and the Environment."

(e) Percent of standard relates to the average concentration. Where less than $(<)$ is reported, the maximum possible value is assumed.

(f) Calculated based on radioactive decay equilibrium with radium-228.

(g) Calculated based on radioactive decay equilibrium with thorium-228.

(h) Calculated based on radioactive decay equilibrium with uranium-235.

(i) Calculated based on radioactive decay equilibrium with uranium-238.

(j) Calculated based on historical concentration ratios of uranium-235 to uranium-236. 
TABLE 13: Radionuclides in Surface Water, 1995

Page 1 of 2

\begin{tabular}{|c|c|c|c|c|c|c|c|c|c|}
\hline Parameter & $\begin{array}{c}\text { Sampling } \\
\text { Location(a) }\end{array}$ & $\begin{array}{c}\text { Number } \\
\text { of Samples }\end{array}$ & \multicolumn{3}{|c|}{ Concentration $(\mathrm{pCi} / \mathrm{L})^{(\mathrm{b})}$} & $\begin{array}{l}\text { Standards } \\
(\mathrm{pCi} / \mathrm{L})^{(\mathrm{c})}\end{array}$ & \multicolumn{3}{|c|}{ Percent of Standard } \\
\hline \multicolumn{10}{|l|}{ Great Miami River } \\
\hline \multicolumn{10}{|l|}{ Total Uranium } \\
\hline Upstream of Effluent Line & W1 & 49 & $<0.70$ & 1.80 & $<1.10$ & 550 & $<0.13$ & 0.33 & $<0.20$ \\
\hline Downstream of Effluent Line & W3 & 52 & $<0.70$ & 1.90 & $<1.10$ & 550 & $<0.13$ & 0.35 & $<0.20$ \\
\hline Downstream of Effluent Line & W4 & 48 & $<0.70$ & 3.20 & $<1.20$ & 550 & $<0.13$ & 0.58 & $<0.22$ \\
\hline \multicolumn{10}{|l|}{ Radium-226(d) } \\
\hline Upstream of Effluent Line & W1 & 12 & 0.07 & 0.29 & 0.18 & 100 & 0.07 & 0.29 & 0.18 \\
\hline Downstream of Effluent Line & W3 & 12 & 0.10 & 0.28 & 0.17 & 100 & 0.10 & 0.28 & 0.17 \\
\hline Downstream of Effluent Line & W4 & 12 & $<0.05$ & 0.29 & $<0.17$ & 100 & $<0.05$ & 0.29 & 0.17 \\
\hline \multicolumn{10}{|l|}{ Radium-228(d) } \\
\hline Upstream of Effluent Line & W1 & 12 & $<1.10$ & 7.10 & $<3.70$ & 100 & $<1.10$ & 7.10 & $<3.70$ \\
\hline Downstream of Effluent Line & W3 & 12 & $<0.30$ & 3.80 & $<2.60$ & 100 & $<0.30$ & 3.80 & $<2.60$ \\
\hline Downstream of Effluent Line & W4 & 12 & $<0.20$ & 5.20 & $<2.00$ & 100 & $<0.20$ & 5.20 & $<2.00$ \\
\hline \multicolumn{10}{|l|}{ Strontium-90(d) } \\
\hline Upstream of Effluent Line & W1 & 2 & 0.09 & 0.19 & 0.14 & 1,000 & 0.009 & 0.019 & 0.014 \\
\hline Downstream of Effluent Line & W3 & 2 & 0.10 & 0.2 & 0.15 & 1,000 & 0.01 & 0.02 & 0.015 \\
\hline Downstream of Effluent Line & W4 & 2 & 0.11 & 1.2 & 0.66 & 1,000 & 0.011 & 0.12 & 0.0655 \\
\hline \multicolumn{10}{|l|}{ Cesium-137(d)(e) } \\
\hline Upstream of Effluent Line & W1 & 2 & $<M D C$ & $<\mathrm{MDC}$ & $<M D C$ & 3,000 & $<0.0057$ & $<0.0097$ & $<0.0077$ \\
\hline Downstream of Effluent Line & W3 & 2 & $<\mathrm{MDC}$ & $\leq \mathrm{MDC}$ & $<M D C$ & 3,000 & $<0.0067$ & $<0.0233$ & $<0.0150$ \\
\hline Downstream of Effluent Line & W4 & 2 & $<\mathrm{MDC}$ & $<\mathrm{MDC}$ & $<\mathrm{MDC}$ & 3,000 & $<0.0080$ & $<0.0227$ & $<0.0154$ \\
\hline \multicolumn{10}{|l|}{ Technetium-99(d) } \\
\hline Upstream of Effluent Line & W1 & 2 & $<\mathrm{MDC}$ & $<M D C$ & $<$ MDC & 100,000 & $<0.0001$ & $<0.0007$ & $<0.0004$ \\
\hline Downstream of Effluent Line & W3 & 2 & $<\mathrm{MDC}$ & $<M D C$ & $\angle M D C$ & 100,000 & $<0.0001$ & $<0.0023$ & $<0.0012$ \\
\hline Downstream of Effluent Line & W4 & 2 & $<M D C$ & $<M D C$ & $\angle M D C$ & 100,000 & $<0.0001$ & $<0.0015$ & $<0.0008$ \\
\hline
\end{tabular}


TABLE 13: Radionuclides in Surface Water, 1995

Page 2 of 2

\begin{tabular}{|c|c|c|c|c|c|c|c|c|c|}
\hline Parameter & $\begin{array}{l}\text { Sampling } \\
\text { Location(a) }\end{array}$ & $\begin{array}{c}\text { Number } \\
\text { of Samples }\end{array}$ & \multicolumn{3}{|c|}{ Concentration $(\mathrm{pCi} / \mathrm{L})^{(\mathrm{b})}$} & $\begin{array}{l}\text { Standards } \\
(\mathrm{pCi} / \mathrm{L})^{(\mathrm{c})}\end{array}$ & \multicolumn{3}{|c|}{ Percent of Standard } \\
\hline \multicolumn{10}{|l|}{ Paddys Run } \\
\hline \multicolumn{10}{|l|}{ Total Uranium } \\
\hline Upstream of the Site & W5 & 45 & 0.30 & 1.60 & 0.80 & 550 & 0.05 & 0.29 & 0.15 \\
\hline Onsite & W9 & 38 & 0.70 & 3.90 & 1.20 & 550 & 0.13 & 0.71 & 0.22 \\
\hline Onsite & W-10 US & 27 & 0.70 & 237 & 14.0 & 550 & 0.13 & 43.0 & 2.60 \\
\hline Onsite & W10 & 31 & 1.50 & 649 & 102 & 550 & 0.27 & 118 & 18.6 \\
\hline Onsite & W-10 DD & 41 & 68.0 & 1,080 & 438 & 550 & 12.4 & 197 & 79.6 \\
\hline Onsite & W-10 DS & 29 & 0.90 & 176 & 28.0 & 550 & 0.16 & 32.0 & 5.10 \\
\hline Onsite & W11 & 24 & 1.40 & 14.2 & 5.10 & 550 & 0.25 & 2.60 & 0.93 \\
\hline Downstream of the Site & W7 & 13 & 1.40 & 13.5 & 5.80 & 550 & 0.25 & 2.50 & 1.05 \\
\hline Downstream of the Site & W8 & 21 & 1.30 & 5.90 & 3.50 & 550 & 0.24 & 1.07 & 0.64 \\
\hline \multicolumn{10}{|l|}{ Radium-226(d) } \\
\hline Upstream of the Site & W5 & 6 & $<0.04$ & 0.08 & $<0.06$ & 100 & $<0.04$ & 0.08 & $<0.06$ \\
\hline Downstream of the Site & W7 & 7 & $<0.04$ & 0.07 & $<0.06$ & 100 & $<0.04$ & 0.07 & $<0.06$ \\
\hline Downstream of the Site & W8 & 3 & $<0.01$ & 0.12 & $<0.07$ & 100 & $<0.01$ & $<0.12$ & $<0.07$ \\
\hline \multicolumn{10}{|l|}{ Radium-228(d) } \\
\hline Upstream of the Site & W5 & 6 & $<1.20$ & 2.90 & $<2.00$ & 100 & $<1.20$ & 2.90 & $<2.00$ \\
\hline Downstream of the Site & W7 & 7 & $<2.90$ & 6.00 & $<3.90$ & 100 & $<2.90$ & 6.00 & $<3.90$ \\
\hline Downstream of the Site & W8 & 3 & $<0.10$ & $<0.10$ & $<0.10$ & 100 & $<0.10$ & $<0.10$ & $<0.01$ \\
\hline
\end{tabular}

(a) See Figure 35 on page 105 for sampling locations.

(b) To obtain Bq/L, multiply pCi/L by 0.037 .

(c) Standards as listed in DOE Order 5400.5, "Radiation Protection of the Public and Environment." The standards are based on drinking 730 liters (about 200 gallons) of water per year. The Fernald site compares data from the Great Miami River and Paddys Run to these standards even though neither is designated as a public water supply by OEPA (OEPA Regulations, Vol. 1, 3475-1-21).

(d) Samples are composited as follows:

- One-month composites of daily samples from W1 and W3,

- One-month composites of weekly samples from W4 and either W7 or W8,

- Two-month composites of weekly samples from W5, and

- Semiannual composites were used for those isotopes where two samples are recorded.

(e) $M D C=$ Minimum Detectable Concentration . 
TABLE 14: Radionuclides in Great Miami River, Paddys Run, and Storm Sewer Outfall Ditch Sediments, 1995(a)

\begin{tabular}{|l|l|l|l|}
\hline Radionuclide & $\begin{array}{l}\text { Number of } \\
\text { Samples }(e)\end{array}$ & $\begin{array}{l}\text { Concentration (pci/g dry) } \\
\text { Minimum }\end{array}$ & $\begin{array}{c}\text { Average for } \\
\text { Maximum }\end{array}$
\end{tabular}

Great Miami River North of the Effluent Line (d),(e)

\begin{tabular}{|l|c|c|c|c|}
\hline Total Uranium & 3 & $0.95 \pm 0.03$ & $1.22 \pm 0.04$ & $1.08 \pm 0.03$ \\
\hline
\end{tabular}

Great Miami River South of the Effluent Line (d)

\begin{tabular}{|l|c|c|c|c|c|c|}
\hline Total Uranium & 3 & $0.74 \pm 0.07$ & $1.70 \pm 0.05$ & $1.29 \pm 0.04$ \\
\hline
\end{tabular}
Paddys Run Background (North of S.R. 126) (e)
\begin{tabular}{|l|c|c|c|c|c|c|}
\hline Radium-226 & 5 & $0.48 \pm 0.07$ & $1.00 \pm 0.11$ & $0.77 \pm 0.03$ \\
\hline Thorium-228 & 5 & $0.39 \pm 0.10$ & $1.10 \pm 0.16$ & $0.75 \pm 0.06$ \\
\hline Thorium-230 & 5 & $0.39 \pm 0.10$ & $1.00 \pm 0.15$ & $0.71 \pm 0.04$ \\
\hline Thorium-232 & 5 & $0.26 \pm 0.07$ & $0.98 \pm 0.14$ & $0.60 \pm 0.06$ \\
\hline Total Uranium & 5 & $0.68 \pm 0.02$ & $1.69 \pm 0.05$ & $1.23 \pm 0.02$ \\
\hline
\end{tabular}

Paddys Run North of the Storm Sewer Outfall Ditch (d),(e)

\begin{tabular}{|l|c|c|c|c|c|}
\hline Radium-226 & 13 & $0.39 \pm 0.04$ & $0.79 \pm 0.14$ & $0.53 \pm 0.09$ \\
\hline Thorium-228 & 13 & $0.27 \pm 0.07$ & $0.53 \pm 0.16$ & $0.39 \pm 0.08$ \\
\hline Thorium-230 & 13 & $0.39 \pm 0 . .09$ & $0.79 \pm 0.22$ & $0.55 \pm 0.12$ \\
\hline Thorium-232 & 13 & $0.26 \pm 0.06$ & $0.47 \pm 0.16$ & $0.36 \pm 0.09$ \\
\hline Total Uranium & 13 & $0.63 \pm 0.02$ & $2.23 \pm 0.07$ & $1.09 \pm 0.05$ \\
\hline
\end{tabular}

Storm Sewer Outfall Ditch (e)

\begin{tabular}{|l|c|c|c|c|c|}
\hline Radium-226 & 9 & $0.42 \pm 0.05$ & $1.10 \pm 0.12$ & $0.69 \pm 0.07$ \\
\hline Thorium-228 & 9 & $0.40 \pm 0.10$ & $1.30 \pm 0.17$ & $0.69 \pm 0.07$ \\
\hline Thorium-230 & 9 & $0.51 \pm 0.11$ & $1.90 \pm 0.21$ & $0.87 \pm 0.09$ \\
\hline Thorium-232 & 9 & $0.27 \pm 0.07$ & $1.00 \pm 0.13$ & $0.52 \pm 0.06$ \\
\hline Total Uranium & 9 & $1.49 \pm 0.05$ & $15.54 \pm 1.15$ & $5.55 \pm 1.20$ \\
\hline
\end{tabular}

Paddys Run South of Storm Sewer Outfall Ditch (d),(e)

\begin{tabular}{|l|c|c|c|c|c|}
\hline Total Uranium & 6 & $0.68 \pm 0.03$ & $6.62 \pm 0.20$ & $2.69 \pm 0.15$ \\
\hline
\end{tabular}

(a) See Figure 35 on page 105 for sampling locations.

(b) Multiply pCi/g by 0.037 to obtain $\mathrm{Bq} / \mathrm{g}$.

(c) The plus/minus $( \pm)$ values are the uncertainty in the analytical results at the $95 \%$ confidence level.

(d) Includes OEPA split samples.

(e) Includes QA samples. 
TABLE 15: Uranium Concentrations in Fish from the Great Miami River, 1995

\begin{tabular}{|c|c|c|c|c|c|}
\hline \multirow{2}{*}{$\begin{array}{l}\text { Sampling } \\
\text { Location(a) }\end{array}$} & \multirow{2}{*}{ Family $^{(b)}$} & \multirow{2}{*}{$\begin{array}{c}\text { Number } \\
\text { of Samples }\end{array}$} & \multicolumn{3}{|c|}{ Concentration $\mathrm{pCi} / \mathrm{g}(\mathrm{c})$} \\
\hline & & & Minimum & Maximum & Geometric Mean \\
\hline \multirow{10}{*}{$\begin{array}{l}\text { RM } 38 \\
\text { Upstream of } \\
\text { the Hamilton Dam }\end{array}$} & 1 & 8 & 0.0030 & 0.0173 & 0.0062 \\
\hline & 2 & 7 & 0.0030 & 0.0095 & 0.0170 \\
\hline & 3 & 2 & 0.0105 & 0.0269 & 0.0168 \\
\hline & 4 & 2 & 0.0028 & 0.0085 & 0.0049 \\
\hline & 5 & 5 & 0.0014 & 0.0045 & 0.0029 \\
\hline & 6 & 0 & $N / A$ & N/A & $N / A$ \\
\hline & 7 & 0 & N/A & N/A & $N / A$ \\
\hline & 8 & 0 & N/A & $N / A$ & N/A \\
\hline & 9 & 0 & $\mathrm{~N} / \mathrm{A}$ & $N / A$ & N/A \\
\hline & $\begin{array}{l}\text { Location } \\
\text { Summary }\end{array}$ & 24 & 0.0014 & 0.0269 & 0.0057 \\
\hline \multirow{10}{*}{$\begin{array}{l}\text { RM } 24 \\
\text { At the Effluent } \\
\text { Line }\end{array}$} & 1 & 5 & 0.0021 & 0.0089 & 0.0040 \\
\hline & 2 & 7 & 0.0009 & 0.0114 & 0.0038 \\
\hline & 3 & 2 & 0.0146 & 0.0178 & 0.0161 \\
\hline & 4 & 2 & 0.0036 & 0.0049 & 0.0042 \\
\hline & 5 & 5 & 0.0001 & 0.0052 & 0.0014 \\
\hline & 6 & 2 & 0.0047 & 0.0594 & 0.0167 \\
\hline & 7 & 0 & $\mathrm{~N} / \mathrm{A}$ & N/A & $N / A$ \\
\hline & 8 & 0 & N/A & $N / A$ & N/A \\
\hline & 9 & 3 & 0.0014 & 0.0021 & 0.0016 \\
\hline & $\begin{array}{l}\text { Location } \\
\text { Summary }\end{array}$ & 26 & 0.0009 & 0.0594 & 0.0036 \\
\hline \multirow{10}{*}{$\begin{array}{l}\text { RM } 19 \\
\text { At confluence of } \\
\text { Paddys Run and } \\
\text { the Great Miami } \\
\text { River }\end{array}$} & 1 & 2 & 0.0029 & 0.0055 & 0.0040 \\
\hline & 2 & 5 & 0.0002 & 0.0092 & 0.0019 \\
\hline & 3 & 2 & 0.0038 & 0.0056 & 0.0046 \\
\hline & 4 & 3 & 0.0025 & 0.0050 & 0.0034 \\
\hline & 5 & 2 & 0.0003 & 0.0012 & 0.0006 \\
\hline & 6 & 0 & N/A & N/A & N/A \\
\hline & 7 & 3 & 0.0023 & 0.0048 & 0.0036 \\
\hline & 8 & 2 & 0.0010 & 0.0021 & 0.0015 \\
\hline & 9 & 3 & 0.0008 & 0.0052 & 0.0019 \\
\hline & $\begin{array}{l}\text { Location } \\
\text { Summary }\end{array}$ & 22 & 0.0002 & 0.0092 & 0.0023 \\
\hline
\end{tabular}

(a) See Figure 38 on page 110 for sampling locations.

(b) Family:

$1=$ Cyprinidae (carp and shiner)

2 = Catostomidae (carpsucker, redhorse, quillback, and buffalo)

3 = Clupeidae (gizzard shad)

4 = Centrarchidae (bludgill, sunfish, smallmouth and largemouth bass)

$5=$ Ictaluridae (yellow bullhead and catfish)

$6=$ Lepisosteidae (longnose gar)

$7=$ Percicthyidae (white bass)

8 = Percidae (logperch and sauger)

9 = Scianidae (fresh water drum)

(c) All concentrations are reported in dry weight. Multiply by 0.037 to obtain Bq/g (dry weight) 
TABLE 16A: NPDES Noncompliance Summary, 1995

\begin{tabular}{|c|c|c|c|c|c|}
\hline Source & Number & Date & Parameter & Permit Limit & Incident Measure \\
\hline \multirow[t]{29}{*}{ Manhole 175-4001 } & 95-01 & 5-18-95 & $\mathrm{ph}(\mathrm{MAX})$ & $9.0 ; 1 \mathrm{hr} .0 \mathrm{~min}$. & $1 ; 1 \mathrm{hr} .2 \mathrm{~min}$. \\
\hline & $95-02$ & 5-19-95 & $\mathrm{ph}(\mathrm{MAX})$ & $9.0 ; 1$ hr. 0 min. & $1 ; 8$ hrs. \\
\hline & $95-03$ & $5-20-95$ & $\mathrm{ph}(\mathrm{MAX})$ & $9.0 ; 1$ hr. 0 min. & 1; 3 hrs. \\
\hline & $95-04$ & $5-21-95$ & $\mathrm{ph}(\mathrm{MAX})$ & $9.0 ; 1 \mathrm{hr} .0 \mathrm{~min}$. & 1; 3 hrs. \\
\hline & $95-05$ & 5-22-95 & $\mathrm{ph}(\mathrm{MAX})$ & $9.0 ; 1$ hr. 0 min. & $9 ; 1$ hr. 3 min. \\
\hline & $95-06$ & 5-22-95 & $\mathrm{ph}(\mathrm{MAX})$ & $9.0 ; 1 \mathrm{hr} .0 \mathrm{~min}$. & 1; 4 hrs. \\
\hline & $95-07$ & $5-22-95$ & $\mathrm{ph}(\mathrm{MAX})$ & $9.0 ; 1$ hr. 0 min. & 1; 3 hrs. \\
\hline & $95-08$ & $5-24-95$ & ph (MAX) & $9.0 ; 1$ hr. 0 min. & 1; 3 hrs. \\
\hline & $95-09$ & 5-24-95 & $\mathrm{ph}(\mathrm{MAX})$ & $9.0 ; 1$ hr. 0 min. & 9; 3 hrs. \\
\hline & $95-10$ & 5-24-95 & ph (MAX) & $9.0 ; 1 \mathrm{hr} .0 \mathrm{~min}$. & 1; 3 hrs. \\
\hline & $95-11$ & $5-25-95$ & $\mathrm{ph}(\mathrm{MAX})$ & 9.0; 1 hr. 0 min. & $1 ; 5$ hrs. \\
\hline & $95-12$ & 5-25-95 & ph (MAX) & $9.0 ; 1 \mathrm{hr} .0 \mathrm{~min}$. & $1 ; 6$ hrs. \\
\hline & $95-13$ & $5-25-95$ & ph (MAX) & $9.0 ; 1$ hr. 0 min. & $1 ; 2$ hrs. \\
\hline & $95-14$ & $5-25-95$ & ph (MAX) & $9.0 ; 1 \mathrm{hr} .0 \mathrm{~min}$. & 1; 2 hrs. \\
\hline & $95-15$ & $5-26-95$ & $\mathrm{ph}(\mathrm{MAX})$ & $9.0 ; 1 \mathrm{hr} .0 \mathrm{~min}$. & $1 ; 3$ hrs. \\
\hline & $95-16$ & 5-26-95 & $\mathrm{ph}(\mathrm{MAX})$ & $9.0 ; 1 \mathrm{hr} .0 \mathrm{~min}$. & 9; 2 hrs. \\
\hline & $95-17$ & $5-27-95$ & $\mathrm{ph}(\mathrm{MAX})$ & $9.0 ; 1 \mathrm{hr} .0 \mathrm{~min}$. & 1; 6 hrs. \\
\hline & $95-18$ & 5-27-95 & ph (MAX) & $9.0 ; 1 \mathrm{hr} .0 \mathrm{~min}$. & 1; 4 hrs. \\
\hline & $95-19$ & $5-28-95$ & $\mathrm{ph}(\mathrm{MAX})$ & $9.0 ; 1 \mathrm{hr} .0 \mathrm{~min}$. & $1 ; 1 \mathrm{hr} .2 \mathrm{~min}$. \\
\hline & $95-20$ & $5-28-95$ & $\mathrm{ph}(\mathrm{MAX})$ & $9.0 ; 1 \mathrm{hr} .0 \mathrm{~min}$. & $1 ; 2$ hrs. \\
\hline & $95-21$ & $5-28-95$ & ph (MAX) & $9.0 ; 1 \mathrm{hr} .0 \mathrm{~min}$. & 9; 1 hr. $4 \mathrm{~min}$. \\
\hline & $95-22$ & $5-29-95$ & $\mathrm{ph}(\mathrm{MAX})$ & $9.0 ; 1$ hr. 0 min. & 9; $1 \mathrm{hr} .4 \mathrm{~min}$. \\
\hline & $95-23$ & $5-29-95$ & $\mathrm{ph}(\mathrm{MAX})$ & $9.0 ; 1 \mathrm{hr} .0 \mathrm{~min}$. & 9; $1 \mathrm{hr} .0 \mathrm{~min}$. \\
\hline & $95-24$ & $5-30-95$ & $\mathrm{ph}(\mathrm{MAX})$ & $9.0 ; 1$ hr. 0 min. & 9; 1 hr. 5 min. \\
\hline & $95-25$ & $5-30-95$ & ph (MAX) & $9.0 ; 1 \mathrm{hr} .0 \mathrm{~min}$. & $9 ; 1 \mathrm{hr}$. \\
\hline & $95-26$ & $5-30-95$ & $\mathrm{ph}(\mathrm{MAX})$ & $9.0 ; 1 \mathrm{hr} .0 \mathrm{~min}$. & $9 ; 2$ hr. 5 min. \\
\hline & $95-27$ & $5-31-95$ & $\mathrm{ph}(\mathrm{MAX})$ & $9.0 ; 1$ hr. 0 min. & $1 ; 4 \mathrm{hr}$. \\
\hline & $95-28$ & $5-31-95$ & $\mathrm{ph}(\mathrm{MAX})$ & $9.0 ; 1 \mathrm{hr} .0 \mathrm{~min}$. & $9 ; 2$ hr. \\
\hline & $95-29$ & $5-95$ & ph & $7 \mathrm{hr} .26 \mathrm{~min}$. & 94 hrs. \\
\hline \multirow{2}{*}{$\begin{array}{l}\text { Sewage Treatment } \\
\text { Plant-4601 }\end{array}$} & $95-30$ & 5-3-95 & Fecal Coliform & 2,000;\#/100ML & $3 ; \# / 1$ \\
\hline & $95-31$ & $5-9-95$ & Fecal Coliform & 2,$000 ; \# / 100 \mathrm{ML}$ & $2 ; \# / 1$ \\
\hline \multirow{6}{*}{$\begin{array}{l}\text { Biodenitrification } \\
\text { Effluent-4605 }\end{array}$} & $95-32$ & $7-5-95$ & TSS & $45 \mathrm{mg} / \mathrm{L}$ (daily maximum) & 61 \\
\hline & $95-33$ & $10-10-95$ & $\mathrm{BOD}$ & 45 mg/L (daily maximum) & 147 \\
\hline & $95-34$ & $10-95$ & BOD & 38 kg/d (daily maximum) & 71.2 \\
\hline & $95-35$ & $10-95$ & BOD & $30 \mathrm{mg} / \mathrm{L}$ (monthly average) & 82.2 \\
\hline & $95-36$ & $10-95$ & BOD & $26 \mathrm{~kg} / \mathrm{d}$ (monthly average) & 40.0 \\
\hline & $95-37$ & $10-95$ & Nitrate-Nitrogen & $72.7 \mathrm{mg} / \mathrm{L}$ (monthly average) & 81.1 \\
\hline
\end{tabular}


TABLE 16B: Gross Alpha Data Greater than or Equal to Proposed Drinking Water Standards, 1995

\begin{tabular}{|l|l|c|c|}
\hline Well & \multicolumn{1}{|c|}{ Location } & Sample Date & $\begin{array}{c}\text { Concentration } \\
\text { (pCi/L) }\end{array}$ \\
\hline & Gross Alpha (a) & & \\
\hline 2015 & South Plume, onsite & $2-15-95$ & 92 \\
\hline 2060 & South Plume, offsite & $2-17-95$ & 37 \\
\hline 2106 & South Plume, onsite & $9-11-95$ & 18.464 \\
\hline 2106 & South Plume, onsite & $9-11-95$ & 21.407 \\
\hline 2106 & South Plume, onsite & $4-10-95$ & 26 \\
\hline 2106 & South Plume, onsite & $1-17-95$ & 28.15 \\
\hline 2430 & East Field & $7-12-95$ & 16.935 \\
\hline 2550 & South Plume, offsite & $2-16-95$ & 56 \\
\hline 2552 & South Plume, offsite & $2-28-95$ & 15 \\
\hline 2754 & East Field & $9-6-95$ & 16.828 \\
\hline 2754 & East Field & $7-11-95$ & 26 \\
\hline 2754 & East Field & $1-10-95$ & 26.403 \\
\hline 3069 & South Plume, onsite & $4-4-95$ & 40 \\
\hline 3069 & South Plume, onsite & $4-4-95$ & 41 \\
\hline 3069 & South Plume, onsite & $1-10-95$ & 46.128 \\
\hline 3069 & South Plume, onsite & $9-12-95$ & 55.372 \\
\hline 3069 & South Plume, onsite & $7-19-95$ & 56.025 \\
\hline 3733 & East Field & $1-9-95$ & 22 \\
\hline
\end{tabular}

(a) Proposed USEPA standard for gross alpha is $15 \mathrm{pCi} / \mathrm{L}$. 
Table 17: Uranium in Private Wells, 1995

\begin{tabular}{|c|c|c|c|c|c|c|c|}
\hline \multirow{2}{*}{$\begin{array}{c}\text { Well } \\
\text { Number (a) }\end{array}$} & \multirow{2}{*}{$\begin{array}{c}\text { Number } \\
\text { of Samples }\end{array}$} & \multicolumn{3}{|c|}{ Concentration $(\mathrm{pCi} / \mathrm{L})(\mathrm{b})$} & \multicolumn{3}{|c|}{ Percent of Standard (c) } \\
\hline & & Minimum & Maximum & Average & Minimum & Maximum & Average \\
\hline 3 & 10 & $<\quad 0.1$ & $<\quad 0.1$ & $<\quad 0.1$ & $<\quad 0.5$ & $<\quad 0.5$ & $<\quad 0.5$ \\
\hline 4 & 11 & 0.9 & 1.7 & 1.2 & 6.5 & 12.5 & 8.8 \\
\hline 8 & 12 & 0.5 & 0.9 & 0.6 & 4.0 & 6.5 & 4.7 \\
\hline 9 & 12 & 0.9 & 1.1 & 1.0 & 6.5 & 8.5 & 7.3 \\
\hline 10 & 11 & 0.3 & 0.4 & 0.4 & 2.0 & 3.0 & 2.6 \\
\hline 11 & 12 & 0.9 & 1.4 & 1.2 & 7.0 & 10.5 & 8.6 \\
\hline $12(d)$ & 11 & 28 & 122 & 58 & 205 & 901 & 433 \\
\hline 13 (d) & 9 & 5.0 & 64 & 49 & 37 & 470 & 361 \\
\hline 14 & 14 & 1.4 & 1.8 & 1.5 & 10.0 & 13.5 & 11.4 \\
\hline $15(d)$ & 12 & 108 & 122 & 113 & 801 & 901 & 834 \\
\hline 16 & 12 & 0.5 & 0.8 & 0.6 & 3.5 & 6.0 & 4.7 \\
\hline 18 & 12 & 0.3 & 0.4 & 0.3 & 2.0 & 3.0 & 2.5 \\
\hline 19 & 10 & 0.1 & 2.0 & 0.3 & 0.5 & 15.0 & 2.0 \\
\hline 21 & 11 & 0.2 & 0.3 & 0.3 & 1.5 & 2.5 & 2.0 \\
\hline 22 & 12 & 0.7 & 1.4 & 0.8 & 5.0 & 10.5 & 5.9 \\
\hline 23 & 12 & 0.3 & 0.7 & 0.5 & 2.5 & 5.0 & 4.0 \\
\hline 24 & 11 & 0.3 & 0.8 & 0.4 & 2.0 & 6.0 & 2.8 \\
\hline 25 & 5 & 0.2 & 0.4 & 0.3 & 1.5 & 3.0 & 1.9 \\
\hline 26 & 10 & 0.1 & 0.3 & 0.1 & 0.5 & 2.5 & 0.8 \\
\hline 28 & 5 & 0.3 & 0.6 & 0.5 & 2.5 & 4.5 & 3.9 \\
\hline 29 & 12 & 1.2 & 1.5 & 1.4 & 9.0 & 11.0 & 10.1 \\
\hline 30 & 5 & 0.4 & 0.5 & 0.5 & 3.0 & 4.0 & 3.4 \\
\hline 32 & 12 & 0.1 & 0.1 & 0.1 & 0.5 & 0.5 & 0.5 \\
\hline 33 & 12 & 0.3 & 0.4 & 0.4 & 2.5 & 3.0 & 2.6 \\
\hline 34 & 12 & 1.0 & 7.4 & $2.7^{\circ}$ & 7.5 & 55 & 20 \\
\hline 35 & 10 & 1.1 & 1.4 & 1.3 & 8.5 & 10.5 & 9.3 \\
\hline 36 & 12 & 0.6 & 0.9 & 0.8 & 4.5 & 6.5 & 5.8 \\
\hline 37 & 1 & 0.9 & 0.9 & 0.9 & 7.0 & 7.0 & 7.0 \\
\hline $38(\mathrm{e})$ & 5 & 0.1 & 0.1 & 0.1 & 0.5 & 1.0 & 0.6 \\
\hline 39 (d) & 10 & 2.8 & 5.1 & 4.3 & 21 & 38 & 32 \\
\hline 40 (d) & 12 & 1.8 & 3.2 & 2.2 & 14 & 24 & 16 \\
\hline 41 & 12 & 0.3 & 0.4 & 0.3 & 2.5 & 3.0 & 2.5 \\
\hline 55 & 3 & 0.3 & 0.3 & 0.3 & 2.0 & 2.5 & 2.3 \\
\hline
\end{tabular}

NOTE: Column headers were incorrectly titled on original table and some values were incorrectly reported.

(a) See Figure 42 on page 121 for well locations. Wells are numbered in order of first time sampled.

(b) To obtain Bq/L, multiply pCi/L by 0.037 .

(c) Proposed USEPA standard of $13.5 \mathrm{pCi} / \mathrm{L}(20 \mathrm{ppb})$.

(d) These wells are used for monitoring purposes only.

(e) Sample collected from a cistern. 
$x-1$ 
TABLE 17: Uranium in Private Wells, 1995

\begin{tabular}{|c|c|c|c|c|c|c|c|}
\hline \multirow{2}{*}{$\begin{array}{c}\text { Well } \\
\text { Number(a) }\end{array}$} & \multirow{2}{*}{$\begin{array}{c}\text { Number } \\
\text { of Samples }\end{array}$} & \multicolumn{3}{|c|}{ Concentration $(\mathrm{pCi} / \mathrm{L})^{(\mathrm{b})}$} & \multicolumn{3}{|c|}{ Percent of Standard $(c)$} \\
\hline & & Minimum & Maximum & Average & Minimum & Maximum & Average \\
\hline 3 & 10 & $<0.1$ & $<0.1$ & $<0.1$ & $<0.5$ & $<0.5$ & $<0.5$ \\
\hline 4 & 11 & 0.9 & 1.2 & 1.7 & 9.1 & 6.8 & 13.0 \\
\hline 8 & 12 & 0.5 & 0.6 & 0.9 & 4.9 & 4.2 & 6.8 \\
\hline 9 & 12 & 0.9 & 1.0 & 1.1 & 7.6 & 6.8 & 8.8 \\
\hline 10 & 11 & 0.3 & 0.4 & 0.4 & 2.7 & 2.1 & 3.1 \\
\hline 11 & 12 & 0.9 & 1.2 & 1.4 & 9.0 & 7.3 & 10.9 \\
\hline $12^{(d)}$ & 11 & 27.7 & 58.4 & 121.6 & 449.4 & 213.1 & 935.6 \\
\hline $13^{(d)}$ & 9 & 5.0 & 48.8 & 63.5 & 375.0 & 38.5 & 488.6 \\
\hline 14 & 14 & 1.4 & 1.5 & 1.8 & 11.9 & 10.4 & 14.0 \\
\hline $15^{(d)}$ & 12 & 108.1 & 112.6 & 121.6 & 866.3 & 831.6 & 935.6 \\
\hline 16 & 12 & 0.5 & 0.6 & 0.8 & 4.9 & 3.6 & 6.2 \\
\hline 18 & 12 & 0.3 & 0.3 & 0.4 & 2.6 & 2.1 & 3.1 \\
\hline 19 & 10 & $<0.1$ & $<0.3$ & 2.0 & $<2.0$ & $<0.5$ & 15.6 \\
\hline 21 & 11 & 0.2 & 0.3 & 0.3 & 2.1 & 1.6 & 2.6 \\
\hline 22 & 12 & 0.7 & 0.8 & 1.4 & 6.2 & 5.2 & 10.9 \\
\hline 23 & 12 & 0.3 & 0.5 & 0.7 & 4.2 & 2.6 & 5.2 \\
\hline 24 & 11 & 0.3 & 0.4 & 0.8 & 2.9 & 2.1 & 6.2 \\
\hline 25 & 5 & 0.2 & 0.3 & 0.4 & 2.0 & 1.6 & 3.1 \\
\hline 26 & 10 & 0.1 & 0.1 & 0.3 & 0.8 & 0.5 & 2.6 \\
\hline 28 & 5 & 0.3 & 0.5 & 0.6 & 4.1 & 2.6 & 4.7 \\
\hline 29 & 12 & 1.2 & 1.4 & 1.5 & 10.4 & 9.4 & 11.4 \\
\hline 30 & 5 & 0.4 & 0.5 & 0.5 & 3.5 & 3.1 & 4.2 \\
\hline 32 & 12 & $<0.1$ & $<0.1$ & 0.1 & $<0.5$ & $<0.5$ & 0.5 \\
\hline 33 & 12 & 0.3 & 0.4 & 0.4 & 2.7 & 2.6 & 3.1 \\
\hline 34 & 12 & 1.0 & 2.7 & 7.4 & 21.1 & 7.8 & 57.2 \\
\hline 35 & 10 & 1.1 & 1.3 & 1.4 & 9.6 & 8.8 & 10.9 \\
\hline 36 & 12 & 0.6 & 0.8 & 0.9 & 6.0 & 4.7 & 6.8 \\
\hline 37 & 1 & 0.9 & 0.9 & 0.9 & 7.3 & 7.3 & 7.3 \\
\hline $38(e)$ & 5 & $<0.1$ & $<0.1$ & 0.1 & $<0.6$ & $<0.6$ & 1.0 \\
\hline 39 (d) & 10 & 2.8 & 4.3 & 5.1 & 33.0 & 21.3 & 39.0 \\
\hline $40^{(d)}$ & 12 & 1.8 & 2.2 & 3.2 & 16.7 & 14.0 & 24.9 \\
\hline 41 & 12 & 0.3 & 0.3 & 0.4 & 2.6 & 2.6 & 3.1 \\
\hline 55 & 3 & 0.3 & 0.3 & 0.3 & 2.4 & 2.1 & 2.6 \\
\hline
\end{tabular}

(a) See Figure 42 on page 121 for well locations. Wells are numbered in order of first time sampled.

(b) To obtain Bq/L, multiply $\mathrm{pCi} / \mathrm{L}$ by 0.037 .

(c) Proposed USEPA standard of 13.5 $\mathrm{pCi} / \mathrm{L}(20 \mathrm{ppb})$.

(d) These wells are used for monitoring purposes only.

(e) Sample collected from a cistern. 
TABLE 18: Summary Statistics and Trend Analysis for Routine Monitoring Program Wells Constituent Concentrations Above Final Remediation Levels, 1988-1995 Data

\begin{tabular}{|c|c|c|c|c|c|c|c|c|c|}
\hline Constituent (FRL) & Well & Location & $\begin{array}{l}\text { Number of } \\
\text { Samples }(a)\end{array}$ & $\begin{array}{l}\text { Number of } \\
\text { Samples } \\
\text { Above FRL }\end{array}$ & $\begin{array}{l}\text { Minimum } \\
(\mathrm{mg} / \mathrm{L})(\mathrm{b}, \mathrm{c})\end{array}$ & $\begin{array}{l}\text { Maximum } \\
(\mathrm{mg} / \mathrm{L})\end{array}$ & Mean (mg/L) & $\begin{array}{c}\text { Standard } \\
\text { Deviation } \\
\text { (mg/L) }\end{array}$ & Trend $(e)$ \\
\hline \multirow[t]{24}{*}{ Fluoride (0.89 mg/L) } & 2424 & 2 & 10 & 4 & 0.25 & 1.6 & 0.788 & 0.576 & No Trend \\
\hline & 3424 & 2 & 9 & 4 & 0.4 & 1.8 & 0.954 & 0.588 & No Trend \\
\hline & 4424 & 2 & 9 & 4 & 0.3 & 1.9 & 0.904 & 0.654 & No Trend \\
\hline & 2051 & 3 & 25 & 5 & 0.15 & 1.2 & 0.425 & 0.334 & No Trend \\
\hline & 31217 & 3 & 9 & 4 & 0.16 & 1.7 & 0.771 & 0.657 & No Trend \\
\hline & 41217 & 3 & 9 & 4 & 0.33 & 2 & 1.14 & 0.753 & No Trend \\
\hline & 2426 & 4 & 10 & 4 & 0.045 & 1.5 & 0.652 & 0.596 & No Trend \\
\hline & 3426 & 4 & 9 & 4 & 0.24 & 1.1 & 0.601 & 0.384 & No Trend \\
\hline & 4426 & 4 & 10 & 4 & 0.26 & 1.9 & 0.939 & 0.707 & No Trend \\
\hline & 2417 & 5 & 13 & 3 & 0.055 & 1.3 & 0.451 & 0.455 & No Trend \\
\hline & 3417 & 5 & 9 & 1 & 0.065 & 0.9 & 0.454 & 0.335 & No Trend \\
\hline & 2429 & 6 & 10 & 3 & 0.14 & 1.2 & 0.514 & 0.435 & No Trend \\
\hline & 3429 & 6 & 9 & 1 & 0.09 & 0.9 & 0.337 & 0.270 & No Trend \\
\hline & 2430 & 7 & 11 & 6 & 0.12 & 1.6 & 0.618 & 0.604 & No Trend \\
\hline & 4067 & 7 & 13 & 3 & 0.21 & 0.95 & 0.441 & 0.284 & No Trend \\
\hline & 2431 & 8 & 9 & 3 & 0.11 & 1 & 0.468 & 0.392 & No Trend \\
\hline & 2432 & 9 & 10 & 4 & 0.125 & 1.2 & 0.498 & 0.418 & No Trend \\
\hline & 3432 & 9 & 9 & 2 & 0.1 & 1 & 0.444 & 0.352 & No Trend \\
\hline & 2733 & 10 & 10 & 4 & 0.055 & 1.2 & 0.462 & 0.396 & No Trend \\
\hline & 2398 & 12 & 14 & 2 & 0.05 & 0.9 & 0.342 & 0.341 & No Trend \\
\hline & 3398 & 12 & 11 & 1 & 0.11 & 0.9 & 0.384 & 0.334 & No Trend \\
\hline & 4398 & 12 & 10 & 1 & 0.12 & 0.85 & 0.406 & 0.333 & No Trend \\
\hline & 2434 & 13 & 11 & 2 & 0.065 & 1 & 0.420 & 0.343 & No Trend \\
\hline & 3106 & 14 & 19 & 1 & 0.075 & 0.9 & 0.268 & 0.254 & No Trend \\
\hline
\end{tabular}


TABLE 18: Summary Statistics and Trend Analysis for Routine Monitoring Program Wells Constituent Concentrations Above Final Remediation Levels, 1988-1995 Data

\begin{tabular}{|c|c|c|c|c|c|c|c|c|c|}
\hline Constituent (FRL) & Well & Location & $\begin{array}{l}\text { Number of } \\
\text { Samples (a) }\end{array}$ & $\begin{array}{l}\text { Number of } \\
\text { Samples } \\
\text { Above FRL }\end{array}$ & $\begin{array}{l}\text { Minimum } \\
(\mathrm{mg} / \mathrm{L})(\mathrm{b}, \mathrm{c})\end{array}$ & $\begin{array}{l}\text { Maximum } \\
(\mathrm{mg} / \mathrm{L})\end{array}$ & Mean (mg/L) & $\begin{array}{c}\text { Standard } \\
\text { Deviation } \\
\text { (mg/L) }\end{array}$ & Trend $(e)$ \\
\hline \multirow[t]{6}{*}{ Antimony $(0.006 \mathrm{mg} / \mathrm{L})$} & 2424 & 2 & 11 & 1 & 0.0015 & 0.0304 & 0.0154 & 0.0091 & No Trend \\
\hline & 41217 & 3 & 9 & 1 & 0.0015 & 0.0357 & 0.0175 & 0.0106 & No Trend \\
\hline & 4426 & 4 & 12 & 1 & 0.0015 & 0.0318 & 0.0151 & 0.0099 & No Trend \\
\hline & 3417 & 5 & 9 & 1 & 0.0015 & 0.0392 & 0.0181 & 0.0112 & Down, Marginal \\
\hline & 2432 & 9 & 10 & 1 & 0.0015 & 0.0304 & 0.0168 & 0.0088 & No Trend \\
\hline & 3070 & 11 & 12 & 1 & 0.0015 & 0.0304 & 0.0160 & 0.0079 & No Trend \\
\hline \multirow[t]{3}{*}{ Cadmium (0.14 mg/L) } & 2424 & 2 & 11 & 1 & 0.001 & 0.016 & 0.003 & 0.004 & Down, Sig. \\
\hline & 2417 & 5 & 11 & 1 & 0.001 & 0.016 & 0.003 & 0.004 & Down, Sig. \\
\hline & 2733 & 10 & 10 & 1 & 0.001 & 0.019 & 0.004 & 0.005 & Down, Sig. \\
\hline \multirow[t]{13}{*}{ Lead (0.002 mg/L) } & 2424 & 2 & 11 & 1 & 0.00035 & 0.0027 & 0.0011 & 0.0006 & No Trend \\
\hline & 4424 & 2 & 9 & 1 & 0.00035 & 0.013 & 0.0022 & 0.0038 & No Trend \\
\hline & 31217 & 3 & 9 & 1 & 0.00035 & 0.02 & 0.0030 & 0.0060 & No Trend \\
\hline & 41217 & 3 & 9 & 2 & 0.00045 & 0.0043 & 0.0017 & 0.0014 & No Trend \\
\hline & 2426 & 4 & 10 & 2 & 0.00035 & 0.0023 & 0.0014 & 0.0007 & Down, Sig. \\
\hline & 2417 & 5 & 11 & 1 & 0.00035 & 0.003 & 0.0011 & 0.0007 & No Trend \\
\hline & 3429 & 6 & 9 & 1 & 0.0005 & 0.0028 & 0.0011 & 0.0007 & No Trend \\
\hline & 2430 & 7 & 12 & 1 & 0.00035 & 0.0016 & 0.0007 & 0.0004 & No Trend \\
\hline & 2431 & 8 & 9 & 1 & 0.00035 & 0.0022 & 0.0009 & 0.0006 & No Trend \\
\hline & 2733 & 10 & 10 & 1 & 0.00035 & 0.0243 & 0.0032 & 0.0070 & No Trend \\
\hline & 2070 & 111 & 12 & 5 & 0.00045 & 0.00492 & 0.0017 & 0.0014 & No Trend \\
\hline & 3070 & 11 & 12 & 2 & 0.00035 & 0.0047 & 0.0013 & 0.0012 & Down, Marginal \\
\hline & 2398 & 12 & 10 & 1 & 0.0005 & 0.0026 & 0.0010 & 0.0006 & No Trend \\
\hline
\end{tabular}


TABLE 18: Summary Statistics and Trend Analysis for Routine Monitoring Program Wells Constituent Concentrations Above Final Remediation Levels, 1988-1995 Data

\begin{tabular}{|c|c|c|c|c|c|c|c|c|c|}
\hline Constituent (FRL) & Well & Location & $\begin{array}{l}\text { Number of } \\
\text { Samples (a) }\end{array}$ & $\begin{array}{l}\text { Number of } \\
\text { Samples } \\
\text { Above FRL }\end{array}$ & $\begin{array}{l}\text { Minimum } \\
(\mathrm{mg} / \mathrm{L}) \\
(\mathrm{b}, \mathrm{c})\end{array}$ & $\begin{array}{l}\text { Maximum } \\
(\mathrm{mg} / \mathrm{L})\end{array}$ & Mean (mg/L) & $\begin{array}{c}\text { Standard } \\
\text { Deviation } \\
\text { (mg/L) }\end{array}$ & Trend $(e)$ \\
\hline \multirow[t]{2}{*}{ Manganese $(0.90 \mathrm{mg} / \mathrm{L})$} & 2424 & 2 & 11 & 1 & 0.016 & 0.935 & 0.392 & 0.231 & Up, Sig. \\
\hline & 2733 & 10 & 10 & 1 & 0.006 & 1.13 & 0.288 & 0.356 & No Trend \\
\hline Nickel $(0.10 \mathrm{mg} / \mathrm{L})$ & 41217 & 3 & 9 & 1 & 0.003 & 0.117 & 0.018 & 0.035 & No Trend \\
\hline \multirow[t]{17}{*}{ Zinc $(0.021 \mathrm{mg} / \mathrm{M})$} & 2424 & 2 & 11 & 2 & 0.00145 & 0.0347 & 0.0095 & 0.0098 & No Trend \\
\hline & 3424 & 2 & 9 & 1 & 0.00085 & 0.0247 & 0.0059 & 0.0068 & Down, Marginal \\
\hline & 41217 & 3 & 9 & 1 & 0.00435 & 0.0221 & 0.0111 & 0.0055 & No Trend \\
\hline & 2426 & 4 & 10 & 1 & 0.0008 & 0.047 & 0.0090 & 0.0130 & Down, Sig. \\
\hline & 4426 & 4 & 12 & 1 & 0.0008 & 0.026 & 0.0076 & 0.0073 & Down, Sig. \\
\hline & 2417 & 5 & 11 & 1 & 0.0012 & 0.0296 & 0.0086 & 0.0084 & No Trend \\
\hline & 2430 & 7 & 12 & 1 & 0.00165 & 0.0314 & 0.0081 & 0.0077 & Down, Marginal \\
\hline & 2431 & 8 & 9 & 1 & 0.00145 & 0.0534 & 0.0101 & 0.0155 & No Trend \\
\hline & 3431 & 8 & 10 & 1 & 0.00145 & 0.124 & 0.0165 & 0.0359 & No Trend \\
\hline & 2432 & 9 & 10 & 1 & 0.00145 & 0.0271 & 0.0083 & 0.0070 & No Trend \\
\hline & 4432 & 9 & 8 & 1 & 0.00145 & 0.216 & 0.0317 & 0.0697 & No Trend \\
\hline & 2733 & 10 & 9 & 2 & 0.00145 & 0.152 & 0.0279 & 0.0448 & No Trend \\
\hline & 3070 & 11 & 12 & 1 & 0.00085 & 0.0894 & 0.0145 & 0.0241 & No Trend \\
\hline & 3398 & 12 & 10 & 1 & 0.00145 & 0.0568 & 0.0096 & 0.0158 & No Trend \\
\hline & 2434 & 13 & 11 & 1 & 0.00145 & 0.0235 & 0.0075 & 0.0067 & No Trend \\
\hline & 2106 & 14 & 12 & 2 & 0.00085 & 0.0242 & 0.0080 & 0.0083 & No Trend \\
\hline & 3106 & 14 & 12 & 1 & 0.00145 & 0.0789 & 0.0112 & 0.0209 & Down, Marginal \\
\hline
\end{tabular}


TABLE 18: Summary Statistics and Trend Analysis for Routine Monitoring Program Wells Constituent Concentrations Above Final Remediation Levels, 1988-1995 Data

\begin{tabular}{|c|c|c|c|c|c|c|c|c|c|}
\hline Constituent (FRL) & Well & Location & $\begin{array}{l}\text { Number of } \\
\text { Samples (a) }\end{array}$ & $\begin{array}{l}\text { Number of } \\
\text { Samples } \\
\text { Above FRL }\end{array}$ & $\begin{array}{l}\text { Minimum } \\
(p c i / L) \\
(b, c)\end{array}$ & $\begin{array}{l}\text { Maximum } \\
(p c i / L)(d)\end{array}$ & Mean (pci/L) & $\begin{array}{c}\text { Standard } \\
\text { Deviation } \\
\text { (pci/L) }\end{array}$ & Trend $(e)$ \\
\hline Radium-228 (20 pCi/L) & 4424 & 2 & 9 & 1 & 0.00 & 23.3 & 2.99 & 7.17 & Down, Sig. \\
\hline
\end{tabular}

\begin{tabular}{|c|c|c|c|c|c|c|c|c|c|}
\hline Constituent (FRL) & Well & Location & $\begin{array}{l}\text { Number of } \\
\text { Samples }(a)\end{array}$ & $\begin{array}{l}\text { Number of } \\
\text { Samples } \\
\text { Above FRL }\end{array}$ & $\begin{array}{l}\text { Minimum } \\
(\mu g / L)(b, c)\end{array}$ & $\underset{(\mu \mathrm{g} / L)(\mathrm{d})}{\operatorname{Maximum}}$ & Mean $(\mu \mathrm{g} / \mathrm{L})$ & $\begin{array}{c}\text { Standard } \\
\text { Deviation } \\
(\mu \mathrm{gL})\end{array}$ & Trend(e) \\
\hline \multirow[t]{4}{*}{ Total Uranium $(20 \mu \mathrm{g} / \mathrm{L})$} & 3070 & 11 & 20 & $1^{(f)}$ & NA & NA & NA & NA & NA \\
\hline & 3398 & 12 & 12 & ${ }_{1}(f)$ & NA & NA & $\overline{N A}$ & NA & NA \\
\hline & 3069 & 12 & 20 & 8 & 0.5 & 130 & 36.9 & 42.3 & Up, Sig. \\
\hline & 2106 & 14 & 18 & 13 & 1.09 & 88.6 & 49.5 & 22.0 & No Trend \\
\hline $\begin{array}{l}\text { bis(2-Ethylhexyl) } \\
\text { phthalate }(6.0 \mu \mathrm{g} / \mathrm{L})\end{array}$ & 3106 & 14 & 4 & ${ }_{1}(g)$ & NA & NA & NA & NA & NA \\
\hline
\end{tabular}

(a) Number of samples used to perform trend analysis and to assess against FRLs; data qualified with $Z$ or $R$ (see Appendix B) not used in analysis.

(b) For values where the lowest concentration is below the detection limit, the minimum value is set at half the detection limit for trend analysis.

(c) For values where the lowest concentration is below zero, the minimum value is set at zero for trend analysis.

(d) For values where the highest concentration is below the detection limit, the maximum value is set at half the detection limit for trend analysis.

(e) No Trend = no significant trend

Down, Sig. = Down, Significant

Up, Sig. = Up, Significant

(f) Erroneous result in 1994 (concentration of approximately $1 \mathrm{ug} / \mathrm{L}$ for total uranium documented in the 1994 RCRA Annual Report); therefore, trend analysis not performed.

(g) Isolated elevated concentration; therefore, trend analysis not performed.

NA Refer to footnote $f$ and $g$. 


\begin{tabular}{|c|l|c|c|c|}
\hline Well & Location & $\begin{array}{c}\text { Sample } \\
\text { Date }\end{array}$ & $\begin{array}{c}\text { Concentration } \\
\text { (pCi/L) }\end{array}$ & $\begin{array}{c}\text { Concentration } \\
\text { (ppb) }\end{array}$ \\
\hline 2106 & South Plume, Onsite & $2-10-95$ & 47 & 70 \\
\hline 2106 & South Plume, Onsite & $4-10-95$ & 32 & 48 \\
\hline 2106 & South Plume, Onsite & $9-11-95$ & 38 & 56 \\
\hline 2106 & South Plume, Onsite & $9-11-95$ & 36 & 53 \\
\hline 2125 & South Paddys Run Road & $10-3-95$ & 17 & 25 \\
\hline 2166 & South Plume, Onsite & $5-5-95$ & 43 & 64 \\
\hline 2166 & South Plume, Onsite & $6-28-95$ & 51 & 75 \\
\hline 2166 & South Plume, Onsite & $7-5-95$ & 49 & 72 \\
\hline 2545 & South Paddys Run Road & $2-2-95$ & 36 & 54 \\
\hline 2545 & South Paddys Run Road & $5-2-95$ & 30 & 45 \\
\hline 2545 & South Paddys Run Road & $5-5-95$ & 24 & 35 \\
\hline 2550 & South Paddys Run Road & $2-16-95$ & 55 & 82 \\
\hline 2550 & South Paddys Run Road & $6-28-95$ & 50 & 74 \\
\hline 2550 & South Paddys Run Road & $6-29-95$ & 51 & 76 \\
\hline 2550 & South Paddys Run Road & $10-4-95$ & 49 & 72 \\
\hline 2551 & South Paddys Run Road & $2-28-95$ & 19 & 28 \\
\hline 2552 & South Paddys Run Road & $6-29-95$ & 14 & 21 \\
\hline 2552 & South Paddys Run Road & $10-6-95$ & 14 & 21 \\
\hline 2624 & South Paddys Run Road & $2-2-95$ & 54 & 80 \\
\hline 2624 & South Paddys Run Road & $5-5-95$ & 45 & 66 \\
\hline 2624 & South Paddys Run Road & $6-28-95$ & 26 & 39 \\
\hline 2624 & South Paddys Run Road & $7-11-95$ & 66 & 98 \\
\hline 2754 & East Field & $10-6-95$ & 14 & 20 \\
\hline 3062 & South Field, S of Willey Rd & $4-4-95$ & 34 & 51 \\
\hline 3062 & South Field, S of Willey Rd & $7-5-95$ & 47 & 69 \\
\hline 3069 & South Field, S of Willey Rd & $1-10-95$ & 72 & 107 \\
\hline 3069 & South Field, S of Willey Rd & $1-10-95$ & 80 & 118 \\
\hline 3069 & South Field, S of Willey Rd & $4-4-95$ & 81 & 120 \\
\hline 3069 & South Field, S of Willey Rd & $6-28-95$ & 72 & 106 \\
\hline 3069 & South Field, S of Willey Rd & $7-19-95$ & 59 & 88 \\
\hline 3069 & South Field, S of Willey Rd & $9-12-95$ & 88 & 130 \\
\hline 3125 & South Paddys Run Road & $2-10-95$ & 30 & 45 \\
\hline 3125 & South Paddys Run Road & $5-5-95$ & 36 & 54 \\
\hline & & & & \\
\hline
\end{tabular}

\begin{tabular}{|c|l|c|c|c|}
\hline Well & \multicolumn{1}{|c|}{ Location } & $\begin{array}{c}\text { Sample } \\
\text { Date }\end{array}$ & $\begin{array}{c}\text { Concentration } \\
\text { (pCi/L) }\end{array}$ & $\begin{array}{c}\text { Concentration } \\
\text { (ppb) }\end{array}$ \\
\hline 3125 & South Paddys Run Road & $5-30-95$ & 31 & 46 \\
\hline 3125 & South Paddys Run Road & $6-28-95$ & 55 & 82 \\
\hline 3125 & South Paddys Run Road & $10-4-95$ & 38 & 56 \\
\hline 3924 & South Plume, Onsite & $1-30-95$ & 30 & 45 \\
\hline 3924 & South Plume, Onsite & $3-27-95$ & 32 & 47 \\
\hline 3924 & South Plume, Onsite & $3-27-95$ & 32 & 47 \\
\hline 3924 & South Plume, Onsite & $4-24-95$ & 44 & 65 \\
\hline 3924 & South Plume, Onsite & $5-1-95$ & 31 & 46 \\
\hline 3924 & South Plume, Onsite & $6-20-95$ & 35 & 52 \\
\hline 3924 & South Plume, Onsite & $7-25-95$ & 30 & 44 \\
\hline 3924 & South Plume, Onsite & $8-29-95$ & 33 & 49 \\
\hline 3924 & South Plume, Onsite & $9-26-95$ & 33 & 49 \\
\hline 3924 & South Plume, Onsite & $10-2-95$ & 34 & 51 \\
\hline 3924 & South Plume, Onsite & $11-27-95$ & 33 & 49 \\
\hline 3924 & South Plume, Onsite & $12-26-95$ & 30 & 44 \\
\hline 3925 & South Plume, Onsite & $1-30-95$ & 20 & 30 \\
\hline 3925 & South Plume, Onsite & $2-27-95$ & 22 & 33 \\
\hline 3925 & South Plume, Onsite & $4-24-95$ & 22 & 32 \\
\hline 3925 & South Plume, Onsite & $5-1-95$ & 19 & 28 \\
\hline 3925 & South Plume, Onsite & $5-8-95$ & 19 & 28 \\
\hline 3925 & South Plume, Onsite & $5-30-95$ & 19 & 28 \\
\hline 3925 & South Plume, Onsite & $6-20-95$ & 20 & 29 \\
\hline 3925 & South Plume, Onsite & $7-25-95$ & 21 & 31 \\
\hline 3925 & South Plume, Onsite & $8-29-95$ & 20 & 29 \\
\hline 3925 & South Plume, Onsite & $9-25-95$ & 21 & 31 \\
\hline 3925 & South Plume, Onsite & $10-2-95$ & 20 & 30 \\
\hline 3925 & South Plume, Onsite & $10-31-95$ & 20 & 30 \\
\hline 3925 & South Plume, Onsite & $11-28-95$ & 18 & 26 \\
\hline 3925 & South Plume, Onsite & $12-26-95$ & 19 & 28 \\
\hline 11482 & East Field & $4-6-95$ & 15 & 21.8 \\
\hline 11547 & East Field & $2-1-95$ & 134 & 199 \\
\hline 11547 & East Field & $4-6-95$ & 51 & 75 \\
\hline 11547 & East Field & $4-10-95$ & 44 & 65 \\
\hline & & & \\
\hline
\end{tabular}


TABLE 20: $\quad$ Comprehensive Groundwater Samples with Uranium Concentrations Above USEPA Proposed Standard, 1995

page 3 of 4

\begin{tabular}{|c|c|c|c|c|}
\hline Well & Location & $\begin{array}{l}\text { Sample } \\
\text { Date }\end{array}$ & $\begin{array}{c}\text { Concentration } \\
(\mathrm{pCi} / \mathrm{L})\end{array}$ & $\begin{array}{c}\text { Concentration } \\
\text { (ppb) }\end{array}$ \\
\hline 11548 & East Field & $1-24-95$ & 40 & 59 \\
\hline 11548 & East Field & $6-20-95$ & 15 & 22 \\
\hline 11558 & East Field & $3-1-95$ & 1554 & 2300 \\
\hline 11558 & East Field & $4-10-95$ & 22 & 32 \\
\hline 11558 & East Field & $6-20-95$ & 24 & 35 \\
\hline 11558 & East Field & $7-3-95$ & 22 & 32 \\
\hline 11559 & East Field & $10-9-95$ & 16 & 23.75 \\
\hline 31550 & South Plume, Oniste & $4-6-95$ & 88 & 130 \\
\hline 31550 & South Plume, Onsite & $4-6-95$ & 88 & 130 \\
\hline 31550 & South Plume, Onsite & $4-7-95$ & 95 & 140 \\
\hline 31550 & South Plume, Onsite & 4-13-95 & 101 & 150 \\
\hline 31550 & South Plume, Onsite & $5-4-95$ & 95 & 140 \\
\hline 31550 & South Plume, Onsite & $5-9-95$ & 101 & 150 \\
\hline 31550 & South Plume, Onsite & $5-10-95$ & 68 & 100 \\
\hline 31550 & South Plume, Onsite & 5-11-95 & 26 & 39 \\
\hline 31550 & South Plume, Onsite & 5-11-95 & 25 & 37 \\
\hline 31550 & South Plume, Onsite & $5-12-95$ & 22 & 33 \\
\hline 31550 & South Plume, Onsite & $5-12-95$ & 88 & 130 \\
\hline 31550 & South Plume, Onsite & 5-13-95 & 66 & 97 \\
\hline 31550 & South Plume, Onsite & 5-14-95 & 88 & 130 \\
\hline 31550 & South Plume, Onsite & 5-15-95 & 88 & 130 \\
\hline 31550 & South Plume, Onsite & $5-16-95$ & 68 & 100 \\
\hline 31550 & South Plume, Onsite & $10-13-95$ & 14 & 21 \\
\hline 31551 & South Plume, Onsite & $10-9-95$ & 37 & 55 \\
\hline 31551 & South Plume, Onsite & $10-9-95$ & 27 & 40 \\
\hline 31551 & South Plume, Onsite & $10-12-95$ & 25 & 37 \\
\hline 31551 & South Plume, Onsite & $10-12-95$ & 34 & 50 \\
\hline 31551 & South Plume, Onsite & $10-14-95$ & 48 & 71 \\
\hline 31551 & South Plume, Onsite & $10-14-95$ & 37 & 55 \\
\hline 31551 & South Plume, Onsite & $10-14-95$ & 47 & 69 \\
\hline 31551 & South Plume, Onsite & $10-15-95$ & 31 & 46 \\
\hline 31551 & South Plume, Onsite & $10-15-95$ & 49 & 73 \\
\hline 31551 & South Plume, Onsite & $10-16-95$ & 46 & 68 \\
\hline
\end{tabular}

\begin{tabular}{|c|c|c|c|c|}
\hline Well & Location & $\begin{array}{c}\text { Sample } \\
\text { Date }\end{array}$ & $\begin{array}{c}\text { Concentration } \\
(\mathrm{pCi} / \mathrm{L})\end{array}$ & $\begin{array}{l}\text { Concentration } \\
\text { (ppb) }\end{array}$ \\
\hline 31551 & South Plume, Onsite & $10-16-95$ & 35 & 52 \\
\hline 31551 & South Plume, Onsite & $10-16-95$ & 24 & 36 \\
\hline 31552 & South Plume, Onsite & $10-9-95$ & 21 & 31 \\
\hline 31552 & South Plume, Onsite & $10-12-95$ & 20 & 29 \\
\hline 31552 & South Plume, Onsite & $10-13-95$ & 21 & 31 \\
\hline 31552 & South Plume, Onsite & $10-14-95$ & 23 & 34 \\
\hline 31552 & South Plume, Onsite & $10-14-95$ & 22 & 32 \\
\hline 31552 & South Plume, Onsite & $10-15-95$ & 33 & 49 \\
\hline 31552 & South Plume, Onsite & $10-15-95$ & 20 & 30 \\
\hline 31552 & South Plume, Onsite & $10-15-95$ & 28 & 41 \\
\hline 31552 & South Plume, Onsite & $10-16-95$ & 18 & 26 \\
\hline 31552 & South Plume, Onsite & $10-16-95$ & 30 & 44 \\
\hline 31552 & South Plume, Onsite & $10-16-95$ & 30 & 45 \\
\hline 31554 & South Plume, Onsite & $8-3-95$ & 26 & 39 \\
\hline 31554 & South Plume, Onsite & $10-9-95$ & 50 & 74 \\
\hline 31554 & South Plume, Onsite & $10-12-95$ & 38 & 56 \\
\hline 31554 & South Plume, Onsite & $10-13-95$ & 54 & 80 \\
\hline 31554 & South Plume, Onsite & $10-14-95$ & 49 & 72 \\
\hline 31554 & South Plume, Onsite & $10-14-95$ & 61 & 90 \\
\hline 31554 & South Plume, Onsite & $10-15-95$ & 53 & 79 \\
\hline 31554 & South Plume, Onsite & $10-15-95$ & 68 & 100 \\
\hline 31554 & South Plume, Onsite & $10-16-95$ & 53 & 79 \\
\hline 31560 & South of SWRB, Onsite & $8-2-95$ & 20 & 29 \\
\hline 31560 & South of SWRB, Onsite & $8-2-95$ & 162 & 240 \\
\hline 31560 & South of SWRB, Onsite & $8-15-95$ & 189 & 280 \\
\hline 31561 & South of SWRB, Onsite & $8-15-95$ & 31 & 46 \\
\hline 31561 & South of SWRB, Onsite & $8-15-95$ & 29 & 43 \\
\hline 31561 & South of SWRB, Onsite & 8-16-95 & 20 & 30 \\
\hline 31561 & South of SWRB, Onsite & $8-17-95$ & 27 & 40 \\
\hline 31561 & South of SWRB, Onsite & $8-29-95$ & 18 & 26 \\
\hline 31562 & South of SWRB, Onsite & $7-17-95$ & 81 & 120 \\
\hline 31562 & South of SWRB, Onsite & $8-29-95$ & 182 & 270 \\
\hline 31562 & South of SWRB, Onsite & $8-29-95$ & 108 & 160 \\
\hline
\end{tabular}


TABLE 21: Metals in Private Wells, 1995

Page 2 of 3

Metals Listed in Secondary Drinking Water Regulations

\begin{tabular}{|c|c|c|c|c|}
\hline \multirow{2}{*}{$\begin{array}{c}\text { Well } \\
\text { Number (a) }\end{array}$} & \multicolumn{4}{|c|}{ Concentration (mg/L) } \\
\hline & Iron & Manganese & Silver & Zinc \\
\hline 3 & 2.541 & 0.16 & $<0.01$ & $<0.020$ \\
\hline 4 & $<0.100$ & $<0.015$ & $<0.010$ & 0.0733 \\
\hline 8 & $<0.100$ & 0.151 & $<0.010$ & 0.021 \\
\hline 9 & $<0.100$ & 0.243 & $<0.010$ & $<0.020$ \\
\hline 10 & 2.916 & 0.2803 & $<0.010$ & $<0.020$ \\
\hline 11 & $<0.100$ & $<0.015$ & $<0.010$ & 0.154 \\
\hline 12 & 31.370 & 0.144 & $<0.010$ & 6.115 \\
\hline 14 & 0.664 & 0.434 & $<0.010$ & 0.182 \\
\hline 15 & $<0.100$ & $<0.015$ & $<0.010$ & $<0.020$ \\
\hline 16 & 2.106 & 0.329 & $<0.010$ & $<0.020$ \\
\hline 18 & 2.981 & 0.233 & $<0.010$ & $<0.020$ \\
\hline 19 & 1.143 & 0.240 & $<0.010$ & $<0.02$ \\
\hline 21 & 2.005 & 0.239 & $<0.010$ & 0.0535 \\
\hline 22 & $<0.100$ & 0.0641 & $<0.010$ & $<0.020$ \\
\hline 23 & 0.143 & 0.0726 & $<0.010$ & $<0.020$ \\
\hline 24 & $<0.100$ & 0.0456 & $<0.010$ & 0.020 \\
\hline 25 & $<0.100$ & $<0.015$ & $<0.010$ & $<0.020$ \\
\hline 26 & 4.607 & 0.330 & $<0.010$ & 0.0614 \\
\hline 28 & 0.219 & 0.0804 & $<0.01$ & 0.0335 \\
\hline 29 & 2.833 & 0.220 & $<0.010$ & 0.020 \\
\hline 30 & 0.100 & $<0.015$ & $<0.010$ & $<0.020$ \\
\hline 32 & 0.576 & 0.266 & $<0.01$ & $<0.020$ \\
\hline 33 & $<0.100$ & $<0.015$ & $<0.010$ & 0.0338 \\
\hline 34 & 0.3956 & 0.0606 & $<0.010$ & 0.143 \\
\hline 35 & $<0.100$ & $<0.015$ & $<0.010$ & $<0.020$ \\
\hline 36 & 0.185 & $<0.015$ & $<0.010$ & 0.0446 \\
\hline 37 & 0.197 & 0.0165 & $<0.010$ & $<0.020$ \\
\hline 38 & $<0.100$ & $<0.015$ & $<0.010$ & \\
\hline 39 & 0.143 & 0.129 & $<0.010$ & 0.0623 \\
\hline 40 & 0.100 & $<0.015$ & $<0.010$ & 0.128 \\
\hline 41 & $<0.100$ & $<0.015$ & $<0.010$ & 0.0727 \\
\hline 55 & 1.269 & $<0.015$ & $<0.010$ & $<0.020$ \\
\hline $\begin{array}{l}\text { Secondary } \\
\text { Standard }(b)\end{array}$ & 0.3 & 0.05 & 0.10 & 5.0 \\
\hline
\end{tabular}


TABLe 21: Metals in Private Wells, 1995

Metals Not Listed in Drinking Water Regulations

\begin{tabular}{|c|c|c|c|c|c|}
\hline \multirow{2}{*}{$\begin{array}{c}\text { Well } \\
\text { Number }(a)\end{array}$} & \multicolumn{5}{|c|}{ Concentration (mg/L) } \\
\hline & Calcium & Magnesium & Nickel & Potassium & Sodium \\
\hline 3 & 80.220 & 23.000 & $<0.040$ & $<5.000$ & 30.330 \\
\hline 4 & 133.600 & 63.940 & $<0.040$ & $<5.000$ & 52.980 \\
\hline 8 & 101.600 & 29.500 & $<0.040$ & $<5.000$ & 23.250 \\
\hline 9 & 78.510 & 28.460 & $<0.040$ & $<5.000$ & 37.310 \\
\hline 10 & 125.900 & 30.000 & $<0.040$ & $<5.000$ & 11.280 \\
\hline 11 & 79.300 & 22.370 & $<0.040$ & $<5.000$ & 15.710 \\
\hline 12 & 85.140 & 21.320 & $<0.040$ & $<5.000$ & 13.630 \\
\hline 14 & 146.200 & 41.900 & $<0.040$ & 11.040 & 20.360 \\
\hline 15 & 83.020 & 21.350 & $<0.040$ & $<5.000$ & 14.160 \\
\hline 16 & 143.680 & 36.600 & $<0.040$ & $\leq 5.000$ & 98.720 \\
\hline 18 & 110.700 & 26.350 & $<0.040$ & $<5.000$ & 11.540 \\
\hline 19 & 58.120 & 50.770 & $<0.040$ & 70.070 & 23.410 \\
\hline 21 & 107.900 & 25.570 & $<0.040$ & $<5.000$ & 9.852 \\
\hline 22 & 92.400 & 22.440 & $<0.040$ & 3.430 & 15.750 \\
\hline 23 & 94.690 & 25.740 & $<0.040$ & $<5.000$ & 6.153 \\
\hline 24 & 120.500 & 31.750 & $<0.040$ & $<5.000$ & 7.408 \\
\hline 25 & 118.100 & 30.410 & $<0.040$ & $<5.000$ & 10.760 \\
\hline 26 & 102.900 & 24.960 & $<0.040$ & $<5.000$ & 12.090 \\
\hline 28 & 93.870 & 25.740 & $<0.040$ & $<5.000$ & 5.861 \\
\hline 29 & 104.900 & 28.280 & $<0.040$ & $<5.000$ & 9.270 \\
\hline 30 & 88.590 & 24.920 & $<0.040$ & $<5.000$ & 52.980 \\
\hline 32 & 100.300 & 23.900 & $<0.040$ & 7.138 & 5.248 \\
\hline 33 & 123.800 & 31.900 & $<0.040$ & $<5.000$ & 9.000 \\
\hline 35 & 121.300 & 25.100 & $<0.040$ & $<5.000$ & 14.850 \\
\hline 36 & 135.200 & 29.270 & $<0.040$ & $<5.000$ & 9.365 \\
\hline 37 & 73.310 & 29.270 & $<0.040$ & $<5.000$ & 9.365 \\
\hline 38 & 8.236 & $<5.000$ & $<0.040$ & $<5.000$ & $<5.000$ \\
\hline 39 & 225.800 & 33.740 & $<0.040$ & $<5.000$ & 74.000 \\
\hline 40 & 128.700 & 26.330 & $<0.040$ & $<5.000$ & 24.540 \\
\hline 41 & 109.800 & 35.690 & $<0.040$ & $<5.000$ & 35.590 \\
\hline 55 & 135.500 & 34.130 & $<0.040$ & $<5.000$ & 7.877 \\
\hline
\end{tabular}

(a) See Figure 42 on page 121 for well locations. One sample was collected from each well. All samples except \#38 were taken during the month of July. Thirty-eight was taken in November.

(b) USEPA drinking water regulations taken from 40 CFR Part 141 National Interim Primary Drinking Water Regulations - Subpart B - Maximum Contaminant Levels, July 1995 - Subpart G - National Revised Primary Drinking Water Regulations: Maximum

Contaminant Levels, July 1995; and from CFR Part 143, National Secondary Drinking Water Regulations - Section 143.3 - Secondary Maximum Contaminant Levels, July 1995.

(c) USEPA drinking water regulations taken from 40 CFR Part 141 National Interim Primary Drinking Water Regulations - Subpart 1 - Control of Lead and Copper, July 1995. 


\begin{tabular}{|c|c|c|c|c|}
\hline Substance & Well Location (a) & Sample Date & $\begin{array}{c}\text { Concentration } \\
\text { (mg/L) }\end{array}$ & $\begin{array}{l}\text { Primary Standard } \\
(\mathrm{mg} / \mathrm{L})^{(\mathrm{b})}\end{array}$ \\
\hline Arsenic & 2128 South Paddys Run Road & January 9 & 0.0573 & 0.05 \\
\hline Arsenic & 2128 South Paddys Run Road & September 11 & 0.1076 & 0.05 \\
\hline Arsenic & 2548 South Paddys Run Road & January 9 & 0.0521 & 0.05 \\
\hline Arsenic & 2548 South Paddys Run Road & January 31 & 0.0926 & 0.05 \\
\hline Arsenic & 2548 South Paddys Run Road & August 29 & 0.0943 & 0.05 \\
\hline Arsenic & 2548 South Paddys Run Road & August 29 & 0.0792 & 0.05 \\
\hline Arsenic & 2548 South Paddys Run Road & September 5 & 0.0808 & 0.05 \\
\hline Arsenic & 2548 South Paddys Run Road & September 5 & 0.0651 & 0.05 \\
\hline Arsenic & 2548 South Paddys Run Road & September 25 & 0.063 & 0.05 \\
\hline Arsenic & 2636 South Paddys Run Road & January 31 & 0.0818 & 0.05 \\
\hline Arsenic & 2636 South Paddys Run Road & February 7 & 0.0799 & 0.05 \\
\hline Arsenic & 2636 South Paddys Run Road & April 3 & 0.0617 & 0.05 \\
\hline Arsenic & 2636 South Paddys Run Road & April 3 & 0.0648 & 0.05 \\
\hline Arsenic & 2636 South Paddys Run Road & April 10 & 0.0517 & 0.05 \\
\hline Arsenic & 2636 South Paddys Run Road & April 10 & 0.0613 & 0.05 \\
\hline Arsenic & 2636 South Paddys Run Road & April 18 & 0.0657 & 0.05 \\
\hline Arsenic & 2636 South Paddys Run Road & April 18 & 0.066 & 0.05 \\
\hline Arsenic & 2636 South Paddys Run Road & June 19 & 0.0518 & 0.05 \\
\hline Arsenic & 2636 South Paddys Run Road & July 17 & 0.0694 & 0.05 \\
\hline Arsenic & 2636 South Paddys Run Road & July 17 & 0.0646 & 0.05 \\
\hline Arsenic & 2636 South Paddys Run Road & July 24 & 0.061 & 0.05 \\
\hline Arsenic & 2636 South Paddys Run Road & July 31 & 0.0571 & 0.05 \\
\hline Arsenic & 2636 South Paddys Run Road & July 31 & 0.0599 & 0.05 \\
\hline Arsenic & 2636 South Paddys Run Road & August 7 & 0.0536 & 0.05 \\
\hline Arsenic & 2636 South Paddys Run Road & August 7 & 0.0713 & 0.05 \\
\hline Arsenic & 2636 South Paddys Run Road & August 21 & 0.0589 & 0.05 \\
\hline Arsenic & 2636 South Paddys Run Road & August 21 & 0.0579 & 0.05 \\
\hline Arsenic & 2636 South Paddys Run Road & August 29 & 0.0577 & 0.05 \\
\hline Arsenic & 2636 South Paddys Run Road & August 29 & 0.0644 & 0.05 \\
\hline Arsenic & 2636 South Paddys Run Road & September 5 & 0.0626 & 0.05 \\
\hline Arsenic & 2636 South Paddys Run Road & September 5 & 0.0587 & 0.05 \\
\hline Arsenic & 2636 South Paddys Run Road & September 11 & 0.0554 & 0.05 \\
\hline Arsenic & 2636 South Paddys Run Road & September 11 & 0.053 & 0.05 \\
\hline
\end{tabular}




\begin{tabular}{|c|c|c|c|c|}
\hline Substance & Well Location $(\mathrm{a})$ & Sample Date & $\begin{array}{l}\text { Concentration } \\
\text { (mg/L) }\end{array}$ & $\begin{array}{l}\text { Primary Standard } \\
(\mathrm{mg} / \mathrm{L})^{(\mathrm{b})}\end{array}$ \\
\hline Arsenic & 2636 South Paddys Run Road & September 17 & 0.0677 & 0.05 \\
\hline Arsenic & 2636 South Paddys Run Road & September 17 & 0.0722 & 0.05 \\
\hline Arsenic & 2636 South Paddys Run Road & September 25 & 0.076 & 0.05 \\
\hline Arsenic & 2636 South Paddys Run Road & September 25 & 0.07 & 0.05 \\
\hline Arsenic & 2636 South Paddys Run Road & October 2 & 0.0939 & 0.05 \\
\hline Arsenic & 2636 South Paddys Run Road & October 10 & 0.076 & 0.05 \\
\hline Arsenic & 2636 South Paddys Run Road & October 10 & 0.0656 & 0.05 \\
\hline Arsenic & 2636 South Paddys Run Road & October 30 & 0.071 & 0.05 \\
\hline Arsenic & 2636 South Paddys Run Road & October 30 & 0.0785 & 0.05 \\
\hline Arsenic & 2636 South Paddys Run Road & November 27 & 0.0525 & 0.05 \\
\hline Arsenic & 2636 South Paddys Run Road & December 4 & 0.0502 & 0.05 \\
\hline Arsenic & 2636 South Paddys Run Road & December 11 & 0.052 & 0.05 \\
\hline Arsenic & 2636 South Paddys Run Road & December 28 & 0.0981 & 0.05 \\
\hline Arsenic & 2636 South Paddys Run Road & December 28 & 0.0887 & 0.05 \\
\hline Arsenic & 11492 East Field & January 7 & 0.0525 & 0.05 \\
\hline Arsenic & 11546 East Field & January 24 & 0.0717 & 0.05 \\
\hline Arsenic & 11548 East Field & January 24 & 0.0516 & 0.05 \\
\hline Barium & 11498 East Field & January 13 & 2.39 & 1.0 \\
\hline Berylllium & 1161 Production Area, Plant 6 & September 20 & 0.004 & 0.004 \\
\hline Beryllium & 1614 Production Area, Plant 6 & September 19 & 0.0253 & 0.004 \\
\hline Beryllium & 2754 East Field & January 10 & 0.0074 & 0.004 \\
\hline Beryllium & 11491 North Access Road & January 5 & 0.0089 & 0.004 \\
\hline Beryllium & 11492 North Access Road & January 7 & 0.0075 & 0.004 \\
\hline Beryllium & 11493 North Access Road & January 9 & 0.0051 & 0.004 \\
\hline Beryllium & 11497 East Field & January 11 & 0.0056 & 0.004 \\
\hline Beryllium & 11498 East Field & January 13 & 0.0198 & 0.004 \\
\hline Beryllium & 11546 East Field & January 24 & 0.0063 & 0.004 \\
\hline
\end{tabular}




\begin{tabular}{|c|c|c|c|c|}
\hline Substance & Well Location $(a)$ & Sample Date & $\begin{array}{c}\text { Concentration } \\
(\mathrm{mg} / \mathrm{L})\end{array}$ & $\begin{array}{l}\text { Primary Standard } \\
(\mathrm{mg} / \mathrm{L})^{(\mathrm{b})}\end{array}$ \\
\hline Cadmium & 1785 Production Area, Plant 8 & September 15 & 0.0088 & 0.005 \\
\hline Cadmium & 2754 East Field & January 10 & 0.0207 & 0.005 \\
\hline Cadmium & 2754 East Field & July 11 & 0.0649 & 0.005 \\
\hline Cadmium & 2754 East Field & September 6 & 0.018 & 0.005 \\
\hline Cadmium & 11130 South Field & March 16 & 0.0145 & 0.005 \\
\hline Cadmium & 11482 East Field & March 14 & 0.0239 & 0.005 \\
\hline Cadmium & 11484 East Field & March 27 & 0.009 & 0.005 \\
\hline Cadmium & 11486 East Field & March 9 & 0.0111 & 0.005 \\
\hline Cadmium & 11497 East Field & January 11 & 0.016 & 0.005 \\
\hline Cadmium & 11498 East Field & January 13 & 0.078 & 0.005 \\
\hline Cadmium & 11502 East Field & January 25 & 0.0765 & 0.005 \\
\hline Cadmium & 11505 East Field & January 24 & 0.0777 & 0.005 \\
\hline Cadmium & 11557 East Field & March 27 & 0.0139 & 0.005 \\
\hline Cadmium & 11557 East Field & March 27 & 0.0149 & 0.005 \\
\hline Cadmium & 11559 East Field & March 22 & 0.0116 & 0.005 \\
\hline Carbon Tetrachloride & 1149 Production Area & September 20 & 38 & 0.005 \\
\hline Chromium & 1161 Production Area, Plant 6 & September 20 & 0.125 & 0.1 \\
\hline Chromium & 1614 Production Area, Plant 6 & September 19 & 0.848 & 0.1 \\
\hline Chromium & 1784 Production Area & September 18 & 0.153 & 0.1 \\
\hline Chromium & 2754 East Field & January 10 & 7.76 & 0.1 \\
\hline Chromium & 2754 East Field & July 11 & 2.74 & 0.1 \\
\hline Chromium & 11491 East Field & January 5 & 0.114 & 0.1 \\
\hline Chromium & 11492 East Field & January 7 & 0.183 & 0.1 \\
\hline Chromium & 11497 East Field & January 11 & 0.134 & 0.1 \\
\hline Chromium & 11498 East Field & January 25 & 0.478 & 0.1 \\
\hline Chromium & 11502 East Field & January 25 & 0.101 & 0.1 \\
\hline Chromium & 11546 East Field & January 24 & 0.2 & 0.1 \\
\hline Chromium & 11548 East Field & January 24 & 0.118 & 0.1 \\
\hline
\end{tabular}




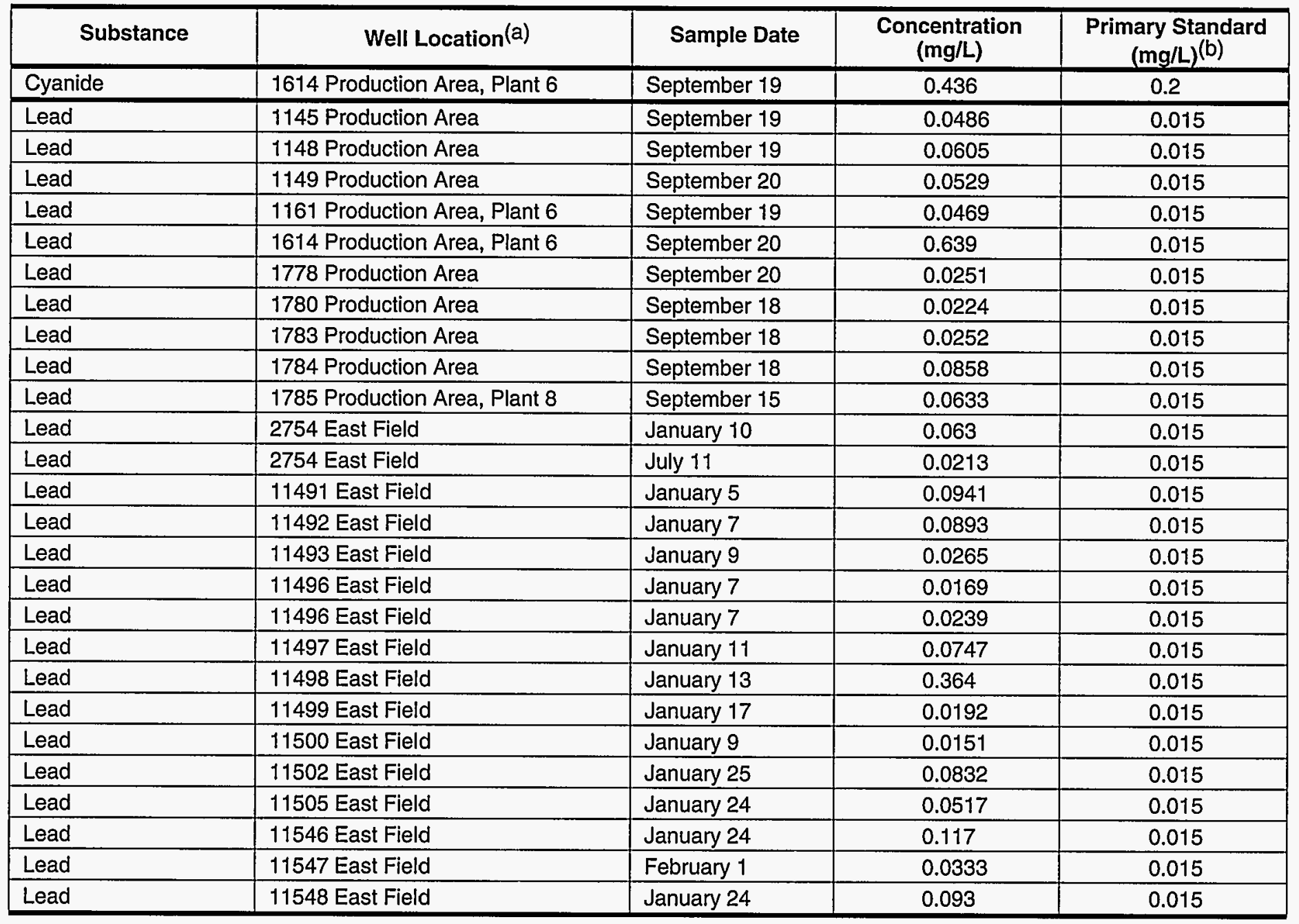




\begin{tabular}{|c|c|c|c|c|}
\hline Substance & Well Location $(\mathrm{a})$ & Sample Date & $\begin{array}{c}\text { Concentration } \\
\text { (mg/L) }\end{array}$ & 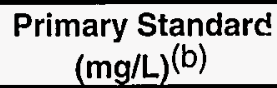 \\
\hline Nickel & 1149 Production Area & September 20 & 0.147 & 0.1 \\
\hline Nickel & 1785 Production Area, Plant 8 & September 15 & 0.112 & 0.1 \\
\hline Nickel & 2754 East Field & January 10 & 3.63 & 0.1 \\
\hline Nickel & 2754 East Field & July 11 & 0.905 & 0.1 \\
\hline Nickel & 2754 East Field & September 6 & 0.269 & 0.1 \\
\hline Nickel & 11491 East Field & January 5 & 0.168 & 0.1 \\
\hline Nickel & 11492 East Field & January 7 & 0.363 & 0.1 \\
\hline Nickel & 11493 East Field & January 11 & 0.138 & 0.1 \\
\hline Nickel & 11497 East Field & January 13 & 0.244 & 0.1 \\
\hline Nickel & 11498 East Field & January 17 & 0.978 & 0.1 \\
\hline Nickel & 11499 East Field & January 25 & 0.122 & 0.1 \\
\hline Nickel & 11502 East Field & January 24 & 0.207 & 0.1 \\
\hline Nickel & 11505 East Field & January 24 & 0.152 & 0.1 \\
\hline Nickel & 11546 East Field & January 24 & 0.331 & 0.1 \\
\hline Nickel & 11548 East Field & January 24 & 0.279 & 0.1 \\
\hline Pentachlorophenol & 1145 Production Area & September 19 & 0.004 & 0.001 \\
\hline Selenium & 1614 Production Area, Plant 6 & September 19 & 0.0646 & 0.05 \\
\hline Tetrachloroethene & 1145 Production Area & September 19 & 4.4 & 0.005 \\
\hline Tetrachloroethene & 1149 Production Area & September 20 & 0.05 & 0.005 \\
\hline Tetrachloroethene & 1784 Production Area & September 18 & 0.007 & 0.005 \\
\hline Thallium & 11482 East Field & April 3 & 0.0038 & 0.0005 \\
\hline Thallium & 11488 South Paddys Run Road & March 22 & 0.0084 & 0.0005 \\
\hline Thallium & 11498 East Field & January 13 & 0.0036 & 0.0005 \\
\hline Thallium & 11558 East Field & March 24 & 0.0031 & 0.0005 \\
\hline Thallium & 11558 East Field & June 20 & 0.0029 & 0.0005 \\
\hline Thallium & 11559 East Field & March 22 & 0.0081 & 0.0005 \\
\hline Trichloroethene & 1145 Production Area & September 19 & 1.2 & 0.005 \\
\hline Trichloroethene & 1148 Production Area & September 19 & 1.0 & 0.005 \\
\hline Trichloroethene & 1149 Production Area & September 20 & 2.8 & 0.005 \\
\hline Trichloroethene & 1614 Production Area, Plant 6 & September 19 & 0.006 & 0.005 \\
\hline Vinyl Chloride & 1785 Production Area, Plant 8 & September 15 & 0.004 & 0.005 \\
\hline
\end{tabular}

(a) See Figure 41 on pages 118 for well locations.

(b) USEPA drinking water regulations taken from 40 CFR Part 141, National InterimPrimary Drinking Water Regulations - Subpart B - Maximum Contaminant Levels, July 1984. 
TABLE 23: Summary of Radiation Dose(a), 1995

\begin{tabular}{|c|c|c|c|}
\hline Type of Dose & Dose $e^{(b)}$ & Standard (c) & $\begin{array}{l}\text { Percent } \\
\text { of Standard }\end{array}$ \\
\hline 1. Individual & mrem(d) & mrem $(d)$ & \\
\hline $\begin{array}{l}\text { A. Maximum individual dose from air emissions, } \\
\text { excluding radon }(e)\end{array}$ & 0.19 & 10 & 1.9 \\
\hline \multicolumn{4}{|l|}{ B. Ingestion $(f)$} \\
\hline $\begin{array}{l}\text { Produce ( } 204 \mathrm{~kg} / \mathrm{year} \text { or } 449 \text { pounds/year) } \\
\text { and milk }\end{array}$ & 0.1 & 100 & 0.1 \\
\hline $\begin{array}{l}\text { Well water } \\
\text { (2 L/day or } 0.5 \text { gallons/day) }\end{array}$ & 0.66 & 100 & 0.66 \\
\hline $\begin{array}{l}\text { Great Miami River fish } \\
\text { (4.4 kg/year or } 10 \text { pounds/year) }\end{array}$ & 0.001 & 100 & 0.001 \\
\hline C. Direct radiation (g) & 0.0 & 100 & 0.0 \\
\hline $\begin{array}{l}\text { D. Radon } \\
\text { Maximum dose to public at the site } \\
\text { fenceline } 8,760 \mathrm{hrs} / \mathrm{year}\end{array}$ & 504 & (h) & \\
\hline II. 80 km (50 miles) Population Dose & person-rem & & \\
\hline $\begin{array}{l}\text { Total collective dose equivalent from air } \\
\text { emissions excluding radon for } 2,740,000 \\
\text { people living within } 80 \mathrm{~km}(50 \text { miles })(\mathrm{e})\end{array}$ & 4.4 & (h) & \\
\hline \multicolumn{4}{|l|}{ III. Other Sources of Dose $(i)$} \\
\hline A. Natural radioactivity & mrem/year & & \\
\hline 1. Radon in homes & 200 & & \\
\hline $\begin{array}{l}\text { 2. Other natural background radiation: cosmic } \\
\text { radiation plus natural terrestrial isotopes, } \\
\text { both external and internal. }\end{array}$ & 100 & & \\
\hline B. Medical diagnosis $(\mathrm{i})$ & 50 & & \\
\hline C. Consumer products & 10 & & \\
\hline D. Atmospheric weapons tests & 4.6 & & \\
\hline
\end{tabular}

(a) Including dose from all radionuclides listed in Table 24.

(b) The effective dose is the weighted sum of doses delivered to the individual organs of the body. Effective doses are comparable to whole body dose equivalents when considering the effects and risks of low-level radiation doses.

(c) Standards are as included in DOE Order 5400.5., "Radiation Protection of the Public and Environment." Also incorporated are the air emission dose standards of regulation 40 CFR 61, Subpart H (NESHAP).

(d) To obtain mSv, multiply mrem by 0.01 .

(e) Effective dose equivalent received as a result of 1995 estimated emissions.

(f) Fifty-year committed dose equivalents based on environmental measurements of uranium in produce, milk, water, and fish.

(g) Whole body dose calculated from highest measurement along the Fernald site fenceline, using environmental

thermoluminescent dosimeters corrected for background.

(h) There are no applicable standards.

(i) From NCRP-93, "lonizing Radiation Exposure of the Population of the United States."

(j) Medical dose estimates are population averages and will not necessarily be applicable to each individual. 
TABLE 24: Estimated Airborne Emissions for the Fernald Site, 1995 (a)

\begin{tabular}{|l|c|c|c|}
\hline Radionuclide & Total Curies & Measured Curies ${ }^{(b)}$ & Estimated Curies $(c)$ \\
\hline Uranium-234 & $8.98 \mathrm{E}-04$ & $8.37 \mathrm{E}-07$ & $8.97 \mathrm{E}-04$ \\
\hline Uranium-235 & $4.81 \mathrm{E}-05$ & $9.88 \mathrm{E}-08$ & $4.80 \mathrm{E}-05$ \\
\hline Uranium-236 & $3.35 \mathrm{E}-05$ & $9.88 \mathrm{E}-08$ & $3.34 \mathrm{E}-05$ \\
\hline Uranium-238 & $1.15 \mathrm{E}-03$ & $2.36 \mathrm{E}-06$ & $1.14 \mathrm{E}-03$ \\
\hline Radium-226 & $8.35 \mathrm{E}-07$ & $9.86 \mathrm{E}-14$ & $8.35 \mathrm{E}-07$ \\
\hline Radium-228 & $3.08 \mathrm{E}-06$ & $3.95 \mathrm{E}-13$ & $3.07 \mathrm{E}-06$ \\
\hline Thorium-228 & $3.24 \mathrm{E}-05$ & $5.61 \mathrm{E}-08$ & $3.23 \mathrm{E}-05$ \\
\hline Thorium-230 & $2.11 \mathrm{E}-05$ & $2.32 \mathrm{E}-07$ & $2.09 \mathrm{E}-05$ \\
\hline Thorium-232 & $5.13 \mathrm{E}-06$ & $3.54 \mathrm{E}-08$ & $5.09 \mathrm{E}-06$ \\
\hline Thorium-234 & $4.76 \mathrm{E}-03$ & N/A & $4.76 \mathrm{E}-03$ \\
\hline
\end{tabular}

(a) Emissions are used as input to the CAP88-PC program which calculates doses from these emission estimates. See page 137 for a description of the CAP88-PC computer program.

(b) Measured emissions are from Building 11 (laundry dryer exhaust) and Building 15 (MEPA/HEPA exhaust).

(c) Includes Plant 4 demolition (preparation), Plant 8 (fugitive emissions), Plant 9 (Zirnlo release), Building 11 (respirator wash facility), Building 20 (cooling water tower), unmonitored stacks, building vents, laboratory hoods and the estimated emissions from waste pit \#5 surface exposure. 
TABLE 25: Radon in Air, 1995

\begin{tabular}{|l|c|c|c|}
\hline \multirow{2}{*}{$\begin{array}{c}\text { Fenceline } \\
\text { Locations }\end{array}$} & \multicolumn{3}{|c|}{ Radon Concentration \pm Precision } \\
\cline { 2 - 4 } & $\begin{array}{c}\text { First } \text { (pCi/L) } \\
\text { of Year }\end{array}$ & $\begin{array}{c}\text { Second Half } \\
\text { of Year }\end{array}$ & $\begin{array}{c}\text { Location } \\
\text { Average }\end{array}$ \\
\hline AMS 2 & $0.5 \pm 0.1$ & $1.0 \pm 0.2$ & $0.8 \pm 0.2$ \\
\hline AMS 4 & $0.5 \pm 0.1$ & $0.9 \pm 0.1$ & $0.7 \pm 0.1$ \\
\hline AMS 6 & $0.5 \pm 0.1$ & $1.0 \pm 0.1$ & $0.8 \pm 0.1$ \\
\hline AMS 7 & $0.6 \pm 0.0$ & $1.1 \pm 0.1$ & $0.9 \pm 0.1$ \\
\hline FEMP A & $0.6 \pm 0.1$ & $0.9 \pm 0.2$ & $0.8 \pm 0.2$ \\
\hline FEMP B & $0.8 \pm 0.2$ & $1.3 \pm 0.1$ & $1.1 \pm 0.2$ \\
\hline FEMP C & $0.4 \pm 0.0$ & $0.7 \pm 0.1$ & $0.6 \pm 0.1$ \\
\hline FEMP D & $0.5 \pm 0.0$ & $1.0 \pm 0.1$ & $0.8 \pm 0.1$ \\
\hline FEMP E & $0.5 \pm 0.1$ & $0.8 \pm 0.1$ & $0.7 \pm 0.1$ \\
\hline FEMP F & $0.5 \pm 0.1$ & $0.9 \pm 0.1$ & $0.7 \pm 0.1$ \\
\hline FEMP G & $0.6 \pm 0.1$ & $0.9 \pm 0.2$ & $0.8 \pm 0.2$ \\
\hline FEMP H & $0.5 \pm 0.1$ & $0.9 \pm 0.2$ & $0.7 \pm 0.2$ \\
\hline FEMP I & $0.6 \pm 0.1$ & $1.6(\mathrm{~b}) \pm 0.6(\mathrm{~b})$ & $0.6 \pm 0.1$ \\
\hline FEMP J & $0.6 \pm 0.0$ & $1.0 \pm 0.2$ & $0.8 \pm 0.2$ \\
\hline FEMP K & $0.5 \pm 0.1$ & $1.0 \pm 0.1$ & $0.8 \pm 0.1$ \\
\hline FEMP L & $0.6 \pm 0.0$ & $1.0 \pm 0.1$ & $0.8 \pm 0.1$ \\
\hline FEMP M & $0.6 \pm 0.2$ & $1.6(\mathrm{~b}) \pm 1.1(\mathrm{~b})$ & $0.6 \pm 0.2$ \\
\hline FEMP N & $0.5 \pm 0.1$ & $3.1(\mathrm{~b}) \pm 0.3(\mathrm{~b})$ & $0.5 \pm 0.1$ \\
\hline FEMP O & $0.5 \pm 0.1$ & $1.5(\mathrm{~b}) \pm 1.1(\mathrm{~b})$ & $0.5 \pm 0.1$ \\
\hline FEMP P & $0.6 \pm 0.1$ & $1.1 \pm 0.2$ & $0.9 \pm 0.2$ \\
\hline Averages & $\mathbf{0 . 6 \pm 0 . 3}$ & $\mathbf{1 . 0 \pm 0 . 3}$ & $\mathbf{0 . 7} \pm 0.4$ \\
\hline
\end{tabular}

(a) See Figure 50 on page 150 for locations.

(b) Data determined to be unusable due to faulty storage.

(c) \pm 1 standard deviation.

\begin{tabular}{|l|c|c|c|}
\hline \multirow{2}{*}{$\begin{array}{c}\text { Background } \\
\text { Locations }(\mathrm{a})\end{array}$} & \multicolumn{3}{|c|}{ Radon Concentration \pm Precision $(\mathrm{c})(\mathrm{pCi} / \mathrm{L})$} \\
\cline { 2 - 4 } & $\begin{array}{c}\text { First Half } \\
\text { of Year }\end{array}$ & $\begin{array}{c}\text { Second Half } \\
\text { of Year }\end{array}$ & $\begin{array}{c}\text { Location } \\
\text { Averages }\end{array}$ \\
\hline Bkgd 1 & $0.4 \pm 0.1$ & $0.8 \pm 0.0$ & $0.6 \pm 0.4$ \\
\hline Bkgd 2 & $0.4 \pm 0.1$ & $0.7 \pm 0.1$ & $0.6 \pm 0.4$ \\
\hline Bkgd 3 & $0.5 \pm 0.1$ & $0.9 \pm 0.1$ & $0.7 \pm 0.5$ \\
\hline Bkgd 4 & $0.3 \pm 0.1$ & $0.8 \pm 0.1$ & $0.6 \pm 0.4$ \\
\hline Bkgd 5 & $0.4 \pm 0.1$ & $0.7 \pm 0.2$ & $0.6 \pm 0.4$ \\
\hline Bkgd 6 & $0.4 \pm 0.1$ & $0.8 \pm 0.1$ & $0.6 \pm 0.4$ \\
\hline Averages & $\mathbf{0 . 4 \pm 0 . 0}$ & $\mathbf{0 . 8} \pm \mathbf{0 . 1}$ & $\mathbf{0 . 7} \pm 0.1$ \\
\hline
\end{tabular}

\begin{tabular}{|l|c|c|c|}
\hline \multirow{2}{*}{$\begin{array}{c}\text { Other } \\
\text { Locations }\end{array}$} & \multicolumn{3}{|c|}{ Radon Concentration \pm Precision } \\
\cline { 2 - 4 } & $\begin{array}{c}\text { (c) } \\
\text { First Half } \\
\text { of Year }\end{array}$ & $\begin{array}{c}\text { Second Half } \\
\text { of Year }\end{array}$ & $\begin{array}{c}\text { Location } \\
\text { Averages }\end{array}$ \\
\hline AMS 1A & $0.6 \pm 0.1$ & $0.9 \pm 0.1$ & $0.8 \pm 0.1$ \\
\hline AMS 8 & $0.4 \pm 0.1$ & $0.8 \pm 0.0$ & $0.6 \pm 0.1$ \\
\hline AMS 9 & $0.4 \pm 0.1$ & $0.9 \pm 0.1$ & $0.7 \pm 0.1$ \\
\hline AMS 10 & $0.6 \pm 0.1$ & $0.9 \pm 0.0$ & $0.8 \pm 0.1$ \\
\hline AMS 11 & $0.5 \pm 0.1$ & $1.0 \pm 0.2$ & $0.8 \pm 0.2$ \\
\hline AMS 12 & $0.4 \pm 0.1$ & $0.8 \pm 0.1$ & $0.6 \pm 0.1$ \\
\hline AMS 13 & $0.5 \pm 0.0$ & $0.8 \pm 0.1$ & $0.7 \pm 0.1$ \\
\hline RES 1 & $0.6 \pm 0.1$ & $1.1 \pm 0.1$ & $0.9 \pm 0.1$ \\
\hline RES 2 & $0.5 \pm 0.1$ & $1.0 \pm 0.2$ & $0.8 \pm 0.2$ \\
\hline RES 3 & $0.7 \pm 0.1$ & $1.0 \pm 0.0$ & $0.9 \pm 0.1$ \\
\hline Averages & $0.5 \pm 0.1$ & $0.9 \pm 0.2$ & $0.7 \pm 0.2$ \\
\hline & & & \\
\hline
\end{tabular}


TABLE 26: DOE Quality Assessment Program for Environmental Radionuclide Analyses Fernald Site Laboratories Performance Results, 1995

\begin{tabular}{|c|c|c|c|c|c|c|}
\hline $\begin{array}{l}\text { Sample } \\
\text { Type }\end{array}$ & $\begin{array}{l}\text { Sample } \\
\text { Number }\end{array}$ & Analysis & Units & $\begin{array}{r}\text { Reported } \\
\text { Site Laboratories }\end{array}$ & EML(a) & $\begin{array}{c}\text { Ratio } \\
\text { Site Value/EML Value }\end{array}$ \\
\hline Soil & $95-03$ & U-234 & $\mathrm{pCi} / \mathrm{g}$ & 2.4975 & 0.8181 & 3.05 \\
\hline Soil & $95-03$ & U-235 & $\mathrm{pCi} / \mathrm{g}$ & 0.10989 & 0.04293 & 2.56 \\
\hline Soil & $95-03$ & U-238 & $\mathrm{pCi} / \mathrm{g}$ & 2.0979 & 0.8532 & 2.46 \\
\hline Air & $95-09$ & uranium & $\mu \mathrm{g} /$ filter & 4.4 & 4.3 & 1.02 \\
\hline Soil & $95-09$ & U-234 & $\mathrm{pCi} / \mathrm{g}$ & 0.7344 & 0.7965 & 0.92 \\
\hline Soil & 95-09 & U-235 & $\mathrm{pCi} / \mathrm{g}$ & 0.03618 & 0.03942 & 0.92 \\
\hline Soil & $95-09$ & U-238 & $\mathrm{pCi} / \mathrm{g}$ & 0.7074 & 0.8208 & 0.86 \\
\hline Water & $95-09$ & uranium & $\mu \mathrm{g} / \mathrm{ml}$ & 0.028 & 0.025 & 1.12 \\
\hline
\end{tabular}

(a) DOE's Environmental Measurements Laboratory (EML). 
TABLE 27: USEPA Quality Assurance Program for WastewaterAnalyses Fernald Site Laboratories Performance Evaluation, 1995(a)

\begin{tabular}{|c|c|c|c|c|c|}
\hline Parameter & Units(b) & $\begin{array}{l}\text { Valu } \\
\text { Site } \\
\text { Laboratories }\end{array}$ & True $(c)$ & $\begin{array}{c}\text { USEPA } \\
\text { Acceptance } \\
\text { Limits }(d)\end{array}$ & $\begin{array}{c}\text { USEPA } \\
\text { Performance } \\
\text { Evaluation }(\mathrm{e})\end{array}$ \\
\hline Chromium & $\mu \mathrm{g} / \mathrm{L}$ & 102.7 & 97.2 & $82.9-111$ & ACCEPTABLE \\
\hline Copper & $\mu \mathrm{g} / \mathrm{L}$ & 52.2 & 50.4 & $41.6-58$ & ACCEPTABLE \\
\hline Nickel & $\mu \mathrm{g} / \mathrm{L}$ & 80.7 & 80.9 & $67.7-91.9$ & ACCEPTABLE \\
\hline $\mathrm{pH}$ & S.U. & 7.62 & 7.6 & $7.4-7.76$ & ACCEPTABLE \\
\hline Total Suspended Solids & $\mathrm{mg} / \mathrm{L}$ & 33.3 & 38 & $27.9-40.1$ & ACCEPTABLE \\
\hline Oil \& Grease & $\mathrm{mg} / \mathrm{L}$ & 10.8 & 11 & $5.08-15.1$ & ACCEPTABLE \\
\hline Ammonia - Nitrogen & $\mathrm{mg} / \mathrm{L}$ & 8.59 & 8.8 & $7.05-10.4$ & ACCEPTABLE \\
\hline Nitrate - Nitrogen & $\mathrm{mg} / \mathrm{L}$ & 6.2 & 6.02 & $4.85-7.06$ & ACCEPTABLE \\
\hline 5 Day BOD & $\mathrm{mg} / \mathrm{L}$ & 33.89 & 30.2 & $17.3-42.3$ & ACCEPTABLE \\
\hline Carbonaceous BOD & $\mathrm{mg} / \mathrm{L}$ & 29.29 & 26.2 & $10-40.8$ & ACCEPTABLE \\
\hline
\end{tabular}

(a) USEPA Discharge Monitoring Report (DMR) Quality Assurance (QA) Program. The Fernald site, along with all other National Pollutant Discharge Elimination Systems (NPDES) permit holders, is required to participate in these annual laboratory performance evaluation studies (Section 308[a] of the Clean Water Act).

(b) S.U. stands for standard units.

(c) Actual parameter concentrations established by USEPA based on theoretical calculations or a reference value when necessary.

(d) Laboratory measured values which fall within this range are considered acceptable by USEPA.

(e) USEPA DMR-QA Study Number 15 conducted during 1995. 
TABLE 28: Proficiency Environmental Testing Quality Assurance Program for Water Analyses, 1995

Summary of Performance of the Fernald Site's Laboratories

\begin{tabular}{|c|c|c|c|c|c|c|c|c|c|c|}
\hline Parameter & Units & $\begin{array}{c}\text { Number } \\
\text { of } \\
\text { Analyses }\end{array}$ & $\begin{array}{l}\text { Range } \\
\text { of True } \\
\text { Values }\end{array}$ & $\begin{array}{l}\text { Perc } \\
\text { Min. }\end{array}$ & $\begin{array}{l}\text { t Recov } \\
\text { Max. }\end{array}$ & $\begin{array}{l}\text { (a) } \\
\text { Avg. }\end{array}$ & Min. & $\begin{array}{l}\text { Deviatior } \\
\text { om Mear } \\
\text { Max. }\end{array}$ & Avg. & $\begin{array}{c}\text { Percentage } \\
\text { Acceptable(c) }\end{array}$ \\
\hline $\begin{array}{l}\text { Biochemical Oxygen } \\
\text { Demand }\end{array}$ & $\mathrm{mg} / \mathrm{L}$ & 20 & $15.5-289$ & 83 & 112 & 100 & 0.015 & 0.94 & 0.45 & 100 \\
\hline Chemical Oxygen Demand & $\mathrm{mg} / \mathrm{L}$ & 6 & $23.5-469$ & 98 & 102 & 100 & 0.36 & 0.91 & 0.55 & 100 \\
\hline Total Organic Carbon & $\mathrm{mg} / \mathrm{L}$ & 4 & $9.70-105$ & 97 & 108 & 103 & 0.12 & 0.94 & 103 & 100 \\
\hline Ammonia Nitrogen as $\mathrm{N}$ & $\mathrm{mg} / \mathrm{L}$ & 22 & $0.22-17.1$ & 62 & 107 & 94 & 0.089 & 2.37 & 1.14 & 95 \\
\hline Nitrate Nitrogen as $\mathrm{N}$ & $\mathrm{mg} / \mathrm{L}$ & 22 & $0.30-21.7$ & 99 & 109 & 103 & 0.223 & 1.247 & 0.58 & 100 \\
\hline Orthophosphate as $P$ & $\mathrm{mg} / \mathrm{L}$ & 20 & $0.58-11.2$ & 96 & 105 & 101 & 0.015 & 1.143 & 0.30 & 100 \\
\hline Total Phosphorus as $\mathrm{P}$ & $\mathrm{mg} / \mathrm{L}$ & 4 & $0.19-11.3$ & 70 & 111 & 92 & 0.167 & 1.512 & 0.92 & 100 \\
\hline Total Suspended Solids & $\mathrm{mg} / \mathrm{L}$ & 22 & $35.4-495$ & 93 & 102 & 108 & 0.131 & 0.994 & 2.46 & 90 \\
\hline Total Dissolved Solids & $\mathrm{mg} / \mathrm{L}$ & 22 & $152-1800$ & 27 & 410 & 111 & 0.29 & 28.83 & 2.38 & 90 \\
\hline Total Solids & $\mathrm{mg} / \mathrm{L}$ & 22 & $278-2170$ & 27 & 397 & 110 & 0.022 & 32.09 & 3.12 & 90 \\
\hline Oil and grease & $\mathrm{mg} / \mathrm{L}$ & 21 & $5.00-97.2$ & 70 & 105 & 87 & 0.048 & 1.553 & 0.53 & 100 \\
\hline Alkalinity as $\mathrm{CaSO}_{3}$ & $\mathrm{mg} / \mathrm{L}$ & 22 & $16.5-184$ & 40 & 117 & 100 & 0.05 & 11.57 & 0.99 & 95 \\
\hline Calcium & $\mathrm{mg} / \mathrm{L}$ & 22 & $5.98-52.5$ & 37 & 109 & 94 & 0.0002 & 8.618 & 1.53 & 86 \\
\hline Chloride & $\mathrm{mg} / \mathrm{L}$ & 22 & $24.1-471$ & 10 & 499 & 112 & 0.023 & 56.98 & 4.52 & 83 \\
\hline Conductivity & $\mu \mathrm{mho} / \mathrm{cm}$ & 22 & $201-2390$ & 1.02 & 121 & 92 & 0.012 & 19.39 & 2.31 & 82 \\
\hline Magnesium & $\mathrm{mg} / \mathrm{L}$ & 22 & $1.06-46.8$ & 84 & 107 & 98 & 0.027 & 2.807 & 0.84 & 95 \\
\hline Potassium & $\mathrm{mg} / \mathrm{L}$ & 22 & $3.26-262$ & 85 & 100 & 96 & 0.04 & 2.133 & 0.61 & 100 \\
\hline Sodium & $\mathrm{mg} / \mathrm{L}$ & 22 & $23.6-212$ & 87 & 104 & 97 & 0.003 & 2.689 & 0.74 & 95 \\
\hline Sulfate & $\mathrm{mg} / \mathrm{L}$ & 22 & $12.7-214$ & 89 & 181 & 104 & 0.021 & 9.835 & 0.93 & 95 \\
\hline Total Hardness as $\mathrm{CaCO}_{3}$ & $\mathrm{mg} / \mathrm{L}$ & 22 & $21.5-191$ & 73 & 108 & 98 & 0.156 & 9.536 & 0.95 & 95 \\
\hline $\mathrm{pH}$ & S.U. & 22 & $4.05-9.40$ & 97 & 101 & 99 & 0.096 & 0.731 & 0.37 & 100 \\
\hline Aluminum & $\mu \mathrm{g} / \mathrm{L}$ & 22 & $41.6-670$ & 28 & 111 & 95 & 0.013 & 14.67 & 1.46 & 86 \\
\hline Arsenic & $\mu \mathrm{g} / \mathrm{L}$ & 20 & $8.9-494$ & 83 & 112 & 87 & 0.035 & 2.411 & 0.71 & 100 \\
\hline Barium & $\mu \mathrm{g} / \mathrm{L}$ & 22 & $97.8-2370$ & 92 & 100 & 96 & 0.061 & 2.331 & 0.74 & 100 \\
\hline Beryllium & $\mu \mathrm{g} / \mathrm{L}$ & 22 & $18.3-470$ & 97 & 105 & 101 & 0.024 & 1.044 & 0.51 & 100 \\
\hline Cadmium & $\mu \mathrm{g} / \mathrm{L}$ & 22 & $25.6-252$ & 114 & 119 & 107 & 0.01 & 2.698 & 1.03 & 95 \\
\hline Chromium & $\mu \mathrm{g} / \mathrm{L}$ & 22 & $66.9-856$ & 99 & 111 & 102 & 0.03 & 0.965 & 0.38 & 100 \\
\hline Cobalt & $\mu \mathrm{g} / \mathrm{L}$ & 22 & $42.5-718$ & 100 & 111 & 105 & 0.031 & 1.873 & 1.08 & 100 \\
\hline Copper & $\mu \mathrm{g} / \mathrm{L}$ & 22 & $22.7-800$ & 94 & 107 & 103 & 0.11 & 1.457 & 0.99 & 100 \\
\hline Iron & $\mu \mathrm{g} / \mathrm{L}$ & 22 & $96.4-618$ & 95 & 110 & 103 & 0.12 & 2.51 & 0.73 & 100 \\
\hline Lead & $\mu g / L$ & 20 & $94.1-521$ & 89 & 110 & 88 & 0.283 & 1.773 & 0.79 & 100 \\
\hline Manganese & $\mu \mathrm{g} / \mathrm{L}$ & 22 & $52.6-738$ & 100 & 108 & 104 & 0.015 & 1.796 & 0.88 & 100 \\
\hline Mercury & $\mu \mathrm{g} / \mathrm{L}$ & 20 & $0.88-12.7$ & 73 & 109 & 89 & 0.01 & 1.87 & 0.43 & 100 \\
\hline
\end{tabular}


TABLE 28: Proficiency Environmental Testing Quality Assurance Program for Water Analyses, 1995

Summary of Performance of the Fernald Site's Laboratories

\begin{tabular}{|c|c|c|c|c|c|c|c|c|c|c|}
\hline \multirow[t]{2}{*}{ Parameter } & \multirow[t]{2}{*}{ Units } & \multirow{2}{*}{$\begin{array}{c}\text { Number } \\
\text { of } \\
\text { Analyses }\end{array}$} & \multirow{2}{*}{$\begin{array}{l}\text { Range } \\
\text { of True } \\
\text { Values }\end{array}$} & \multicolumn{3}{|c|}{ Percent Recovery(a) } & \multicolumn{3}{|c|}{$\begin{array}{l}\text { Deviations } \\
\text { from Mean }(b)\end{array}$} & \multirow{2}{*}{$\begin{array}{c}\text { Percentage } \\
\text { Acceptable (c) }\end{array}$} \\
\hline & & & & & & & Min. & Max. & Avg. & \\
\hline Nickel & $\mu \mathrm{g} / \mathrm{L}$ & 22 & $28.2-623$ & 96 & 110 & 105 & 0.139 & 2.215 & 0.92 & 100 \\
\hline Selenium & $\mu \mathrm{g} / \mathrm{L}$ & 18 & $9.94-143$ & 78 & 117 & 85 & 0.37 & 2.096 & 0.59 & 100 \\
\hline Silver & $\mu \mathrm{g} / \mathrm{L}$ & 22 & $14.9-205$ & 87 & 114 & 102 & 0.065 & 1.374 & 0.47 & 100 \\
\hline Vanadium & $\mu \mathrm{g} / \mathrm{L}$ & 22 & $61.0-2000$ & 98 & 111 & 103 & 0.011 & 1.833 & 0.70 & 100 \\
\hline Zinc & $\mu \mathrm{g} / \mathrm{L}$ & 22 & $24.9-410$ & 96 & 105 & 100 & 0.014 & 0.888 & 0.29 & 100 \\
\hline Fluoride & $\mathrm{mg} / \mathrm{L}$ & 21 & $0.060-15.1$ & 93 & 103 & 95 & 0.138 & 1.533 & 0.50 & 100 \\
\hline Total Organic Halide & $\mu \mathrm{g} / \mathrm{L}$ & 4 & $10.7-731$ & 82 & 102 & 93 & 0.13 & 1.6 & 0.55 & 100 \\
\hline Hexavalent Chromium & $\mathrm{mg} / \mathrm{L}$ & 22 & $0.016-514$ & 91 & 102 & 71 & 0.106 & 1.736 & 0.25 & 100 \\
\hline Uranium & $\mu \mathrm{g} / \mathrm{L}$ & 22 & $30.9-961$ & 89 & 112 & 99 & 0.217 & 1.331 & 0.68 & 100 \\
\hline Benzene & $\mu \mathrm{g} / \mathrm{L}$ & 16 & $11.8-153$ & 93 & 114 & 104 & 0.05 & 1.72 & 0.71 & 100 \\
\hline Chlorobenzene & $\mu \mathrm{g} / \mathrm{L}$ & 16 & $27.2-173$ & 90 & 123 & 103 & 0.095 & 1.44 & 0.60 & 100 \\
\hline 1,2 Dichlorobenzene & $\mu \mathrm{g} / \mathrm{L}$ & 12 & $21.7-125$ & 93 & 112 & 102 & 0.062 & 0.932 & 0.38 & 100 \\
\hline 1,4 Dichlorobenzene & $\mu \mathrm{g} / \mathrm{L}$ & 8 & $8.5-56.6$ & 94 & 95 & 31 & 0.509 & 0.557 & 0.17 & 100 \\
\hline Ethyl Benzene & $\mu \mathrm{g} / \mathrm{L}$ & 16 & $7.35-168$ & 90 & 107 & 98 & 0.013 & 0.896 & 0.30 & 100 \\
\hline Toluene & $\mu \mathrm{g} / \mathrm{L}$ & 16 & $8.84-117$ & 89 & 115 & 89 & 0.022 & 1.705 & 0.57 & 100 \\
\hline Bromodichloromethane & $\mu \mathrm{g} / \mathrm{L}$ & 2 & $32.1-95.9$ & 103 & 115 & 54 & 0.212 & 1.116 & 0.33 & 100 \\
\hline Bromoform & $\mu \mathrm{g} / \mathrm{L}$ & 8 & $28.0-177$ & 86 & 111 & 80 & 0.045 & 0.959 & 0.41 & 100 \\
\hline Carbon Tetrachloride & $\mu \mathrm{g} / \mathrm{L}$ & 14 & $14.5-139$ & 87 & 161 & 90 & 0.052 & 3.936 & 0.64 & 93 \\
\hline Chloroform & $\mu \mathrm{g} / \mathrm{L}$ & 12 & $6.14-174$ & 92 & 128 & 106 & 0.086 & 2.158 & 0.74 & 100 \\
\hline 1,2 Dichloreoethane & $\mu \mathrm{g} / \mathrm{L}$ & 10 & $12.9-279$ & 101 & 131 & 95 & 0.042 & 2.344 & 0.97 & 100 \\
\hline Methylene Chloride & $\mu \mathrm{g} / \mathrm{L}$ & 14 & $21.7-183$ & 81 & 130 & 100 & 0.042 & 2.168 & 0.67 & 100 \\
\hline $1,1,2,2$ Tetrachloroethane & $\mu \mathrm{g} / \mathrm{L}$ & 4 & $28.3-193$ & 39 & 119 & 54 & 0.672 & 1.138 & 1.08 & 75 \\
\hline Tetrachloroethylene & $\mu g / L$ & 14 & $32.6-63.3$ & 82 & 102 & 93 & 0.028 & 0.963 & 0.41 & 100 \\
\hline 1,1,1 Trichloroethane & $\mu \mathrm{g} / \mathrm{L}$ & 16 & $15.3-125$ & 87 & 146 & 103 & 0.076 & 2.705 & 0.62 & 94 \\
\hline 1,1,2 Trichloroethane & $\mu \mathrm{g} / \mathrm{L}$ & 8 & $23.7-223$ & 101 & 118 & 60 & 0.245 & 2.383 & 0.40 & 88 \\
\hline Trichloroethylene & $\mu \mathrm{g} / \mathrm{L}$ & 18 & $7.59-218$ & 84 & 149 & 88 & 0.044 & 4.967 & 0.65 & 94 \\
\hline Total & & 1,060 & & & & & & & & 97 \\
\hline
\end{tabular}

(a) Percent recovery is the site's measured value, divided by the true parameter concentration, multiplied by 100.

(b) The standard deviation indicates the closeness of the site's measurement result to the mean value reported by Analytical Products Group, Inc., which conducts the testing program. The standard deviation would be 0.00 if the site's result and the mean value were exactly the same. The mean value is calculated from the results obtained by all laboratories participating in the control program. Any measurement results which are significantly different from the true parameter concentration or statistically different from the majority of results obtained by the other laboratories are not included in evaluating the mean value.

(c) This is the percentage of the site's measurement results for each parameter which met the USEPA "Acceptable" criteria of being within 2.58 standard deviations of the mean value. 
Table 29: Fernald Site - OEPA Sampling Comparison, 1995

Groundwater Sampling for Uranium

\begin{tabular}{|c|c|c|c|}
\hline $\begin{array}{l}\text { Sampling } \\
\text { Location(a) }\end{array}$ & $\begin{array}{l}\text { Sampling } \\
\text { Date }\end{array}$ & $\begin{array}{l}\text { Concentrat } \\
\text { Fernald Site }\end{array}$ & $\begin{array}{c}\mathrm{Ci} / \mathrm{L})^{(\mathrm{b})} \\
\text { OEPA }\end{array}$ \\
\hline 4 & January 25 & 2.5 & 2.2 \\
\hline 4 & February 22 & 1.9 & 2.0 \\
\hline 4 & March 29 & 1.6 & 1.7 \\
\hline 4 & April 26 & 1.8 & 1.6 \\
\hline 4 & May 24 & 2.2 & 2.3 \\
\hline 4 & June 28 & 1.6 & 1.7 \\
\hline 4 & July 26 & 1.6 & 1.47 \\
\hline 4 & August 23 & 1.7 & 1.69 \\
\hline 4 & September 27 & 1.3 & 1.40 \\
\hline 4 & October 25 & 1.5 & 1.50 \\
\hline 4 & November 29 & 1.6 & 1.60 \\
\hline 4 & December 27 & 2.0 & 1.9 \\
\hline 14 & January 25 & 2.3 & 2.2 \\
\hline 14 & February 22 & 2.2 & 2.1 \\
\hline 14 & March 29 & 2.2 & 2.2 \\
\hline 14 & April 26 & 2.2 & 2.1 \\
\hline 14 & May 24 & 2.0 & 2.0 \\
\hline 14 & June 28 & 2.2 & 2.1 \\
\hline 14 & July 26 & 2.3 & 2.08 \\
\hline 14 & August 23 & 2.3 & 2.1 \\
\hline 14 & September 27 & 2.3 & 2.4 \\
\hline 14 & October 25 & 2.5 & 2.5 \\
\hline 14 & November 29 & 2.4 & 2.4 \\
\hline 14 & December 27 & 2.7 & 2.5 \\
\hline $15^{(c)}$ & January 25 & 160.0 & 170.0 \\
\hline 15 & February 22 & 160.0 & 161.0 \\
\hline 15 & March 29 & 160.0 & 163.0 \\
\hline 15 & April 26 & 170.0 & 155.0 \\
\hline 15 & May 24 & 170.0 & 176.0 \\
\hline 15 & June 28 & 160.0 & 162.0 \\
\hline 15 & July 26 & 160.0 & 155.6 \\
\hline 15 & August 23 & 180.0 & 156.0 \\
\hline 15 & September 27 & 170.0 & 170.0 \\
\hline 15 & October 25 & 170.0 & 170.0 \\
\hline 15 & November 29 & 170.0 & 170.0 \\
\hline 15 & December 27 & 170.0 & 160.0 \\
\hline
\end{tabular}

Groundwater Sampling for Uranium

\begin{tabular}{|c|c|c|c|}
\hline $\begin{array}{l}\text { Sampling } \\
\text { Location (a) }\end{array}$ & $\begin{array}{c}\text { Sampling } \\
\text { Date }\end{array}$ & $\begin{array}{l}\text { Concentr } \\
\text { Fernald Site }\end{array}$ & $\begin{array}{l}\text { (pCi/L) } \\
\text { OEPA }\end{array}$ \\
\hline 19 & January 25 & NS & NS \\
\hline 19 & February 22 & $<0.1$ & $<0.1$ \\
\hline 19 & March 29 & $<0.1$ & $<0.1$ \\
\hline 19 & April 26 & $<0.1$ & $<0.1$ \\
\hline 19 & May 24 & $<0.1$ & $<0.1$ \\
\hline 19 & June 28 & 3.0 & 0.01 \\
\hline 19 & July 26 & $<0.1$ & 0.01 \\
\hline 19 & August 23 & $<0.1$ & 0.01 \\
\hline 19 & September 27 & $<0.1$ & 0.01 \\
\hline 19 & October 25 & $<0.1$ & $<0.1$ \\
\hline 19 & November 29 & 0.1 & 0.10 \\
\hline 19 & December 27 & NS & NS \\
\hline 24 & January 25 & 0.5 & 0.5 \\
\hline 39 & February 22 & 5.2 & 5.3 \\
\hline 18 & March 29 & 0.5 & 0.4 \\
\hline 33 & April 26 & 0.5 & 0.5 \\
\hline 36 & May 24 & 1.2 & 1.1 \\
\hline 21 & June 28 & 0.4 & 0.35 \\
\hline 30 & July 26 & 0.8 & 0.70 \\
\hline 10 & August 23 & 0.5 & 0.43 \\
\hline 32 & September 27 & $<0.1$ & 0.03 \\
\hline 3 & October 25 & $<0.1$ & 0.1 \\
\hline 11 & November 29 & 1.7 & 1.7 \\
\hline 26 & December 27 & 0.2 & 0.039 \\
\hline
\end{tabular}
(a) See Figure 43 on page 122 for locations.
(b) To obtain $\mathrm{Bq} / \mathrm{L}$, multiply $\mathrm{pCi} / \mathrm{L}$ by 0.037 .
(c) Well 15 is used for monitoring purposes only. 
Table 31: Fernald Site - OEPA Sampling Comparison, 1995

Surface Water Sampling for Uranium and Radium

\begin{tabular}{|c|c|c|c|c|c|c|c|}
\hline \multirow[b]{2}{*}{$\begin{array}{l}\text { Sampling } \\
\text { Location }\end{array}$} & \multirow[b]{2}{*}{$\begin{array}{l}\text { Sampling } \\
\text { Date }\end{array}$} & \multicolumn{3}{|c|}{ Fernald Site Results } & \multicolumn{3}{|c|}{ OEPA Results } \\
\hline & & $\begin{array}{c}\text { Total } \\
\text { Uranium } \\
\text { (pCi/L) }\end{array}$ & $\begin{array}{l}\mathrm{Ra}-226 \\
(\mathrm{pCi} / \mathrm{L})\end{array}$ & $\begin{array}{l}. \mathrm{Ra}-228 \\
(\mathrm{pCi} / \mathrm{L})\end{array}$ & $\begin{array}{l}\text { Total } \\
\text { Uranium } \\
\text { (pCi/L) }\end{array}$ & $\begin{array}{l}\mathrm{Ra}-226 \\
(\mathrm{pCi} / \mathrm{L})\end{array}$ & $\begin{array}{l}\text { Ra-228 } \\
\text { (pCi/L) }\end{array}$ \\
\hline W1 & $01 / 25 / 95$ & 1.4 & 0.15 & 2.80 & 1.2 & $<M D C$ & 3.50 \\
\hline W1 & $02 / 22 / 95$ & 0.9 & 0.07 & 2.90 & 1.2 & 0.20 & 0.39 \\
\hline W1 & $03 / 29 / 95$ & 1.3 & 0.12 & 7.10 & 1.4 & $<\mathrm{MDC}$ & $<\mathrm{MDC}$ \\
\hline W3 & $01 / 25 / 95$ & 1.2 & 0.12 & 0.29 & 1.2 & $<\mathrm{MDC}$ & $<\mathrm{MDC}$ \\
\hline W3 & $02 / 22 / 95$ & 1.1 & 0.13 & 3.80 & 1.2 & 0.21 & 1.30 \\
\hline W3 & $03 / 29 / 95$ & 1.3 & 0.17 & 2.90 & 1.8 & $<M D C$ & $<M D C$ \\
\hline W3 & $04 / 26 / 95$ & 1.1 & 0.16 & 3.40 & 1.1 & $<M B C$ & $<M D C$ \\
\hline W3 & $05 / 24 / 95$ & 1.0 & 0.17 & $<M D C$ & 1.2 & $<M D C$ & $<M D C$ \\
\hline W3 & $06 / 28 / 95$ & 1.0 & 0.28 & $\leq \mathrm{MDC}$ & 1.1 & 0.49 & 1.39 \\
\hline W3 & $07 / 26 / 95$ & 0.9 & 0.17 & $<M D C$ & 0.9 & 0.22 & 3.68 \\
\hline W3 & $08 / 23 / 95$ & 0.9 & 0.20 & $<M D C$ & 1.0 & 0.30 & 1.02 \\
\hline W3 & $09 / 27 / 95$ & 0.9 & 0.14 & $<M D C$ & 1.1 & 0.13 & 0.60 \\
\hline W3 & $10 / 25 / 95$ & 1.1 & 0.23 & $<M D C$ & 1.3 & 0.24 & 1.10 \\
\hline W3 & $11 / 29 / 95$ & 1.4 & 0.15 & $<\mathrm{MDC}$ & 1.4 & 0.26 & 0.85 \\
\hline W3 & $12 / 27 / 95$ & 1.1 & 0.10 & $<\mathrm{MDC}$ & 1.1 & 0.18 & 0.60 \\
\hline W4 & $01 / 25 / 95$ & 1.2 & 0.05 & 0.24 & 1.3 & $<M D C$ & 1.60 \\
\hline W4 & $02 / 22 / 95$ & 1.1 & 0.09 & 2.90 & 1.1 & 0.18 & 0.61 \\
\hline W4 & $03 / 29 / 95$ & 1.3 & 0.19 & 2.90 & 1.4 & $<M D C$ & $<M D C$ \\
\hline W5 & $02 / 22 / 95$ & 0.5 & 0.04 & 2.90 & 0.7 & $<M D C$ & $<M D C$ \\
\hline W5 & $03 / 29 / 95$ & 0.8 & 0.06 & $<\mathrm{MDC}$ & $<M D C$ & $<M D C$ & $<\mathrm{MDC}$ \\
\hline W7 & $02 / 22 / 95$ & 4.3 & 0.06 & 2.90 & 3.8 & $<M D C$ & 2.48 \\
\hline W7 & $04 / 26 / 95$ & 2.3 & 0.07 & 2.90 & 3.1 & $<M D C$ & 1.19 \\
\hline W7 & $05 / 24 / 95$ & 3.6 & 0.06 & $<\mathrm{MDC}$ & 2.8 & $<M D C$ & $<M D C$ \\
\hline W8 & $02 / 22 / 95$ & 4.1 & $\mathrm{NA}$ & NA & 3.9 & $<\mathrm{MDC}$ & $<M D C$ \\
\hline W8 & $03 / 29 / 95$ & 2.3 & NA & NA & 3.5 & $<M D C$ & $<M D C$ \\
\hline W9 & $03 / 29 / 95$ & 1.8 & $\mathrm{NA}$ & $\mathrm{NA}$ & 2.3 & $<M D C$ & $<M D C$ \\
\hline W9 & $04 / 26 / 95$ & 1.6 & $\mathrm{NA}$ & NA & 1.4 & NA & $N A$ \\
\hline W9 & $05 / 24 / 95$ & 1.2 & NA & NA & 1.2 & NA & $\mathrm{NA}$ \\
\hline W9 & $06 / 28 / 95$ & 0.7 & NA & NA & 0.7 & $\mathrm{NA}$ & NA \\
\hline W9 & $07 / 26 / 95$ & 0.9 & NA & NA & 0.9 & $\mathrm{NA}$ & $\mathrm{NA}$ \\
\hline W9 & $08 / 23 / 95$ & 0.9 & NA & NA & 0.8 & NA & $\mathrm{NA}$ \\
\hline W9 & $09 / 27 / 95$ & 0.7 & NA & NA & 0.9 & $\mathrm{NA}$ & $\mathrm{NA}$ \\
\hline W9 & $10 / 25 / 95$ & 0.9 & NA & NA & 0.9 & NA & NA \\
\hline W9 & $11 / 29 / 95$ & 2.4 & NA & NA & 2.2 & NA & NA \\
\hline
\end{tabular}

\begin{tabular}{|c|c|c|c|c|c|c|c|}
\hline \multirow{2}{*}{$\begin{array}{c}\text { Sampling } \\
\text { Location }\end{array}$} & $\begin{array}{c}\text { Sampling } \\
\text { Date }\end{array}$ & $\begin{array}{c}\text { Ternald Site Results } \\
\text { Uranium } \\
\text { (pCi/L) }\end{array}$ & $\begin{array}{c}\text { Ra-226 } \\
\text { (pCi/L) }\end{array}$ & $\begin{array}{c}\text { Ra-228 } \\
\text { (pCi/L) }\end{array}$ & $\begin{array}{c}\text { Total } \\
\text { Uranium } \\
\text { (pCi/L) }\end{array}$ & $\begin{array}{c}\text { Ra-226 } \\
\text { (pCi/L) }\end{array}$ & $\begin{array}{c}\text { Ra-228 } \\
\text { (pCi/L) }\end{array}$ \\
\hline W10 & $02 / 22 / 95$ & 1.5 & NA & NA & 1.3 & $<$ MDC & $<$ MDC \\
\hline W10 & $03 / 29 / 95$ & 1.6 & NA & NA & 2.4 & $<$ MDC & 1.4 \\
\hline W10-DD & $01 / 25 / 95$ & 601 & NA & NA & 359 & $<$ MDC & 3.70 \\
\hline W10-DD & $02 / 22 / 95$ & 338 & NA & NA & 230 & $<$ MDC & $<$ MDC \\
\hline W10-DD & $03 / 29 / 95$ & 480 & NA & NA & 406 & $<$ MDC & $<$ MDC \\
\hline W10-DD & $04 / 26 / 95$ & 243 & NA & NA & 228 & NA & NA \\
\hline W10-DD & $05 / 24 / 95$ & 351 & NA & NA & 354 & NA & NA \\
\hline W10-DD & $06 / 28 / 95$ & 878 & NA & NA & 865 & NA & NA \\
\hline W10-DD & $07 / 26 / 95$ & 547 & NA & NA & 512 & NA & NA \\
\hline W10-DD & $08 / 23 / 95$ & 811 & NA & NA & 777 & NA & NA \\
\hline W10-DD & $10 / 25 / 95$ & 628 & NA & NA & 622 & NA & NA \\
\hline W10-DD & $11 / 29 / 95$ & 642 & NA & NA & 615 & NA & NA \\
\hline W10-DD & $12 / 27 / 95$ & 426 & NA & NA & 385 & NA & NA \\
\hline W10-DS & $01 / 25 / 95$ & 14 & NA & NA & 14 & $<$ MDC & $<$ MDC \\
\hline W10-DS & $02 / 22 / 95$ & 24 & NA & NA & 23 & $<$ MDC & $<$ MDC \\
\hline W10-DS & $03 / 29 / 95$ & 36 & NA & NA & 34 & $<$ MDC & 1.40 \\
\hline W10-DS & $04 / 26 / 95$ & 6.1 & NA & NA & 6.1 & $<$ MDC & $<$ MDC \\
\hline W10-DS & $05 / 24 / 95$ & 4.6 & NA & NA & 5.4 & $<$ MDC & $<$ MDC \\
\hline W10-DS & $12 / 27 / 95$ & 11 & NA & NA & 11 & NA & NA \\
\hline W10-US & $02 / 22 / 95$ & 2.1 & NA & NA & 1.0 & $<$ MDC & $<$ MDC \\
\hline W10-US & $03 / 29 / 95$ & 1.7 & NA & NA & 2.2 & $<$ MDC & $<$ MDC \\
\hline W11 & $02 / 22 / 95$ & 4.3 & NA & NA & 3.2 & $<$ MDC & $<$ MDC \\
\hline W11 & $03 / 29 / 95$ & 9.5 & NA & NA & 9.2 & $<$ MDC & $<$ MDC \\
\hline W11 & $04 / 26 / 95$ & 3.7 & NA & NA & 3.3 & NA & NA \\
\hline W11 & $05 / 24 / 95$ & 2.8 & NA & NA & 2.8 & NA & NA \\
\hline W11 & $12 / 27 / 95$ & 5.1 & NA & NA & 4.7 & NA & NA \\
\hline
\end{tabular}

(a) See Figure 35 for locations

(b) To obtain Bq/L, multiply pCi/L by 0.037

NA Not Analyzed

$<$ MDC Less than the Minimum Detectable Concentration 
Table 30: Fernald Site - OEPA Sampling Comparison, 1995

Surface Water Sampling for Uranium and Radium

\begin{tabular}{|c|c|c|c|c|c|}
\hline \multirow{2}{*}{$\begin{array}{c}\text { Sampling } \\
\text { Location(a) }\end{array}$} & Sampling & \multicolumn{2}{|c|}{$\begin{array}{c}\text { Fernald Site Results (pCi/L) } \\
\text { Date }\end{array}$} & Uranium & \multicolumn{2}{c|}{ OEPA Results (pCi/L)(b) } \\
\hline $1 \mathrm{~A}$ & $6-7-95$ & 0.95 & 0.61 & 1.49 & 1.10 \\
\hline 2 & $6-7-95$ & 1.42 & 0.89 & 1.79 & 1.86 \\
\hline 4 & $6-7-95$ & 1.22 & 0.69 & 1.55 & 1.37 \\
\hline 8 & $6-7-95$ & 1.08 & 0.60 & 1.80 & 1.08 \\
\hline 9 & $6-7-95$ & 0.68 & 0.52 & 1.23 & 0.92 \\
\hline 10 & $6-7-95$ & 4.93 & 0.74 & 9.20 & 1.75 \\
\hline 11 & $6-7-95$ & 0.95 & 0.56 & 1.25 & 1.05 \\
\hline
\end{tabular}

Sediment Sampling for Thorium

\begin{tabular}{|c|c|c|c|c|c|c|c|}
\hline \multirow{2}{*}{$\begin{array}{c}\text { Sampling } \\
\text { Location(a) }\end{array}$} & \multirow{2}{*}{$\begin{array}{l}\text { Sampling } \\
\text { Date }\end{array}$} & \multicolumn{3}{|c|}{ Fernald Results (pCi/g) } & \multicolumn{3}{|c|}{ OEPA Results $(\mathrm{pCi} / \mathrm{g})(\mathrm{b})$} \\
\hline & & $228 \mathrm{Th}$ & ${ }^{230} \mathrm{Th}$ & 232Th & 228Th & $230 \mathrm{Th}$ & 232Th \\
\hline $1 \mathrm{~A}$ & $6-7-95$ & 0.43 & 0.63 & 0.30 & 0.87 & 0.97 & 0.75 \\
\hline 2 & $6-7-95$ & 0.69 & 0.85 & 0.55 & 0.78 & 1.13 & 0.71 \\
\hline 4 & $6-7-95$ & 0.51 & 0.73 & 0.39 & 0.85 & 1.02 & 0.62 \\
\hline 8 & $6-7-95$ & 0.50 & 0.49 & 0.35 & 1.05 & 1.15 & 0.89 \\
\hline 9 & $6-7-95$ & 0.48 & 0.33 & 0.15 & 0.43 & 0.75 & 0.37 \\
\hline 10 & 6-7-95 & 0.61 & 1.00 & 0.44 & 1.10 & 1.66 & 0.72 \\
\hline 11 & $6-7-95$ & 0.39 & 0.39 & 0.26 & 0.52 & 0.79 & 0.49 \\
\hline
\end{tabular}

Grass Sampling for Uranium

\begin{tabular}{|c|c|c|c|}
\hline $\begin{array}{c}\text { Sampling } \\
\text { Location(a) }\end{array}$ & $\begin{array}{c}\text { Sampling } \\
\text { Date }\end{array}$ & \multicolumn{2}{|c|}{$\begin{array}{c}\text { Concentration (pCi/g) } \\
\text { Fernald Site }\end{array}$} \\
\hline 2 & $7-7-95$ & 0.095 & 0.061 \\
\hline 3 & $7-7-95$ & 0.026 & 0.009 \\
\hline 8 & $7-7-95$ & 0.601 & 0.043 \\
\hline 18 & $7-12-95$ & 0.002 & 0.001 \\
\hline 24 & $7-12-95$ & 0.021 & 0.006 \\
\hline 25 & $7-12-95$ & 0.101 & 0.043 \\
\hline 33 & $7-7-95$ & 0.074 & 0.001 \\
\hline
\end{tabular}

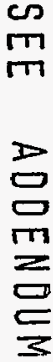


P. Table 30: Fernald Site - OEPA Sampling Comparison, 1995

Soil Sampling for Uranium

\begin{tabular}{|c|c|c|c|}
\hline $\begin{array}{c}\text { Sampling } \\
\text { Location(a) }\end{array}$ & $\begin{array}{c}\text { Sampling } \\
\text { Date }\end{array}$ & \multicolumn{2}{|c|}{$\begin{array}{c}\text { Concentration (pCi/g) } \\
\text { Fernald Site }\end{array}$} \\
\hline 2 & $7-7-95$ & 7.4 & 8.4 \\
\hline 3 & $7-7-95$ & 64.9 & 58.7 \\
\hline 8 & $7-7-95$ & 23.0 & 20.9 \\
\hline 18 & $7-12-95$ & 2.3 & 2.2 \\
\hline 24 & $7-12-95$ & 5.9 & 5.1 \\
\hline 25 & $7-12-95$ & 4.7 & 3.8 \\
\hline 33 & $7-7-95$ & 2.2 & 2.2 \\
\hline
\end{tabular}

(a) See Figures 27 (page 89), 35 (page 105), and 37 (page108) for locations.

(b) OEPA results have not been verified. 
I abıe 3U: rernald Site - OEPA Sampling Comparison, 1995

\begin{tabular}{|c|c|c|c|c|c|}
\hline \multicolumn{6}{|c|}{ Sediment Sampling for Uranium and Radium } \\
\hline \multirow[b]{2}{*}{$\begin{array}{l}\text { Sampling } \\
\text { Location }\end{array}$} & \multirow[b]{2}{*}{ Sampling Date } & \multicolumn{2}{|c|}{ Fernald Site Results } & \multicolumn{2}{|c|}{ OEPA Results } \\
\hline & & $\begin{array}{l}\text { Total } \\
\text { Uranium } \\
\text { (pCi/g) }\end{array}$ & $\begin{array}{r}\mathrm{Ra}-226 \\
(\mathrm{pCi} / \mathrm{g})\end{array}$ & $\begin{array}{c}\text { Total } \\
\text { Uranium } \\
\text { (pCi/L) }\end{array}$ & $\begin{array}{r}\mathrm{Ra}-226 \\
(\mathrm{pCi} / \mathrm{g})\end{array}$ \\
\hline $1 \mathrm{~A}$ & $06 / 07 / 95$ & 0.95 & 0.61 & 1.49 & 1.10 \\
\hline 2 & $06 / 07 / 95$ & 1.42 & 0.89 & 1.79 & 1.86 \\
\hline 4 & $06 / 07 / 95$ & 1.22 & 0.69 & 1.55 & 1.37 \\
\hline 8 & $06 / 07 / 95$ & 1.08 & 0.60 & 1.80 & 1.08 \\
\hline 9 & $06 / 07 / 95$ & 0.68 & 0.52 & 1.23 & 0.92 \\
\hline 10 & $06 / 07 / 95$ & 4.93 & 0.74 & 9.20 & 1.75 \\
\hline 11 & $06 / 07 / 95$ & 0.95 & 0.56 & 1.25 & 1.05 \\
\hline
\end{tabular}

\begin{tabular}{|c|c|c|c|c|c|c|c|}
\hline \multirow[b]{2}{*}{$\begin{array}{l}\text { Sampling } \\
\text { Location }\end{array}$} & \multirow[b]{2}{*}{ Sampling Date } & \multicolumn{3}{|c|}{ Fernald Site Results } & \multicolumn{3}{|c|}{ OEPA Results } \\
\hline & & $\begin{array}{c}\text { Th-228 } \\
(\mathrm{pCi} / \mathrm{g})\end{array}$ & $\begin{array}{c}\text { Th-230 } \\
(\mathrm{pCi} / \mathrm{g})\end{array}$ & $\begin{array}{c}\text { Th-232 } \\
(\mathrm{pCi} / \mathrm{g})\end{array}$ & $\begin{array}{c}\text { Th-228 } \\
(\mathrm{pCi} / \mathrm{g})\end{array}$ & $\begin{array}{c}\text { Th-230 } \\
\text { (pCilg) }\end{array}$ & $\begin{array}{l}\text { Th-232 } \\
\text { (pCi/g) }\end{array}$ \\
\hline $1 \mathrm{~A}$ & $06 / 07 / 95$ & 0.43 & 0.63 & 0.30 & 0.87 & 0.97 & 0.75 \\
\hline 2 & $06 / 07 / 95$ & 0.69 & 0.85 & 0.55 & 0.78 & 1.13 & 0.71 \\
\hline 4 & $06 / 07 / 95$ & 0.51 & 0.73 & 0.39 & 0.85 & 1.02 & 0.62 \\
\hline 8 & $06 / 07 / 95$ & 0.50 & 0.49 & 0.35 & 1.05 & 1.15 & 0.89 \\
\hline 9 & $06 / 07 / 95$ & 0.48 & 0.33 & 0.15 & 0.43 & 0.75 & 0.37 \\
\hline 10 & $06 / 07 / 95$ & 0.61 & 1.00 & 0.44 & 1.10 & 1.66 & 0.72 \\
\hline 11 & $06 / 07 / 95$ & 0.39 & 0.39 & 0.26 & 0.52 & 0.79 & 0.49 \\
\hline
\end{tabular}

Grass Sampling for Uranium
\begin{tabular}{|c|c|c|c|}
\hline $\begin{array}{c}\text { Sampling } \\
\text { Location }\end{array}$ & Sampling Date & $\begin{array}{c}\text { Fernald Site Results } \\
\text { Total Uranium (pCi/g) }\end{array}$ & $\begin{array}{c}\text { OEPA Results } \\
\text { Total Uranium (pCi/g) }\end{array}$ \\
\hline 2 & $07 / 07 / 95$ & 0.095 & 0.061 \\
\hline 3 & $07 / 07 / 95$ & 0.026 & 0.009 \\
\hline 8 & $07 / 07 / 95$ & 0.601 & 0.043 \\
\hline 18 & $07 / 12 / 95$ & 0.002 & 0.001 \\
\hline 24 & $07 / 12 / 95$ & 0.021 & 0.006 \\
\hline 25 & $07 / 12 / 95$ & 0.101 & 0.043 \\
\hline 33 & $07 / 07 / 95$ & 0.074 & 0.001 \\
\hline
\end{tabular}

Soil Sampling for Uranium
\begin{tabular}{|c|c|c|c|}
\hline $\begin{array}{c}\text { Sampling } \\
\text { Location }\end{array}$ & Sampling Date & $\begin{array}{c}\text { Fernald Silte Results } \\
\text { Total Uranium (pCi/g) }\end{array}$ & $\begin{array}{c}\text { OEPA Results } \\
\text { Total Uranium (pCi/ǵ) }\end{array}$ \\
\hline 2 & $07 / 07 / 95$ & 7.4 & 8.4 \\
\hline 3 & $07 / 07 / 95$ & 64.9 & 58.7 \\
\hline 8 & $07 / 07 / 95$ & 23.0 & 20.9 \\
\hline 18 & $07 / 12 / 95$ & 2.3 & 2.2 \\
\hline 24 & $07 / 12 / 95$ & 5.9 & 5.1 \\
\hline 25 & $07 / 12 / 95$ & 4.7 & 3.8 \\
\hline 33 & $07 / 07 / 95$ & 2.2 & 2.2 \\
\hline
\end{tabular}

(a) See figures 27 (page 89), 35 (page 105), and 37 (page 108) for locations

(b) OEPA results have not been verified 


\section{Chemical Release Information for $\mathbf{1 9 9 5}$}

Among the information presented in the SER for the Fernald site are estimates on both radiological and nonradiological emissions to the environment. The information in this appendix includes chemical release estimates from the Superfund Amendments and Reauthorization Act of 1986 (SARA) 313 report for 1995 and a summary of emissions from the Boiler Plant during 1995. This summary includes the chemical name, type, and quantity of release, major release sources, and the basis of estimate.

To estimate releases, the Fernald site used a method that followed guidelines defined by SARA 313 . These estimates do not reflect actual measured emissions. Rather, the Fernald site estimated releases through material balance calculation, monitoring data, or engineering calculations.

In cases where quantitative monitoring data, inventory estimates, or emission factors were not readily available, release estimates were based on best engineering judgments. Information obtained from air permits, rate of operation, quantities used, and known treatment efficiencies were used to estimate quantities released into the environment. Typically, assumptions based on best engineering judgment were required in order to perform the calculations when all variables were not known.

Calculations for Boiler Plant emissions were based on published AP-42 emission factors and coal use and analysis records for the Fernald site during 1995.

The SARA 313 chemicals included in this appendix are a summary of the SARA Title III, Section 313 Report, required by SARA legislation. This legislation requires facilities to report any listed chemical manufactured or processed the previous year in excess of 25,000 pounds, or otherwise used in excess of 10,000 pounds. This report is submitted to USEPA and OEPA each year on July 1 for the previous calendar year and contains chemicals on USEPA's toxic substance list. 


\section{Fernald Site Chemical Release Information for 1995}

Section One: Summary of SARA 313 Report

\begin{tabular}{|l|l|c|l|l}
\hline $\begin{array}{c}\text { Chemical } \\
\text { Name }\end{array}$ & \multicolumn{1}{c|}{$\begin{array}{c}\text { Type } \\
\text { of Release }\end{array}$} & $\begin{array}{c}\text { Quantity } \\
\text { Released }(\mathrm{lb} / \mathrm{kg})\end{array}$ & \multicolumn{1}{|c|}{$\begin{array}{c}\text { Release } \\
\text { Sources }\end{array}$} & \multicolumn{1}{c|}{$\begin{array}{c}\text { Basis } \\
\text { of Estimate }\end{array}$} \\
\hline Methanol & Air: Fugitive & $339 / 154$ & $\begin{array}{l}\text { Chemical } \\
\text { Processing Aid } \\
\text { Chemical } \\
\text { Processing Aid }\end{array}$ & $\begin{array}{l}\begin{array}{l}\text { Published } \\
\text { Emission Factors } \\
\text { Published } \\
\text { Emission Factors }\end{array} \\
\end{array}$ \\
& Air: Point source & $141 / 64$ & $\begin{array}{l}\text { Chemical } \\
\text { Processing Aid }\end{array}$ & $\begin{array}{l}\text { Best Engineering } \\
\text { Judgment }\end{array}$ \\
\hline
\end{tabular}

Section Two: Boiler Plant Emissions

\begin{tabular}{|l|l|c|l|l}
\hline \multicolumn{1}{|c|}{$\begin{array}{c}\text { Chemical } \\
\text { Name }\end{array}$} & \multicolumn{1}{|c|}{$\begin{array}{c}\text { Type } \\
\text { of Release }\end{array}$} & $\begin{array}{c}\text { Quantity } \\
\text { Released (lb/kg) }\end{array}$ & \multicolumn{1}{|c|}{$\begin{array}{c}\text { Major Release } \\
\text { Sources }\end{array}$} & \multicolumn{1}{c}{$\begin{array}{c}\text { Basis } \\
\text { of Estimate }\end{array}$} \\
\hline Particulates & $\begin{array}{l}\text { Air: } \\
\text { stack emissions }\end{array}$ & $31,000 / 14,000$ & $\begin{array}{l}\text { Fossil Fuels } \\
\text { Combustion }\end{array}$ & Stack Testing \\
\hline Sulfur Dioxide & $\begin{array}{l}\text { Air: } \\
\text { stack emissions }\end{array}$ & $657,000 / 298,000$ & $\begin{array}{l}\text { Fossil Fuels } \\
\text { Combustion }\end{array}$ & Fuel Samples \\
\hline Nitrogen Oxide & $\begin{array}{l}\text { Air: } \\
\text { stack emissions }\end{array}$ & $288,000 / 131,000$ & $\begin{array}{l}\text { Fossil Fuels } \\
\text { Combustion }\end{array}$ & $\begin{array}{l}\text { AP-42 Emission } \\
\text { Factors }\end{array}$ \\
\hline Carbon Monoxide & $\begin{array}{l}\text { Air: } \\
\text { stack emissions }\end{array}$ & $105,000 / 48,000$ & $\begin{array}{l}\text { Fossil Fuels } \\
\text { Combustion }\end{array}$ & $\begin{array}{l}\text { AP-42 Emission } \\
\text { Factors }\end{array}$ \\
\hline $\begin{array}{l}\text { Non-methane } \\
\text { Volatile Organic } \\
\text { Compounds }\end{array}$ & $\begin{array}{l}\text { Air: } \\
\text { stack emissions }\end{array}$ & $1,263 / 573$ & $\begin{array}{l}\text { Fossil Fuels } \\
\text { Combustion }\end{array}$ & $\begin{array}{l}\text { AP-42 Emission } \\
\text { Factors }\end{array}$ \\
\hline
\end{tabular}

\section{Fernald Site Source Reduction Information for 1995}

\section{Section One: Summary of SARA 313 Report}

There were no source reductions completed in 1995. 


\begin{tabular}{|c|c|c|c|}
\hline APPEN & Remov & tion Summary & \\
\hline Number & Title & Scope & Status \\
\hline 1 & $\begin{array}{l}\text { Contaminated Water } \\
\text { Under FEMP Buildings }\end{array}$ & $\begin{array}{l}\text { Pump water from extraction wells underneath Plants } 2 / 3,6,8 \\
\text { and } 9 \text {; treat extracted water for removal of volatile organic } \\
\text { chemicals and uranium before discharge }\end{array}$ & $\begin{array}{l}\text { Plant } 6 \text { operational; Plant } 8 \\
\text { operational; Plants } 2 / 3 \& 9 \\
\text { temporarily disabled }\end{array}$ \\
\hline 2 & $\begin{array}{l}\text { Waste Pit Area Run-off } \\
\text { Control }\end{array}$ & $\begin{array}{l}\text { Collect and treat contaminated storm water run-off from the } \\
\text { waste pit area }\end{array}$ & $\begin{array}{l}\text { Operational 7/30/92; (per } 9 / 95 \\
\text { CA/FFCAFFA-CARE Monthly } \\
\text { Progress Report, DOE-0073-96, } \\
\text { 10/18/95); operation ongoing }\end{array}$ \\
\hline \multirow[t]{10}{*}{3} & \multirow[t]{10}{*}{$\begin{array}{l}\text { South Groundwater } \\
\text { Contamination Plume }\end{array}$} & $\begin{array}{l}\text { Part } 1 \text { - Install new alternate water supply and transfer to } \\
\text { industrial user }\end{array}$ & $\begin{array}{l}\text { Operational } 12 / 7 / 92 ; \text { operation } \\
\text { ongoing }\end{array}$ \\
\hline & & Part 2 - Pump and discharge groundwater from South Plume & $\begin{array}{l}\text { Operational 8/27/93; RW } 5 \text { off-line } \\
\text { indefinitely }\end{array}$ \\
\hline & & $\begin{array}{l}\text { Part } 3 \text { - Install and operate two Interim Advanced Waste Water } \\
\text { Treatment (IAWWT) systems--Storm Waer Retention Basin } \\
\text { (SWRB) \& Biodenitrification Effluent Treatment System (BDN- } \\
\text { ETS) to reduce uranium contaminant loading to the Great } \\
\text { Miami River }\end{array}$ & Operational $7 / 30 / 92$ \\
\hline & & $\begin{array}{l}\text { Part 4- Conduct groundwater monitoring and institutional } \\
\text { controls by sampling private and existing RI/FS wells in the } \\
\text { South Plume area and instal homeowner ion exchange } \\
\text { treatment units. }\end{array}$ & Ongoing \\
\hline & & $\begin{array}{l}\text { Part } 5 \text { - Conduct groundwater modeling and geochemical } \\
\text { investigation to define the extent of the groundwater plume } \\
\text { contaminated with uranium. }\end{array}$ & Completed 2/25/94 \\
\hline & & $\begin{array}{l}\text { OU2-Dispute Resolution Supplemental Project: Provide for } \\
\text { partial treatment of the South Plume discharge to further } \\
\text { reduce uranium loading to the Great Miami River: }\end{array}$ & $\begin{array}{l}\text { Operational 3/31/94; operation } \\
\text { ongoing }\end{array}$ \\
\hline & & $\begin{array}{l}\text { Step } 1 \text { - An additional IAWWT - South Plume Interim } \\
\text { Treatment Project (SPIT) - to treat } 200 \text { gpm of South Plume } \\
\text { flow; }\end{array}$ & \\
\hline & & $\begin{array}{l}\text { Step 2- Use off-peak capacity of Phase IAWWT for South } \\
\text { Plume flow when no storm water requires treatment; }\end{array}$ & \\
\hline & & Step 3 - Eliminate low uranium concentration streams; & \\
\hline & & $\begin{array}{l}\text { Step } 4 \text { - Extend operating life/increase capacity of the SWRB } \\
\text { IAWWT. }\end{array}$ & \\
\hline 4 & K-65 Silos $1 \& 2$ & $\begin{array}{l}\text { Install bentonite cap to reduce radon emissions; provide } \\
\text { follow-on monitoring }\end{array}$ & $\begin{array}{l}\text { Cap completed } 11 / 28 / 91 \\
\text { monitoring ongoing }\end{array}$ \\
\hline 5 & $\begin{array}{l}\text { K-65 Silos Decant Sump } \\
\text { Tank Water }\end{array}$ & Remove liquid from K-65 decant sump tank & $\begin{array}{l}\text { Initial removal of liquid completed } \\
4 / 16 / 91 \text {; periodic removal ongoing }\end{array}$ \\
\hline
\end{tabular}




\begin{tabular}{|c|c|c|c|}
\hline Number & Title & Scope & Status \\
\hline 6 & $\begin{array}{l}\text { Waste Pit } 6 \text { Residues/ } \\
\text { Exposed Materials }\end{array}$ & $\begin{array}{l}\text { Eliminate potential airborne contamination by resubmerging } \\
\text { exposed pit material }\end{array}$ & Completed $12 / 19 / 90$ \\
\hline 7 & $\begin{array}{l}\text { Plant } 1 \text { Pad Continuing } \\
\text { Release }\end{array}$ & $\begin{array}{l}\text { Stage } 1 \text { - Implement run-on/off } \\
\text { control measures } \\
\text { Stage } 2 \text { - Install new pad } \\
\text { Stage } 3 \text { - Upgrade exisitng Plant } 1 \text { Storage Pad }\end{array}$ & $\begin{array}{l}\text { Completed } 1 / 17 / 92 \\
\text { Completed } 12 / 4 / 92 \\
\text { Completed } 9 / 30 / 94 \\
\end{array}$ \\
\hline 8 & $\begin{array}{l}\text { Inactive Flyash Pile and } \\
\text { Other Southfield Area } \\
\text { Isolation Actions }\end{array}$ & Install plastic chain-link barrier and post warning signs & Completed 12/23/91 \\
\hline 9 & $\begin{array}{l}\text { Removal of Waste } \\
\text { Inventories }\end{array}$ & Disposition of low-level wast offsite & Ongoing \\
\hline 10 & Active Flyash Pile Controls & $\begin{array}{l}\text { Phase } 1 \text { - Complete interim surface stabilization } \\
\text { Phase II - Complete active flyash pile controls }\end{array}$ & $\begin{array}{l}\text { Completed 6/29/92 } \\
\text { Completed 6/29/92; maintenance } \\
\text { ongoing }\end{array}$ \\
\hline 11 & $\begin{array}{l}\text { Waste Pit } 5 \text { - Experimental } \\
\text { Treatment Facility }\end{array}$ & $\begin{array}{l}\text { Remove contents, structure, and filter material; backfill and cap } \\
\text { with clay cover }\end{array}$ & Completed 3/20/92 \\
\hline 12 & Safe Shutdown & $\begin{array}{l}\text { Remove uranium and other material from former prcoessing } \\
\text { equipment and ship material and equipment off-site }\end{array}$ & Ongoing \\
\hline 13 & Plant 1 Ore Silos & Dismantle 14 ore silos and their support structures & Completed 11/18/94 \\
\hline 14 & $\begin{array}{l}\text { Contaminated Soils } \\
\text { Adjacent to Sewage } \\
\text { Treatment Plant Incinerator }\end{array}$ & $\begin{array}{l}\text { Isolate or remove and dispose of contaminated soils from the } \\
\text { vicinity of the sewage treatment plant }\end{array}$ & Completed 11/8/94 \\
\hline 15 & Scrap Metal Piles & $\begin{array}{l}\text { Phase I - Disposition LLW ferrous/non-ferrous scrap metal } \\
\text { Phase II - Containerize scrap copper } \\
\text { Phase IIB - Disposition scrap copper }\end{array}$ & Completed 9/29/92 \\
\hline 16 & $\begin{array}{l}\text { Collect Uncontrolled } \\
\text { Production Area Runoff } \\
\text { (Northeast) }\end{array}$ & $\begin{array}{l}\text { Collect storm water run-off from the northeast perimeter of the } \\
\text { former production area in the Storm Water Retention Basin }\end{array}$ & Completed 8/20/93 \\
\hline 17 & $\begin{array}{l}\text { Improved Storage of Soil } \\
\text { and Debris }\end{array}$ & $\begin{array}{l}\text { Improve storage of exisiting and future generated soils and } \\
\text { debris }\end{array}$ & Ongoing \\
\hline 18 & $\begin{array}{l}\text { Control Exposed Material } \\
\text { in Waste Pit } 5\end{array}$ & $\begin{array}{l}\text { Eliminate potential airborne contamination by resubmerging } \\
\text { exposed waste pit material }\end{array}$ & Completed 12/16/92 \\
\hline 19 & Plant 7 Dismantling & $\begin{array}{l}\text { Decontaminate, dismantle and dispose of Plant } 7 \text { structure } \\
\text { including building crane and Building } 4 \mathrm{C} \text { (Plant } 4 \text { maintenance } \\
\text { building) }\end{array}$ & Completed $11 / 18 / 94$ \\
\hline
\end{tabular}




\begin{tabular}{|c|c|c|c|}
\hline Number & Title & Scope & Status \\
\hline 20 & $\begin{array}{l}\text { Stabilization of UNH } \\
\text { Inventories }\end{array}$ & $\begin{array}{l}\text { Neutralize, filter and package UNH (uranyl nitrate hexahydrate } \\
\text { inventory) }\end{array}$ & Completed \\
\hline 21 & $\begin{array}{l}\text { Expedited Silo } 3 \text { Dust } \\
\text { Collector }\end{array}$ & $\begin{array}{l}\text { Mitigate the potential release of hazardous waste material by } \\
\text { covering and sealing dust collector hopper, removing dust } \\
\text { collector, and capping and covering obvious release pathways }\end{array}$ & Completed $1 / 8 / 92$ \\
\hline 22 & $\begin{array}{l}\text { Waste Pits Area } \\
\text { Containment Improvement }\end{array}$ & $\begin{array}{l}\text { Stabilize south berm of Pit } 4 \text {; regrade drainage ditches along } \\
\text { Pits } 3,4,5 \text {, and } 6 \text {; and resurface road between Pits } 3,4,5 \text {, } \\
\text { and } 6\end{array}$ & Completed $7 / 30 / 93$ \\
\hline 23 & Inactive Flyash Pile & $\begin{array}{l}\text { Conduct field investigation to identify locations requiring } \\
\text { material removal }\end{array}$ & Completed $4 / 30 / 92$ \\
\hline 24 & $\begin{array}{l}\text { Pilot Plant Sump } \\
\text { (HWMU \#22) }\end{array}$ & Remove liquid and slude from the sump & Completed 10/15/93 \\
\hline 25 & $\begin{array}{l}\text { Nitric Acid Rail Tank Car } \\
\text { and Area (HWMU \#22) }\end{array}$ & $\begin{array}{l}\text { Remove residual contents from tank car and decontaminate } \\
\text { and dispose of tank car }\end{array}$ & Completed 10/11/93 \\
\hline 26 & Asbestos Removals & $\begin{array}{l}\text { Mitigate the potential for contamination by and migration of } \\
\text { asbestos fib ers }\end{array}$ & Ongoing \\
\hline 27 & $\begin{array}{l}\text { Management of } \\
\text { Contaminated Structures } \\
\text { at the FEMP }\end{array}$ & $\begin{array}{l}\text { Identify alternatives for managing contaminated structures in an } \\
\text { Engineering Evaluation/Cost Analysis (EE/CA) }\end{array}$ & $\begin{array}{l}\text { Final EE/CA approved } 6 / 16 / 93 \\
\text { superseded by OU3 Interim } \\
\text { Remedial Action }\end{array}$ \\
\hline 28 & $\begin{array}{l}\text { Contamination at the } \\
\text { Fire Training Facility } \\
(\text { HWMU \#1) }\end{array}$ & $\begin{array}{l}\text { Remove, decontaminate, dispose, treat or store contaminated } \\
\text { structures, equipment, and soil from the former Fire Training } \\
\text { Facility }\end{array}$ & Ongoing \\
\hline 29 & $\begin{array}{l}\text { Stabilization of Paddys } \\
\text { Run Bank near Inactive } \\
\text { Flyash Pile }\end{array}$ & $\begin{array}{l}\text { Mitigate the threat of erosion induced slope failure and } \\
\text { discharge of flyash to Paddys Run } \\
\text { Phase I - Place } 220 \mathrm{ft} \text {. rock berm along Paddys Run } \\
\text { immediately adjacent to the Inactive Flyash Pile } \\
\text { Phase II - Design and implement permanent action for same }\end{array}$ & $\begin{array}{l}\text { Completed 5/4/93 } \\
\text { Completed 9/9/93; maintenance } \\
\text { ongoing }\end{array}$ \\
\hline 30 & KC-2 Warehouse Well \# 67) & & Cancelled \\
\hline 31 & $\begin{array}{l}\text { Seepage Control at the } \\
\text { South Field and Inactive } \\
\text { Flyash Pile }\end{array}$ & $\begin{array}{l}\text { Minimize future groundwater contamination by intercepting } \\
\text { contaminated seeps that drain from the South Field and } \\
\text { Inactive Flyash Pile and infiltrate to the Great Miami Aquifer }\end{array}$ & $\begin{array}{l}\text { Ongoing; completion scheduled for } \\
10 / 17 / 95\end{array}$ \\
\hline
\end{tabular}




\section{References}

1 General Environmental Protection Program, U.S. Department of Energy Order 5400.1, November 9, 1988.

1a Fernald Citizens Task Force, Interim Report: Preliminary Recommendations on Future Use and Cleanup levels for the Fernald Site, November 1994.

2 Facemire, C.F., S.I. Guttman, D. R. Osborne, and R.H. Sperger, Biological and Ecological Site Characterization of the Feed Materials Production Center, Miami University, Oxford, Ohio, 1990.

3 Feed Materials Production Center, Fernald, Ohio, Remedial Investigation Report for Operable Unit 4 Task 6 Report, Final Draft, U.S. Department of Energy, Oak Ridge Operations Office, October 1990.

4 GeoTrans, Inc., Preliminary Characterization of the Groundwater Flow System Near the Feed Materials Production Center, Great Miami River Valley-Fill Aquifer, Fernald, Ohio, September 1985.

5 Speiker, A. M., Groundwater Hydrology and the Geology of the Lower Great Miami River Valley, Ohio, USGS Professional Paper 605-A, 1968.

6 Dames and Moore, Groundwater Study Task C Report, June 1985.

$7 \quad$ FMPC Environmental Monitoring Section, 1990 Groundwater Monitoring Annual Report for the Fernald Site, Draft, November 1991.

8 Rozelle, James L., Facsimile to T. R. Neyer, April 20, 1994.

9 Radiation Protection for the Public and the Environment, U.S. Department of Energy Order 5400.5, February 8, 1990.

10 International Commission on Radiological Protection, Annals of the ICRP, Recommendations of the International Commission on Radiological Protection, ICRP Publication Nos. 26/30, Parts 1, 2, 3, Pergamon Press, Oxford, NY, 1977, 1979, 1980, and 1981.

11 National Emission Standards for Hazardous Air Pollutants - Subpart H National Emission Standards for Emissions of Radionuclides other than Radon from DOE Facilities, Code of Federal Regulations, Title 40, Parts 61.93 and 61.94, Vol. 50, No. 25, February 1985.

12 National Interim Primary Drinking Water Regulations - Subpart B - Maximum Contaminant Levels, Code of Federal Regulations, Title 40, Part 141, July 1, 1984.

13 Maynard and Hodge, 1949, as referenced in FR, Volume 56, No. 138, p. 33077, July 18, 1991. 
14 National Council on Radiation Protection and Measurements, Ionizing Radiation Exposure of the Population of the United States, NCRP-93, 1987.

15 Upton, Arthur C., The Biological Effects of Low-Level Ionizing Radiation, Scientific American, pp. 41-49, February 1982.

16 The American Nuclear Society and the International Atomic Energy Agency, Radiation - A Fact of Life, 1979.

17 Eisenbud, Merril, Environmental Radioactivity, 2nd ed., New York, Academic Press, 1973.

18 Murray, Raymond L., Understanding Radioactive Waste, 2nd ed., Columbus, Ohio, Battelle Press, 1983.

19 Kingman, Sharon, A Lot of Fuss About a Few Millisieverts, New Scientist, May $15,1986$.

20 Marx, Jean L., Lower Radiation Effect Found, Science, September 9, 1988.

21 National Research Council, Health Effects of Exposure to Low Levels of Ionizing Radiation, BEIR V, National Academy Press, 1990.

U.S. Department of Energy, Office of Environmental Guidance, "Hazardous" Terminology, January 1991.

U.S. Department of Energy, CERCLA/RCRA Background Soil Study, Fernald Environmental Management Project, Final, March 1993.

U.S. Environmental Protection Agency, Method for Estimating Fugitive Particulate Emissions from Hazardous Waste Sites, EPA/600/2-87/066, PB87-232203, Cincinnati, Ohio, August 1987.

Myrich, T. E., B. A. Berven, and F. F. Haywood, Determination of Concentrations of Selected Radionuclides in Surface Soil in the U.S., Health Physics, 453, 1983.

26 Radiological Effluent Monitoring and Environmental Surveillance, Code of Federal Regulations, Title 10, Part 834, Draft, January 10, 1991.

27 Ohio Environmental Protection Agency, Measurements and Procedures, Laws and Regulations, Regulation No. 3745-1804, November 1984.

28 Miller, Michael C., Electrofishing Survey of the Great Miami River, August 20 23, Draft, University of Cincinnati Department of Biological Sciences, November 1992 .

29 Bardo, R. W., Great Miami River Fish Data for 1995, M:EH:EHA:(AIM):960060, March 22, 1996.

30 Fernald Environmental Restoration Management Corporation, 1994 RCRA Annual Report, Volume 1, March 1995. 
31 Hem, John, D., Study and Interpretation of the Chemical Characteristics of Natural Water, Geological Survey Water Supply Paper 1473, 1982.

32 Varchol, B. D., Statistical Evaluation of Homeowner Wells, WMCO:R:(EM): 90-0296, June 7, 1990.

33 Secondary Maximum Contaminant Levels, Code of Federal Regulations, Title 40, Part 143, July 1, 1988.

34 Controls for Environmental Pollution, Inc., Drinking Water Handbook, Santa Fe, New Mexico, 1988.

35 National Secondary Drinking Water Regulations, Code of Federal Regulations, Title 40, Part 143, July 1991.

36 Miller, Charles W., ed., Models and Parameters for Environmental Radiological Assessments, Report DOE/TIC - 11468, Oak Ridge National Laboratory, 1984.

37 U.S. Department of Energy, Internal Dose Conversion Factors for Calculation of Dose to the Public, DOE/EH-0071, July 1988.

38 National Council on Radiation Protection and Measurements, Evaluation of Occupational and Environmental Exposures to Radon and Radon Daughters in the United States, NCRP-78, 1984.

39 International Commission on Radiological Protection, Limits for Intakes of Radionuclides by Workers, ICRP-30, July 1978.

40 International Commission on Radiological Protection, Recommendations of the ICRP, ICRP-26, January 1977.

41 U.S. Department of Energy, 1994, Characterization of Background Water Quality For Streams and Groundwater, Draft Final, Fernald Environmental Management Project, DOE, Fernald Field Office, Cincinnati, $O H$.

42 U.S. Department of Energy, 1995, Remedial Investigation Report for Operable Unit 5, Final, Fernald Environmental Management Project, DOE, Fernald Area Office, Cincinnati, $\mathrm{OH}$.

43 Reid, D. F., W. M. Sackett, and R. F. Spalding, Uranium and Radium In Livestock Feed Supplements, Health Physics, Vol. 32, pp. 535-540, 1977.

44 Linsalata, P., R. Morse, H. Ford, M. Eisenbud, E. Penna Franca, M. B. de Castro, N. Lobao, I. Sachett, M. Carlos, Transport Pathways of Th, U, Ra, and La from Soil to Cattle Tissues, J. of Environmental Radioactivity, Vol. 10, pp. 115-140, 1989.

45 U.S. Department of Energy, Feasibility Study Report for Operable Unit 5, June 1995.

46 U.S. Department of Energy, Operable Unit 5 Predesign Investigation and Site Selection Report, July 1995. 


\section{Glossary}

Activity the rate of disintegration, expressed as disintegrations per second (Becquerels) or in units of Curies (one Curie $=3.7 \times 10^{10}$ Becquerels).

ALARA a phrase and acronym (As Low As Reasonably Achievable) used to describe an approach to radiation exposure and emissions control or management whereby the exposures and resulting doses to the public are maintained as far below the specified limits as economic, technical, and practical considerations will permit.

Aliquot the fraction of a field sample taken for complete processing through an analytical procedure (a "laboratory sample" of a field sample).

Alpha Particle

Anion

Aquifer

Background Radiation

Backlog

Beta Particle

Billet

Biological Indicator

Blank

Calibration

Confidence Coefficient type of particulate radiation (identical to the nucleus of the helium atom) consisting of two protons and two neutrons.

the negatively charged atom in an ionic compound.

a body of rock that is sufficiently permeable to conduct groundwater and to yield economically significant quantities of water to wells and springs.

the radiation in the natural environment, including cosmic rays and radiation from the naturally radioactive elements, both outside and inside the bodies of humans and animals, and fallout from nuclear weapons tests.

onsite waste awaiting permitted treatment, storage, or disposal options.

type of particulate radiation emitted from the nucleus of an atom that has a mass and charge equal in magnitude to that of the electron.

machined ingots. During production times at the site, these billets were shipped to other DOE sites for use.

organisms that reveal the presence of pollution in an ecosystem. For instance, algal blooms indicate organically or nutrient-enriched waters.

a sample of the carrying agent (gas, liquid, or solid) normally used to selectively measure a material of interest that is subjected to the usual analytical procedures process to establish a baseline or background value. This value is then used to adjust or correct the routine analytical results.

the adjustment of the system and the determination of system accuracy using known sources and instrument measurements. Adjustment of flow, temperature, humidity, or pressure gauges and the determination of system accuracy should be conducted using standard operating procedures and sources that are traceable to the National Institute of Standards and Technology.

the chance or probability, usually expressed as a percentage, that a confidence interval includes some defined parameter of a population. The confidence coefficients usually associated with confidence intervals are $90 \%$, $95 \%$, and $99 \%$. For a given sample size, the width of the confidence interval increases as the confidence coefficient increases. 


\section{Confidence Interval}

\section{Conservative Estimate}

Contamination

Critical Organ

Critical Pathway

Curie (Ci) and

Becquerel (Bq)

Daughter

Decay

Derby

Derived

Concentration Guideline

Dose

Drum Equivalent

Effluent Monitoring

Enrichment

Environmental

Detection Limit

Exposure Pathway a value interval that has a designated probability (the confidence coefficient) of including some defined parameter of the population.

used frequently in environmental monitoring and dose calculation, it is based on assumptions about an exposure situation that should result in the highest estimate of a dose.

a condition in which any substance or material is somewhere it is not supposed to be.

the human organ or tissue receiving the largest fraction of a specified dose limit.

the specific route of transfer of radionuclides from one environmental component to another that results in the greatest fraction of an applicable dose limit to a population group or an individual's whole body, organ, or tissue.

are units of radioactivity that measure the rate of spontaneous, energyemitting transformations in the nuclei of atoms.

One Curie equals 37 billion transformations per second. One Becquerel equals one transformation per second. One Curie ( 37 billion $\mathrm{Bq}$ ) of natural uranium is equivalent to a mass of about 1,500 kilograms ( 3,300 pounds).

a nucleus that results from radioactive decay; also, progeny.

the disintegration process of an atomic nucleus.

the main product of the former site processing of uranium metal.

the concentration of a radionuclide in air or water that, under conditions of continuous exposure for one year by one exposure mode (for example, drinking water or breathing the air) that would result in either an effective dose equivalent of $0.1 \mathrm{rem}(1 \mathrm{mSv})$ or a dose equivalent of $5 \mathrm{rem}(50 \mathrm{mSv})$ to any tissue, including skin and the lens of the eye.

quantity of radiation absorbed in tissue.

the number of 55-gallon drums that it would take to contain a given volume of waste.

the collection and analysis of samples or measurements of liquid, gaseous, or airborne effluents for the purpose of characterizing and quantifying contaminants and process stream characteristics, assessing radiation exposures to members of the public, and demonstrating compliance with applicable standards.

a process to increase the percentage of a desired isotope such as uranium-235.

the lowest concentration at which a radionuclide in an environmental medium can be unambiguously distinguished for a given confidence level using a particular combination of sampling and measurement procedures, sample volume, analytical detection limit, and processing procedure.

a route by which materials could travel between the point of release and the point of delivery of a radiation or chemical dose to a person. 
Fission

Flux Rate

Fugitive Dust

Gamma Ray

Glacial Till

Half-life

Hydrology

ICRP

Ingot

In situ

Ionization

Isotope

Less than Detectable

Lithology

Lower Limit of Detection

Minimum Detection Level

Mixed Wastes

Monitor the splitting of a heavy nucleus into two approximately equal parts, accompanied by the release of large amounts of energy and generally one or more neutrons.

a measurement of the emission rate of radon.

dust that did not flow through a production stack. This includes materials such as dust from the waste storage areas and administration areas, and dust that originated from construction activities.

type of electromagnetic radiation of discreet energy emitted during radioactive decay of many radioactive elements.

the mix of clay, silt, sand, gravel, and boulders deposited by the glaciers.

the length of time for half the atoms of a given radioactive substance to decay.

the study of the properties, distribution, and circulation of water through the local environment.

International Commission on Radiological Protection is an organization founded in 1928. Its function is to recommend international standards for radiation protection.

remelted derbies and uranium scrap-metal from the former site production process. They varied in weight, size, and shape according to how they were used at this and other DOE sites.

in the original location.

removal of electrons from an atom, such as by means of interaction with radiation.

atoms with the same atomic number but different mass number. Isotopes usually have the same chemical properties, but could have very different radiological properties (such as half-life and type of radiation emitted).

refers to a measurement or calculated concentration that is not statistically different from the associated background or control value at a selected confidence level.

the study, classification, and mapping of rocks and rock formations.

the smallest amount of a contaminant that can be distinguished in a sample by a given measurement procedure at a given confidence level.

the minimum amount of the constituent or species of interest that can be observed by an analytical instrument and distinguished from background and instrument noise with a specified degree of probability.

hazardous waste that has been contaminated with low-level radioactive materials.

1) to measure certain constituents or parameters in an effluent stream continuously or at a frequency that permits a representative estimate of the amount over a specified interval of time;

2) the instrument or device used in monitoring. 
NCRP National Council on Radiation Protection and Measurements chartered by Congress in 1914 and charged with developing radiation protection standards.

Nuclide a general term applicable to all atomic forms of the elements, including isotopes.

Null Allele

an inactive group of genes.

Occurrence any sudden release or sustained deviation from a regulated or planned performance of an operation that has environmental protection and compliance significance.

Onsite refers to the area within the boundaries of a facility or site that is or can be controlled with respect to access by the general public.

Opacity how much light is blocked by particulates present in stack emissions.

Operable Unit a discrete action that comprises an incremental step toward comprehensively addressing site problems. Operable units may address geographical portions of a site, specific site problems, or initial phases of an action performed over time, or any actions that are concurrent but located in different parts of the site.

Overburden the soil, rock, and other naturally occurring material overlying the bedrock.

Overpacking the act of placing a deteriorating drum inside a new, larger drum to prevent further deterioration or the possible release of contaminants during storage.

Parent Material a radionuclide that produces a specific "daughter" product either directly or as a later result of radioactive decay or disintegration.

Person-rem a collective dose to a population group. For example, a dose of one rem to ten people results in a collective dose of ten person-rem.

Plate Out a thermal, electrical, chemical, or mechanical action that results in a loss of material by deposition on surfaces.

Point Source the single defined point (origin) of a release such as a stack, vent, pipe, or other discernable conveyance.

Positive Interference during sampling analysis, this produces a result that indicates the presence of a radionuclide when, in fact, there is very little or no presence of this radionuclide in the sample.

Potable Water water that is suitable for consumptive purposes.

Radioactive Emissions releases of radioactive materials to the environment.

Radioactive Material refers to any material or combination of materials that spontaneously emits ionizing radiation.

Radioisotope a radioactive isotope.

Radionuclide refers to a radioactive nuclide. There are several hundred known radionuclides, both artificially produced and naturally occurring; radionuclides are characterized by the number of neutrons and protons in an atom's nucleus and their characteristic decay processes.

Random Samples

samples that are obtained in such a manner that all items or members of the lot, or population, have an equal chance of being selected in the sample. 
Remedial Action an action that is consistent with the final remedy following a formal examination of the nature and extent of the release, or threat of release, assessment of the risk, and selections of the final remedy based on an evaluation of possible alternatives (RI/FS process).

Removal Action any necessary action to abate an immediate threat to health and the environment, including actions necessary to monitor, assess, or evaluate the threat.

Representative Sample

Roentgen Equivalent Man (rem) and Sievert $(\mathrm{Sv})$

Roentgen (R) and Coulombs per kilogram $(\mathrm{C} / \mathrm{kg})$

Sample 1) a subset or group of objects selected from a larger set, called the population;

2) an extracted portion of a subset of an effluent stream or environmental medium.

Sampling the extraction of a prescribed portion of an effluent stream or of an environmental medium for purposes of inspection and/or analysis.

Scintillation Cell

Sensitivity

Site Characterization

Spiked Sample

Terrace Remnants

Thermoluminescent Dosimeter

Tolerance Limits

Transuranic

Wetland produces a light pulse when struck by an alpha particle and is able to be counted.

the minimum amount of a radionuclide or other material of interest that can repeatedly be detected by an instrument, system, or procedure.

designed to provide the information needed to identify site hazards and to select worker protection methods.

a normal sample of material (gas, liquid, or solid) to which a known amount of some substance of interest is added. Spiked samples are used to check on the performance of a routine analysis or the recovery efficiency of an analytical method.

land that stands higher than its surroundings due to erosion.

used to monitor the amount of radiation to which it has been exposed.

a particular type of confidence limit used frequently in quality control work, where the limits apply to a percentage of the individual values of the population.

an element with an atomic number greater than uranium.

areas covered or saturated with water for enough time to support water-loving vegetation. Typical wetlands include swamps, marshes, and bogs. 